NBSIR 80-2029

\title{
The Thermochemical Properties of the Uranium-Halogen Containing Compounds
}

Vivian B. Parker

Center for Thermodynamics and Molecuiar Science

Chemical Thermodynamics Division

National Bureau of Standards

U.S. Department of Commerce

Washington, D.C. 20234

July 1980

interim Report

\section{Prepared for}

International Atomic Energy Agency and

100

fice of Standard Reference Data, NBS

.456 
$\ldots$

THE THERMOCHEMICAL PROPERTIES OF

THE URANIUM-HALOGEN CONTAINING

COMPOUNDS

Vivian B. Parker

DATE DUE

Center for Thermodynamics and Molecular Science Chemical Thermodynamics Division National Bureau of Standards U.S. Department of Commerce Washington, D.C. 20234

July 1980

Interim Report

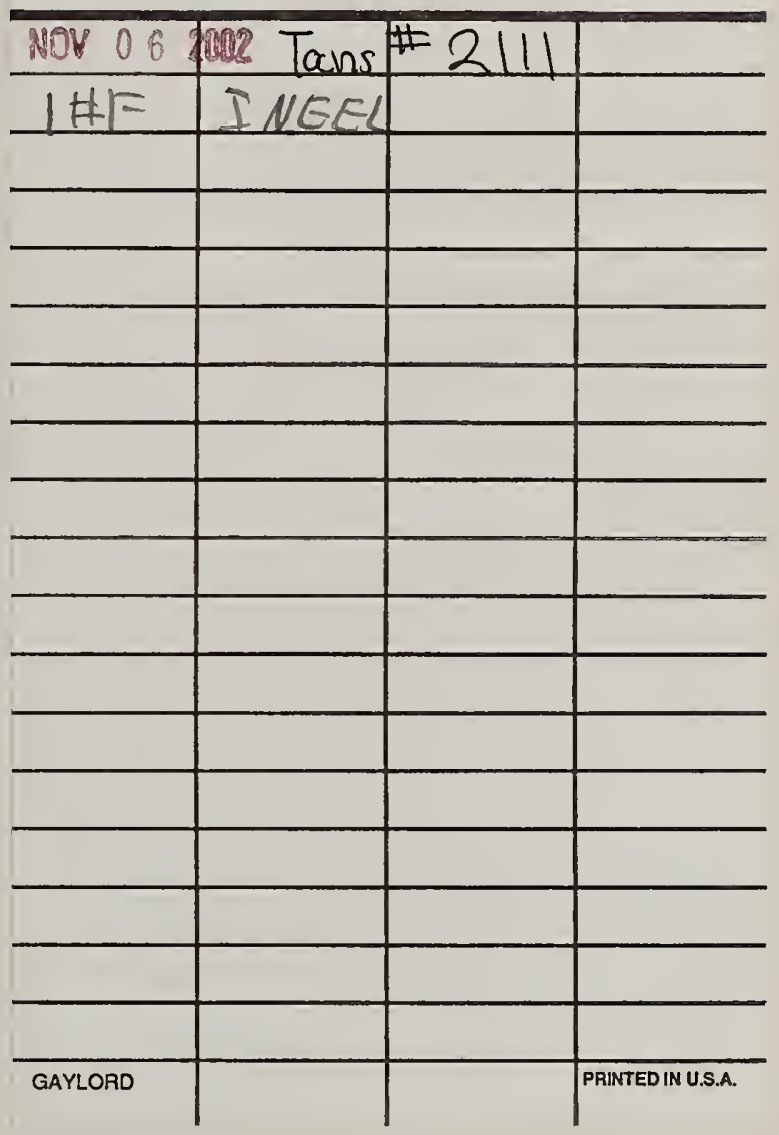

Prepared for

International Atomic Energy Agency and

Office of Standard Reference Data, NBS

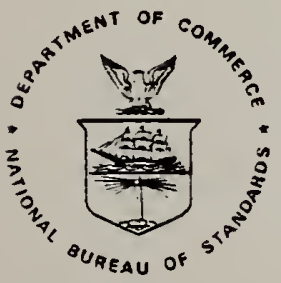

U.S. DEPARTMENT OF COMMERCE, Philip M. Klutznick, Secretary Luther H. Hodges, Jr., Deputy Secretary Jordan J. Baruch, Assistant Secretary for Productivity. Technology, and Innovation NATIONAL BUREAU OF STANDARDS, Ernest Ambler, Director 
सर्य 
The Thermochemical Properties of the Uranium-Halogen Containing Compounds

Vivian B. Parker 



\section{Table of Contents}

I. General Description

1. Introduction .. . . . . . . . . . . . 2

2. Explanation of the Contents of the Text and Tables

2.1 Conventions Regarding Pure Substāues . . . . . 3

2.2 Convention Regarding Solutions for the Tabulated Values

2.3 Convention Regarding Solutions for Reactions in the Text . . . . . . . . . . . . . . .

2.4 Chemical Formulae and Physical States for the Tabulated Values . . . . . . . . . . . .

2.5 Definition of Symbols for Thermochemical Properties for the Tabulated Values . . . . . . . . . 7

3. Unit of Energy and Fundamental Constants . . . . 7

4. Internal Consistency of the Tables....... 8

4.I The Use of Auxiliary Data . . . . . . . . 8

4.2 Uncertainties ... . . . . . . . . . 10

4.3 Relationship to Other Tables of The modynamic Properties.................. 10

5. Arrangement of the Tables . . . . . . . 12

II. The Evaluation and Analysis of the Thermochemistry of the Uranium-Halogen Containing Compounds

1. The Evaluation Procedure . . . . . . . . 18

2. The Analysis of the Data... . . . . . . 20

3. The Evaluations of the Uranium-Halogen Containing Compounds . . . . . . . . . . . . . . . 
3.100 U-X (X=F, $\mathrm{Cl}, \mathrm{Br}$ or $\mathrm{I})$ Compounds with/without $\mathrm{O}$. .

3.101 U-F Compounds . . . . . . . . . 21

3.102 U-F-O Compounds . . . . . . . . 59

3.103 U-C1 Compounds . . . . . . . . . . 69

$3.104 \mathrm{U}-\mathrm{Cl}-\mathrm{O}$ Compounds . . . . . . . . 86

3.105 U-Cl-F Compounds . . . . . . . 105

3.106 U-Br Compounds . . . . . . . . . 106

3.107 U-Br-O Compounds . . . . . . . . 113

3.108 U-Br-C1 Compounds . . . . . . . . . 119

3.109 U-I Compounds . . . . . . . . . . 121

$3.110 \mathrm{U}-\mathrm{I}-\mathrm{C} 1-\mathrm{Br}$ Compounds . . . . . . . . 126

$3.200 \mathrm{U}-\mathrm{X}$ Compounds with $\mathrm{N}$. . . . . . . 128

$3.201 \mathrm{U}-\mathrm{NH}_{4}-\mathrm{F}-\mathrm{O}$ Compounds . . . . . . . . 128

3.300 U-X Compounds and the Alkali Metals, M $(\mathrm{M}=\mathrm{Li}, \mathrm{Na}, \mathrm{K}, \mathrm{Rb}$, or $\mathrm{Cs}) . . . . . . .131$

$3.301 \mathrm{U}-\mathrm{F}-\mathrm{M}$ Compounds . . . . . . . . . 131

3.302 U-F-O-M Compounds . . . . . . . . . 133

3.303 U-C1-M Compounds . . . . . . . . 135

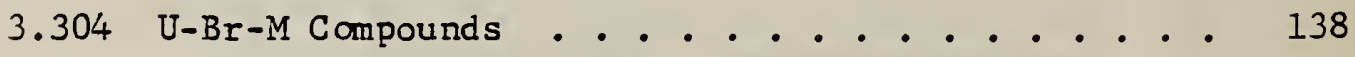

III. Tables of Values for $\Delta H f^{\circ}, \Delta G f^{\circ}, S^{\circ}, C_{p}{ }^{\circ}$, and $H-H_{0}$ at $298.15 \mathrm{~K}$ and $\Delta \mathrm{Hf}^{\circ}$ at $0 \mathrm{~K}$ for the Uranium-Halogen Containing

Compounds . . . . . . . . . . . . . . . . 139

IV. Bibliography . . . . . . . . . . . . 149

V. Appendix . . . . . . . . . . . . 160 
The Thermochemical Properties of the

Uranium-Halogen Containing Compounds

\section{Vivian B. Parker}

Abstract

A detailed analysis and evaluation of the thermochemistry of 142 uranium-halogen containing compounds is presented, and a tabular summary of the thermochemical properties is given. The properties given, where data are available, are the enthalpy of formation, $\Delta \mathrm{Hf}^{\circ}$, Gibbs energy of formation, $\Delta G f^{\circ}$, entropy, $\mathrm{S}^{\circ}$, heat capacity, $\mathrm{C}_{\mathrm{p}}{ }^{\circ}$, and the enthalpy difference, $\left(\mathrm{H}-\mathrm{H}_{0}\right)$, all at temperature $298.15 \mathrm{~K}$, and the enthalpy of formation at $0 \mathrm{~K}, \Delta \mathrm{Hf}^{\circ}{ }_{0}{ }^{\cdot}$ The values are consistent with the CODATA Key Values for Thermodynamics.

The analys is of the uranium-halogen containing compounds includes some vapor pressure equations and $C_{p}$ equations. Some thermal functions which are not readily available in the accessible open literature are presented in the Appendix for compounds that required their use.

The tabular summary of $\Delta H f^{\circ}, \Delta G f^{\circ}$, etc. includes the values for those uranium compounds which were necessary for this evaluation.

Keywords: Data evaluation; enthalpy; entropy; Gibbs energy; heat capacity; thermochemical tables; uranium-halogen containing compounds. 


\section{General Description}

\section{Introduction}

This report presents a detailed analysis and evaluation of the thermochemistry of 142 uranium-halogen containing compounds and a tabular summary of $\Delta H^{\circ}{ }^{\prime} s, \Delta G f^{\circ} s, S^{\circ} s, C p^{\circ} s,\left(H-H_{0}\right)$ 's at $298 \mathrm{~K}$, $\Delta H f_{0}^{\circ}$ 's for these compounds. It is part of an independent ongoing evaluation of the thermochemistry of the actinide compounds for inclusion in the NBS Technical Note 270 Series. The interest of the IAEA in sponsoring a series on the thermochemistry of the actinides by compound class, both at low and high temperatures, has led to our participation in this effort*.

Since this IAEA review uses the CODATA (1975) recommended values for the auxiliary key compounds, a 11 compounds considered here have been evaluated on this basis and represent part of our contribution to the Halide Chapter of the IAEA sponsored series, "The Chemical Thermodynamics of Actinide Elements and Compounds".

The analysis of the uranium-halogen containing compounds includes some vapor pressure equations and $C_{p}$ equations. Some therma 1 functions which are not readily available in the accessible open literature are presented in the Appendix for compounds that required their use.

The tabular summary of $\Delta H f^{\circ}, \Delta G f^{\circ}$, etc. includes the values for those uranium compounds which were necessary for this evaluation. The sources for these values are given in 4.1 .

Users are invited to comment on the selections, correct errors and bring new measurements to our attention.

See Wagman et a1. (1977). References are listed by author and year in the bibliography (Section. IV). 
2. Explanation of the Contents of the Text and Tables

The following material provides definitions and conventions used in the tables.

\subsection{Conventions Regarding Pure Substances}

The values of the thermodynamic properties of the pure substances given in these tables are for the substances in their standard states. These standard states are defined as follows:

For a pure solid or liquid, the standard state at any temperature is the substance in the condensed phase under a pressure of one a tmosphere.

For a gas the standard state at any temperature is the hypothetical ideal gas at unit fugacity, in which state the enthalpy is that of the real gas at the same temperature and at zero pressure.

The phase of a substance is indicated in parentheses at the end of the chemical formula (see Table A).

The values of $\Delta H f^{\circ}$ and $\Delta G f^{\circ}$ given in the tables represent the change in the appropriate thermodynamic quantity when one mole of the substance in its standard state is formed, isothermally at the indicated temperature, from the elements, each in its appropriate standard reference state. The standard reference state at $298 \mathrm{~K}$ for each element except phosphorus has been chosen to be the standard state that is thermodynamically stable at $298 \mathrm{~K}$ and at one atmosphere pressure. For phosphorus the standard reference state is the crystalline white form; the more stable forms have not been well characterized 
thermochemical $1 y$. The same reference states have been maintained for the elements at $0 \mathrm{~K}$ except for the liquid elements bromine and mercury for which the reference states have been chosen as the stable crystalline forms. The standard reference states for the elements are indicated in the tables by the fact that the values of $\Delta H f^{\circ}$ and $\triangle G f^{\circ}$ are exactly zero.

The values of $S^{\circ}$ represent the virtual or "thermal" entropy of the substance in the standard state at $298.15 \mathrm{~K}$, omitting contributions from nuclear spins and isotopic mixing. Where data have been available only for a particular isotope, they have been corrected when possible to the normal isotopic composition.

\subsection{Convention Regarding Solutions for the Tabulated Values}

For all dissolved substances the composition of the solvent is indicated in parentheses following the chemical formula. Except in special cases, discussed below, the number of moles of the solvent associated with one mole of solute is stated explicitly. See Table A for the conventions used.

In some cases the concentration of the solute can not be specified. These are indicated as "AU" (aqueous, unspecified) for water solutions and by " $U$ " for non-aqueous and mixed media. In a 11 these cases the solution may be assumed to be "dilute".

The standard state for a non-dissociated solute in aqueous solution is taken as the hypothetical ideal solution of unit molality, which has been designated as "std. state, $m=1 "$. For strong electrolytes in aqueous solution the conventional standard state is the ideal 
solution of unit activity (unit mean molality). The designation "A" is used for strong electrolytes in the standard state and "AO" for undissociated species in water solution. In non-aqueous media two standard states are commonly used. For the mole fraction scale, "std. state, $x_{2}=1$ ", $x$ is added to the formula of the solvent. For the molal scale, "std. state, $m=1 "$, either $s$ or $M$ is appended to the formula.

The value of $\Delta H f^{\circ}$ for a solute in its standard state is equa 1 to the apparent molal enthalpy of formation of the substance in the infinitely dilute real solution, since the enthalpy of dilution of an ideal solution is zero. At this dilution the partial molal enthalpy is equal to the apparent molal quantity. At concentrations other than the standard state, the value of $\Delta H f^{\circ}$ represents the apparent enthalpy of the reaction of formation of the solution from the elements comprising the solute, each in its standard reference state, and the appropriate total number of moles of solvent. In this representation the value of $\Delta H f^{\circ}$ for the solvent is not required. The experimental value for a heat of dilution is obtained directly as the difference between the two values of $\Delta H f^{\circ}$ at the corresponding concentrations. At finite concentrations the partial molal enthalpy of formation differs from the apparent enthalpy.

The values of the thermodynamic properties tabulated for the individual ions in aqueous solution are based on the usual convention 
that the values of $\Delta H f^{\circ}, \Delta G f^{\circ}, S^{\circ}$ and $C_{p}{ }^{\circ}$ for $H^{+}$(aq, std. state, $m=1$ ) are zero. The properties of a neutral electrolyte in aqueous solution in the standard state are equal to the algebraic sum of these values for the appropriate kinds and numbers of individual ions assumed to constitute the molecule of the given electrolyte. For an ionic aqueous species e.g., $\mathrm{HSO}_{4}{ }^{-}$, the properties tabulated refer to that undissociated ion, i.e., they are not equal to the sum of those for its constituent ions. By adopting the above convention with respect to aqueous $\mathrm{H}^{+}$, it follows that the thermodynamic relation $\Delta G f^{\circ}=\Delta H f^{\circ}-T\left(\Delta S f^{\circ}+\pi \cdot 0.5 S^{\circ}\left(H_{2}\right)\right)$ holds for individual ionic species, with $n$ equal to the algebraic value of the charge. For neutral electrolytes the normal consistency relationship applies. See section 4 .

\subsection{Convention in the Text (Section II) for Reactions Involving Solutions}

In the text reactions involving solutions are given as the authors presented them in the literature. The discussion accompanying the reactions gives the interpretation.

\subsection{Chemical Formulae and Physical States for the Tabulated Values (Section III}

These tables were reproduced from computer printout in which only capital (upper case) letters are available. Normal one-line chemical formulae are used, with the following modifications:

- Subscripts (counts of atoms): UCL'4 $=\mathrm{UCl}_{4}$

- The apostrophe' appears after each letter in a chemical symbol that would normally be written in lower case: $U C L{ }^{\prime} B R^{\prime} 3=\mathrm{UClBr}_{3}$ 
- The centered dot, used in hydrates and minerals, is shown as a colon: UF $4: 2.5 \mathrm{H} 2 \mathrm{O}=\mathrm{UF}_{4} \cdot 2.5 \mathrm{H}_{2} \mathrm{O}$

- The physical state of the substance is appended to the chemical formula in parentheses: UCL'4(C) $=\mathrm{UCl}_{4}$, crystalline Conventions with respect to physical state are given in Table A.

\subsection{Definition of Symbols for The rmochemical Properties for the Tabulated Values (Section III)}

The headings used in the tabulated The rmochemical Values have the following meanings:

$$
\begin{aligned}
& \text { DH298 }=\Delta H f^{\circ}, \text { standard enthalpy of formation at } 298.15 \mathrm{~K} ; \\
& \text { DG298 }=\Delta G f^{\circ} \text {, standard Gibbs energy of formation at }
\end{aligned}
$$

$298.15 \mathrm{~K}$;

The others are self explanatory. All $\mathrm{H}$ and $\mathrm{G}$ relationships are in $\mathrm{kcal} / \mathrm{mol}$; all $\mathrm{S}$ and $\mathrm{C}_{\mathrm{p}}{ }^{\circ}$ relationships are in cal/mol $\cdot \mathrm{K}$.

All values refer to one mole of substance for the formula given.

\section{Unit of Energy and Fundamental Constants}

All of the energy values given in these tables are expressed in terms of the thermochemical calorie. This unit, defined as equal to 4.184 joules exactly, is used throughout the IAEA review series. Values reported in other units have been converted to calories by means of the conversion factors for molecular energy given in Table B.

Values in this report are consistent with the CODATA fundamental constants (1973).

The formula weights in the tables have been calculated from the molecular formula using the 1969 Table of Atomic Weights as given by IUPAC (1970). 
4. Internal Consistency of the Tables

The processes given in the text have been obtained from the original articles, using consistent values for all subsidiary and auxiliary quantities. The original data were corrected where possible for differences in energy units, molecular weights, temperature scales, etc. Thus we have sought to maintain a uniform scale of energies for all processes in the text and tables. In addition the final tabulated values of the properties of a substance satisfy al1 the known physical and the rmodynamic relationships among these properties. The quantities $\Delta H f^{\circ}, \triangle G f^{\circ}$, and $S^{\circ}$ at $298.15 \mathrm{~K}$ satisfy the relation:

$$
\Delta G f^{\circ}=\Delta H f^{\circ}-T \Delta S f^{\circ}
$$

to the precision given. The special case of solutions is discussed in section 2.2. Furthermore the calculated value of any thermodynamic quantity for a reaction is independent of the path chosen for the evaluation.

\subsection{The Use of Auxiliary Data}

As indicated this evaluation uses as its basis the CODATA (1975) recommended values for the auxiliary key compounds. Parker et a1. (1976) have incorporated these values into an extensive consistent set of CODATA compatible values for auxiliary values needed in this evaluation. Unless otherwise stated all values for the non-uranium containing auxiliary compounds are taken from the latter report or are consistent with it. Values for the thermal functions as a function of temperature for the auxiliary data are from JANAF (1971). 
The tables in Section III also include values for those key non-halogen containing uranium compounds that were necessary for the present evaluation. These values also maintain consistency with other IAEA chapters. In addition, the values listed for the oxides are in agreement with the independent evaluations of Parker (1975, 1976a), CODATA (1978), Rand et a1. (Part XI: The Actinide Oxides) and Glush!? (1978).

These compounds and the sources for their values are listed below. $\underline{U(c s) \text { and } U(g)}$

The tabulated values are from detting et al. (1976). $\mathrm{U}^{3+}\left(\mathrm{aq}\right.$, std. state), $\mathrm{U}^{4+}\left(\mathrm{aq}\right.$, std. state) and $\mathrm{UO}_{2}{ }^{2+}(\mathrm{a} q$, std. state)

The tabulated values are from Fuger and Detting (1976). $\underline{\mathrm{UO}_{2}(\mathrm{c})}$

$\mathrm{S}^{\circ}, \mathrm{C}_{\mathrm{p}}{ }^{\circ}$ and $\mathrm{H}-\mathrm{H}_{0}$ are obtained from the $\mathrm{C}_{\mathrm{p}}$ measurements of Westrum and Huntzicker (1971); $\Delta H \mathrm{f}^{\circ}$ is from the combustion measurements of Huber and Holley (1969).

$\underline{\mathrm{UO}_{3}(c, \gamma)}$

The $\mathrm{S}^{\circ}, \mathrm{C}_{\mathrm{p}}{ }^{\circ}$ and $\mathrm{H}-\mathrm{H}_{0}$ are from the $\mathrm{C}_{\mathrm{p}}$ measurements of Westrum (1966). The $\Delta H f^{\circ}$ is obtained from the solution calorimetry of Fitzgibbons et al. (1967) on the uranium oxides and the decomposition measurements on $\mathrm{UO}_{3}(c, \gamma)$ of Cordfunke and Aling (1965). $\underline{\mathrm{U}_{3} \mathrm{O}_{8}(\mathrm{c})}$

The $\mathrm{S}^{\circ}, \mathrm{C}_{\mathrm{P}}{ }^{\circ}$ and $\mathrm{H}-\mathrm{H}_{0}$ are obtained from Westrum and Gronvold (1959; and Girdhar and Westrum (1968), the $\Delta \mathrm{Hf}^{\circ}$ from the combustion measurements of Huber and Holley (1969). 


\subsection{Uncertainties}

Each selected value in the tabular sumary, Section III, contains the final assigned uncertainty, i.e. the estimate by the evaluator of the accuracy of the selected value. In some cases these uncertainties are calculated from (1) the uncertainties assigned to the individual reactions (usually given as $2 \sigma$ ) and the auxiliary data and (2) how well the calculated values for a property (obtained from the various reaction paths) agree within their assigned uncertainties.

Where possible or warranted the various uncertainties and the uncertainty on the selected value are also given in the individual evaluation (Section II).

In many cases, however, the final uncertainty is based on (2) and/or the evaluator's judgment, since a strictly mathematical calculation is not warranted (i.e. ( 1 ) is not applicable since no measure of precision is available, and a quantitative estimate of the uncertainty on the individual processes can not be made. In these cases no uncertainties are given in the individual evaluations (Section II)).

In both approaches, however, the final uncertainty is partly subjective.

The uncertainties for the $\mathrm{C}_{\mathrm{p}}{ }^{\circ}$ 's and $\left(\mathrm{H}-\mathrm{H}_{0}\right)$ 's appear in square brackets and are arbitrarily assigned as "10 in the last place". 4.3 Relationship to Other Tables of Thermodynamic Properties

The chemical thermodynamic properties in the present tables of halogen containing compounds may be combined with those published by 
CODATA (1975, 1978) and Parker et al. (1976) in order to calcula te the change in a property for a process. However, we recoumend against these values being combined with those in any other tabulation or with a property reported in an original research paper. In particular, we warn against indiscriminate combination with the NBS Technical Note 270 Series. Values consistent with auxiliary data in the NBS Technical Note 270 Series are available and will be included in that series.

There are several reasons for avoiding the combination of thermochemical data from more than one table. The most important is that different large-scale tables use different thermochemical properties of formation for substances that are ubiquitous in thermochemical measurements. Outstanding examples are in the comon inorganic acids and their ions. Another reason is that the groups preparing different tables may have relied on different measurements as the basis for selecting property values.

It is difficult to predict a priori how a change in one selected formation property would affect values assigned to other substances because of the way these are linked by complex networks. In general, it may be expected that the advantage of internal consistency of a table will be lost if values from several sources are combined and the experimental measurements may be reproduced poorly.

No general, simple algorithm can be suggested for overcoming this problem. If it becomes necessary to extend a table of data to substances other than those tabulated, the user is advised to consult the group that prepared the table about the procedure that is contemplated. 


\section{Arrangement of the Tables}

The compounds in the tables are entered according to the Standard Order of Arrangement, (see Figure 1), by the principle of latest position. In this scheme, a compound is listed under the element occurring latest in the list; water of hydration is neglected. Within a given element-table will be found all of the compounds of that element with elements occurring earlier in the order; the arrangement within a table follows the same ordering.

However, for the alkali metal halogen-containing compounds the arrangement is by compound class, i.e., $\mathrm{UF}_{6}, \mathrm{UO}_{2} \mathrm{~F}_{2}, \mathrm{UCl}_{4}$, and $\mathrm{UBr}_{4}$, in combination with the alkali metals. 


\section{TABLE A: Physical State Conventions for Section III}

The following conventions are used to designate the physical state of a substance. These apply to the tables in Section III. This information appears in a parenthetical expression appended to the molecular formula. Some of the explanations $\vdots=p 1 y$ a thermochemical value, particularly those for solutions. These normally are used in describing enthalpy measurements.

Basic Symbols

\section{Explanation}

Gaseous, e.g., HCL'(G) for $\mathrm{HC} \ell(\mathrm{g})$

Gaseous reference standard state for an element, e.g., $02(G S)$ for $\mathrm{O}_{2}(\mathrm{~g})$

Crystalline, e.g., $\mathrm{NH}_{4 \mathrm{CL}}$ (C) for $\mathrm{NH}_{4} \mathrm{Cl}(\mathrm{c})$

Crystalline reference standard state for an element, e.g., $R B^{\prime}(C S)$ for $R b(c)$

Liquid, e.g., $\mathrm{H} 2 \mathrm{O}(\mathrm{L})$ for $\mathrm{H}_{2} \mathrm{O}(l)$

Liquid reference standard state fo an element, e.g., $\quad B R^{\prime} 2(L S)$ for $\mathrm{Br}_{2}(l)$

Amorphous

Glassy

Hypothetical standard state of the ideal aqueous solution at unit activity. For a neutral electrolyte the value of a property is equal to the algebraic sum of the values for the ions assumed to constitute the molecule of the electrolyte, e.g. HCL $(A)=H+(A)+C L^{\prime}-(A)$. For an ionic species this notation is commonly used to refer to the undissociated ion as written. e.g., $\mathrm{HSO}-(\mathrm{A})$ 
$\underline{\text { Symbol }}$

(AO)

(AU)

\section{Explanation}

Hypothetical standard state of the ideal aqueous solution at unit activity of the undissociated (non-ionized) species, e.g., $\mathrm{HF}(\mathrm{AO}), \mathrm{HF} 2-(\mathrm{AO})$. May also be used whenever the designation (A) could be ambiguous. Note that the descriptions HSO4-(A) and HSO4-(AO) are equivalent, but that $\mathrm{HF}(\mathrm{A})$ and $\mathrm{HF}(\mathrm{AO})$ are not.

Aqueous solution of undefined, but usually dilute, concentration, e.g., XE'03(AU).

The symbols used above occasionally are modified by numbers to distinguish two substances in the same state that have the same molecular weight, as for isomers: (AU2), (C3). They are also used in combination with descriptive material, e.g. ( $\left.: H E^{\prime}\right)$, (C:AL') etc. to mean "crystalline, hexagonal, "crystalline, alpha form", etc.

\section{Special notations for substances in solutions}

The notations for the "state" of a substance in solution may combine a definition of the system, e.g. HCl in 220 moles of water, and a specification of the thermochemical property associated with it. Usually the thermochemical property is the apparent integral enthalpy or free energy of formation or an absolute entropy, i.e. the formation properties of the solvent are not included. If a partial molal property is tabulated the notation D: ("D" for "differential") occurs as the first term in the state bracket. The notations given below illustrate the differences for integral and differential (partial molal) properties, and extrapolated values. Examples are given for aqueous, mixed, and non-aqueous solvents. 
Symbol

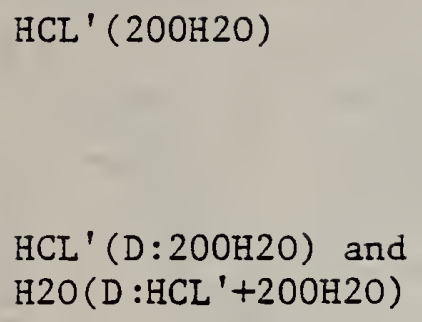

HCL' (200H20)

$\mathrm{HCL}^{\prime}(\mathrm{D}: 2 \mathrm{OOH} 2 \mathrm{O})$ and $\mathrm{H} 2 \mathrm{O}\left(\mathrm{D}: \mathrm{HCL}{ }^{\prime}+200 \mathrm{H} 20\right.$ )

UCL ' 4 (HCL ' $04+50 \mathrm{H} 20$ ) $50 \mathrm{H} 20: \mathrm{AU})$

An aqueous solution of specified composition, e.g. one mole of $\mathrm{HCl}$ in 200 moles $\mathrm{H}_{2} \mathrm{O}$. The value of $\Delta H f$ represents the apparent integral enthalpy of formation.

These represent the partial molal (enthalpy of formation of the substance in a solution of specified concentration, e.g. the partial molal enthalpy of formation of $\mathrm{HCl}$ and $\mathrm{H}_{2} \mathrm{O}$ respectively, in a solution consisting of 1 mole $\mathrm{HCl}$ and 200 moles $\mathrm{H}_{2} \mathrm{O}$.

This describes a solute dissolved in a mixed solvent, e.g. one mole of $\mathrm{UC}_{4} 4$ in a mixture of 1 mole of $\mathrm{HC}_{2} \mathrm{O}_{4}$ and 50 moles $\mathrm{H}_{2} \mathrm{O}$. The value of $\Delta H f$ represents the apparent integral enthalpy of formation of the substance, $\mathrm{UCl}_{4}$, in the medium.

This represents a solute at an unspecified but usually dilute concentration in a solvent mixture of fixed composition. 


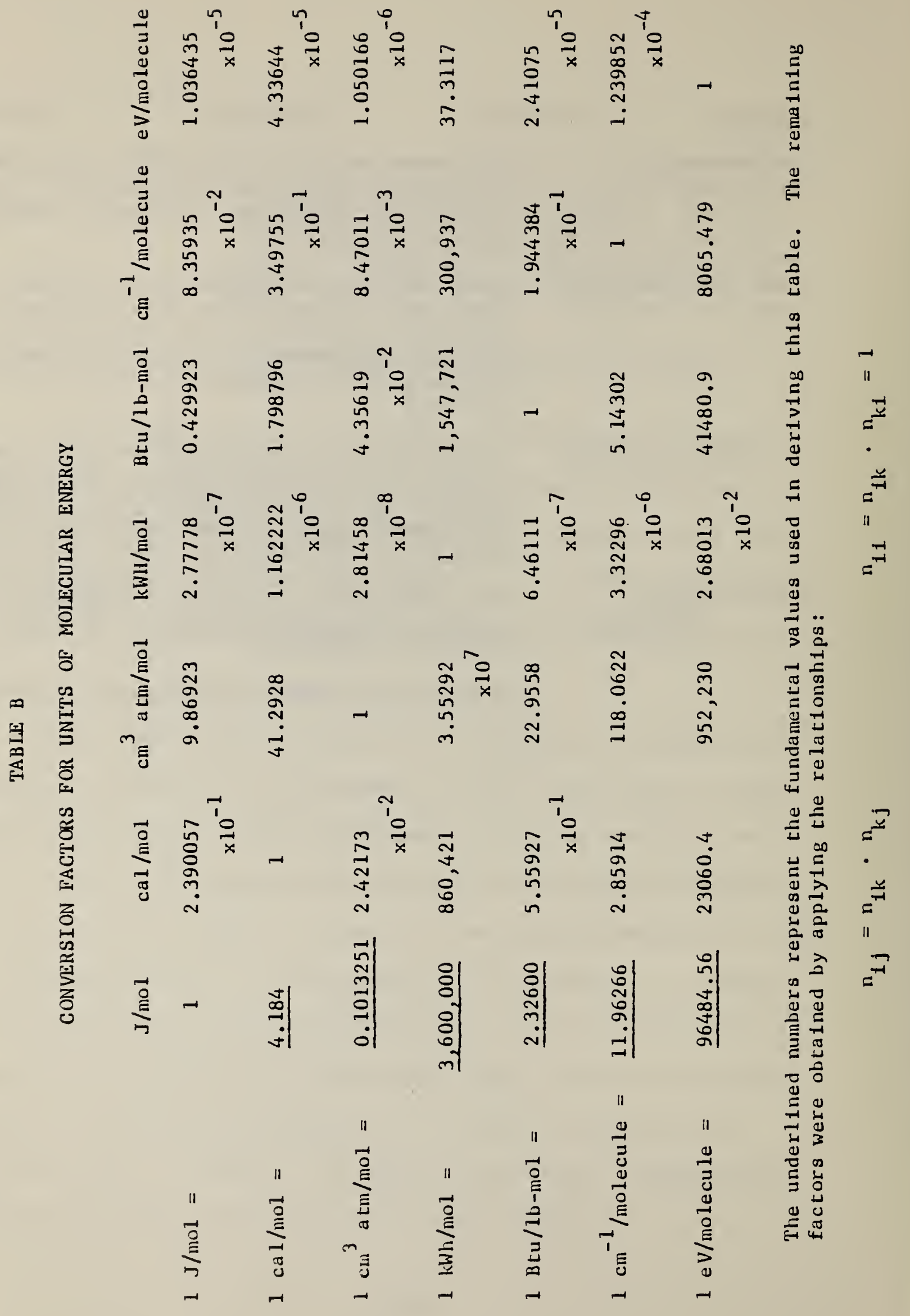


STANDARD ORDER OF ARRANGEMENT

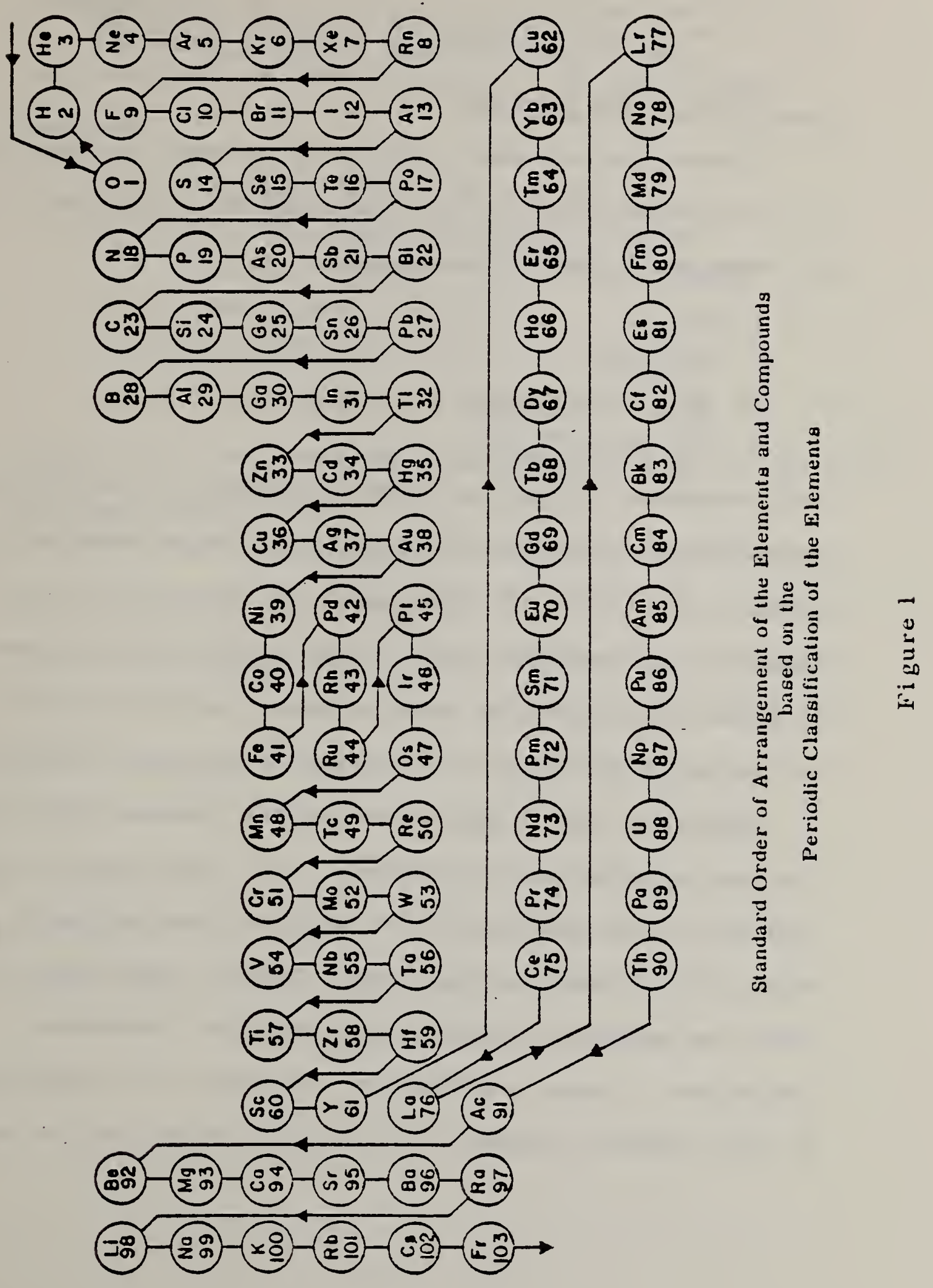


II. The Evaluation and Analysis of the Thermochemistry of the Uranium-Ha logen Containing Compounds

1. The Evaluation Procedure

Although the compounds evaluated are arranged systematically, it is recommended that the user first read the evaluations for the key compounds in the following order:

$$
\begin{aligned}
& \text { 1. } \mathrm{UCl}_{4}(\mathrm{c}) \\
& \text { 2. } \mathrm{UO}_{2} \mathrm{Cl}_{2}(\mathrm{c}) \\
& \text { 3. } \mathrm{UF}_{6}(\mathrm{c}) \text { and } \mathrm{UO}_{2} \mathrm{~F}_{2}(\mathrm{c}) \\
& \text { 4. } \mathrm{UF}_{3}(\mathrm{c}) \text { and } \mathrm{UF}_{4}(\mathrm{c})
\end{aligned}
$$

This arrangement follows the stepwise procedure of evaluating the thermochemical properties by the sequential method described by Garvin et a1. (1976). In this method, the values for the key compounds are determined first, so that a framework or network of values is developed for those compounds that are essential for the determination of the properties of many other compounds. Initially, this procedure involves the compounds whose properties can be determined independently, i.e., they involve no other compounds of the same element (in this case, uranium) and/or they depend only on known auxiliary data. Ideally, there should be definitive measurement paths between these key compounds as indications of mutual confirmation. Thereafter, the properties of other compounds dependent on these first selections are chosen. 
The halogen compounds listed above are only part of the uranium key network, which includes all of the following compounds :

1. $\mathrm{U}(\mathrm{c}), \mathrm{U}_{3} \mathrm{O}_{3}(\mathrm{c}), \mathrm{UO}_{2}(\mathrm{c})$, a nd $\mathrm{UO}_{3}(\mathrm{c}, y)$

2. $\mathrm{UCl}_{4}(\mathrm{c}), \mathrm{UO}_{2} \mathrm{Cl}_{2}(\mathrm{c})$, and $\mathrm{Un}\left(\mathrm{NO}_{3}\right)_{2} \cdot 6 \mathrm{H}_{2} \mathrm{O}(\mathrm{c})$

3. $\mathrm{U}^{4+}$ (aq, std. state) and $\mathrm{UO}_{2}{ }^{2+}$ ( $\mathrm{qq}$, std. state)

4. $U(g)$, UN (c), US (c), and UC(c)

5. $\mathrm{UF}_{6}(\mathrm{c})$ and $\mathrm{UO}_{2} \mathrm{~F}_{2}(\mathrm{c}), \mathrm{UF}_{3}(\mathrm{c})$ and $\mathrm{UF}_{4}(\mathrm{c})$

The non-halogen compounds listed above in 1,2 , and 3 , as we 11 as $U(g)$ from 4 are considered fixed auxiliary data for this evaluation (see Section I 4.1). 


\section{The Analysis of the Data}

The purpose of thermochemical data evaluation is the selection of reliable values, i.e., ones that can be used with confidence. When properly documented, an evaluation not only presents the results but alsn explains how they were obtained. This explanation is analogous to the detailed experimental section of a thermochemical measurement paper. An explanation of our evaluation is provided here to assist the user and to reduce the need for reinvestigation in the future.

The evaluator usually works with some incomplete records. There are not enough data to solve all of the problems that arise. Therefore, it is necessary to "squeeze" the maximum amount of information out of the existing data. That will become apparent in the individual evaluations that follow.

Complete thermochemical cycles, where possible, are given. The same measurements are repeatedly considered from different points of view. The work of a research group on related systems is considered in order to assess the likely accuracy for the system of immediate interest and to modify or avoid suspect reactions and paths in determining the "best" values. 
3. The Evaluations of the Uranium-Halogen Containing Compounds

$3.100 \mathrm{U}-\mathrm{X}(\mathrm{X}=\mathrm{F}, \mathrm{Cl}, \mathrm{Br}$, or $\mathrm{I})$ with/without 0

3.101 U-F Compounds

$\mathrm{UF}_{\mathrm{n}}(\mathrm{g})(\mathrm{n}=1,2,3)$

Gurvich icial. (1977) have recently published the ideal gas the modynamic functions for $\mathrm{UF}(\mathrm{g}), \mathrm{UF}_{2}(\mathrm{~g})$, and $\mathrm{UF}_{3}(\mathrm{~g})$ based on estimates for the molecular constants and frequencies. These estimates are:

Values for Molecular Constants of UF

\begin{tabular}{|c|c|c|c|c|c|c|}
\hline \multirow{2}{*}{ Molecule } & $w_{e}$ & ${ }^{\omega} e^{x} e$ & $\mathrm{~B}_{\mathrm{e}}$ & $\approx$ & $\mathrm{D}_{0} \cdot 10^{7}$ & \multirow{2}{*}{$\begin{array}{l}\text { Number of } \\
\text { Electronic } \\
\text { States }\end{array}$} \\
\hline & & & $\mathrm{cm}^{-1}$ & & & \\
\hline UF & 580 & 1.72 & 0.230 & 0.0014 & 1.5 & $\begin{array}{l}82 \text { with sta- } \\
\text { tistical weight }=2 \\
\text { and } \mathrm{T}_{\mathrm{e}} \leqq 51000 \mathrm{~cm}^{-1}\end{array}$ \\
\hline
\end{tabular}

Values for Molecular Constants of $\mathrm{UF}_{2}$ and $\mathrm{UF}_{3}$ in the Ground State

$\begin{array}{lcc} & \mathrm{UF}_{2} & \mathrm{UF}_{3} \\ \text { Symme try } & \mathrm{C}_{2 \mathrm{v}} & \mathrm{C}_{3 \mathrm{v}} \\ \sigma & 2 & 3 \\ r(\mathrm{U}-\mathrm{F}), \& & 2.00 \pm 0.05 & 2.00 \pm 0.05 \\ \langle F-\mathrm{U}-\mathrm{F}, \text { degrees } & 110^{+50} & 115^{+3} \\ \mathrm{I}_{A} \mathrm{I}_{\mathrm{B}} \mathrm{I}_{\mathrm{C}} \cdot 10^{117}, \mathrm{~g}^{3} \cdot \mathrm{cm}^{6} & 2920 \pm 2000 & 13690 \pm 2300 \\ \nu_{1}, \mathrm{~cm}^{-1} & 575 \pm 100 & 600 \pm 100 \\ \nu_{2}, \mathrm{~cm}^{-1} & 140 \pm 50 & 100 \pm 50 \\ \nu_{3}, \mathrm{~cm}^{-1} & 525 \pm 100 & 550(2) \pm 100 \\ \nu_{4}, \mathrm{~cm}^{-1} & - & 140(2) \pm 50\end{array}$

Other details are to be found in Gurvich et al. (1977). The functions are retabulated in the Appendix. They are to be considered approximate. 
Zmbov (1969) has made a mass spectrometric study of high temperasure equilibria $(1201-1313 \mathrm{k})$ of the following:

$$
\begin{aligned}
& U F_{4}(g)+\mathrm{Ca}(\mathrm{g})-\mathrm{CaF}(\mathrm{g})+\mathrm{UF}_{3}(\mathrm{~g}) \\
& U F_{4}(\mathrm{~g})+2 \mathrm{Ca}(\mathrm{g})-2 \mathrm{CaF}(\mathrm{g})+\mathrm{UF} \mathrm{F}_{2}(\mathrm{~g})
\end{aligned}
$$

From his reported $\Delta \mathrm{E}^{\prime} \mathrm{s}$ at the mean temperature and his tabulated $\mathrm{K}^{\prime} \mathrm{s}$, the following are obtained at $298 \mathrm{~K}$ :

\begin{tabular}{lcc} 
& \multicolumn{1}{c}{$\stackrel{\Delta \mathrm{H}^{\circ}}{\mathrm{kca} / \mathrm{mol}}$} \\
(1) & $23.5 \pm 4.0$ & 25.6 \\
(2) & $21.2 \pm 5.0$ & 36.0
\end{tabular}

The 2nd law value for $\Delta H^{\circ}{ }_{2}$ appears unreasonable compared to the values for $\Delta H_{1}$, so that $\Delta F_{1}=23.5 \div 4.0 \mathrm{kcal} / \mathrm{mol}$ is accepted, Iesulting in $\triangle \mathrm{BfF}^{\circ} \mathrm{UF}_{3}(\mathrm{~g})=-248 \pm 5 \mathrm{kcal} / \mathrm{mol}$. $\Delta \mathrm{HF}^{\circ} \mathrm{UF}_{2}(\mathrm{~g})$, then, may be obcained from the 3rd law $\Delta \mathrm{F}_{3}=\mathrm{H}_{2}-\mathrm{H}_{1}$ :

$$
U F_{3}(g) \div \mathrm{Ca}(\mathrm{g})-\mathrm{UF}_{2}(\mathrm{~g})+\mathrm{CaF}(\mathrm{g}) ; \Delta \mathrm{H}_{3}=10.4 \mathrm{kcal} / \mathrm{mol}
$$

The resultant $\Delta \mathrm{Ff}^{\circ} \mathrm{UF}_{2}(\mathrm{~g})=-129 \pm 7 \mathrm{kcal} / \mathrm{mol}$.

Erom a comparison of the $\Delta \mathrm{H}^{\circ}$ 's for:

$$
U F_{n}(g)-U(g)+\vec{F}(g)
$$

a reasorable estimate for $\Delta H^{\circ}$ when $\mathrm{n}=1$ is $148 \div 5 \mathrm{kcal} / \mathrm{mol}$ resulting in $\triangle F f^{\circ}$ UF $(g)=-2 \pm 5 \mathrm{kcal} / \mathrm{mol}$.

\footnotetext{
Orained using the thermal functions of $\mathrm{UF}_{4}(\mathrm{~g})$ without the addition of $3.2 \mathrm{cal} / \mathrm{mol} \cdot \mathrm{K}$ to $\mathrm{S}^{\circ} \mathrm{UR}_{4}(\mathrm{~g})$, since a similar contribution may be necessary on $\mathrm{S}^{\circ} \mathrm{UF}_{3}(\mathrm{~g})$ and $\mathrm{S}^{\circ} \mathrm{UF}_{2}(\mathrm{~g})$. Most of the contribution would cancel zesulting in third law values close to those given.
} 
$\mathrm{UF}_{3}(\mathrm{c}), \mathrm{UF}_{4}(\mathrm{c})$ and $\mathrm{UF}_{4} \cdot 2.5 \mathrm{H}_{2} \mathrm{O}(\mathrm{c})$

The entropy of $\mathrm{UF}_{3}(\mathrm{c})$ at $298 \mathrm{~K}$ has been estimated as $30.0=1.0$ cal/mol $\cdot \mathrm{K}$ in comparison with $\Delta S\left[\mathrm{PuF}_{3}(\mathrm{c})-\mathrm{PuF}_{4}(\mathrm{c})\right]^{\star}$ and $\mathrm{S}^{\circ} \mathrm{UF}_{4}(\mathrm{c})$. Krestov (1972) has estimated the $C_{p}(298-1000 \mathrm{~K})$ as:

$$
C_{p}=21.2 \div .0073 \mathrm{~T} \mathrm{cal} / \mathrm{mol} \cdot \mathrm{K} \text {. }
$$

Thermal functions have been generated from this equation and the estimated $S^{\circ}$.

Burns et al. (1960) measured the low temperature heat capacities (1.3-20 $\mathrm{k})$ of $\mathrm{UF}_{4}(\mathrm{c})$. These measurements are in agraement (in the overlapping range) with those of Osborne et al.'s (1955) measurements, 5-300 $\mathrm{k}$. The smoothed functions tabulated by Burns et al. are accepted here.

Dworkin (1972) measured the heat content of $\mathrm{UF}_{4}(c, 1)(298-1400 \mathrm{~K})$. His smoothed tabulated functions extrapolated to $1600 \mathrm{~K}$ are accepted and are represented by :

$$
\begin{aligned}
& \mathrm{H}_{\mathrm{T}}-\mathrm{H}_{298}=-9650+29.53 \mathrm{~T}+1.15 \times 10^{-3} \mathrm{~T}^{2}+2.21310^{5} \mathrm{~T}^{-1} \mathrm{cal} / \mathrm{mol}: \\
& \Delta \mathrm{H}_{\text {Iusion }}=11,230 \mathrm{cal} / \mathrm{mol} ; \Delta \mathrm{S}_{\text {Eusion }}=8.6 \mathrm{cal} / \mathrm{mol} \cdot \mathrm{K} ;(1309 \mathrm{~K}) \\
& \mathrm{H}_{\mathrm{T}}-\mathrm{H}_{298}=-9420+39.57 \mathrm{~T} \mathrm{cal} / \mathrm{mol}(1309-1400 \mathrm{~K}) \\
& \text { The earlie results of } \mathrm{King} \text { and Christensen }(1961) \text { are in fair } \\
& \text { agreement. }
\end{aligned}
$$

The measurements of Settle et al. (1963) and Hayman (1967) are in good agreement on the direct fluorination of $\mathrm{U}(\mathrm{c})$ to $\mathrm{UF}_{6}(\mathrm{c}, g)$; this lent support to the LHf ${ }^{\circ}$ 's of $U F_{3}(c)$ and $U F_{4}(c)$ ootained from

Osborne et al. (1974, 1975) reported $S^{\circ}=30.14=0.10$ and $35.18=0.10$ cal/mol $\cdot \mathrm{K}$ for $\mathrm{PuF}_{3}(\mathrm{c})$ and $\mathrm{PuF}_{4}(\mathrm{c})$, respectively. 
the fluorinations of $\mathrm{UF}_{3}(\mathrm{c})$ and $\mathrm{UF}_{4}(\mathrm{c})$ to $\mathrm{UF}_{6}(\mathrm{~g})$ by Hayman (1967) resulting in $\Delta H f^{\circ} \mathrm{UF}_{3}(\mathrm{c}) \approx-357$ and $\Delta \mathrm{Hf}^{\circ} \mathrm{UF}_{4}(\mathrm{c}) \approx-454 \mathrm{kcal} / \mathrm{mol}$. The reappraisal made here of the $\Delta \mathrm{Hf}^{\circ}{ }^{\prime}$ 's of $\mathrm{UF}_{6}(\mathrm{c})$ and $(g)$ necessitate a complete reevaluation of the $\Delta \mathrm{Af}^{\circ}$ 's $\mathrm{UF}_{3}(\mathrm{c})$ and $\mathrm{UF}_{4}(\mathrm{c})$. A tabular summary is also given (Table 1 ).

A. The Measurements on the Enthalpy of Formation of $\mathrm{UF}_{3}(\mathrm{c})$

1. Room Temperature Calorime try

Khanaev and Khripin (1970) measured the following $\Delta H^{\prime} \mathrm{s}$ (kcal/mol) at $323 \mathrm{~K}$ :

$$
\begin{aligned}
& \left(\mathrm{UO}_{2} \mathrm{Cl}_{2}+3 \mathrm{FeCl}_{2}+\mathrm{HCl}+3 / 4 \mathrm{HBF}_{4}+1 / 4 \mathrm{H}_{2} \mathrm{O}\right) \text { soln. I } \\
& \mathrm{UF}_{3}(\mathrm{c})+\left(3 \mathrm{FeCl}_{3}+3 / 4 \mathrm{H}_{3} \mathrm{BO}_{3}\right) \text { solv } ; \Delta \mathrm{H}_{1}=+34.43 \pm .12 \\
& \mathrm{UO}_{2} \mathrm{Cl}_{2}(\mathrm{c})+\left(3 \mathrm{FeCl}_{3}+3 / 4 \mathrm{H}_{3} \mathrm{BO}_{3}\right) \text { solv. } \rightarrow\left(\mathrm{UO}_{2} \mathrm{Cl}_{2}+3 \mathrm{FeCl}_{3}+\right. \\
& 3 / 4 \mathrm{H}_{3} \mathrm{BO}_{3} \text { ) soln. II; } \Delta \mathrm{H}_{2}=-8.79 \pm .03 \\
& \left(3 \mathrm{FeCl}_{2}+\mathrm{UO}_{2} \mathrm{Cl}_{2}+\mathrm{HCl}+3 / 4 \mathrm{HBF}_{4}+1 / 4 \mathrm{H}_{2} \mathrm{O}\right) \text { soln. I } \rightarrow 3 \mathrm{FeCl}_{2}(\mathrm{c})+ \\
& \left(\mathrm{UO}_{2} \mathrm{Cl}_{2}+\mathrm{HCl}+3 / 4 \mathrm{HBF}_{4}+1 / 4 \mathrm{H}_{2} \mathrm{O}\right) \text { soln. IX } \Delta_{3}=3 \times(2.642 \pm .035) \\
& \left(\mathrm{UO}_{2} \mathrm{Cl}_{2}+\mathrm{HCl}+3 / 4 \mathrm{HBF}_{4}+1 / 4 \mathrm{H}_{2} \mathrm{O}\right) \text { soln. } \mathrm{IX}+3 \mathrm{FeCl}_{3}(\mathrm{c}) \rightarrow \\
& \left(3 \mathrm{FeCl}_{3}+\mathrm{UO}_{2} \mathrm{Cl}_{2}+\mathrm{HCl}+3 / 4 \mathrm{HBF}_{4}+1 / 4 \mathrm{H}_{2} \mathrm{O}\right) \text { soln. } \mathrm{V} \\
& \Delta \mathrm{H}_{4}=3(-7.198 \pm .05) \\
& \left(\mathrm{UO}_{2} \mathrm{Cl}_{2}+3 \mathrm{FeCl}_{3}+9 / 4 \mathrm{H}_{2} \mathrm{O}+\mathrm{HCl}\right)_{\text {soln. IV }} \rightarrow 2 \mathrm{H}_{2} \mathrm{O} \text { soln. }+ \\
& \left(\mathrm{UO}_{2} \mathrm{Cl}_{2}+3 / 4 \mathrm{HBF}_{4}+3 \mathrm{FeCl}_{3}+1 / 4 \mathrm{H}_{2} \mathrm{O}+\mathrm{HCl}\right)_{\text {soln. } \mathrm{V}} \text {; } \\
& \Delta \mathrm{H}_{5}=+2.124 \pm .01
\end{aligned}
$$

Use was made of the following Khanaev (1968) measurements which they confirmed:

$$
\begin{aligned}
& \left(\mathrm{UO}_{2} \mathrm{Cl}_{2}+3 \mathrm{FeCl}_{3}+3 / 4 \mathrm{H}_{3} \mathrm{BO}_{3}\right)_{\text {soln. II }}+3 \mathrm{HF}\left(1.33 \mathrm{H}_{2} \mathrm{O}\right) \rightarrow \\
& \left(\mathrm{UO}_{2} \mathrm{Cl}_{2}+3 \mathrm{FeCl}_{3}+3 / 4 \mathrm{HBF}_{4}+9 / 4 \mathrm{H}_{2} \mathrm{O}\right)_{\text {soln. III }}+3.99 \mathrm{H}_{2} \mathrm{O}(1) \\
& \Delta_{6}=-15.18 \pm .12 \quad(6) \\
& \left(\mathrm{UO}_{2} \mathrm{Cl}_{2}+3 \mathrm{FeCl}_{3}+3 / 4 \mathrm{HBF}_{4}+9 / 4 \mathrm{H}_{2} \mathrm{O}\right)_{\text {soln. III }}+\mathrm{HCl}\left(3.91 \mathrm{H}_{2} \mathrm{O}\right) \rightarrow \\
& \left(\mathrm{UO}_{2} \mathrm{Cl}_{2}+3 \mathrm{FeCl}_{3}+3 / 4 \mathrm{HBF}_{4}+9 / 4 \mathrm{H}_{2} \mathrm{O}+\mathrm{HCl}\right)_{\text {soln. IV }}+3.91 \mathrm{H}_{2} \mathrm{O}(1) \\
& \Delta \mathrm{H}_{7}=+4.04 \pm 0.004 \quad(7)
\end{aligned}
$$


The summation, $\Delta \mathrm{H}_{1}+\Delta \mathrm{H}_{2}-\Delta \mathrm{H}_{3}-\Delta \mathrm{H}_{4}+\Delta \mathrm{H}_{5}+\Delta \mathrm{H}_{6}+\Delta \mathrm{H}_{7}=\Delta \mathrm{H}_{8}=+30.292 \pm 0.25$ corrected to $298 \mathrm{~K}$ using a $\Delta_{\mathrm{p}}=30 \mathrm{cal} / \mathrm{mol} \cdot \mathrm{K}$ results in:

$$
\begin{aligned}
\mathrm{UO}_{2} \mathrm{Cl}_{2}(\mathrm{c})+3 \mathrm{FeCl}_{2}(\mathrm{c})+3 \mathrm{HF}(\mathrm{aq}) & +\mathrm{HCl}(\mathrm{aq})-2 \mathrm{H}_{2} \mathrm{O}(1)+3 \mathrm{FeCl}_{3}(\mathrm{c}) \\
& +\mathrm{UF}_{3}(\mathrm{c}) ; \Delta \mathrm{H}_{8}=29.54 \pm 0.32 \mathrm{kcal} / \mathrm{mol}
\end{aligned}
$$

The integral values for $\triangle \mathrm{Hf} \mathrm{HCl}\left(3.92 \mathrm{H}_{2} \mathrm{O}\right)$ and $\triangle \mathrm{Hf} \mathrm{HF}\left(1.33 \mathrm{H}_{2} \mathrm{O}\right)$

are appropriate here. The resultant $\Delta \mathrm{Hf}^{\circ} \mathrm{UF}_{3}(\mathrm{c})$ is $-354.9 \pm 0.8 \mathrm{kcal} / \mathrm{mol}$. Khanaev and Khripin also measured the $\Delta \mathrm{H}_{\text {soln }}$ of $\mathrm{UCl}_{4}(\mathrm{c})$ as part of their series of measurements. The reaction follows:

$$
\begin{aligned}
\mathrm{UCl}_{4}(\mathrm{c})+ & \left(3 \mathrm{FeCl}_{3}+3 / 4 \mathrm{H}_{3} \mathrm{BO}_{3}+2 \mathrm{H}_{2} \mathrm{O}\right) \text { solv. } \rightarrow\left(\mathrm{UO}_{2} \mathrm{Cl}_{2}+2 \mathrm{FeCl}_{2}+\right. \\
& \left.\mathrm{FeCl}_{3}+3 / 4 \mathrm{H}_{3} \mathrm{BO}_{3}+4 \mathrm{HCl}\right)_{\text {soln. } \mathrm{VI}} \Delta_{9}=-18.44 \pm .02
\end{aligned}
$$

The summation from a rearrangement of the reactions, $\Delta \mathrm{H}_{9}+\Delta \mathrm{H}_{6}$ $+\Delta \mathrm{H}_{1}-3 \mathrm{x} \Delta \mathrm{H}_{7}-1 / 3 \Delta \mathrm{H}_{3}-1 / 3 \Delta \mathrm{H}_{4}=\Delta \mathrm{H}_{10}=-6.754 \pm 0.018$, corrected to $298 \mathrm{~K}$ with a $\Delta c_{p}=-48 \mathrm{cal} / \mathrm{mol} \cdot \mathrm{K}$ is :

$$
\begin{aligned}
\mathrm{FeCl}_{2}(c)+\mathrm{UCl}_{4}(c)+3 \mathrm{HF}\left(\mathrm{a}_{7}\right)-\mathrm{FeCl}_{3}(\mathrm{c}) & +\mathrm{UF}_{3}(\mathrm{c})+3 \mathrm{HCl}(\mathrm{aq}) \\
\Delta \mathrm{H}_{10} & =-5.564 \pm 0.20 \mathrm{kcal} / \mathrm{mol}
\end{aligned}
$$

so that $\Delta \mathrm{Hf}^{\circ} \mathrm{UF}_{3}(\mathrm{c})=-354.67 \pm 0.8 \mathrm{kcal} / \mathrm{mol}$. The two paths are in good agreement.

As shown in the section on $\mathrm{UO}_{2} \mathrm{Cl}_{2}(\mathrm{c})$, the $\Delta \mathrm{Hf}^{\circ} \mathrm{UO}_{2} \mathrm{Cl}_{2}(\mathrm{c})=$ $-297.0 \pm 0.5 \mathrm{kca} / \mathrm{mol}$ obtained from the above Khanaev and Khripin reactions (relating $\mathrm{UO}_{2} \mathrm{Cl}_{2}(\mathrm{c})$ to $\mathrm{UCl}_{4}(\mathrm{c})$ ) is in excellent agreement with the selected value for $\mathrm{UO}_{2} \mathrm{Cl}_{2}(\mathrm{c})$, and this lends support to the above values for $\mathrm{UF}_{3}(\mathrm{c})$. 
It is important to note that the value for $\Delta H f^{\circ} \mathrm{UF}_{4}(\mathrm{c})=-452.3 \pm 0.9$ kcal/mol derived from Khanaev (1968) [see section on $\mathrm{UF}_{4}(\mathrm{c})$ ] and the above values for $\mathrm{UF}_{3}(\mathrm{c})$ lead to:

$$
\mathrm{UF}_{3}(\mathrm{c})+1 / 2 \mathrm{~F}_{2}(\mathrm{~g}) \rightarrow \mathrm{UF}_{4}(\mathrm{c}) ; \Delta \mathrm{H}_{11}=-452.3+354.8=-97.50 \pm 0.8 \mathrm{kca} 1 / \mathrm{mol}
$$

Hayman (1967) has fluorinated $\mathrm{UF}_{3}(\mathrm{c})$ as well as $\mathrm{UF}_{4}(\mathrm{c})$ and $\mathrm{U}(\mathrm{c})$ to obtain $U F_{6}(g)$ :

$$
\begin{aligned}
& \mathrm{UF}_{3}(\mathrm{c})+3 / 2 \mathrm{~F}_{2}(\mathrm{~g}) \rightarrow \mathrm{UF}_{6}(\mathrm{~g}) ; \Delta \mathrm{H}_{12}=-153.39 \pm 0.45 \\
& \mathrm{U}(\mathrm{c})+3 \mathrm{~F}_{2}(\mathrm{~g}) \rightarrow \mathrm{UF}_{6}(\mathrm{~g}) ; \Delta \mathrm{H}_{13}=-510.47 \pm 0.64 \\
& \mathrm{UF}_{4}(\mathrm{c})+\mathrm{F}_{2}(\mathrm{~g}) \rightarrow \mathrm{UF}_{6}(\mathrm{~g}) ; \Delta \mathrm{H}_{14}=-56.82 \pm 0.17
\end{aligned}
$$

It appears that $\Delta \mathrm{H}_{13}$ is in error as shown in the discussion on $\mathrm{UF}_{6}(\mathrm{c})$ and $\mathrm{UF}_{6}(\mathrm{~g})$. If it is assumed that the error is systematic in all the measurements, then $\Delta \mathrm{Hf}^{\circ} \mathrm{UF}_{3}(\mathrm{c})=\Delta \mathrm{H}_{13}-\Delta \mathrm{H}_{12}=-357.1 \mathrm{kcal} / \mathrm{mol}$. If only $\Delta \mathrm{H}_{13}$ is in error, and $\Delta \mathrm{H}_{12}$ and $\Delta \mathrm{H}_{14}$ are reasonably correct, then using the selected $\Delta \mathrm{HF}^{\circ} \mathrm{UF}_{6}(\mathrm{~g}), \Delta \mathrm{HF}^{\circ} \mathrm{UF}_{3}(\mathrm{c})=-513.25+153.39=$ $-359.86 \pm 0.6 \mathrm{kcal} / \mathrm{mol}$ and $\Delta \mathrm{Hf}^{\circ} \mathrm{UF}_{4}(\mathrm{c})=-513.25+56.82=-456.4 \pm 0.5$ $\mathrm{kcal} / \mathrm{mol}$.

With either assumption one obtains $\Delta \mathrm{H}_{11}=-96.6 \pm 0.5 \mathrm{kcal} / \mathrm{mol}$, as contrasted with -97.5 from the Khanaev measurements.

There are other possibilities in interpreting the Hayman results: the errors in $\Delta \mathrm{H}_{12}$ and $\Delta \mathrm{H}_{14}$ are proportional to the error in $\Delta \mathrm{H}_{13}$; the errors are random and the uncertainties on $\Delta \mathrm{H}_{12}, \Delta \mathrm{H}_{13}$, and $\Delta \mathrm{H}_{14}$ are too small and the $\Delta \mathrm{HF}^{\circ}$ 's of $\mathrm{UF}_{3}(\mathrm{c})$ and $\mathrm{UF}_{4}(\mathrm{c})$ could be more positive. 


\section{High Temperature EMF Measurements Involving $\mathrm{UF}_{3}(\mathrm{c})$}

The values cited here depend on the estimated thermal functions for $\mathrm{UF}_{3}(\mathrm{c})$.

Heus and Egan (1966) and Markin et al.(1967) have measured the e.m.f. of cells involving $\mathrm{CaF}_{2}$ as a solid electrolyte.

For

$$
\mathrm{AI}(\mathrm{c})+\mathrm{UF}_{3}(\mathrm{c}) \rightarrow \mathrm{AlF}_{3}(\mathrm{c})+\mathrm{U}(\mathrm{c})
$$

the values for $\Delta G$ at $873 \mathrm{~K}$ are $4.84 \pm 1.0$ and $5.40 \pm 1.0 \mathrm{kcal} / \mathrm{mol}$, respectively, leading to $\Delta \mathrm{H}^{\circ}{ }_{15}=-3.73 \pm 1.5$ and $-3.16 \pm 1.5 \mathrm{kcal} / \mathrm{mol}$ at $298 \mathrm{~K}$ and $\Delta \mathrm{Hf}^{\circ}$ for $\mathrm{UF}_{3}(\mathrm{c})=-357.3 \pm 2.0$ and $-357.8 \pm 2.0 \mathrm{kcal} / \mathrm{mol}$, respectively.

The above relationship (15) was combined with other experimental reactions of Heus and Egan, and Markin et al. to obtain the relationship of $\mathrm{UF}_{3}(\mathrm{c})$ to $\mathrm{MgF}_{2}(\mathrm{c})$, which on the NBS Technical Note Scale, was less dependent upon their $F^{-}$(aq, std.). The following relationship is obtained which can be used with the CODATA $\triangle \mathrm{HF}^{\circ} \mathrm{MgF}_{2}(\mathrm{c})$ :

$$
4 / 3 \mathrm{U}(\mathrm{c})+2 \mathrm{MgF}_{2}(\mathrm{c})-2 \mathrm{Mg}(\mathrm{c})+4 / 3 \mathrm{UF}_{3}(\mathrm{c})
$$

and from the Heus and Egan values $\Delta G$ at $873 \mathrm{~K}=50.73$, so that $\Delta H^{\circ}{ }_{16}$ $=62.09 \pm 1.5$ and $\Delta H f^{\circ}=-356.5 \pm 2.0 \mathrm{kcal} / \mathrm{mol}$. From Markin et al.: $\Delta G$ at $873 \mathrm{~K}=50.27, \Delta \mathrm{H}^{\circ}{ }_{16}=61.63 \pm 1.5$ and $\Delta \mathrm{HF}^{\circ}$ for $\mathrm{UF}_{3}(\mathrm{c})=-356.8 \pm 2.0 \mathrm{kcal} / \mathrm{mol}$.

These two relationships indicate that the measured $\Delta G^{\prime}$ s are good within their experimental uncertainty of $1.0 \mathrm{kcal} / \mathrm{mol}$. Because of the uncertainty in $-\left(\mathrm{G}-\mathrm{H}_{298}\right) / T$ for $\mathrm{UF}_{3}(\mathrm{c})$ and the uncertainties in $\triangle \mathrm{HF}^{\circ}$ of $\mathrm{AlF}_{3}$ (c) and $\mathrm{MgF}_{2}(\mathrm{c})$, the assigned uncertainties on the $\mathrm{UF}_{3}$ values are $\pm 2.0 \mathrm{kcal} / \mathrm{mol}$. 
Markin et al. have also determined the relationship jetween $\mathrm{UF}_{3}(\mathrm{c})$ and $\mathrm{UF}_{4}(\mathrm{c})$.

$$
\begin{gathered}
4 \mathrm{UF}_{3}(\mathrm{c}) \rightarrow 3 \mathrm{UF}_{4}(\mathrm{c})+\mathrm{U}(\mathrm{c}) \\
\Delta G_{873 \mathrm{~K}}=62.20 \text { and } \Delta \mathrm{H}^{\circ}=61.86 \pm 4.0 \mathrm{kcal} / \mathrm{mol}(3 \mathrm{rd} \mathrm{law})
\end{gathered}
$$

This relationship will be used with the results of Heus and Egan, and Markin et al. to calculate the $\Delta \mathrm{Hf}^{\circ}$ 's of $U \mathrm{~F}_{4}(\mathrm{c})$. The calculated $\Delta \mathrm{H}_{11}$ then is $\sim-98 \mathrm{kcal} / \mathrm{mol}$.

B. The Measurements on the Enthalpy of Formation of $U_{4}$ (c)

1. Room Temperature Calorimetry

Khanaev (1968) has made a series of measurements at $323 \mathrm{~K}$ on the $\Delta \mathrm{H}_{\text {soln }}{ }^{\prime s} \cdot \mathrm{UF}_{4}(\mathrm{c}$, monoclinic $)=-3.11 \pm .02 \mathrm{kcal}$ and $\mathrm{UCl}_{4}(\mathrm{c})=-17.91 \pm .05$ kcal in various $\mathrm{HCl}-\mathrm{H}_{3} \mathrm{BO}_{3}$ aqueous solutions, and on the various $\triangle \mathrm{H}_{\operatorname{mix}}$ 's to oitain the relationship between $\mathrm{UCI}_{4}(\mathrm{c})$ and $\mathrm{UF}_{4}(\mathrm{c})$.

The summation of the measured reactions leads to:

$$
\mathrm{UF}_{4}(\mathrm{c})+4 \mathrm{HCl}(\mathrm{aq}) \rightarrow \mathrm{UCl}_{4}(\mathrm{c})+4 \mathrm{HF}(\mathrm{aq}) ; \Delta \mathrm{H}_{1}=49.77 \pm 0.15 \mathrm{kcal} / \mathrm{mol}
$$

where $\Delta \mathrm{H}_{1}$ includes the correction from $\Delta H$ at $323 \mathrm{~K}=51.20 \pm 0.13 \mathrm{kcal} / \mathrm{mol}$ using a $\Delta C_{p}=58 \mathrm{cal} / \mathrm{mol} \cdot \mathrm{K}$.

The concentrations for $\mathrm{HCl}\left(\mathrm{a}_{y}\right)$ and $\mathrm{HF}(\mathrm{aq})$ are the same as for the similar cycles for $\mathrm{UF}_{3}$ (c) by Khanaev and Khripin (1970), so that $\Delta \mathrm{Hf}^{\circ} \mathrm{UF}_{4}(\mathrm{c})=-452.3 \pm 0.9 \mathrm{kcal} / \mathrm{mol}$.

As indicated in the discussion on the $\Delta \mathrm{Hf}^{\circ} \mathrm{UF}_{3}(\mathrm{c})$, the results of Hayman (1967) on the fluorination of $\mathrm{UF}_{4}$ (c) lead to $\triangle \mathrm{Hf}^{\circ} \mathrm{UF}$ values of $-453.7 \pm 0.7$ (if a systematic error is assumed in all their measurements) or $-456.4 \pm 0.5 \mathrm{kcal} / \mathrm{mol}$ (if only $\Delta \mathrm{H}_{13}$ is in error).

The available information on $\mathrm{UF}_{4} \cdot 2.5 \mathrm{H}_{2} \mathrm{O}(\mathrm{c})$ and the various reported hydrates, as well as on the other forms of $\mathrm{UF}_{4}(\mathrm{c})$, must be considered. 
The $\Delta \mathrm{Hf}^{\circ} \mathrm{UF}_{4} \cdot 2 \cdot 5 \mathrm{H}_{2} \mathrm{O}(\mathrm{c})$ may be obtained from the Maltsev et al. (1960) calorimetric measurements involving the precipitation of $\mathrm{UF}_{4} \cdot 2.5 \mathrm{H}_{2} \mathrm{O}(\mathrm{c})$ at $293 \mathrm{~K}$. Their measured reactions (kcal/mol) are: $\mathrm{UCl}_{4}(\mathrm{c})+250 \mathrm{HCl}(\mathrm{aq}) \rightarrow\left[\mathrm{UCl}_{4}+250 \mathrm{HCl}\right] \mathrm{aq} ; \Delta \mathrm{H}_{2}=-43.47 \pm 0.10$ $\left[\mathrm{UCl}_{4}+250 \mathrm{HCl}\right] \mathrm{aq}+18 \mathrm{HF}(\mathrm{aq})+2.5 \mathrm{H}_{2} \mathrm{O}(\mathrm{aq}) \rightarrow \mathrm{UF}_{4} \cdot 2.5 \mathrm{H}_{2} \mathrm{O}(\mathrm{c})+$ $[254 \mathrm{HCl}+14 \mathrm{HF}] \mathrm{aq} ; \Delta \mathrm{H}_{3}=-20.96 \pm 0.32$

$[250 \mathrm{HCl}+18 \mathrm{HF}] \mathrm{aq} \rightarrow 250 \mathrm{HCl}(\mathrm{aq})+18 \mathrm{HF}(\mathrm{aq}) ; \Delta \mathrm{H}_{4}=5.30 \pm 0.12$

The sumation, $\Delta \mathrm{H}_{5}=\Delta \mathrm{H}_{2}+\Delta \mathrm{H}_{3}+\Delta \mathrm{H}_{4}=-59.15 \pm 0.4$ is for:

$$
\begin{aligned}
\mathrm{UCl}_{4}(\mathrm{c})+[250 \mathrm{HCl}+18 \mathrm{HF}] \mathrm{aq}+2.5 \mathrm{H}_{2} \mathrm{O}(\mathrm{aq}) \rightarrow & {[254 \mathrm{HCl}+14 \mathrm{HF}] \mathrm{aq} } \\
& +\mathrm{UF}_{4} \cdot 2.5 \mathrm{H}_{2} \mathrm{O}(\mathrm{c})
\end{aligned}
$$

The authors have calculated

$$
\begin{array}{r}
4 \mathrm{HF}(\mathrm{g})+[254 \mathrm{HCl}+14 \mathrm{HF}] \mathrm{aq} \rightarrow 4 \mathrm{HCl}(\mathrm{g})+[250 \mathrm{HCl}+18 \mathrm{HF}] \mathrm{aq} \\
{\Delta \mathrm{H}_{6}}_{6}=4 \times(5.68 \pm 0.50)
\end{array}
$$

using unevaluated literature data for the $\Delta H_{\text {soln }} H F(g) \rightarrow H F(a q)$ and $\Delta \mathrm{H}_{\text {Soln }} \mathrm{HCl}(\mathrm{g}) \rightarrow \mathrm{HCl}(\mathrm{aq})$ to obtain:

$$
4 \mathrm{HF}(\mathrm{g})+4 \mathrm{HCl}(\mathrm{aq})-4 \mathrm{HCl}(\mathrm{g})+4 \mathrm{HF}(\mathrm{aq}) ; \Delta \mathrm{H}_{7}=5.68 \times 4
$$

This $\Delta H$ was assumed to be equal to their $\Delta H_{6}$.

This approach leads to:

$$
\begin{array}{r}
\mathrm{UCl}_{4}(\mathrm{c})+4 \mathrm{HF}(\mathrm{g})+2.5 \mathrm{H}_{2} \mathrm{O}\left(\mathrm{Il} \rightarrow \mathrm{UF}_{4} \cdot 2.5 \mathrm{H}_{2} \mathrm{O}(\mathrm{c})+4 \mathrm{HCI}(\mathrm{g}) ;\right. \\
\Delta \mathrm{H}_{8}=-36.43 \pm 2.1
\end{array}
$$

which corrected to $298 \mathrm{~K}\left(\Delta_{\mathrm{p}}=-24 \mathrm{cal} / \mathrm{mol} \cdot \mathrm{K}\right)$ is $-36.55 \pm 2.1 \mathrm{kca} 1$ and $\Delta \mathrm{Hf}^{\circ} \mathrm{UF}_{4} \cdot 2.5 \mathrm{H}_{2} \mathrm{O}(\mathrm{c})=-623.9 \pm 3.0 \mathrm{kcal} / \mathrm{mol}$.

The $\Delta H_{\text {hydration, }}$ which will be discussed and evaluated separately, for:

$$
\mathrm{UF}_{4}(\mathrm{c})+2.5 \mathrm{H}_{2} \mathrm{O}(1) \rightarrow \mathrm{UF}_{4} \cdot 2.5 \mathrm{H}_{2} \mathrm{O}(\mathrm{c})
$$


is $\sim-10 \mathrm{kcal} / \mathrm{mol} \mathrm{UF}_{4}(\mathrm{c})$. This results in a $\Delta \mathrm{Hf}^{\circ} \mathrm{UF}_{4}(\mathrm{c})=-443 \mathrm{kcal} / \mathrm{mol}$ which is not reasonable.

A better approach would be to use the experimental summation, (4) which contains a mixture of $\mathrm{HF}$ and $\mathrm{HCl}$ on both sides of the equation differing only by the removal of $4 \mathrm{HF}(\mathrm{aq})$ and the addition of $4 \mathrm{HCl}(\mathrm{aq})$ and assume that the differentials, $\triangle \overline{\mathrm{H}} f$ for the $\mathrm{HCl}, \mathrm{HF}$, and $\mathrm{H}_{2} \mathrm{O}$ at the appropriate concentrations are to be used; the assumption, of course, is that the $\triangle \bar{H} f$ of $\mathrm{HCl}(a q)$ and $\mathrm{HF}\left(a_{y}\right)$ would be the same as in pure solutions.

Schematically, then, and corrected to $298 \mathrm{~K}$ :

$$
\begin{array}{r}
\mathrm{UCl}_{4}(\mathrm{c})+4 \mathrm{HF}(\mathrm{aq})+2.5 \mathrm{H}_{2} \mathrm{O}(\mathrm{aq}) \rightarrow \mathrm{UF}_{4} \cdot 2.5 \mathrm{H}_{2} \mathrm{O}(\mathrm{c})+4 \mathrm{HCl}(\mathrm{aq}) ; \\
\Delta \mathrm{H}_{10}=-59.68 \pm 0.5 \mathrm{kcal} / \mathrm{mol}
\end{array}
$$

With the differential $\triangle \mathrm{Hf}^{\circ}$ 's for $\mathrm{HCl}\left(10.04 \mathrm{H}_{2} \mathrm{O}\right), \mathrm{H}_{2} \mathrm{O}$, and $\mathrm{HF}\left(160 \mathrm{H}_{2} \mathrm{O}\right)$, the resultant $\Delta \mathrm{Hf}^{\circ} \mathrm{UF}_{4} \cdot 2.5 \mathrm{H}_{2} \mathrm{O}(\mathrm{c})=-633.2 \pm 1.0 \mathrm{kca} 1 / \mathrm{mol}$ which means that $\triangle \mathrm{HF}^{\circ} \mathrm{UF}_{4}(\mathrm{c})$ is $\sim-452.4 \mathrm{kcal} / \mathrm{mol}$.

\section{High Temperature Equilibria}

Briggs (1960) has reported the $K^{\prime} s$ in the range 622 to $955 \mathrm{~K}$ for the equilibrium:

$$
\mathrm{UO}_{2}(\mathrm{c})+4 \mathrm{HF}(\mathrm{g}) \rightarrow \mathrm{UF}_{4}(\mathrm{c})+2 \mathrm{H}_{2} \mathrm{O}(\mathrm{g}) .
$$

The $\Delta \mathrm{H}=-50.6 \mathrm{kcal} / \mathrm{mol} \mathrm{UF}_{4}(\mathrm{c})$ at the mean $\mathrm{T}$ results in $\Delta \mathrm{H}^{\circ}=-50.84 \mathrm{kcal} / \mathrm{mol}$ and $\Delta \mathrm{Hf}^{\circ}=-455.88 \mathrm{kcal} / \mathrm{mol}$. The third law value for $\Delta H^{\circ}=-51.90 \pm 0.92$ results in $\Delta \mathrm{Hf}^{\circ}=-456.99 \mathrm{kcal}$. 
The earlier measurements were evaluated by Rand and Kubaschewski

who cite $\Delta G_{11}=-50,000+57.7 \mathrm{~T} \mathrm{cal} \mathrm{mol}-1$ for the range 700 to $900 \mathrm{~K}$. This results in a 3rd law $\Delta \mathrm{H}^{\circ}=-50.12$ and $\Delta \mathrm{Hf}^{\circ} \mathrm{UF}_{4}(\mathrm{c})=-455.1$

kcal/mol. The other measurements cited by Rand and Kubaschewski are:

(1) Johns and Walsh (1945) (temperature range 873-1073 K)

2nd law $\Delta H=-42.83 ; \Delta \mathrm{HF}^{\circ}=-447.82 \mathrm{kcal} / \mathrm{mol}$

3rd law $\Delta H=-56.46 \pm 2.8 ; \Delta H f^{\circ}=-461.45$

(2) Domange and Wohlhuter (1949) (temperature range $374-773 \mathrm{~K}$ )

2nd law $\Delta H=-27.4$

3rd law $\Delta H=-49 \cdot 1 \pm 9 \cdot 0$

These two sets are given no further consideration.

3. Room Temperature Aqueous Equilibria

Vdovenko et al. (1963) reported for the following equilibria:

$$
\begin{aligned}
& U^{+4}(a q)+F^{-}(a q) \rightarrow U F^{3+}(a q) ; \log K=7.15 \\
& U^{+4}(a q)+2 F^{-}(a q) \rightarrow U F_{2}{ }^{2+}(a q) ; \log K=12.4 \\
& U^{+4}(a q)+3 F^{-}(a q) \rightarrow U F_{3}{ }^{+}(a q) ; \log K=17.7 \\
& U^{+4}(a q)+4 F^{-}(a q)-U F_{4}(a q) ; \log K=23.1 \text { (extrap. value) }
\end{aligned}
$$

Savage and Browne (1960) reported:

$$
\begin{aligned}
& U F_{4} \cdot 2.5 \mathrm{H}_{2} \mathrm{O}(\mathrm{c}) \rightarrow \mathrm{UF}_{4}(\mathrm{aq}) ; \mathrm{K}=1.09 \times 10^{-4} \mathrm{molal} \\
& \mathrm{UF}_{4}(\mathrm{aq}) \rightarrow \mathrm{UF}_{3}^{+}(\mathrm{aq})+\mathrm{F}^{-}(\mathrm{aq}) ; \mathrm{K}=5.4 \times 10^{-5} \mathrm{molal} \\
& \mathrm{UF}_{3}^{+}(\mathrm{aq}) \rightarrow \mathrm{UF}_{2}^{+2}(\mathrm{aq})+\mathrm{F}^{-}(\mathrm{aq}) ; \mathrm{K}=5.9 \times 10^{-5} \mathrm{molal}
\end{aligned}
$$

From the combination of (16) and (15) we obtain:

$$
\mathrm{UF}_{4} \cdot 2.5 \mathrm{H}_{2} \mathrm{O}(\mathrm{c}) \rightarrow \mathrm{U}^{+4}(\mathrm{aq})+4 \mathrm{~F}^{-}(\mathrm{a}, \mathrm{q})+2.5 \mathrm{H}_{2} \mathrm{O}(1) ; \quad \Delta \mathrm{G}_{19}^{\circ}=+36.9 \mathrm{kcal} / \mathrm{mol}
$$

which results in $\mathrm{iGf}^{\circ} \mathrm{UF}_{4} \cdot 2.5 \mathrm{H}_{2} \mathrm{O}(\mathrm{c})=-574.9 \mathrm{kcal} / \mathrm{mol}$. 
If it is assumed that $\mathrm{S}^{\circ} \mathrm{UF}_{4} \cdot 2.5 \mathrm{H}_{2} \mathrm{O}(\mathrm{c})=60.0 \pm 2.0 \mathrm{cal} / \mathrm{mol} \cdot \mathrm{K}$, then the calculated $\Delta \mathrm{Hf}^{\circ}$ for $\mathrm{UF}_{4} \cdot 2.5 \mathrm{H}_{2} \mathrm{O}(\mathrm{c})=-631.0 \mathrm{kcal} / \mathrm{mol}$ and $\Delta \mathrm{Hf}^{\circ} \mathrm{UF}_{4}(\mathrm{c}) \approx-450.2 \mathrm{kcal} / \mathrm{mol}$.

Other combinations for the equilibria (19) are possible from various combinations of the Vdovenko et al. data with the Savage and Brown data, such as $\Delta G^{\circ}{ }_{19}=+35.4$ from $(16)+(17)-(14)$ which would result in $-629.5 \mathrm{kcal} / \mathrm{mol}$ for $\Delta \mathrm{Hf}^{\circ} \mathrm{UF}_{4} \cdot 2.5 \mathrm{H}_{2} \mathrm{O}(\mathrm{c})$ and $\Delta \mathrm{Hf}^{\circ} \mathrm{UF}_{4}(\mathrm{c})=$ $-448.7 \mathrm{kcal} / \mathrm{mol}$.

4. High Temperature EMF Measurements

As indicated under $\mathrm{UF}_{3}(\mathrm{c})$, Markin et al. (1967) have determined the relationship between $\mathrm{UF}_{3}(\mathrm{c})$ and $\mathrm{UF}_{4}(\mathrm{c})$, as :

$$
\Delta G_{873 \mathrm{~K}}=62.20 \mathrm{kcal} / \mathrm{mol}
$$

for

$$
4 \mathrm{UF}_{3}(c) \rightarrow 3 \mathrm{UF}_{4}(\mathrm{c})+\mathrm{U}(\mathrm{c})
$$

Their results and Heus and Egan's (1966) EMF measurements on $\mathrm{UF}_{3}(\mathrm{c})$ can then be converted to relationships involving $\mathrm{UF}_{4}(\mathrm{c})$ and $\mathrm{MgF}_{2}(\mathrm{c})$, and $\mathrm{UF}_{4}(\mathrm{c})$ and $\mathrm{AlF}_{3}(\mathrm{c})$ negating the added uncertainty of the estimated themal functions of $\mathrm{UF}_{3}(\mathrm{c})$ on the reactions involving $\mathrm{UF}_{3}(\mathrm{c})$.

Then for:

$$
\mathrm{Al}(\mathrm{c})+3 / 4 \mathrm{UF}_{4}(\mathrm{c})-\mathrm{AlF}_{3}(\mathrm{c})+3 / 4 \mathrm{U}(\mathrm{c})
$$

from Heus and Egan, $\Delta H^{\circ}=-19.2 \mathrm{kcal} / \mathrm{mol}$ and $\Delta \mathrm{Hf}^{\circ}=-455.7 \pm 1.0 \mathrm{kca} 1 / \mathrm{mol}$, and from Markin et al., $\Delta H=-18.6$ and $\Delta H \mathrm{f}^{\circ}=-456.5 \pm 1.0 \mathrm{kcal} / \mathrm{mol}$. 
Similarly for:

$$
\mathrm{U}(\mathrm{c})+2 \mathrm{MgF}_{2}(\mathrm{c}) \rightarrow 2 \mathrm{Mg}(\mathrm{c})+\mathrm{UF}_{4}(\mathrm{c})
$$

from Heus and Egan, $\Delta H^{\circ}=82.7 \mathrm{kcal}$ and $\Delta H f^{\circ}=-454.7 \pm 1.0 \mathrm{kcal} / \mathrm{mol}$; from Markin et al $\Delta H^{\circ}=82.3$ and $\Delta H^{\circ}=-455.1 \pm 1.0 \mathrm{kcal} / \mathrm{mol}$.

C. The Selection of Values for the Enthalpies of Formation of $\mathrm{UF}_{3}(\mathrm{c})$ and $\mathrm{UF}_{4}(\mathrm{c})$

As can be seen from the range of values for $\Delta \mathrm{Hf}^{\circ}$ 's for $\mathrm{UF}_{3}$ (c) and $U F_{4}(c)$, Table 1 , the selected values can not be considered definitive; however a reasonable presentation of the relationships can be made with $\Delta \mathrm{Hf}^{\circ} \mathrm{UF}_{4}(\mathrm{c})=-455.5 \pm 1.0 \mathrm{kcal} / \mathrm{mol}$.

$$
\begin{gathered}
\Delta\left(\Delta \mathrm{HF}^{\circ} \mathrm{UF}_{3}(\mathrm{c})-\Delta \mathrm{Hf}^{\circ} \mathrm{UF}_{4}(\mathrm{c})\right)=98.2 \pm 1.0 \mathrm{kcal} / \mathrm{mol} \\
\Delta \mathrm{HF}^{\circ} \mathrm{UF}_{3}(\mathrm{c})=-357.3 \pm 1.5 \mathrm{kca} 1 / \mathrm{mol}
\end{gathered}
$$

The data derived from the aqueous equilibria measurements are suspect; the hydrate system is a complex one; the K's given are not true equilibrium constants.

The more disturbing values are those from the Khanaev measurements; many reactions are involved in their paths to $\mathrm{UF}_{3}$ (c) and $\mathrm{UF}_{4}$ (c) from $\mathrm{UO}_{2} \mathrm{Cl}_{2}(\mathrm{c})$ and $\mathrm{UCl}_{4}(\mathrm{c})$; it does nct appear reasonable to assume that all the measurements are in error and that these errors are additive, particularly since the relationship between $\mathrm{UCI}_{4}(\mathrm{c})$ and $\mathrm{UO}_{2} \mathrm{Cl}_{2}(\mathrm{c})$ is in excellent agreement with that from the selected values for $\Delta \mathrm{Hf}^{\circ}$ 's $\mathrm{UCl}_{4}(\mathrm{c})$ and $\mathrm{UO}_{2} \mathrm{Cl}_{2}(\mathrm{c})$. One of the reactions in common for both compounds is the $\Delta \mathrm{H}_{\mathrm{mix}}$. of $\mathrm{HF}\left(1.33 \mathrm{H}_{2} \mathrm{O}\right)$ with the appropriate solution; if the $\Delta \mathrm{H} \mathrm{mix}$. should be $0.7 \mathrm{kcal} / \mathrm{mol} \mathrm{HF}$ more negative, the $\Delta\left(\Delta \mathrm{Hf}^{\circ} \mathrm{UF}_{3}-\Delta \mathrm{Hf}^{\circ} \mathrm{UF}_{4}\right)$ would become 98.2 in agreement with the Markin et al (1967) EMF measurements and would result in 
$\triangle H f^{\circ}$ of $U F_{3}(c)$ and $U F_{4}(c) \approx-357$ and $-455 \mathrm{kcal} / \mathrm{mol}$, respectively. The $\mathrm{UF}_{4} \cdot 2.5 \mathrm{H}_{2} \mathrm{O}$ value may have a similar error in $\triangle \mathrm{H}$ mix. Obvious $1 \mathrm{y}$ all of this is conjecture.

D. The Enthalpy of Hydration of $\mathrm{UF}_{4}$ (c, monoclinic) to $\mathrm{UF}_{4} \cdot 2 \cdot 5 \mathrm{H}_{2} \mathrm{O}(\mathrm{c}$, or thorhombic)

As indicatad in C, from the Maltsa et a1. (1960) reactions involving the precipitation of $\mathrm{UF}_{4} \cdot 2.5 \mathrm{H}_{2} \mathrm{O}(\mathrm{c})$ from $\mathrm{UCl}_{4}-\mathrm{HCl}$ solutions, $\Delta \mathrm{HF}^{\circ} \mathrm{UF}_{4} \cdot 2.5 \mathrm{H}_{2} \mathrm{O}(\mathrm{c})=-633.2 \pm 1.0 \mathrm{kcal} / \mathrm{mol}$.

Gagarinskii and Khanaev (1967) have measured the $\Delta H$ 's of solution of $\mathrm{UF}_{4}$ (c, monoclinic) and $\mathrm{UF}_{4} \cdot 2 \cdot 5 \mathrm{H}_{2} \mathrm{O}(\mathrm{c})$ at $323 \mathrm{~K}$ and $298 \mathrm{~K}$ to the same final solution.

Their measurements are:

$$
\begin{aligned}
& \mathrm{UF}_{4}(\mathrm{c})+\left[166.5 \mathrm{HCl}+3 \mathrm{H}_{3} \mathrm{BO}_{3}\right] \rightarrow\left[\mathrm{UCl}_{4}+3 \mathrm{H}_{2} \mathrm{O}+\mathrm{HBF}_{4}+\right. \\
& 162.5 \mathrm{HCl}+2 \mathrm{H}_{3} \mathrm{BO}_{3} \text { ]aq; } \Delta \mathrm{H}_{23} \\
& {\left[\mathrm{UCl}_{4}+3 \mathrm{H}_{2} \mathrm{O}+\mathrm{HBF}_{4}+162.5 \mathrm{HCl}+2 \mathrm{H}_{3} \mathrm{BO}_{3}\right] \mathrm{aq}+2.5 \mathrm{H}_{2} \mathrm{O} \text { (1iq) }} \\
& \rightarrow\left[\mathrm{UCl}_{4}+5.5 \mathrm{H}_{2} \mathrm{O}+\mathrm{HBF}_{4}+162.5 \mathrm{HCl}+2 \mathrm{H}_{3} \mathrm{BO}_{3}\right] \mathrm{aq} ; \Delta \mathrm{H}_{24} \\
& \mathrm{UF}_{4} \cdot 2.5 \mathrm{H}_{2} \mathrm{O}(\mathrm{c})+\left[166.5 \mathrm{HCl}+3 \mathrm{H}_{3} \mathrm{BO}_{3}\right] \mathrm{aq} \rightarrow\left[\mathrm{UCl}_{4}+5.5 \mathrm{H}_{2} \mathrm{O}\right. \\
& \left.+\mathrm{HBF}_{4}+162.5 \mathrm{HCl}+2 \mathrm{H}_{3} \mathrm{BO}_{3}\right] ; \mathrm{\Delta H}_{25}
\end{aligned}
$$

then for:

$$
\begin{gathered}
\mathrm{UF}_{4}(\mathrm{c})+2.5 \mathrm{H}_{2} \mathrm{O}(\mathrm{Iiq}) \rightarrow \mathrm{UF}_{4} \cdot 2.5 \mathrm{H}_{2} \mathrm{O}(\mathrm{c}) ; \Delta \mathrm{H}_{26} \\
\Delta \mathrm{H}_{26}=\Delta \mathrm{H}_{23}+\Delta \mathrm{H}_{24}-\Delta \mathrm{H}_{25}
\end{gathered}
$$

At $323 \mathrm{~K}: \Delta \mathrm{H}_{23}=-2.74 \pm 0.02 \mathrm{kcal}$

$$
\begin{aligned}
& \Delta \mathrm{H}_{24}=-2.629 \pm 0.001 . \\
& \Delta \mathrm{H}_{25}=+5.13 \pm 0.01
\end{aligned}
$$

$$
\Delta \mathrm{H}_{26}=-10.50 \pm .025 \mathrm{kcal}
$$


At $298 \mathrm{~K}: \Delta \mathrm{H}_{23}=-4.73 \pm 0.05 \mathrm{kcal}$

$$
\begin{aligned}
& \Delta \mathrm{H}_{24}=-2.405 \pm 0.003 \\
& \Delta \mathrm{H}_{25}=+3.21 \pm 0.03 \\
& \Delta \mathrm{H}_{26}=-10.34 \pm .06
\end{aligned}
$$

Correcting $\triangle \mathrm{H}_{26}$ from $323 \mathrm{~K}$ to $293 \mathrm{~K}\left(\Delta_{\mathrm{D}}=-22 \mathrm{cai} / \mathrm{mol} \cdot \mathrm{K}\right)$ results in $\Delta \mathrm{H}_{26}=-9.94 \mathrm{kcal} / \mathrm{mol}$. A weighted average for $\Delta \mathrm{H}_{26}$ at $298 \mathrm{k}$, then, is $-10.2 \pm 0.2 \mathrm{kcal} / \mathrm{mol}$.

From an inspection of the values calculated from $\Delta H f^{\circ} \mathrm{UF}_{4}(\mathrm{c})$ and $\triangle \mathrm{Hf}^{\circ} \mathrm{UF}_{4} \cdot 2.5 \mathrm{H}_{2} \mathrm{O}(\mathrm{c})$ from the Khanaev measurements and the Maltsev et al. measurements, one can calculate:

$$
\Delta \mathrm{H}_{26}=-633.2+2.5 \times 68.315+452.3=-10.11 \mathrm{kcal}
$$

which indicates a consistent cycle.

Popov et al. (1957) reported the $\Delta \mathrm{H}_{\text {hydration }}$ of $\mathrm{UF}_{4}(\mathrm{c})$ at $293 \mathrm{~K}$ to be $-8.21 \neq 0.02 \mathrm{kcal} / \mathrm{mol} \mathrm{UF}_{4}$. The samples of $\mathrm{UF}_{4}$ were obtained by dehydrating the crystalline $\mathrm{UF}_{4} \cdot 2 \cdot 5 \mathrm{H}_{2} \mathrm{O}(\mathrm{c})$ in.vacuo, gradually heating to $498 \mathrm{~K}$.

In addition to this Popov and Gagarinskii (1957) reported from tensimetric data

$$
\begin{gathered}
\mathrm{UF}_{4} \cdot 2.5 \mathrm{H}_{2} \mathrm{O}(\mathrm{c}) \rightarrow \mathrm{UF}_{4}(\mathrm{c})+2.5 \mathrm{H}_{2} \mathrm{O}(\mathrm{g})(293-318 \mathrm{~K}) ; \\
\log \mathrm{P}_{\mathrm{atm}}=7.154-2,920 / \mathrm{T}
\end{gathered}
$$

so that for the process given:

$$
\begin{aligned}
& \Delta \mathrm{H}=13.36 \times 2.5=33.4 \mathrm{kcal} \\
& \Delta G=3.60 \times 2.5=9.0 \mathrm{kcal} \\
& \Delta S=32.7 \times 2.5=81.75 \mathrm{cal}
\end{aligned}
$$

This would result in $\Delta \mathrm{H}_{26}=-33.4+2.5 \times 10.52^{*}=-7.1 \mathrm{kcal} / \mathrm{mol}$ of $\mathrm{UF}_{4} \cdot 2 \cdot 5 \mathrm{H}_{2} \mathrm{O}(\mathrm{c})$.

${ }^{*} \mathrm{H}_{\text {vap }} \mathrm{H}_{2} \mathrm{O}(1 \mathrm{l}=10.52 \mathrm{kcal} / \mathrm{mol}$ at $298 \mathrm{~K}$. 
This is clearly in error. In addition $\Delta S=32.7 \mathrm{cal} / \mathrm{mol} \mathrm{H}_{2} \mathrm{O} \cdot \mathrm{K}$ is low; one would expect $\Delta S=35-36 \mathrm{cal} / \mathrm{mol} \mathrm{H}_{2} \mathrm{O} \cdot \mathrm{K}$. There is a possibility of a lower hydrate forming.

If it is assumed that the $\Delta G^{\circ}$ is reasonable but that the slope is in error, then $\Delta_{26}=-(9.0+35 \times 2.5 \times .29815)+2.5 \times 10.52=$ $-8.7 \mathrm{kcal} / \mathrm{mol} \mathrm{UF}_{4} \cdot 2.5 \mathrm{H}_{2} \mathrm{O}(\mathrm{c})$, in somewhat better agreement with the Popov et al (1957) $\Delta \mathrm{H}_{26^{\circ}}$

We have selected $\Delta H$ hydration from the results of Gagarinskii and Khanaev (1967), $=-10.2 \pm 0.2 \mathrm{kcal} / \mathrm{mcl}$, since these direct solution measurements are on well characterized samples. This results in $\Delta H^{\circ}$ $\mathrm{UF}_{4} \cdot 2.5 \mathrm{H}_{2} \mathrm{O}(\mathrm{c})=-636.5 \pm 0.2 \mathrm{kcal} / \mathrm{mol}$ (relative to $\Delta \mathrm{Hf}^{\circ} \mathrm{UF}_{4}(\mathrm{c})$ ).

The previously mentioned $\Delta H^{\circ}=-633.2 \mathrm{kcal} / \mathrm{mol}$ from Maltsev et al. (1960 may suffer from incomplete precipitation to $\mathrm{UF}_{4} \cdot 2.5 \mathrm{H}_{2} \mathrm{O}(\mathrm{c})$; more probable is an error in the $\Delta \mathrm{H}_{\text {mix }}$ involving $H F(a q)$; this would cancel in the derived $\Delta H_{\text {hydration }}$ (obtained using the $\Delta \mathrm{Hf} \mathrm{UF}_{4}$ (c) from Khanaev (1968)).

The estimated $\mathrm{S}^{\circ} \mathrm{UF}_{4} \cdot 2.5 \mathrm{H}_{2} \mathrm{O}(\mathrm{c})=60 \pm 2.0 \mathrm{cal} / \mathrm{mol} \cdot \mathrm{K}$ is obtained from the measured $\mathrm{S}^{\circ} \mathrm{UF}_{4}(\mathrm{c})$ plus an estimate for the contribution of the $2.5 \mathrm{H}_{2} \mathrm{O}^{\prime} \mathrm{s}(2.5 \times 9.5)$.

The calculated and accepted $\Delta G f^{\circ}=-580.4 \mathrm{kcal} / \mathrm{mol}$ is obtained from the selected $\Delta H f^{\circ}$ and the $\Delta S f^{\circ}=-188.2 \pm 2.0 \mathrm{cal} / \mathrm{mol} \cdot \mathrm{K}$.

The $\Delta G f^{\circ}$ obtained from the aqueous $K^{\prime} s$ (see Section $C$ ) are in poor agreement. 
E. Lower Hydrates of $\mathrm{UF}_{4}$ and the Various Metastable Forms of $\mathrm{UF}_{4}$ Gagarinskii and Khanaev (1967) have also prepared and measured the $\Delta H$ soln. of various lower hydrates and metastaile forms. These lower hydrates and their dehydration products are ill-defined. The values derived for the $\Delta H_{\text {hydration }} \mathrm{UF}_{4}(c$, monoclinic) to the lower hydrates are inconsistent, i.e.,

$$
\mathrm{UF}_{4}(\mathrm{c})+1.5 \mathrm{H}_{2} \mathrm{O}\left(1 \mathrm{i} \rightarrow \mathrm{UF}_{4} \cdot 1.5 \mathrm{H}_{2} \mathrm{O}(\mathrm{c}) ; \Delta \mathrm{H}=-5.1 \mathrm{kcal} / \mathrm{mol}\right.
$$

but

$$
\mathrm{UF}_{4}(\mathrm{c})+1.33 \mathrm{H}_{2} \mathrm{O}\left(1 \mathrm{j} \rightarrow \mathrm{UF}_{4} \cdot 1.33 \mathrm{H}_{2} \mathrm{O}(\mathrm{c}) ; \Delta \mathrm{H}=-7.44 \mathrm{kcal} / \mathrm{mol}\right.
$$

The metastable forms of $\mathrm{UF}_{4}$ (c) are formed from the lower hydrates and are irreversibly converted to the monoclinic. Again, they are not weIl defined.

An earlier paper by Gagarinskii and Mashirev (1959) also reports on the lower hydrates. 


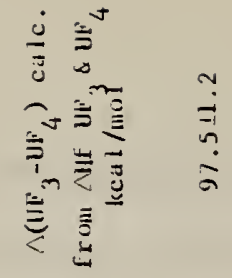

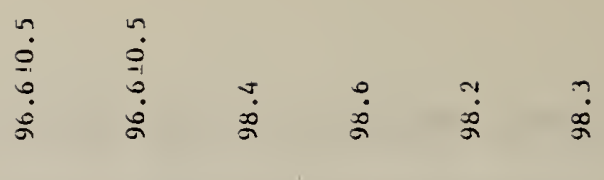

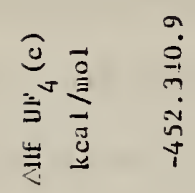

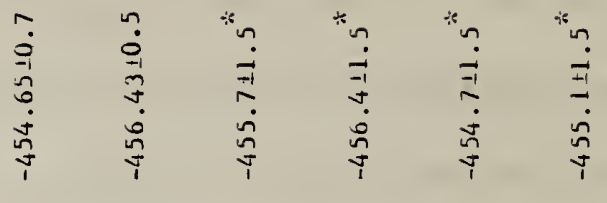

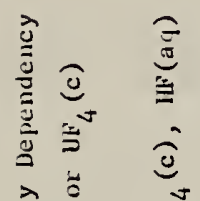

$$
\begin{aligned}
& \text { जे } \\
& \stackrel{n}{\sim}
\end{aligned}
$$

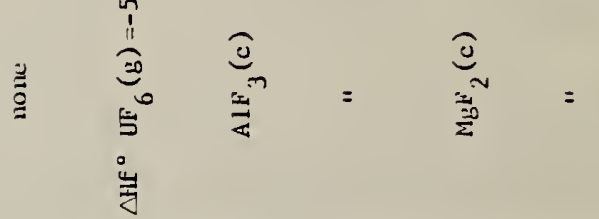

$$
\begin{aligned}
& \text { כ) }
\end{aligned}
$$

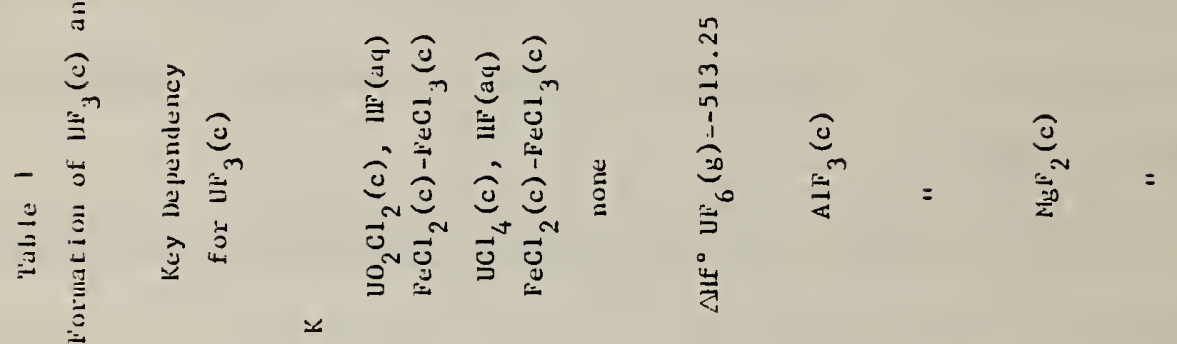

$$
\begin{aligned}
& \text { 글 } \\
& \text { 㟧 }
\end{aligned}
$$

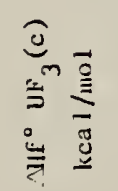

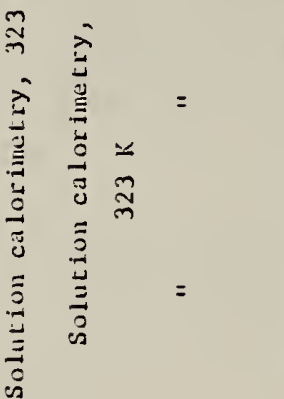

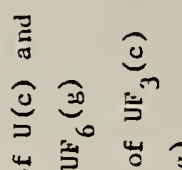

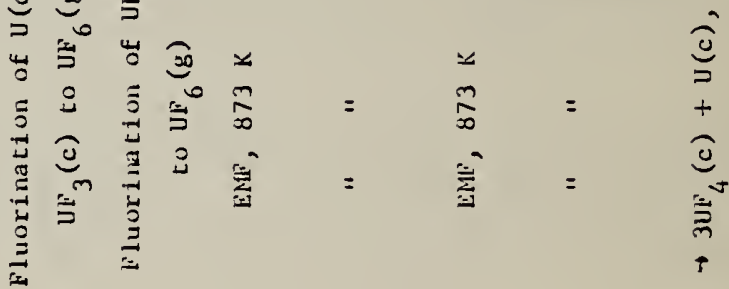

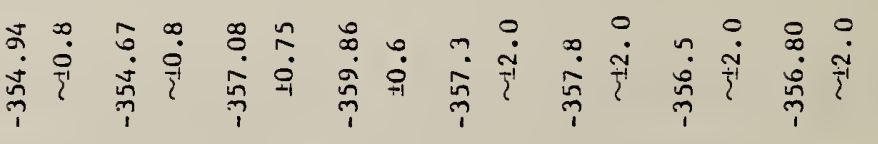

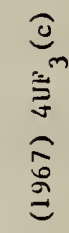

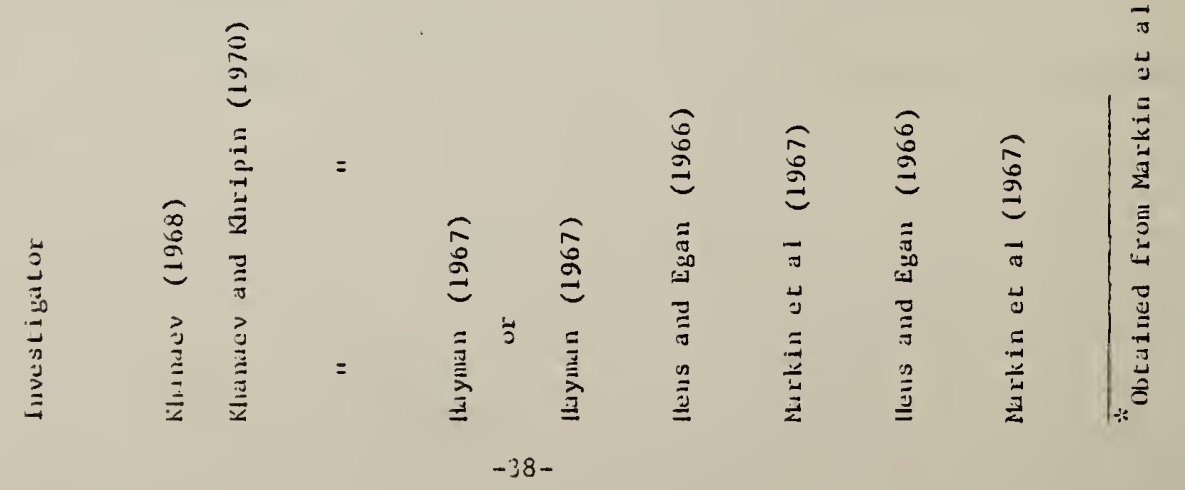


$\mathrm{UF}_{4}(\mathrm{~g})$

Hildenbrand (1976) has calculated the thermal functions for $\mathrm{UF}_{4}(\mathrm{~g})$ using the estimates of Tumanov (1968) where a tetrahedral structure was assumed and the vibrational frequencies were estimated on that basis. These are the assumed parameters:

$$
\begin{aligned}
& \nu_{1}=555 \mathrm{~cm}^{-1} \\
& \nu_{2}=147 \mathrm{"} \\
& \nu_{3}=566 " \\
& \nu_{4}=177 "
\end{aligned}
$$

$\mathrm{T}_{\mathrm{d}}$ model, tetrahedron

$$
\sigma=12
$$

Singlet ground state

$r U-F=2.08 \AA$

However, an analysis of the vapor pressure of $\mathrm{UF}_{4}(\mathrm{c})$ and (1) indicates a serious discrepancy in calculated $\Delta H^{\prime} s$ of sublimation from 2 nd and 3rd. law analyses (which also shows a trend with temperature). The trend can be removed and agreement with the 2 nd law values can be made by increasing $\mathrm{S}^{\circ}$ and $-\left(G-\mathrm{H}_{298}\right) / \mathrm{T}$ by $8.2 \mathrm{cal} / \mathrm{mol} \cdot \mathrm{K}$ (see Table 2 $\Delta \mathrm{H}^{\circ}$ subl $\mathrm{UF}_{4}(\mathrm{c})$ to $\left.(\mathrm{g})\right)$. One can account for about $3.7 \mathrm{cal} / \mathrm{mol} \cdot \mathrm{K}$ of this difference if $\mathrm{UF}_{4}(\mathrm{~g})$ has the less symetrical $\mathrm{C}_{2 \mathrm{v}}$ structure; it had been assumed that the rest was due to a large electronic partition function. However, Gurvich et al. (1977) have indicated that this would not resolve the remaining $4 \mathrm{cal} / \mathrm{mol} \cdot \mathrm{K}$ discrepancy. For convenience the thermal functions are tabulated but with $\mathrm{S}^{\circ}$ and $-\left(\mathrm{G}-\mathrm{H}_{298}\right) / \mathrm{T}$ increased by $8.2 \mathrm{cal} / \mathrm{mol} \cdot \mathrm{K}$. 
Table 2 shows the available vapor pressure measurements on $\mathrm{UF}_{4}(\mathrm{c})$ and (1), the $\Delta \mathrm{H}$ and $\Delta \mathrm{S}$ at the mean temperature, the $2 \mathrm{nd}$ law $\Delta H_{298}$ calculated from the $\Delta\left(\mathrm{H}-\mathrm{H}_{298}\right)$ w for the gas and the condensed phases, and the increment in $S^{\circ}$ needed to resolve the discrepancy between the 2nd law $\Delta H_{298}$ and 3rd law $\Delta H_{298}$ (calculated using $\mathrm{S}^{\circ}$ at $298 \mathrm{~K}=80.18 \mathrm{cal} / \mathrm{mol} \cdot \mathrm{K}$ from the unadjusted thermal functions for $\left.\mathrm{UF}_{4}(\mathrm{~g})\right)$. From these measurements the selections at $298 \mathrm{~K}$ are :

$$
\begin{aligned}
\Delta \mathrm{H}_{\text {Subl }}^{\circ} & =75.4 \pm 0.5 \mathrm{kcal} / \mathrm{mol} \\
\Delta S_{\text {Subl }}^{\circ} & =80.2-36.25+8.2=52.1 \pm 1.5 \mathrm{cal} / \mathrm{mol} \cdot \mathrm{K}
\end{aligned}
$$

leading to $\Delta \mathrm{HF}^{\circ} \mathrm{UF}_{4}(\mathrm{~g})=-380.1 \pm 1.2 \mathrm{kcal} / \mathrm{mol}$. The $\Delta G f^{\circ}=-373.9 \pm 2.0$ $\mathrm{kcal} / \mathrm{mol}$ is calculated from the $\Delta \mathrm{HF}^{\circ}$ and the tabulated $\mathrm{S}^{\circ}=88.4$ $\mathrm{cal} / \mathrm{mol} \cdot \mathrm{K}$ 


$$
\begin{aligned}
& \text { *) }
\end{aligned}
$$

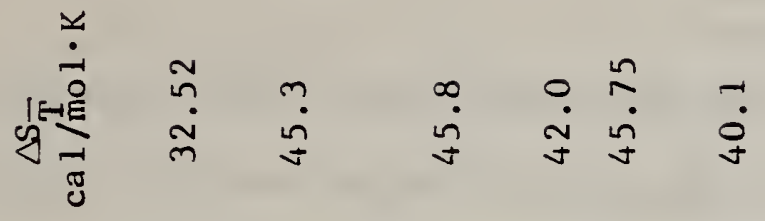

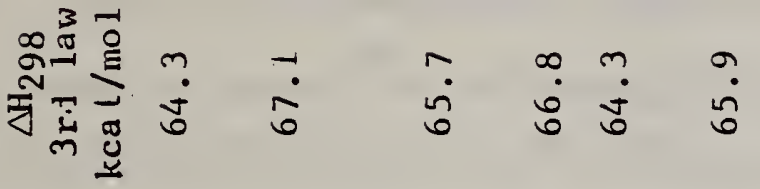

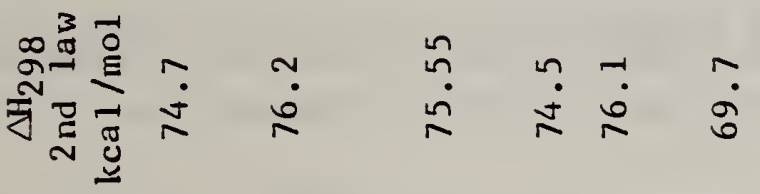

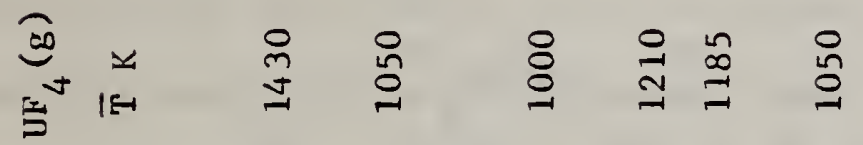

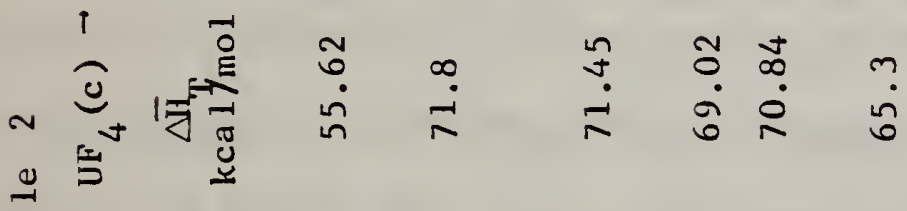

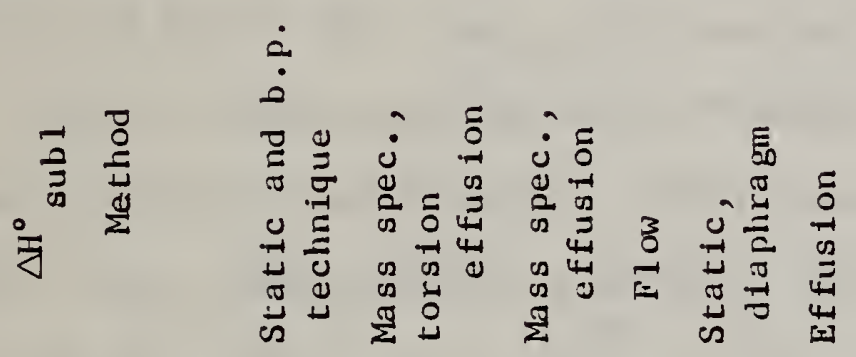

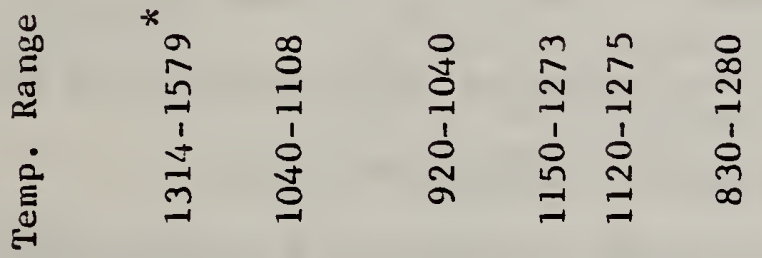

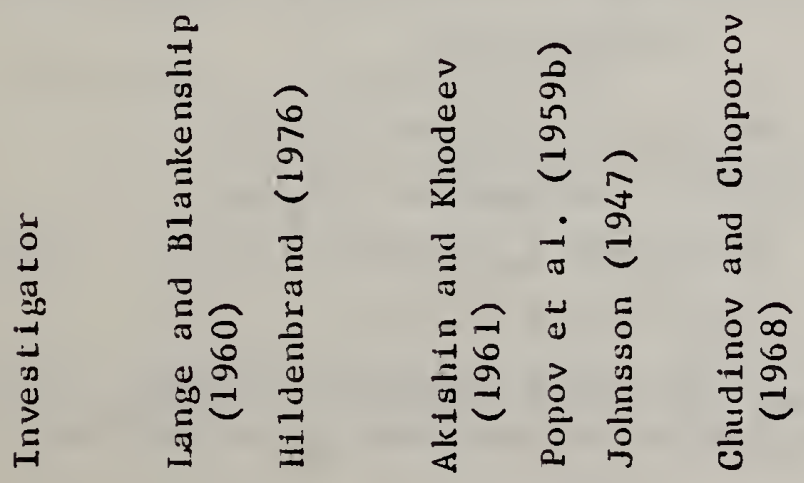

$$
\begin{aligned}
& \text { 芒 } \\
& \text { 吕 }
\end{aligned}
$$

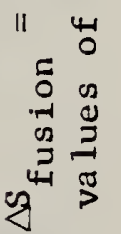

$$
\begin{aligned}
& \ddot{x} \text { is } \\
& \text { \& } \\
& \rightarrow \text { 우 } \\
& \text { गे } \frac{0}{0} \\
& \text { ت. } \\
& \text { * }
\end{aligned}
$$


$\mathrm{UF}_{\mathrm{n}}(\mathrm{c})(\mathrm{n}=4.25,4.5,5)$

Katz and Rabinowitch (1951) and Agron (1958) reported on the properties of $\mathrm{UF}_{4.25}(\mathrm{c}), \mathrm{UF}_{4.5}(\mathrm{c}), \mathrm{UF}_{5}(\mathrm{c}, \alpha)$ and $\mathrm{UF}_{5}(c, \beta)$. Although the $\alpha$-form of $\mathrm{UF}_{5}$ is the stable form above $398 \mathrm{~K}$ (under $1.76 \mathrm{~mm} \mathrm{UF}_{6}(\mathrm{~g})$ ), the $\sim$-form has not been converted to the $\beta$-form at lower temperature. To affect complete conversion of the $\beta$-form to the $\alpha$-form requires 12 hrs heating at $458 \mathrm{k}$. Both $\alpha$ and 3 forms have tetragonal crystal symme try.

Brickwedde (1951) measured the $C_{p}$ of $\mathrm{UF}_{5}(c, \alpha)$ which contained only 83 weight $\% \mathrm{UF}_{5}$. The reported $\mathrm{S}^{\circ} \mathrm{UF}_{5}$ at $298 \mathrm{~K}$ was $45 \pm 3 \mathrm{cal} / \mathrm{mol} \cdot \mathrm{K}$. This value lies between the values for $\mathrm{UF}_{5}(c, \alpha)$ and $\mathrm{UF}_{5}(c, P)$ which are derived from the disproportionation reactions of Agron (1958) on $\mathrm{UF}_{5}(\alpha), \mathrm{UF}_{5}(\beta), \mathrm{UF}_{4.5}(\mathrm{c})$ and $\mathrm{UF}_{4.25}(\mathrm{c})$. The values for $\mathrm{S}^{\circ} \mathrm{UF}_{4.5}$ and $S^{\circ} \mathrm{UF}_{4.25}$ were estimated by Rand and Kubaschewski (1963).

Rand and Kubaschewski (1963) evaluated the disproportionation reactions of Agron (1958) modifying the experimental data (382-621 K) by using their estimated $S^{\circ}$ 's for $\mathrm{UF}_{4.5}(\mathrm{c})$ and $\mathrm{UF}_{4.25}(\mathrm{c})$ and a $\Delta c_{p}=-11 \mathrm{cal} / \mathrm{mol} \cdot \mathrm{K}^{*}$. The following relationships are accepted:

$$
\begin{gathered}
8 \mathrm{UF}_{4.25}(\mathrm{c}) \rightarrow 7 \mathrm{UF}_{4}(\mathrm{c})+\mathrm{UF}_{6}(\mathrm{~g}) \\
\Delta G^{\circ}=33,400-116.5 \mathrm{~T}+25.3 \mathrm{~T} \log \mathrm{T} \mathrm{cal} / \mathrm{mol} \mathrm{UF}_{6}(\mathrm{~g}) \\
(502-621 \mathrm{k})
\end{gathered}
$$

at $298 \mathrm{~K}$

$$
\begin{aligned}
& \Delta \mathrm{H}^{\circ}=30.1 \mathrm{kcal} / \mathrm{mol} \mathrm{UF}{ }_{6}(\mathrm{~g}) \\
& \Delta G^{\circ}=17.4 \mathrm{kcal} / \mathrm{mol} \mathrm{UF}{ }_{6}(\mathrm{~g}) \\
& \Delta \mathrm{S}^{\circ}=42.7 \mathrm{cal} / \mathrm{mol} \cdot \mathrm{K} \mathrm{UF}_{6}(\mathrm{~g})
\end{aligned}
$$

* A slightly better $\Delta \mathcal{C}$ for the disproportionations, $-5 \mathrm{cal} / \mathrm{mol} \cdot \mathrm{K}$, would result in negligible differences in the $\Delta H f^{\circ}$ 's. 


$$
\begin{aligned}
& 7 \mathrm{UF}_{4.5}(\mathrm{c})-6 \mathrm{UF}_{4.25}(\mathrm{c})+\mathrm{UF}_{6}(\mathrm{~g}) \\
& \Delta G^{\circ}=31,100-114.4 \mathrm{~T}+25.3 \mathrm{~T} \log \mathrm{T} \mathrm{cal} / \mathrm{mol} \mathrm{UF}_{4}(\mathrm{~g}) \\
& (533-590 \mathrm{~K})
\end{aligned}
$$

at $298 \mathrm{~K}$

$$
\begin{aligned}
\Delta \mathrm{H}^{\circ} & =27.8 \mathrm{kcal} / \mathrm{mol} \mathrm{UF}{ }_{6}(\mathrm{~g}) \\
\Delta \mathrm{G}^{\circ} & =15.7 \mathrm{kcal} / \mathrm{mol} \mathrm{UF}{ }_{6}(\mathrm{~g}) \\
\Delta \mathrm{S}^{\circ} & =40.7 \mathrm{cal} / \mathrm{mol} \cdot \mathrm{K} \mathrm{UF}{ }_{6}(\mathrm{~g})
\end{aligned}
$$

For the disproportionations of $\alpha-\mathrm{UF}_{5}(c)$ and $\beta-U F_{5}(c)$, however, Rand and Kubaschewskii did not distinguish between the two forms, so that the original measurements of Agron then were refit (with a $\Delta_{p}=-11$ cal/mol $\cdot \mathrm{K}$ ) to obtain:

$$
\begin{gathered}
3 \mathrm{UF}_{5}(\mathrm{c}, \alpha)-2 \mathrm{UF}_{4.5}(\mathrm{c})+\mathrm{UF}_{6}(\mathrm{~g}) \\
\Delta G^{\circ}=18,300-99.8 \mathrm{~T}+25.3 \mathrm{~T} \log \mathrm{T} \mathrm{cal} / \mathrm{mol} \\
(382-469 \mathrm{~K})
\end{gathered}
$$

at $298 \mathrm{~K}$

$$
\begin{aligned}
\Delta \mathrm{H}^{\circ} & =15.0 \mathrm{kcal} / \mathrm{mol} \mathrm{UF}_{6}(\mathrm{~g}) \\
\Delta \mathrm{G}^{\circ} & =7.3 \mathrm{kcal} / \mathrm{mol} \mathrm{UF}_{6}(\mathrm{~g}) \\
\Delta \mathrm{S}^{\circ} & =26.1 \mathrm{cal} / \mathrm{mol} \cdot \mathrm{K} \mathrm{UF}_{6}(\mathrm{~g}) \\
3 \mathrm{UF}_{5}(\mathrm{c}, 3)-2 \mathrm{UF}_{4.5}(\mathrm{c})+\mathrm{UF}_{6}(\mathrm{~g}) & \\
\Delta G^{\circ}=24,000- & 114.0 \mathrm{~T}+25.3 \mathrm{~T} \mathrm{log} \mathrm{T} \mathrm{cal} / \mathrm{mol} \\
& (384-423 \mathrm{~K})
\end{aligned}
$$

at $298 \mathrm{~K}$

$$
\begin{aligned}
& \Delta \mathrm{H}^{\circ}=20.7 \mathrm{kcal} / \mathrm{mol} \mathrm{UF}{ }_{6}(\mathrm{~g}) \\
& \Delta G^{\circ}=8.7 \mathrm{kca} 1 / \mathrm{mol} \mathrm{UF}{ }_{6}(\mathrm{~g}) \\
& \Delta S^{\circ}=40.4 \mathrm{ca} 1 / \mathrm{mol} \cdot \mathrm{K} \mathrm{UF} \\
& 6
\end{aligned}
$$

These equations result in the tabulated values (Section III). Then, from (3) and (4) for:

$$
\mathrm{UF}_{5}(c, \beta)-\mathrm{UF}_{5}(c, \alpha)
$$

at $298 \mathrm{~K}$

$$
\begin{aligned}
\Delta H & =1.9 \mathrm{kcal} / \mathrm{mol} \\
\Delta G & =0.5 \mathrm{kcal} / \mathrm{mol} \\
\Delta S & =4.8 \mathrm{cal} / \mathrm{mol} \cdot \mathrm{K}
\end{aligned}
$$




\section{$\underline{\mathrm{UF}_{5}(\mathrm{~g})}$}

Krohn et a1. (1976) estimated the vibrational assigrment for $\mathrm{UF}_{5}(g)$ on the basis of the $\mathrm{C}_{4 \mathrm{v}}$ pyramidal structure $(\sigma=4)$. Hildenbrand (1976) used these with the $U-F$ bond length $=1.995 \AA$ and a doublet electronic ground state $==$ calculate the thermal functions for $\mathrm{UF}_{5}(g)$. These functions are accepted as modified below.

Hildenbrand (1976) using high temperature mass spectrometry studied the gaseous equilibrium (range 1012-1158 K):

$$
\mathrm{Ag}(\mathrm{g})+\mathrm{UF}_{5}(\mathrm{~g}) \rightarrow \mathrm{AgF}(\mathrm{g})+\mathrm{UF}_{4}(\mathrm{~g})
$$

The experimental $\Delta S^{\circ}{ }_{1100 \mathrm{~K}}=8.9 \pm 1.0 \mathrm{cal} / \mathrm{mol} \cdot \mathrm{K}$ results in $\mathrm{S}^{\circ} \mathrm{UF}_{5}(\mathrm{~g}) \approx$ $131.1 \mathrm{cal} / \mathrm{mol} \cdot \mathrm{K}$, at $1100 \mathrm{~K}, \sim 3 \mathrm{cal} / \mathrm{mol} \cdot \mathrm{K}$ higher than the calculated $\mathrm{S}^{\circ}=128$ cal/mol $\cdot K$. The tabulated $S$ and $-\left(G-H_{298}\right) / T$ have been increased by these $3 \mathrm{cal} / \mathrm{mol} \cdot \mathrm{K}$. These are to be considered approximate functions.

The 2nd law $\Delta H=15.6 \pm 0.6 \mathrm{kcal} / \mathrm{mol}$ corrects to $\Delta H^{\circ}{ }_{1}=16.9 \pm 1.5$ kca 1/mol. Using:

$$
\mathrm{AgF}(\mathrm{g}) \rightarrow \mathrm{Ag}(\mathrm{g})+\mathrm{F}(\mathrm{g}) ; \Delta \mathrm{H}^{\circ}{ }_{2}=84.8 \pm 4.0 \mathrm{kcal} / \mathrm{mol}
$$

from Clements and Barrow (1968), and Hildenbrand's determination:

$$
\mathrm{UF}_{4}(\mathrm{c}) \rightarrow \mathrm{UF}_{4}(\mathrm{~g}) ; \Delta \mathrm{H}_{3}^{\circ}=76.2 \mathrm{kca} 1 / \mathrm{mol}
$$

the following is obtained:

$$
U F_{5}(g) \rightarrow U F_{4}(c)+F(g) ; \Delta H_{4}^{\circ}=25.5 \pm 4.5 \mathrm{kcal} / \mathrm{mol}
$$

The resultant $\triangle H f^{\circ} \mathrm{UF}_{5}(g)=-462 . \pm 5.0 \mathrm{kcal} / \mathrm{mol}$.

From electron impact threshold measurements Hildenbrand also reports :

$$
U F_{6}(g) \rightarrow U F_{5}(g)+F(g)
$$




$$
D_{0}^{0}=2.955 \mathrm{e} \cdot \mathrm{v} \text {. or } 68.0 \pm 0.2 \mathrm{kcal} / \mathrm{mol}
$$

so that $\Delta H^{\circ}{ }_{298} \approx 69 \mathrm{kcal} / \mathrm{mol}$ and $\Delta H f^{\circ} U_{5}(g)=-463.3 \pm 3.3 \mathrm{kcal} / \mathrm{mol}$.

Wolf et al. (1965) determined the vapor pressure of the $\alpha$ form of $\mathrm{UF}_{5}$ (c) from $555 \mathrm{~K}$ to the experimentally determined melting point, $621^{\circ} \mathrm{K}$ as well as that of the liquid to $685^{\circ} \mathrm{K}$ by measurements of the transpiration rates, using $\mathrm{UF}_{6}$ as the carrier gas to prevent disproportionation of the $\mathrm{UF}_{5}$. The following vapor pressure equations were derived:

$$
\begin{aligned}
& U F_{5}(c, \alpha): \\
& \log P(a t m)=-(8001 \pm 664) / T+(11.113 \pm 1.119),(555-621 \mathrm{~K}) \\
& U F_{5}(1 \text { iq }): \\
& \quad \log P(\text { atm })=-(5388 \pm 803) / T+(6.938 \pm 1.236),(621-685 \mathrm{~K})
\end{aligned}
$$

The calculated mean $\Delta \mathrm{H}_{\text {sub } 1}$ and $\Delta S_{\text {subl }}^{\circ}$ at $580 \mathrm{~K}=36.6 \pm 3.0$ $\mathrm{kca} 1 / \mathrm{mol}$ and $50.8 \pm 4.5 \mathrm{cal} / \mathrm{mol} \cdot \mathrm{K}$. Correcting to 298 using an estimated $\Delta C_{p}=-7 \mathrm{cal} / \mathrm{mol} \cdot \mathrm{K}$ results in $\Delta H^{\circ}=38.6 \pm 3.2$ and $\Delta S^{\circ}=55.6 \pm 5.0$, leading to $\Delta \mathrm{Hf}^{\circ} \mathrm{UF}_{5}(\mathrm{~g})=-456 \pm 3.6 \mathrm{kcal} / \mathrm{mol}$ and $\mathrm{S}^{\circ}=104 \pm 5.4 \mathrm{cal} / \mathrm{mol} \cdot \mathrm{K}$. The entropy appears particularly high. One would not expect $S^{\circ} U_{5}(g)$, even including an electronic contribution, to be greater than 94 $\mathrm{ca} 1 / \mathrm{mol} \cdot \mathrm{K}$. In addition, the calculated $\Delta \mathrm{S}_{\text {fusion }}=19 \mathrm{cal} / \mathrm{mol} \cdot \mathrm{K}$ appears high; one would expect $\Delta_{\text {fusion }}=12-14 \mathrm{cal} / \mathrm{mol} \cdot \mathrm{K}$.

A third law analysis of the vapor pressure measurements on the crysta 1, however, results in $\Delta \mathrm{H}_{\text {subl }}^{\circ}=32.6 \mathrm{kcal} / \mathrm{mol}$. At $600 \mathrm{~K}$, $-\Delta\left(G-H_{298}\right) / T=44.0 \mathrm{cal} / \mathrm{mol} \cdot \mathrm{K}$, based on the adjusted $-\left(\mathrm{G}-\mathrm{H}_{298}\right) / \mathrm{T}$ for $\mathrm{UF}_{5}(\mathrm{~g}), \mathrm{S}^{\circ} \mathrm{UF}_{5}(\mathrm{c}, \alpha)=47.7$ and an estimate for $-\left(\mathrm{G}-\mathrm{H}_{298} / \mathrm{T}\right) 600 \mathrm{~K}$ for UF ${ }_{5}(c, \approx)$. This $\Delta H^{\circ}{ }_{\text {subl }}$ results in $\Delta \mathrm{HF}^{\circ} \approx-462 \mathrm{kcal} / \mathrm{mol}$ for $\mathrm{UF}_{5}(\mathrm{~g})$ in agreement with the Hildenbrand measurements.

The Gibbs energy of formation has been calculated from $\Delta \mathrm{HF}^{\circ}$ and $\triangle \mathrm{Sf}^{\circ}$. $-45-$ 
The $\mathrm{S}^{0}, \mathrm{C}_{\mathrm{P}}^{0}$ and $\left(\mathrm{H}-\mathrm{H}_{0}\right)_{\mathrm{T}}$ values tabulated by Brickwedde et al. (1948) from their $C_{p}$ measurements on the crystal and liquid $(14-370 \mathrm{~K})$ are accepted. These measurements also define the triple point $(337.20 \mathrm{~K})$ and $\Delta \mathrm{H}_{\text {fusion }}=4.588 \pm 0.045 \mathrm{kcal} / \mathrm{mol}$.

In addition, there are measurements by Llewellyn (1953) in the range $213-373 \mathrm{~K}$.

The $\Delta \mathrm{Hf}^{\circ} \mathrm{UF}_{6}(\mathrm{c})$ has recently been redetermined by Johnson (1977) by direct fluorination of $U(c)$ to be $-525.13 \pm 0.44 \mathrm{kcal} / \mathrm{mol}$. Although still to be considered preliminary, this new determination confirms the value $=-525.1 \pm 0.5 \mathrm{kcal} / \mathrm{mol}$ recommended by Parker (1976b)from the key network analyses and the $\mathrm{UO}_{3}(c, \gamma)-\mathrm{UF}_{6}(\mathrm{c})-\mathrm{HF}(\mathrm{aq})-\mathrm{UO}_{2} \mathrm{~F}_{2}(\mathrm{c})$ cycles. These values supercede the value $-522.6 \pm 0.4 \mathrm{kcal} / \mathrm{mol}$ that had been considered to be definitive.

The analysis which indicated that the value $-522.6 \mathrm{kcal} / \mathrm{mol}$ for $\mathrm{UF}_{6}(\mathrm{c})$ was questionable and that a direct redetermination was needed to substantiate the indirect value, $-525.1 \mathrm{kcal} / \mathrm{mol}$, is presented historically in order to indicate how values considered reliable become suspect through a detailed analysis of the network. The analysis includes much of the preliminary evaluation of $\Delta \mathrm{Hf}^{\circ} \mathrm{UO}_{2} \mathrm{~F}_{2}$ (c) and $\triangle \mathrm{HF}^{\circ} \mathrm{UO}_{2} \mathrm{~F}_{2}$ (aq, in $\mathrm{HF}$ ) which brought the problem into focus. A. The Initially Accepted $\Delta \mathrm{Hf}^{\circ} \mathrm{UF}_{6}(\mathrm{c})$ and $\Delta \mathrm{Hf}^{\circ} \mathrm{UF}_{6}(\mathrm{~g})$

There were two determinations of the enthalpy of fluorination of $\mathrm{U}(\mathrm{c})$ to $\mathrm{UF}_{6}(\mathrm{c})$ and $\mathrm{UF}_{6}(\mathrm{~g})$ that were in good agreement with one another and were considered definitive for $\Delta H f^{\circ} \mathrm{UF}_{6}(\mathrm{c})$ and $\Delta H f^{\circ} \mathrm{UF}_{6}(\mathrm{~g})$. 
The first of these is by Settle et al. (1963) using bomb calorimetry

$$
\mathrm{U}(\mathrm{c})+3 \mathrm{~F}_{2}(\mathrm{~g}) \rightarrow \mathrm{UF}_{6}(\mathrm{c}) ; \Delta \mathrm{H}_{1}=-522.64 \pm 0.43 \mathrm{kcal} / \mathrm{mol}
$$

Hayman (1967) in a flow calorimeter obtained:

$$
\mathrm{U}(\mathrm{c})+3 \mathrm{~F}_{2}(\mathrm{~g}) \rightarrow \mathrm{UF}_{6}(\mathrm{~g}) ; \Delta \mathrm{H}_{2}=-510.47 \pm 0.64 \mathrm{kcal} / \mathrm{mol}
$$

From the analysis of the vapor pressure measurements (see $U_{6}(g)$ ):

$$
\mathrm{UF}_{6}(\mathrm{c}) \rightarrow \mathrm{UF}_{6}(\mathrm{~g}) ; \Delta \mathrm{H}_{3}^{\circ}=11.85 \pm 0.10 \mathrm{kcal} / \mathrm{mol}
$$

so that $\Delta H_{1}^{\circ}=-522.32 \pm 0.65 \mathrm{kcal} / \mathrm{mol}$ from Hayman's data.

These measurements led to the accepted $\Delta \mathrm{Hf}^{\circ} \mathrm{UF}_{6}(\mathrm{c})=-522.6 \pm 0.4$ and $\Delta H^{\circ} \mathrm{UF}_{6}(g)=-522.6+11.85=-510.75 \pm 0.4 \mathrm{kcal} / \mathrm{mol}$.

B. The Inconsistency in Paths and How it Affected $\Delta \mathrm{Hf}^{\circ} \mathrm{UO}_{2} \mathrm{~F}_{2}(\mathrm{c})$ and $\triangle \mathrm{Hf}^{\circ} \mathrm{UO}_{2} \mathrm{~F}_{2}$ (in HF)

The analysis of the data on the $\Delta H f^{\circ} \mathrm{UO}_{2} F_{2}$ (c) involves the $\triangle H f$ of the aqueous species. The measurements on the reaction of $\mathrm{UO}_{3}(c, y)$ in $\mathrm{HF}(\mathrm{aq})$ to form a species for convenience called $\mathrm{UO}_{2} \mathrm{~F}_{2}$ (aq, in $\mathrm{HF}$ ) will be cited first. The measured reactions are of the form: $\mathrm{UO}_{3}(\mathrm{c}, \gamma)+2 \mathrm{HF}(\mathrm{aq}$, in excess $) \rightarrow \mathrm{UO}_{2} \mathrm{~F}_{2}(\mathrm{aq}$, in $\mathrm{HF})+\mathrm{H}_{2} \mathrm{O}(\mathrm{aq}$, in $\mathrm{HF})$ Since all the measurements on the $\mathrm{\Delta H}_{\mathrm{r}}$ of $\mathrm{UO}_{3}(c, \gamma)$ were made in excess $\mathrm{HF}$ of varying concentration and in varying $\mathrm{UO}_{3} / \mathrm{HF}$ ratios we have corrected for the dilution of the excess HF in the final solution, either by using the appropriate $\varphi_{L}^{*}$ values for the initial and final concentrations, or by using the differentials $\overline{\mathrm{L}}_{2}{ }^{*}$ and $\overline{\mathrm{L}}_{1}$ if there is no appreciable concentration change for HF(aq).

\footnotetext{
All values listed by Parker et al. (1976) for the integral and differential $\triangle H f^{\prime} s \mathrm{HF}\left(\mathrm{nH}_{2} \mathrm{O}\right)$ should be made more negative by 0.07 $\mathrm{kcal} / \mathrm{mol}$. The value listed for $\triangle \mathrm{Hf}^{\circ} \mathrm{HF}(\mathrm{aq}$, std. state) $=-80.15$ $\mathrm{kcal} / \mathrm{mol}$ is correct.
} 


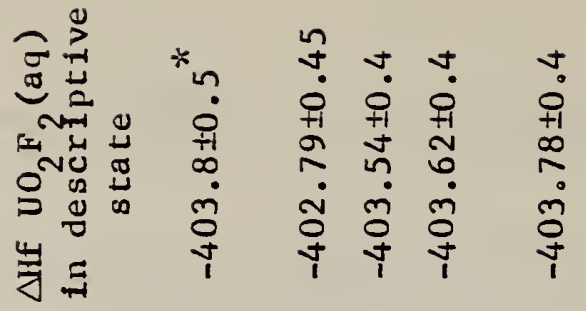

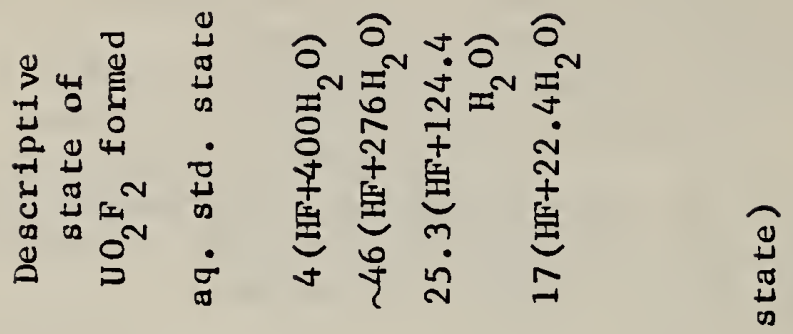

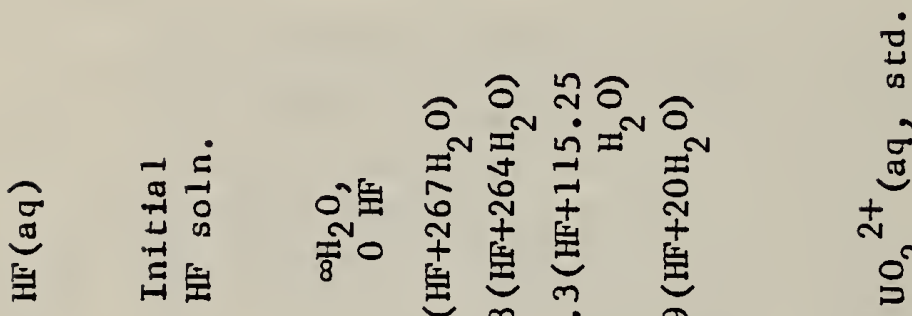

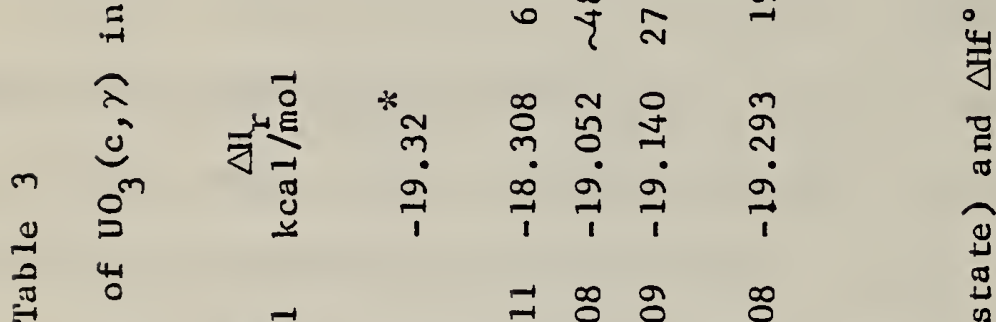

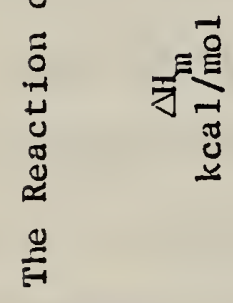

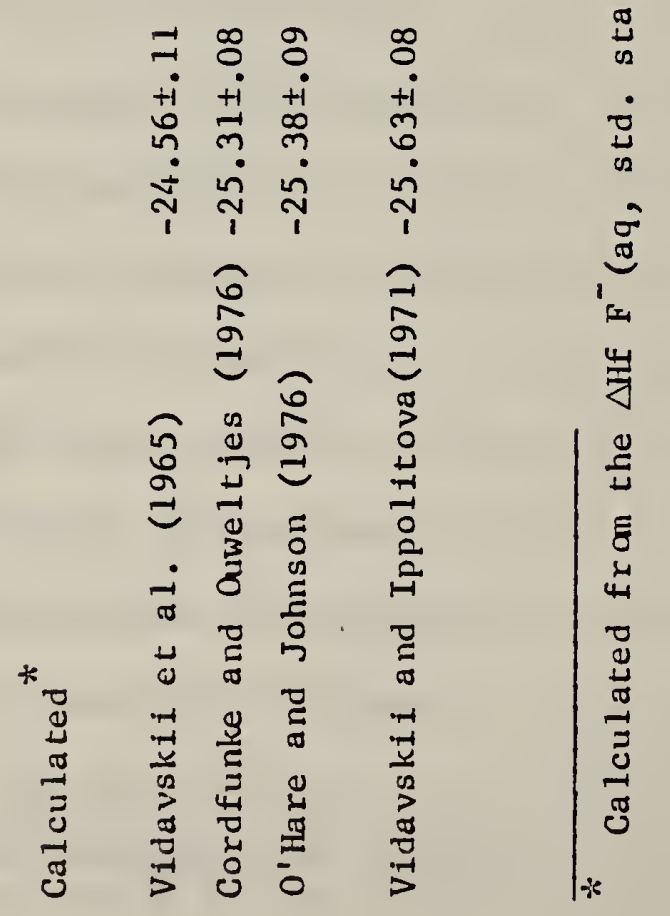


Table 3 shows the measured $\Delta \mathrm{H}_{\mathrm{m}}$ and the corrected $\Delta{ }_{r}$ for the reaction,

$$
\mathrm{UO}_{3}(\mathrm{c}, \gamma)+2 \mathrm{HF}(\mathrm{aq} \text {, std. state }) \rightarrow \mathrm{H}_{2} \mathrm{O}(1)+\mathrm{UO}_{2} \mathrm{~F}_{2}(\mathrm{aq} \text {, in } \mathrm{HF}) \text {, }
$$

the initial composition of the HF solution, the descriptive state for the $\mathrm{UO}_{2} \mathrm{~F}_{2}$ in the final solution and the calculated $\triangle \mathrm{Hf} \mathrm{UO}_{2} \mathrm{~F}_{2}$ for that state.

As can be seen, the results are in good agreement with one another, although the $\Delta H f$ calculated from Vidavskii et al. (1965) is 0.75 to $1.0 \mathrm{kcal} / \mathrm{mol}$ more positive than the others. The solution is also more concentrated with respect to the $\mathrm{UO}_{2} \mathrm{~F}_{2}$.

Similarly, information on $\triangle H f \mathrm{UO}_{2} \mathrm{~F}_{2}$ (aq, in $H F$ ) from the reaction of $\mathrm{UF}_{6}(\mathrm{c})$ in $\mathrm{H}_{2} \mathrm{O}(1)$ or in a solution of $\mathrm{HF}\left(\mathrm{a}_{\mathfrak{l}}\right)$ may be obtained. The measured reactions are of the form:

$$
\begin{aligned}
\mathrm{UF}_{6}(\mathrm{c})+2 \mathrm{H}_{2} \mathrm{O}(1) \text { or }(\text { in } \mathrm{HF} \text { soln. })-\mathrm{UO}_{2} \mathrm{~F}_{2}(\mathrm{aq}, \text { in } \mathrm{HF} & \text { soln. }) \\
& +4 \mathrm{HF} \text { (soln.) }
\end{aligned}
$$

The reactions have been corrected where necessary to $298 \mathrm{~K}$ and to the form :

$$
\mathrm{UF}_{6}(\mathrm{c})+2 \mathrm{H}_{2} \mathrm{O}(1)-\mathrm{UO}_{2} \mathrm{~F}_{2}(\mathrm{aq} \text {, in } \mathrm{HF})+4 \mathrm{HF} \text { (ac, std. state) }
$$

by correcting as for the reaction of $\mathrm{UO}_{3}(c, \gamma)$ in a solution of $\mathrm{HF}$.

Table 4

The Reaction of $\mathrm{UF}_{6}(\mathrm{c})$ in $\mathrm{H}_{2} \mathrm{O}$

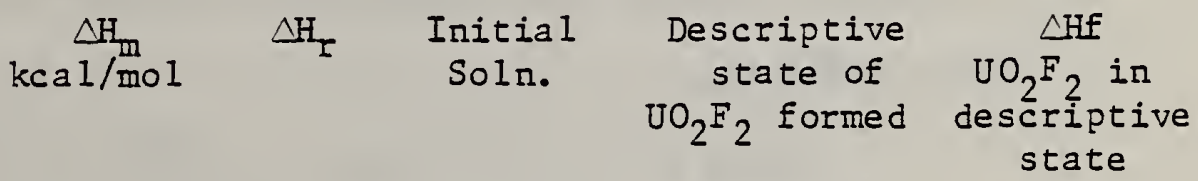

$$
\begin{aligned}
& \begin{array}{cccccc}
\text { Popov et al. } & -49.73^{*} & -61.874 & 1602 \mathrm{H}_{2} \mathrm{O} & 4\left(\mathrm{HF}+400 \mathrm{H}_{2} \mathrm{O}\right) & -400.50 \\
(1957) & \pm 0.30 & & & & \pm 0.8
\end{array} \\
& \text { O'Hare and } \quad-49.918 \quad-62.35 \quad 21.33(\mathrm{HF}+25.33(\mathrm{HF}+\quad-400.98 \\
& \begin{array}{lllll}
\text { Johns on }(1976) & \pm 0.07 & \left.147.80 \mathrm{H}_{2} \mathrm{O}\right) & \left.124.4 \mathrm{H}_{2} \mathrm{O}\right) & \pm 0.75
\end{array}
\end{aligned}
$$

*Corrected from $\Delta H_{m}=-50.22 \div 0.30$ at $305 \mathrm{~K}$ assuming $\Delta C_{p}=-70 \mathrm{cal} / \mathrm{mol} \cdot \mathrm{K}$ 
The two values are in good agreement with one another, and show the same effect as noted earlier, but the values calculated from the two tables differ by $\sim 2.5 \mathrm{kcal} / \mathrm{mol}$.

$\begin{array}{cccc}\Delta \mathrm{Hf}_{\mathrm{UO}} \mathrm{F}_{2}(\mathrm{aq}, \text { in } \mathrm{HF}) & \text { Descriptive } & \begin{array}{c}\text { Difference } \\ \text { in Paths }\end{array} \\ \text { from } \mathrm{UF}_{6} & \text { from } \gamma \mathrm{UO}_{3}(\mathrm{c}) & \text { State } & \mathrm{UF}_{6}-\mathrm{UO}_{3} \\ -400.50 & -402.79 & 4\left(\mathrm{HF}+400 \mathrm{H}_{2} \mathrm{O}\right) & 2.29 \\ -400.98 & -403.62 & 25.33\left(\mathrm{HF}+124.4 \mathrm{H}_{2} \mathrm{O}\right) & 2.64\end{array}$

The following measurements have been made on the $\Delta \mathrm{H}_{\text {soln. }} \mathrm{UO}_{2} \mathrm{~F}_{2}$ (c) in HF and in $\mathrm{H}_{2} \mathrm{O}(1)$ corrected to 298 where necessary.

Suponitskii et al. (1971)

Popov et al. (1957)

Cordfunke and Ouweltjes (1976)

$$
\underset{\mathrm{kca} 1 / \mathrm{mol}}{\triangle \mathrm{H}} \sin
$$$$
-7.12
$$$$
-7.89 \pm 0.2^{*}
$$$$
-8.10 \pm 0.05
$$

Solution

$$
571 \mathrm{H}_{2} \mathrm{O}
$$$$
4\left(\mathrm{HF}+40 \mathrm{H}_{2} \mathrm{O}\right)
$$

$47.6\left(\mathrm{HF}+264 \mathrm{H}_{2} \mathrm{O}\right)$

These values are also in agreement with one another. Obviously the values calculated for $\Delta \mathrm{Hf}^{\circ} \mathrm{UO}_{2} \mathrm{~F}_{2}(\mathrm{c})$ from the two available paths will reflect the $2.5 \mathrm{kcal}$ discrepancy, i.e. $\Delta \mathrm{Hf}^{\circ} \mathrm{UO}_{2} \mathrm{~F}_{2}(\mathrm{c})=-402.79$ $+7.89=-394.90 \pm 0.50 \mathrm{kcal} / \mathrm{mol}$ and $-403.54+8.10=-395.44 \pm 0.40$ $\mathrm{kcal} / \mathrm{mol}$ from the $\mathrm{UO}_{3}(\mathrm{c}, y)$ path and the appropriate $\Delta \mathrm{H}$ soln $\mathrm{UO}_{2} \mathrm{~F}_{2}(\mathrm{c})$, and $\triangle \mathrm{Hf}^{\circ} \mathrm{UO}_{2} \mathrm{~F}_{2}(\mathrm{c})=-400.50+7.89=-392.61 \pm 0.85 \mathrm{kcal} / \mathrm{mol}$ from the $\mathrm{UF}_{6}(\mathrm{c})$ path and the appropriate $\Delta \mathrm{H}_{\text {soln }} \mathrm{UO}_{2} \mathrm{~F}_{2}(\mathrm{c})$.

At this point it is essential to explore the possible causes of the difference.

1. There is a major error in either the experimental measurements involving the reaction of $\mathrm{UF}_{6}(c)$ or those of $\mathrm{UO}_{3}(c, \gamma)$. This is

$\overline{{ }^{*} \text { Corrected from } \Delta \mathrm{H}_{\text {soln }}}=-8.10$ at $305 \mathrm{~K}$ assuming $\Delta \mathrm{C}_{\mathrm{p}}=-30 \mathrm{cal} / \mathrm{mol} \cdot \mathrm{K}$. 
highly unlikely since the agreement within each set (differing in their origin) is rood.

2. The $\mathrm{UO}_{3}(c, \gamma)$ used for the measurements is not the same form as that for which $\Delta \mathrm{Hf}^{\circ}=-292.5 \pm 0.3$. However, O'Hare confirmed that the sample of $\mathrm{UO}_{3}(c, \gamma)$ used by O'Hare and Johns on (1976) was the same as that used by Fitzgibbon et a1. (1967) in their determination of $\Delta \mathrm{Hf}^{\circ} \mathrm{UO}_{3}(c, \gamma)$ fram solution calorimetry involving $\mathrm{UO}_{3}(\mathrm{c}, \gamma), \mathrm{UO}_{2}(\mathrm{c})$ and $\mathrm{U}_{3} \mathrm{O}_{8}$ (c) since they confirmed these solution measurements.

3. The value used for $\mathrm{UO}_{3}(c, \gamma)=-292.5 \pm 0.3 \mathrm{kcal} / \mathrm{mole}$ is too negative by $2.5 \mathrm{kcal} / \mathrm{mol}$. This does not seem possible unless a corresponding change is made in $\mathrm{UO}_{2}(\mathrm{c})$ and an even larger change is made in $\mathrm{U}_{3} \mathrm{O}_{8}(\mathrm{c})$. If $\mathrm{UO}_{2}(\mathrm{c})$ and $\mathrm{UO}_{3}(c, y)$ were changed significantly the good agreement obtained for the $\Delta \mathrm{Hf}^{\circ}$ values for (1) $\mathrm{UCl}_{4}$ (c) [only partly dependent on $\left.\Delta \mathrm{Hf} \mathrm{UO}_{2}(\mathrm{c})\right]$, (see section on $\mathrm{UCl}_{4}(\mathrm{c})$ );

(2) $\mathrm{UO}_{2} \mathrm{Cl}_{2}$ (c) [partly dependent on $\mathrm{UCl}_{4}$ (c) and partly dependent on $\left.\mathrm{UO}_{3}(c, \gamma)\right]$, (see section on $\mathrm{UO}_{2} \mathrm{Cl}_{2}(c)$ ); and (3) $\mathrm{UO}_{2}{ }^{2+}$ (aq, std. state) [partly dependent on $\mathrm{UO}_{2} \mathrm{Cl}_{2}$ (c) and partly dependent on $\mathrm{UO}_{2}\left(\mathrm{NO}_{3}\right)_{2} \cdot 6 \mathrm{H}_{2} \mathrm{O}(\mathrm{c})$ which is completely dependent on $\left.\mathrm{UO}_{3}(c, \gamma)\right]$, (see Fuger and Detting (1976)) would disappear.

4. The value used for $U_{6}$ (c) should be made more negative than -522.6 by this $2.5 \mathrm{kcal} / \mathrm{mol}$. As shown in $A$ on the $\Delta \mathrm{Hf}^{\circ}{ }^{\circ} \mathrm{s}$ for $\mathrm{UF}_{6}(\mathrm{c})$ and $\mathrm{UF}_{6}(\mathrm{~g})$, there is confimation for $-522.6 \mathrm{kcal} / \mathrm{mol}$. However, a more negative value for $\mathrm{UF}_{6}(\mathrm{c})$ and $\mathrm{UF}_{6}(\mathrm{~g})$ would lower the value for $\triangle \mathrm{H}^{\circ}$ subl. $U(c)$ derived from $U N(c)$ and US(c) and would bring them into better agreement with the accepted $\Delta \mathrm{H}^{\circ}$ subl $=127 \mathrm{kcal} / \mathrm{mol}$ (Detting et al. (1976)). 
5. Neither the $\Delta \mathrm{Hf}^{\circ} \mathrm{UO}_{3}(\mathrm{c}, y)$ nor the $\Delta \mathrm{Hf}^{\circ} \mathrm{UF}_{6}(\mathrm{c})$ are seriously in error, but the auxiliary values for $\triangle H f H F(a q)$ are. Since the $\mathrm{UF}_{6}(\mathrm{c})-\mathrm{UO}_{3}(\mathrm{c}, y)$ relation involves six $\mathrm{HF}(\mathrm{aq})$, this shift of $0.4 \mathrm{kcal} / \mathrm{mol} \mathrm{HF}$ would account for the discrepancy in paths. However, the $\triangle H F f F\left(a_{q}\right)$ values listed by Parker et al. (1976) from the Johnson et al. (1973) determinations are consistent with the CODATA (1975) $\triangle \mathrm{HF}^{\circ} \mathrm{F}^{-}$(aq, std. state) $=$ $-80.15 \pm 0.16 \mathrm{kcal} / \mathrm{mol}$ which was fixed from various cycles, five of which were in agreement (within $\pm 0.1 \mathrm{kcal}$ ).

6. None of the above, but an erroneous assumption is being made.

The first three possibilities are at present rejected. It is more difficult to assess the remaining three; however, these 3 possibilities all involve the reaction of $\mathrm{UF}_{6}(c)$, either because the accepted $\Delta \mathrm{Hf}^{\circ}$ $\mathrm{UF}_{6}(c)$ is erroneous, or because of the greater dependency on the value for $\Delta H f^{\circ} F^{-}$(aq, std. state), or because the assumption on final solutions is not warranted.

The better path, then, to $\mathrm{UO}_{2} \mathrm{~F}_{2}(\mathrm{c})$ and $\mathrm{UO}_{2} \mathrm{~F}_{2}$ (aq, in $\mathrm{HF}$ ) is from the relationship to $\mathrm{UO}_{3}(c, \gamma)$, whick results in $-394.90 \pm 0.5$ and $-395.44 \pm 0.4 \mathrm{kcal} / \mathrm{mol}$ for $\Delta \mathrm{Hf}^{\circ} \mathrm{UO}_{2} \mathrm{~F}_{2}(\mathrm{c})$ rather than from the $\mathrm{UF}_{6}(\mathrm{c})$ path which results in $-392.6 \pm 0.85 \mathrm{kcal} / \mathrm{mol}$.

C. The decision to change the $\Delta \mathrm{HF}^{\circ}{ }^{\prime} \mathrm{s} \mathrm{UF}_{6}(\mathrm{c})$ and $\mathrm{UF}_{6}(\mathrm{~g})$

As is indicated in $B$, either the $\Delta \mathrm{Hf}^{\circ} \mathrm{UF}_{6}$ is suspect or to a lesser extent $\triangle H F H F(a q$, std. state). However, if one goes through the uranium key network the more positive $\triangle H^{\circ}{ }^{\circ} \mathrm{HF}$ (aq, std. state) $(=-79.75 \mathrm{kcal} / \mathrm{mol})$ required here would not resolve other inconsistencies. (See $\mathrm{UF}_{3}$ (c) and $\mathrm{UF}_{4}(\mathrm{c})$ ) where a more negative $\triangle H \mathrm{H}^{\circ} \mathrm{HF}$ (aq, std. state) would be 
required to resolve the inconsistencies. In addition, on a practical note, many more new cycles would have to be considered before one could say with certainty that the CODATA $\triangle H F H F(a q$, std. state) is too negative by $0.4 \mathrm{kcal} / \mathrm{mol}$ (the $\mathrm{UF}_{6}(\mathrm{c})-\mathrm{UO}_{3}(\mathrm{c}, y)$ cycle from the combination of Popov et al. (1957) and Vidavskii et al. (1965) had been considered by the CODATA task force).

The most likely values then, by the process of elimination, are $\Delta \mathrm{Hf}^{\circ}$ 's $\mathrm{UF}_{6}(\mathrm{c})$ and $\mathrm{UF}_{6}(\mathrm{~g})$. In order to substantiate this the following was done:

It was assumed that the fluorinations of $U(c)$ to $\mathrm{UF}_{6}(\mathrm{c})$ and $(\mathrm{g})$ were in error but that the $\Delta H^{\prime} s$ of fluorination of $U N(c)$, US(c) to $\mathrm{UF}_{6}$ were correct.

The high temperature decomposition reactions of US(c) and UN(c) were considered and the most reasonable reactions used. The $\Delta H f^{\circ}$ $U(g)=127_{-1}^{+2} \mathrm{kcal} / \mathrm{mol}$ from Oetting et al. (1976) was used in each reaction to obtain values for $\Delta H f^{\circ}$ of $U S(c)$ and $U N(c)$ which were then used in the fluorination reactions to obtain values for $\Delta \mathrm{HF}^{\circ} \mathrm{UF}_{6}(\mathrm{c})$ and $\Delta \mathrm{Hf}^{\circ} \mathrm{UF}_{6}(\mathrm{~g})$.

The reactions are:

$$
\mathrm{UN}(\mathrm{c})-\mathrm{U}(\mathrm{g})+1 / 2 \mathrm{~N}_{2}(\mathrm{~g}) ; \Delta \mathrm{H}^{\circ}{ }_{1}=200.7 \pm 1.0 \mathrm{kcal} / \mathrm{mol}
$$
(avg. of $2 \mathrm{nd}$ and $3 \mathrm{rd}$ law) from Hoenig (1971), so that $\Delta H^{\circ}{ }^{\circ} \mathrm{UN}(\mathrm{c})=-73.7 \pm 1.8 \mathrm{kcal} / \mathrm{mol}$ and $\angle H f^{\circ}$ 


$$
\begin{aligned}
& \mathrm{UN}_{0.9957}=-73.6 \pm 1.8 \mathrm{kcal} / \mathrm{mol} . \\
& \mathrm{UN}_{0.9957}(\mathrm{c})+3 \mathrm{~F}_{2}(\mathrm{~g})-\mathrm{UF}_{6}(\mathrm{c})+0.9957 / 2 \mathrm{~N}_{2}(\mathrm{~g}) ; \\
& \Delta \mathrm{H}_{2}=-451.86 \pm 0.3 \mathrm{kcal} / \mathrm{mol}
\end{aligned}
$$

from O'Hare et al. (1967) (corrected for composition), so that $\Delta H^{\circ}{ }^{\circ}$ $\mathrm{UF}_{6}(\mathrm{c})=-525.5 \pm 1.9 \mathrm{kcal} / \mathrm{mol}$.

$$
\mathrm{US}(\mathrm{c}) \rightarrow \mathrm{U}(\mathrm{g})+\mathrm{S}(\mathrm{g}) ; \Delta \mathrm{H}_{2}=269.6 \pm 2.0 \mathrm{kcal} / \mathrm{mol} \text { from Nater (1969) }
$$

so that $\triangle H f^{\circ}$ US $(\mathrm{c})=-76.4 \pm 2.5$ and $\triangle \mathrm{Hf}^{\circ} \mathrm{US}_{1.011}(\mathrm{c})=-76.8 \pm 2.5 \mathrm{kcal} / \mathrm{mol}$.

$$
\begin{aligned}
\mathrm{US}_{1.011}(\mathrm{c}) & +6.033 \mathrm{~F}_{2}(\mathrm{~g}) \rightarrow \mathrm{UF}_{6}(\mathrm{~g})+1.011 \mathrm{SF}_{6}(\mathrm{~g}) ; \\
\Delta \mathrm{H}_{4} & =-732.59 \pm 2.0 \mathrm{kcal} / \mathrm{mol} \text { from } \mathrm{O}^{\prime} \text { Hare et al. (1967) (4) }
\end{aligned}
$$

with $\Delta \mathrm{Hf}^{\circ} \mathrm{UF}_{6}(\mathrm{~g})=-514.4 \pm 3.2 \mathrm{kcal} / \mathrm{mol}$ and $\Delta \mathrm{Hf}^{\circ} \mathrm{UF}_{6}(\mathrm{c})=-526.3 \pm 3.2$ kcal/mol. These two paths lend support to more negative values for $\Delta H f^{\circ} \mathrm{UF}_{6}(\mathrm{c})$ and $\Delta H \mathrm{ff}^{\circ} \mathrm{UF}_{6}(\mathrm{~g})$. These are obtained from the $\mathrm{UF}_{6}-\mathrm{UO}_{3}$ cycles, so that $\Delta \mathrm{Hf}^{\circ} \mathrm{UF}_{6}(\mathrm{c})=-522.6-2.29=-524.89 \pm 0.6 \mathrm{kcal} / \mathrm{mol}$ from the Popov-Vidavskii cycle and $-522.6-2.64=-525.24 \pm 0.5 \mathrm{kcal} / \mathrm{mol}$ from the $O^{\prime}$ Hare and Johnson cycle, resulting in a selected $\Delta H^{\circ}{ }^{\circ} F_{6}(c)$ $=-525.1 \pm 0.5 \mathrm{kcal} / \mathrm{mol}$.

D. Confirmation From the Direct Enthalpy of Fluorination Obviously confirmation for this new value was needed. The new measurements of Johnson (1977) on the direct fluorination to $\mathrm{UF}_{6}(\mathrm{c})$ cited previously $=-525.13 \pm 0.44^{*} \mathrm{kcal} / \mathrm{mol}$ lends support to the indirect value**.

\footnotetext{
A recalculation by Johnson (1979) using the values for the $\Delta H f^{\circ}$ 's for $\mathrm{UF}_{3}(\mathrm{c})$ and $\mathrm{UF}_{4}(\mathrm{c})$ and the $\Delta \mathrm{H}^{\circ}$ subl $\mathrm{UF}_{6}(\mathrm{c})$ selected in this evaluation results in $\Delta \mathrm{Hf}^{\circ} \mathrm{UF}_{6}(\mathrm{c})=-525.28 \pm 0.44 \mathrm{kcal} / \mathrm{mol}$.

$* *$

One should also note that the new direct determination lends support to the CODATA $\triangle H f^{\circ} \mathrm{HF}\left(\mathrm{aq}\right.$, std. state) and $\Delta \mathrm{Hf}^{\circ} \mathrm{F}^{-}$(aq, std. state) $=-80.15 \mathrm{kcal} / \mathrm{mol}$.
} 
We can now with certainty assign $\Delta \mathrm{Hf}^{\circ} \mathrm{UF}_{6}(\mathrm{c})=-525.1 \pm 0.4 \mathrm{kcal} / \mathrm{mol}$ and $\Delta$ Hf $^{\circ} \mathrm{UF}_{6}(\mathrm{~g})=-525.1+11.85=-513.25 \pm 0.4 \mathrm{kcal} / \mathrm{mol}$.

There is at present no explanation for the two earlier direct fluorination reactions, in agreement with one another, being in error.

The Gibbs energy of formation has been calculated from the $\Delta H f^{\circ}$ and the $\Delta S f^{\circ}$. 
$\underline{\mathrm{UF}}{ }_{6}(\mathrm{~g})$

The $\Delta \mathrm{H}^{\circ}$ subl $=11.85 \pm 0.10 \mathrm{kcal} / \mathrm{mol}$ and the $\Delta G^{\circ}$ subl $=1.14$ $\mathrm{kcal} / \mathrm{mol}$ result in $\Delta \mathrm{S}^{\circ}$ subl. $=35.95 \pm 0.3 \mathrm{cal} / \mathrm{mol} \cdot \mathrm{K}$ which leads to $\mathrm{S}^{\circ}$ $\mathrm{UF}_{6}(\mathrm{~g})=90.3 \pm 0.45 \mathrm{cal} / \mathrm{mol} \cdot \mathrm{K}$.

The thermal functions for the ideal gas may also be calculated from spectroscopic data. The frequency assignment by Claasen (1959) $667(1), 535(2), 623(3), 181(3), 202(3), 140(3) \mathrm{cm}^{-1}$ based on the measurements of Gaunt (1953), Claasen et al. (1956), Burke et al. (1952), and Bigeleisen et a1. (1948), for the octahedron (symmetry = 24), with r-U-F 1.999A from Seip (1965) results in $S^{\circ}=90.23 \mathrm{cal} / \mathrm{mol} \cdot \mathrm{K}$ in excellent agreement with the experimentally derived $S^{\circ}$.

The more recent assignment of McDowell et al. (1974) 672(1), $540(2), 634(3), 186(3), 200(3), 143(3) \mathrm{cm}^{-1}$ results in $\mathrm{S}^{\circ}=89.93$ cal/mol $\cdot \mathrm{k}$.

A table of thermal functions based on Claasen et al.'s (1956) assignment is presented here (Section V).

The $\Delta H f^{\circ}$ of $\mathrm{UF}_{6}(\mathrm{~g})$ is derived from the selected $\Delta \mathrm{H}^{\circ}$ subl $=$ $11.85 \pm 0.10 \mathrm{kcal} / \mathrm{mol}$ for:

$$
\mathrm{UF}_{6}(\mathrm{c}) \rightarrow \mathrm{UF}_{6}(\mathrm{~g}) \text {. }
$$

This is obtained from both the calorimetric determinations of $\Delta H^{\circ}$ vap (277-363 K) of Masi (1949) and those calculated from the various vapor pressure measurements, all in excellent agreement. This results in $\Delta \mathrm{Hf}^{\circ} \mathrm{UF}_{6}(\mathrm{~g})=-513.25 \pm 0.4 \mathrm{kcal} / \mathrm{mol}$. 
As indicated under $\mathrm{UF}_{6}(\mathrm{c})$, Hayman (1967) obtained $\Delta \mathrm{H}_{2}=-510.5 \pm 0.7$ $\mathrm{kcal} / \mathrm{mol}$ for:

$$
\mathrm{U}(\mathrm{c})+3 \mathrm{~F}_{2}(\mathrm{~g}) \rightarrow \mathrm{UF}_{6}(\mathrm{~g})
$$

This has been shown to be in error.

The $\Delta G^{\circ}{ }_{1}=1.14 \mathrm{kcal} / \mathrm{mol}$, result's in $\Delta G f^{\circ} U F_{6}(g)=-493.26$ $\mathrm{kcal} / \mathrm{mol}$.

The various vapor pressure measurements on the solid and liquid are in good agreement and can be represented by the equations of Oliver et al.(1953):

$$
\begin{aligned}
& U F_{6}(\mathrm{c}) \\
& \log P(\mathrm{~atm})=3.50282+0.0075377 t-942.76 /(t+183.416) \\
& (273-337 \mathrm{~K})
\end{aligned}
$$

$\mathrm{UF}_{6}(1)$

$$
\begin{gathered}
\log P(a t m)=4.11383-1126.288 /(t+221.963) \\
(337-390 \mathrm{~K})
\end{gathered}
$$

$\mathrm{UF}_{6}(1)$

$$
\begin{gathered}
\log P(\mathrm{~atm})=4.80988-1683.165 /(t+302.148) \\
(390-500 \mathrm{~K})
\end{gathered}
$$

The triple point calculated here is $337.20 \mathrm{~K}$ with $\mathrm{P}(\mathrm{mm})=1139.6$.

This calculated triple point is in excellent agreement with that directly determined by Brickwedde et al. (1948) as $337.202 \mathrm{~K}$ with $\Delta H_{\text {fusion }}=4.588 \mathrm{kca} 1 / \mathrm{mol}, \Delta S^{\circ}=13.61 \mathrm{cal} / \mathrm{mol} \cdot \mathrm{K}$.

For $\mathrm{UF}_{6}(1) \rightarrow \mathrm{UF}_{6}(\mathrm{~g}):$

$$
\text { at } \mathrm{T}=337.202 \mathrm{~K} \quad \Delta \mathrm{H}_{\text {vap }}^{\circ}=6.84 \mathrm{kcal} / \mathrm{mol}
$$

The sublimation temperature (1 atm.) is at $329.69 \mathrm{~K}$. 
For convenience Masi's (1949) smoothed $\Delta \mathrm{H}^{\circ}$ vap for the condensed phases (273-370 K) are tabulated. These values are within $50 \mathrm{cal} / \mathrm{mol}$ of the recomended values given here.

\section{TABLE 5}

Enthalpies of Vaporization of $\mathrm{UF}_{6}$

$\mathrm{T}, \mathrm{K} \quad \mathrm{Ca} / \mathrm{HH}$

crysta 1

273.15

280

290

298.15

300

310

320

330

337.20

337.20

340

350

360

370
12,023

11,988

11,929

11,872

11,858

11,772

11,666

11,537

11,429

liquid

6859

6817

6671

6533

6404

See Rand and Kubaschewski (1963) for citations to the individua 1 investigations for the vapor pressure measurements. 


\section{$3.102 \mathrm{U}-\mathrm{F}-\mathrm{O}$ Compounds}

$\mathrm{UOF}{ }_{2}(\mathrm{c})$ and $U \mathrm{UFF}_{2} \cdot \mathrm{H}_{2} \mathrm{O}(\mathrm{c})$

$\mathrm{S}^{\circ} \mathrm{UOF}{ }_{2}(\mathrm{c})$ has been estimated as $28.5 \pm 1.0 \mathrm{cal} / \mathrm{mol} \cdot \mathrm{K}$ based on a comparison of the $\mathrm{S}^{\circ} \mathrm{s}$ of $\mathrm{UCl}_{4}(\mathrm{c}), \mathrm{UF}_{4}(\mathrm{c}), \mathrm{UOCl}_{2}(\mathrm{c}), \mathrm{UO}_{2} \mathrm{Cl}_{2}(\mathrm{c})$, $\mathrm{UO}_{2} \mathrm{~F}_{2}(\mathrm{c}), \mathrm{UO}_{2}(\mathrm{c})$, and $\mathrm{UO}_{3}(\mathrm{c})$. The $\mathrm{S}^{\circ} \mathrm{UOF}_{2} \cdot \mathrm{H}_{2} \mathrm{O}(\mathrm{c})$ is derived from the estimated $\Delta S_{5}$ disclizid in the following section.

Vdovenko et a1. (1967) isolated a black crystal hydrate which corresponded to $\mathrm{UOF}_{2} \cdot \mathrm{H}_{2} \mathrm{O}(\mathrm{c})$. In (1969) they measured its entha lpy of reaction in $\mathrm{HCl}(\mathrm{aq})$ at $293 \mathrm{~K}$. Their measured reactions are:

$$
\begin{array}{r}
\mathrm{UOF}{ }_{2} \cdot \mathrm{H}_{2} \mathrm{O}(\mathrm{c})+254 \mathrm{HCl}(\mathrm{aq})-\left[\mathrm{UF}_{2} \mathrm{Cl}_{2}+252 \mathrm{HCl}+2 \mathrm{H}_{2} \mathrm{O}\right] \mathrm{aq} ; \\
\Delta \mathrm{H}_{1}=-5.42 \pm 0.04 \mathrm{kcal} / \mathrm{mol} \\
{\left[\mathrm{UCl}_{4}+250 \mathrm{HCl}\right] \mathrm{aq}+2 \mathrm{HF}(\mathrm{aq})-\left[\mathrm{UF}_{2} \mathrm{Cl}_{2}+252 \mathrm{HCl}\right] \mathrm{aq} ;} \\
\Delta \mathrm{H}_{2}=-7.90 \pm 0.05 \mathrm{kcal} / \mathrm{mol}
\end{array}
$$

The concentrations used correspond to those used by Maltsev et al. (1960) in their determination of $\Delta \mathrm{Hf}^{\circ} \mathrm{UF}_{4} \cdot 2.5 \mathrm{H}_{2} \mathrm{O}(\mathrm{c})$ and use is made of the Maltsev et al. reaction:

$$
\mathrm{UCl}_{4}(\mathrm{c})+250 \mathrm{HCl}(\mathrm{aq})-\left[\mathrm{UCl}_{4}+250 \mathrm{HCl}\right] \mathrm{aq} ; \Delta \mathrm{H}_{3}=-43.47 \pm 0.10
$$

to complete the cycle. From these reactions the following summation is obtained:

$$
\begin{array}{r}
\mathrm{UCl}_{4}(\mathrm{c})+2 \mathrm{H}_{2} \mathrm{O}(\mathrm{aq})+2 \mathrm{HF}(40 \% \text { soln. })-\mathrm{UOF}_{2} \cdot \mathrm{H}_{2} \mathrm{O}(\mathrm{c})+4 \mathrm{HCl}(5 \mathrm{~N} \mathrm{HCl}) ; \\
\Delta \mathrm{H}_{4}=-46.68 \pm 0.2^{*} \mathrm{kcal} / \mathrm{mol} \mathrm{UCl}_{4}(\mathrm{c}) \text { (4) }
\end{array}
$$

From the individual reactions in the two papers involved it is clear that the $\triangle H f$ of the $H F 40 \%$ soln. $\left.H F \cdot 1.667 H_{2} O\right)$ to be used is an

Corrected to $298 \mathrm{~K}$, assuming $\Delta \mathcal{C}_{\mathrm{p}}=-145 \mathrm{cal} / \mathrm{mol} \cdot \mathrm{K}$. 
integral quantity $=-76.42 \mathrm{kcal} / \mathrm{mol}$ but the $\Delta \mathrm{Hf}^{\prime} \mathrm{s}$ of $\mathrm{HCl}$ and $\mathrm{H}_{2} \mathrm{O}$ in 5N HCl solution, $\mathrm{HCl}\left(\mathrm{IOH}_{2} \mathrm{O}\right)$, are differential quantities.

The resultant $\Delta \mathrm{Hf}^{\circ} \mathrm{UOF}_{2} \cdot \mathrm{H}_{2} \mathrm{O}(\mathrm{c})=-430.7 \pm 0.8 \mathrm{kcal} / \mathrm{mol}$.

In addition, the $\mathrm{H}_{2} \mathrm{O}$ vapor pressure $\left(283\right.$ to $363 \mathrm{~K}$ ) over $\mathrm{UOF}_{2} \cdot \mathrm{H}_{2} \mathrm{O}$ was determined by Vdovenko et al. (1969). For:

$$
\mathrm{UOF}_{2} \cdot \mathrm{H}_{2} \mathrm{O}(\mathrm{c}) \rightarrow \mathrm{UOF}_{2}(\mathrm{c})+\mathrm{H}_{2} \mathrm{O}(\mathrm{g}) \text {; }
$$

at $298 \mathrm{~K}$ they report a calculated $\Delta \mathrm{H}_{5}=11.1 \mathrm{kcal} / \mathrm{mol} \mathrm{H}_{2} \mathrm{O}(\mathrm{g})$

$$
\begin{aligned}
& \Delta G_{5}=2.82 \mathrm{kcal} / \mathrm{mol} \mathrm{H} \\
& \Delta S_{5}=27.8 \mathrm{cal}) \\
& \Delta \mathrm{cal} / \mathrm{mol} \cdot \mathrm{K}
\end{aligned}
$$

Use of the calculated $\Delta \mathrm{H}_{5}=11.1 \mathrm{kcal} / \mathrm{mol}$ results in $\Delta \mathrm{Hf}^{\circ} \mathrm{UOF}_{2}$ (c) $=-361.8 \mathrm{kcal} / \mathrm{mol}$. This would mean that for the reaction:

$$
\begin{gathered}
2 \mathrm{UOF}_{2}(\mathrm{c}) \rightarrow \mathrm{UO}_{2}(\mathrm{c})+\mathrm{UF}_{4}(\mathrm{c}) \\
\Delta \mathrm{H}>8 \mathrm{kcal} / \mathrm{mol} \mathrm{UF}_{4} \text { * and } \Delta \mathrm{G}>9 \mathrm{kcal} / \mathrm{mol} \mathrm{UF}_{4}
\end{gathered}
$$

This would indicate that the stability of $\mathrm{UOF}_{2}(\mathrm{c})$ is greater than that of $\mathrm{UOCl}_{2}$ (c) ( $\triangle \mathrm{H}$ and $\triangle G$ for the comparable chloride reaction are 7.2 and $7.4 \mathrm{kcal} / \mathrm{mol} \mathrm{UCl}_{4}$ (c), respectively). This is questionable. In addition the calculated $\Delta S$ and $\Delta H$ for reaction (5) are low. One would expect $\Delta S_{5}$ to be $\sim 35 \mathrm{e} . \mathrm{u}$. If the measured pressure at $298 \mathrm{~K}$ is used $\left(\Delta G^{\circ}{ }_{5}=2.82 \mathrm{kcal} / \mathrm{mol}\right)$ with the estimate $\Delta S_{5}=35 \mathrm{cal} / \mathrm{mol} \cdot \mathrm{K}$, $\Delta \mathrm{H}_{5}=13.3 \mathrm{kcal} / \mathrm{mol} \mathrm{H}_{2} \mathrm{O}(\mathrm{g})$. This results in $\Delta \mathrm{Hf}^{\circ} \mathrm{UOF}_{2}(\mathrm{c})=-359.6 \pm 2.5$ kcal and results in, for $(6), \Delta \mathrm{H}<6 \mathrm{kcal} / \mathrm{mol} \mathrm{UF}_{4}{ }^{*}$.

The Gibbs energies of formation have been calculated from the $\triangle H f^{\circ} ' s$ and $\triangle S f^{\circ} ' s$.

$* \Delta H>8$ and $\Delta H<6$ are used because of the uncertainty in the $\Delta H f^{\circ}$ $U F_{4}(c)$. 
$\mathrm{UO}_{2} \mathrm{~F}_{2}(\mathrm{c})$

Wacker and Cheney (1947) measured the heat capacity from $13 \mathrm{~K}$ to $418 \mathrm{~K}$. The tabulated $\mathrm{S}^{\circ}, \mathrm{C}_{\mathrm{p}}{ }^{\circ}$ and $\mathrm{H}-\mathrm{H}_{0}$ are obtained from their smoothed values. Kelley and King (1961) cite the above measurements in their tabulation; nowever, they report $\mathrm{S}^{\circ}{ }_{298}=33.40 \mathrm{cal} / \mathrm{mol} \cdot \mathrm{K}$. This appears to be an error in transcription.

Cordfunke et al. (1978) determined the high-temperature enthalpy from 375 to $811 \mathrm{~K}$ relative to $298 \mathrm{~K}$. The results are expressed as:

$$
\mathrm{H}_{\mathrm{T}}-\mathrm{H}_{298}=29.53 \mathrm{~T}+0.5833 \times 10^{-3} \mathrm{~T}^{2}+5.193 \times 10^{5} \mathrm{~T}^{-1}-10,598 \mathrm{cal} / \mathrm{mol}
$$

$$
(298-811 \mathrm{~K})
$$

This equation results in values for $\mathrm{H}_{\mathrm{T}}-\mathrm{H}_{298}$ in good agreement (lower by $\sim .03 \mathrm{kcal} / \mathrm{mol}$ at $400 \mathrm{~K}$ ) with those tabulated by Wacker and Cheney (1947) but leads to a calculated $\mathrm{C}_{\mathrm{p}}{ }^{\circ}$ at $298.15 \mathrm{~K} \sim 0.6 \mathrm{cal} / \mathrm{mol} \cdot \mathrm{K}$ lower than that obtained from the direct $\mathrm{C}_{\mathrm{p}}{ }^{0}$ determinations which are, at present, preferred for the low-temperature properties.

Purity of the Wacker and Cheney sample, however, may be the problem.

As indicated in the discussion of $\Delta \mathrm{Hf}^{\circ} \mathrm{UF}_{6}(\mathrm{c})$, from

$$
\mathrm{UO}_{3}(\mathrm{c}, \gamma)+2 \mathrm{HF}(\mathrm{aq} \text {, std. state }) \rightarrow \mathrm{UO}_{2} \mathrm{~F}_{2}(\mathrm{c})+\mathrm{H}_{2} \mathrm{O}(\mathrm{I})
$$

$\Delta \mathrm{Hf}^{\circ} \mathrm{UO}_{2} \mathrm{~F}_{2}(\mathrm{c})=-394.90 \pm 0.50 \mathrm{kcal} / \mathrm{mol}$ from the combination of the Popov et al. (1957) $\Delta \mathrm{H}_{\text {soln }} \mathrm{UO}_{2} \mathrm{~F}_{2}(\mathrm{c})$ in $4\left(\mathrm{HF}+400 \mathrm{H}_{2} \mathrm{O}\right)$ and the Vidavskii et al. (1965) $\Delta \mathrm{Hf}^{\circ} \mathrm{UO}_{2} \mathrm{~F}_{2}(\mathrm{aq})$ in the same final solution. Also $\Delta \mathrm{Hf^{ \circ }}$ $\mathrm{UO}_{2} \mathrm{~F}_{2}(\mathrm{c})=-395.44 \pm 0.35$ from the Cordfunke and Ouweltjes (1976) values. 
From the Popov et al. (1957) $\mathrm{UF}_{6}-\mathrm{UO}_{2} \mathrm{~F}_{2}$ cycle $\Delta \mathrm{Hf}^{\circ}=-403.0^{*}+$ $7.89=-395.11 \pm 0.6 \mathrm{kcal} / \mathrm{mol}$.

The selected value of $\Delta \mathrm{Hf}^{\circ} \mathrm{UO}_{2} F_{2}(\mathrm{c})=-395.2 \pm 0.3 \mathrm{kcal} / \mathrm{mol}$.

In addition to the measurements described above, Knacke et al. (1969) reported a $\Delta \mathrm{H}=90.7 \mathrm{kcal} / \mathrm{mol}_{\mathrm{UF}}(\mathrm{g})$ and $\Delta \mathrm{S}^{\circ}=62.3 \mathrm{cs}=1$ 'mol $\mathrm{UF}_{6}(\mathrm{~g})$ in the range $1033 \mathrm{~K}$ to $1073 \mathrm{~K}$ for the decomposition:

$$
3 \mathrm{UO}_{2} \mathrm{~F}_{2}(\mathrm{c}) \rightarrow 2 / 3 \mathrm{U}_{3} \mathrm{O}_{8}(\mathrm{c})+\mathrm{UF}_{6}(\mathrm{~g})+\mathrm{I} / 3 \mathrm{O}_{2}(\mathrm{~g})
$$

With a $\Delta C_{p}=-3.7 \mathrm{cal} / \mathrm{mol} \cdot \mathrm{K}, \Delta \mathrm{H}^{\circ}=94.0 \mathrm{kcal} / \mathrm{mol}$ and $\Delta \mathrm{S}^{\circ}=66 \mathrm{cal} / \mathrm{mol} \cdot \mathrm{K}$. This $\Delta \mathrm{H}$ results in $\Delta \mathrm{Hf}^{\circ} \mathrm{UO}_{2} \mathrm{~F}_{2}(\mathrm{c})=-392.3 \mathrm{kcal} / \mathrm{mol}$ and $\mathrm{S}^{\circ} \mathrm{UO}_{2} \mathrm{~F}_{2}(\mathrm{c})$ $=28.6 \mathrm{cal} / \mathrm{mol} \cdot \mathrm{K}$, in sharp disagreement with the measured low temperature value. In addition, if one uses the measured low temperature $\mathrm{S}^{\circ}$ 's and the $\Delta G^{\circ}$ at $1040 \mathrm{~K}$, the resultant $\Delta \mathrm{H}^{\circ}{ }_{298}=80.2 \mathrm{kcal} / \mathrm{mol}$ and $\Delta H f^{\circ}=-387.7 \mathrm{kcal} / \mathrm{mol}$, even further off. No weight can be given to these measurements. There is a possibility that the products of the decomposition are not as written.

The Gibbs energy of formation has been calculated from the accepted $\Delta H f^{\circ}$ and the $\Delta S f^{\circ}$.

*i.e., $-400.5-2.5$ where $-2.5=-525.1-522.6$. 
$\mathrm{UO}_{2} \mathrm{~F}_{2}(\mathrm{aq}$, in $\mathrm{HF})$

The various values for the $\Delta H f^{\circ} \mathrm{UO}_{2} \mathrm{~F}_{2}$ (aq, in $H F$ ) cited in the discussion under $\mathrm{UF}_{6}(\mathrm{c})$ from the $\Delta \mathrm{H}^{\circ}$ 's of reaction of $\mathrm{UF}_{6}, \gamma \mathrm{UO}_{3}$ and $\mathrm{UO}_{2} \mathrm{~F}_{2}(\mathrm{c})$ in $\mathrm{HF}$ can now be consolidated. The major effect appears to be the concentration of the HF solution.

Final smoothed values are:

$$
\begin{array}{cc}
\underset{\mathrm{SOln}}{\mathrm{kca} 1 / \mathrm{mol}} \mathrm{UO}_{2} \mathrm{~F}_{2}(\mathrm{c}) & \begin{array}{c}
\mathrm{UO}_{2} \mathrm{~F}_{2} \text { (solution) } \\
\mathrm{kcal} / \mathrm{mol}
\end{array} \\
-8.6 & -403.8 \\
-7.12 & -402.32 \\
-7.85 & -403.05 \\
-8.20 \pm .10 & -403.40 \\
-8.35 & -403.55 \\
-8.58 & -403.78
\end{array}
$$

Descriptive
State
aq. std. state
in $570 \mathrm{H}_{2} \mathrm{O}$
in $4\left(\mathrm{HF}+400 \mathrm{H}_{2} \mathrm{O}\right)$
in $47\left(\mathrm{HF}+276 \mathrm{H}_{2} \mathrm{O}\right)$
in $25\left(\mathrm{HF}+124.4 \mathrm{H}_{2} \mathrm{O}\right)$
in $17\left(\mathrm{HF}+22.4 \mathrm{H}_{2} \mathrm{O}\right)$

$\mathrm{UO}_{2} \mathrm{~F}_{2} \cdot \mathrm{nH}_{2} \mathrm{O}(\mathrm{c})$

Suponitskii et al (1971) report the following $\Delta \mathrm{H}^{\prime}$ s soln. in $571 \mathrm{H}_{2} \mathrm{O}$ :

$\begin{array}{ll} & \Delta \mathrm{H}, \mathrm{kcal} / \mathrm{mol} \\ \mathrm{UO}_{2} \mathrm{~F}_{2}(\mathrm{c}) & -7.12 \pm .11 \\ \mathrm{UO}_{2} \mathrm{~F}_{2} \cdot 1.6 \mathrm{H}_{2} \mathrm{O}(\mathrm{c}) & -2.05 \pm .07 \\ \mathrm{UO}_{2} \mathrm{~F}_{2} \cdot 3 \mathrm{H}_{2} \mathrm{O}(\mathrm{c}) & -1.46 \pm .06 \\ \mathrm{UO}_{2} \mathrm{~F}_{2} \cdot 4 \mathrm{H}_{2} \mathrm{O}(\mathrm{c}) & -1.35 \pm .02\end{array}$

Tsvetkov et al (1972) report from tensimetric measurements:

Reaction

$\Delta \mathrm{H}$

$\triangle G^{\circ} 298$

$\mathrm{kcal} / \mathrm{mol} \mathrm{H}_{2} \mathrm{O}(\mathrm{g})$

$\mathrm{kcal} / \mathrm{mol} \mathrm{H}_{2} \mathrm{O}(\mathrm{g})$

$12.8 \pm 0.8$

$12.6 \pm 0.8$

$10.7 \pm 1.2$

$13.3 \pm 1.4$

$11.7 \pm 1.9$

$13.3 \pm 2.2$

$11.3 \pm 2.4$

$2.32 \pm 0.08$

$2.54 \pm 0.07$

$2.54 \pm 0.08$

$3.25 \pm 0.10$

$3.25 \pm 0.12$

$3.93 \div 0.13$

$3.93=0.15$ 
for the following:

$$
\begin{aligned}
& \mathrm{UO}_{2} \mathrm{~F}_{2} \cdot 4 \mathrm{H}_{2} \mathrm{O}(\mathrm{c})=\mathrm{UO}_{2} \mathrm{~F}_{2} \cdot 3 \mathrm{H}_{2} \mathrm{O}(\mathrm{c})+\mathrm{H}_{2} \mathrm{O}(\mathrm{g}) \\
& \mathrm{UO}_{2} \mathrm{~F}_{2} \cdot 3 \mathrm{H}_{2} \mathrm{O}(\mathrm{c})=\mathrm{UO}_{2} \mathrm{~F}_{2} \cdot 2 \cdot 18 \mathrm{H}_{2} \mathrm{O}(\mathrm{c})+0.82 \mathrm{H}_{2} \mathrm{O}(\mathrm{g}) \\
& \mathrm{UO}_{2} \mathrm{~F}_{2} \cdot 2 \cdot 18 \mathrm{H}_{2} \mathrm{O}(\mathrm{c})=\mathrm{UO}_{2} \mathrm{~F}_{2} \cdot 1.75 \mathrm{H}_{2} \mathrm{O}(\mathrm{c})+0.43 \mathrm{H}_{2} \mathrm{O}(\mathrm{g}) \\
& \mathrm{UO}_{2} \mathrm{~F}_{2} \cdot 1.75 \mathrm{H}_{2} \mathrm{O}(\mathrm{c})=\mathrm{UO}_{2} \mathrm{~F}_{2} \cdot 1.18 \mathrm{H}_{2} \mathrm{O}(\mathrm{c})+0.57 \mathrm{H}_{2} \mathrm{O}(\mathrm{g}) \\
& \mathrm{UO}_{2} \mathrm{~F}_{2} \cdot 1.18 \mathrm{H}_{2} \mathrm{O}(\mathrm{c})=\mathrm{UO}_{2} \mathrm{~F}_{2} \cdot 0.85 \mathrm{H}_{2} \mathrm{O}(\mathrm{c})+0.33 \mathrm{H}_{2} \mathrm{O}(\mathrm{g}) \\
& \mathrm{UO}_{2} \mathrm{~F}_{2} \cdot 0.85 \mathrm{H}_{2} \mathrm{O}(\mathrm{c})=\mathrm{UO}_{2} \mathrm{~F}_{2} \cdot 0.25 \mathrm{H}_{2} \mathrm{O}(\mathrm{c})+0.60 \mathrm{H}_{2} \mathrm{O}(\mathrm{g}) \\
& \mathrm{UO}_{2} \mathrm{~F}_{2} \cdot 0.25 \mathrm{H}_{2} \mathrm{O}(\mathrm{c})=\mathrm{UO}_{2} \mathrm{~F}_{2}(\mathrm{c})+0.25 \mathrm{H}_{2} \mathrm{O}(\mathrm{g})
\end{aligned}
$$

Then for:

$$
\mathrm{UO}_{2} \mathrm{~F}_{2} \cdot \mathrm{nH}_{2} \mathrm{O}(\mathrm{c}) \rightarrow \mathrm{UO}_{2} \mathrm{~F}_{2}(\mathrm{c})+\mathrm{nH}_{2} \mathrm{O}(\mathrm{I})
$$

we obtain:

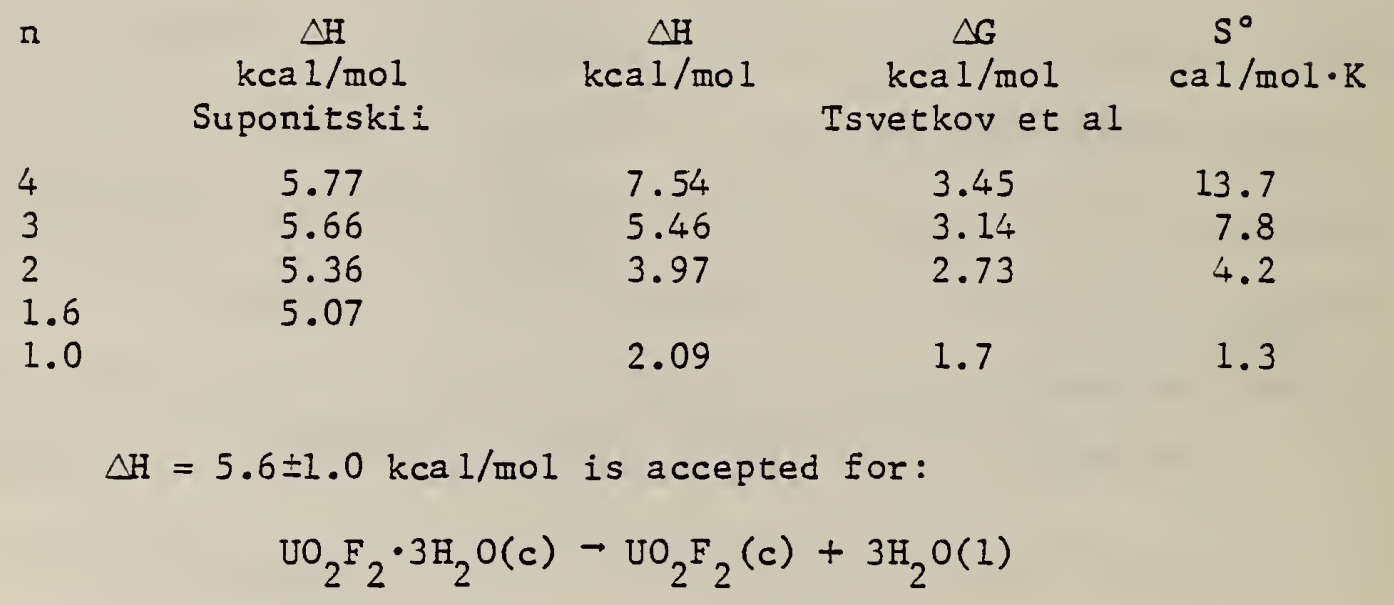

leading to $\Delta \mathrm{Hf}^{\circ} \mathrm{UO}_{2} \mathrm{~F}_{2} \cdot 3 \mathrm{H}_{2} \mathrm{O}(\mathrm{c})=-605.8 \pm 1.0 \mathrm{kcal} / \mathrm{mol}$. No values are given for the others because of the disagreement and the imprecise states of the hydrates. 
$\mathrm{UOF}(\mathrm{OH})(\mathrm{c})$ and $\mathrm{UOF}(\mathrm{OH}) \cdot 0.5 \mathrm{H}_{2} \mathrm{O}(\mathrm{c})$

Vdovenko et al. (1970a) prepared a black finely crystalline precipitate (by the addition of alkali to an aqueous solution containing $\mathrm{UF}^{3+}$ ) which has the composition $\mathrm{UOF}(\mathrm{OH}) \cdot 0.5 \mathrm{H}_{2} \mathrm{O}(\mathrm{c})$. They also measured the thermal properties at $293 \mathrm{~K}$, i.e. in 5N HCl (1970b).

$$
\begin{gathered}
\mathrm{UOF}(\mathrm{OH}) \cdot 0.5 \mathrm{H}_{2} \mathrm{O}(\mathrm{c})+254 \mathrm{HCl}(\mathrm{aq}) \\
-\left[\mathrm{UFCl}_{3}+251 \mathrm{HCl}+2.5 \mathrm{H}_{2} \mathrm{O}\right] \mathrm{aq} ; \\
\Delta \mathrm{H}_{1}=-13.84 \pm 0.15 \mathrm{kcal}
\end{gathered}
$$

and

$$
\begin{aligned}
{\left[\mathrm{UCl}_{4}+250 \mathrm{HCl}\right] \mathrm{aq}+\mathrm{HF}(\mathrm{aq})-\left[\mathrm{UFCl}_{3}+251 \mathrm{HCl}\right] \mathrm{aq} ; } \\
\Delta \mathrm{H}_{2}=-4.6 \pm 0.1 \mathrm{kca} 1 / \mathrm{mol}
\end{aligned}
$$

The concentrations appear to correspond, as in their similar solution measurements on $\mathrm{UOF}_{2} \cdot \mathrm{H}_{2} \mathrm{O}(\mathrm{c})$, to those used by Maltsev et al. (1960) in their determination of $\Delta \mathrm{HF}^{\circ} \mathrm{UF}_{4} \cdot 2.5 \mathrm{H}_{2} \mathrm{O}(\mathrm{c})$ and use is made of the Maltsev et al. reaction:

$$
\begin{aligned}
& \mathrm{UCl}_{4}(\mathrm{c})+250 \mathrm{HCl}(\mathrm{aq})-\left[\mathrm{UCl}_{4}+\right.250 \mathrm{HCl}] \mathrm{a}_{4} ; \\
& \Delta \mathrm{H}_{3}=-43.47 \pm 0.1 \mathrm{kcal}
\end{aligned}
$$

so that

$$
\begin{aligned}
\mathrm{UCl}_{4}(\mathrm{c})+\mathrm{HF}(40 \% \text { soln. })+2.5 \mathrm{H}_{2} \mathrm{O}(\mathrm{aq}) & - \\
\operatorname{UOF}(\mathrm{OH}) & \cdot 0.5 \mathrm{H}_{2} \mathrm{O}(\mathrm{c})+4 \mathrm{HCl}(\mathrm{a} \varphi) ; \\
\Delta \mathrm{H}_{4} & =-34.8 \pm 0.6{ }^{*} \mathrm{kcal} / \mathrm{mol}
\end{aligned}
$$

With the integral $\Delta \mathrm{Hf}^{\circ} \mathrm{HF}\left(40 \%\right.$ soln., $\left.\mathrm{HF}\left(1.667 \mathrm{H}_{2} \mathrm{O}\right)\right)=-76.42 \mathrm{kcal} / \mathrm{mol}$ and the differential $\triangle \overline{\mathrm{H} f}$ 's for $\mathrm{HCl}$ and $\mathrm{H}_{2} \mathrm{O}$ in a $5 \mathrm{~N} \mathrm{HCl}$ solution, i.e. $\mathrm{HCl}\left(10 \mathrm{H}_{2} \mathrm{O}\right) \Delta \mathrm{Hf}^{\circ}=-376.7 \pm 1.5 \mathrm{kcal} / \mathrm{mol}$ for the hemihydrate.

\footnotetext{
* Corrected to $298 \mathrm{~K}$, assuming $\Delta \mathrm{C}_{\mathrm{p}}=-120 \mathrm{cal} / \mathrm{mol} \cdot \mathrm{K}$.
} 
Vdovenko et al. (1970b) also measured the vapor pressure (283-363 K) and reported for:

$$
\begin{gathered}
\operatorname{UOF}(\mathrm{OH}) \cdot 0.5 \mathrm{H}_{2} \mathrm{O}(\mathrm{c}) \rightarrow \operatorname{UOF}(\mathrm{OH})(\mathrm{c})+0.5 \mathrm{H}_{2} \mathrm{O}(\mathrm{g}) ; \\
\Delta \mathrm{H}_{5}=10.4 \mathrm{kcal} / \mathrm{mol} \mathrm{H}_{2} \mathrm{O}(\mathrm{g}) \text { and } \Delta \mathrm{S}_{5}=25.6 \mathrm{cal} / \mathrm{mol} \mathrm{H}_{2} \mathrm{O}(\mathrm{g}) \cdot \mathrm{K}
\end{gathered}
$$

If one assumes (5) to be the process, one would expect $\Delta S$ to be 35-36 $\mathrm{ca} I / \mathrm{mol} \cdot \mathrm{K}$. If this $\Delta S$ is used and one assumes the $\Delta G^{\circ}$ is reasonable $\approx 2.8 \mathrm{kcal} / \mathrm{mol}$, a $\Delta H \approx 13.2 \mathrm{kcal} / \mathrm{mol} \mathrm{H}_{2} \mathrm{O}(\mathrm{g})$ is obtained, and $\Delta H \mathrm{f}^{\circ}$ $\mathrm{UOF}(\mathrm{OH})(\mathrm{c}) \approx-341 \pm 3.0 \mathrm{kcal} / \mathrm{mol}$. 
$\mathrm{UO}_{2}(\mathrm{OH}) \mathrm{F} \cdot \mathrm{H}_{2} \mathrm{O}(\mathrm{c})$ and $\mathrm{UO}_{2}(\mathrm{OH}) \mathrm{F} \cdot 2 \mathrm{H}_{2} \mathrm{O}(\mathrm{c})$

Tsvetkov et al. (1973) observed the existence, in the $\mathrm{UO}_{3}-\mathrm{HF}-\mathrm{H}_{2} \mathrm{O}$ system, of two hydrates of a basic salt of variable composition; they are $\mathrm{UO}_{2}(\mathrm{OH})_{x}{ }_{2-x} \cdot 2 \mathrm{H}_{2} \mathrm{O}$ and $\mathrm{UO}_{2}(\mathrm{OH})_{x}{ }_{2-x} \cdot \mathrm{H}_{2} \mathrm{O}$, where $\mathrm{x}=0.3-1.2$. The thermodynamic characteristics have been determined by DTA.

They report the following for the case when $x=1$.

$$
\begin{aligned}
& \mathrm{UO}_{2}(\mathrm{OH}) \mathrm{F} \cdot \mathrm{H}_{2} \mathrm{O}(\mathrm{c})-1 / 2 \mathrm{UC}_{2} \mathrm{~F}_{2}(\mathrm{c})+1 / 2 \mathrm{LO}_{3} \cdot \mathrm{H}_{2} \mathrm{O}(\mathrm{c})+\mathrm{H}_{2} \mathrm{O}(\mathrm{g}) \\
& \log \mathrm{P}(\mathrm{atm})=(7.60 \pm 0.84)-(3100 \pm 246) / \mathrm{T}(303-408 \mathrm{~K}) \\
& \mathrm{UO}_{2}(\mathrm{OH}) \mathrm{F} \cdot 2 \mathrm{H}_{2} \mathrm{O}(\mathrm{c})-\mathrm{UO}_{2}(\mathrm{OH}) \mathrm{F} \cdot \mathrm{H}_{2} \mathrm{O}(\mathrm{c})+\mathrm{H}_{2} \mathrm{O}(\mathrm{g}) \\
& \log \mathrm{P}(\mathrm{atm})=(6.23 \pm 0.52)-(2360 \pm 141) / \mathrm{T}(303-379 \mathrm{~K})
\end{aligned}
$$

The calculated values at $298 \mathrm{~K}$ are:

For reaction (1) $\Delta \mathrm{H}_{1}=14.2 \mathrm{kcal} / \mathrm{mol} \mathrm{H}_{2} \mathrm{O}(\mathrm{g})$

$$
\begin{aligned}
\Delta G^{\circ}{ }_{1} & =3.82 \mathrm{kcal} / \mathrm{mol} \mathrm{H}_{2} \mathrm{O}(\mathrm{g}) \\
\Delta S^{\circ}{ }_{1} & =34.8 \mathrm{cal} / \mathrm{mol} \mathrm{H}{ }_{2} \mathrm{O}(\mathrm{g})
\end{aligned}
$$

for reaction (2) $\Delta \mathrm{H}_{2}=10.8 \mathrm{kcal} / \mathrm{mol} \mathrm{H}_{2} \mathrm{O}(\mathrm{g})$

$$
\begin{aligned}
\Delta G^{\circ}{ }_{2} & =2.3 \mathrm{kcal} / \mathrm{mol} \mathrm{H} \mathrm{H}_{2} \mathrm{O}(\mathrm{g}) \\
\Delta \mathrm{S}^{\circ}{ }_{2} & =28.5 \mathrm{cal} / \mathrm{mol} \mathrm{H} \mathrm{H}_{2} \mathrm{O}(\mathrm{g})
\end{aligned}
$$

The formation properties of $\mathrm{UO}_{2}(\mathrm{OH}) \mathrm{F} \cdot \mathrm{H}_{2} \mathrm{O}(\mathrm{c})$ are obtained from the values for reaction (1) since the formation properties of $\mathrm{UO}_{2} \mathrm{~F}_{2}(\mathrm{c})$ and $\mathrm{UO}_{3} \cdot \mathrm{H}_{2} \mathrm{O}(\mathrm{c}) *$ are known.

For reaction (2), the $\Delta H$ and $\Delta S^{\circ}$ are unreasonable. The normal $\Delta S^{\circ}{ }_{\text {dehyd }} \approx 35-36 \mathrm{cal} / \mathrm{mol} \mathrm{H}_{2} \mathrm{O}(\mathrm{g})$. A more reasonable $\Delta \mathrm{H}=13.0$ $\mathrm{kcal} / \mathrm{mol}$ results from using the measured $\Delta G_{2}^{\circ}=1.11 \mathrm{kcal} / \mathrm{mol}$ at $\mathrm{T}=340 \mathrm{~K}$ and the estimated $\Delta S^{\circ}=35 \mathrm{cal} / \mathrm{mol}$.

$\triangle \mathrm{HF}^{\circ} \mathrm{UO} \cdot 3 \cdot \mathrm{H}_{2} \mathrm{O}(\mathrm{c}, 9)=-366.5 \pm 0.2 \mathrm{kcal} / \mathrm{mol}$ from Cordfunke and $\mathrm{O}^{\prime}$ Hare (1978) is used. Parker (1976) recommends $-366.6 \pm 0.3 \mathrm{kcal} / \mathrm{mol}$. 
Then for the dehydration

$$
\begin{aligned}
& \mathrm{UO}_{2}(\mathrm{OH}) \mathrm{F} \cdot 2 \mathrm{H}_{2} \mathrm{O}(\mathrm{c}) \rightarrow \mathrm{UO}_{2}(\mathrm{OH}) \mathrm{F} \cdot \mathrm{H}_{2} \mathrm{O}(\mathrm{c})+\mathrm{H}_{2} \mathrm{O}(\mathrm{g}) \\
& \Delta G^{\circ}=13,000-35 \mathrm{~T}(\mathrm{cal} / \mathrm{mol}) \quad(298-380 \mathrm{~K})
\end{aligned}
$$

and

$$
\log P(a t m)=7.65-2,840 / \mathrm{r} \text {. }
$$




\subsection{U-C1 Compounds}

$\underline{\mathrm{UC}} 1_{3}(\mathrm{c})$

The $298 \mathrm{~K}$ values for $\mathrm{S}^{\circ}$ and $\mathrm{H}-\mathrm{H}_{0}$ are taken from Katz and Rabinowitch's (1951) tabulation of the smoothed thermal functions obtained from the low temperature specific heat measurements of Ferguson and Prather (1944) (15-380 K) made on samples of unknown purity. They are considered accurate to $0.5 \%$. The measurements extrapolated to $0 \mathrm{~K}$ assuming no abnormal behavior results in $\mathrm{S}^{\circ}=$ $38.0 \mathrm{cal} / \mathrm{mol} \cdot \mathrm{K}$; however, as pointed out by MacWood (1958), the $\mathrm{UCl}_{3}$ curve appears unusual between $15-20 \mathrm{~K}$, appearing to approach a minimum at $\sim 10 \mathrm{~K}$. If this is so, then a better value for $\mathrm{S}^{\circ} \mathrm{UCl}_{3}$ (c) would be between 38.0 and $40.75 \mathrm{cal} / \mathrm{mol} \cdot \mathrm{K}$ where $\mathrm{R} \ln 4=2.75$ is the total magnetic entropy present in $\mathrm{UCl}_{3}(\mathrm{c})$. However, until more definitive measurements are made, $S^{\circ}=38.0 \pm 0.3 \mathrm{ca} i / \mathrm{mol} \cdot \mathrm{K}$ is accepted.

Ginnings and Corruccini (1947) measured the heat content relative to $273 \mathrm{~K}$ in the range $273-998 \mathrm{~K}$ using a higher purity sample ( $99.8 \%$ ) than Ferguson and Prather. In the overlapping range, 273-373 K, the derived $C_{p}$ 's are $0.5 \%$ lower.

Kelley (1960) tabulated the $\mathrm{C}_{\mathrm{P}}{ }^{\circ},\left(\mathrm{S}-\mathrm{S}_{298}\right)_{\mathrm{T}}$ and $\left(\mathrm{H}-\mathrm{H}_{298}\right)_{\mathrm{T}}$ from the Ginnings and Corruccini results which, with the low temperature $\mathrm{S}^{\circ}$, results in the thermal functions to $1000 \mathrm{~K}$. The results can be expressed as:

$$
\begin{aligned}
\mathrm{H}_{\mathrm{T}}-\mathrm{H}_{298 \mathrm{~K}}=20.98 \mathrm{~T}+ & 3.72 \times 10^{-3} \mathrm{~T}^{2}-1.16 \times 10^{5} \mathrm{~T}^{-1}-6,197 \mathrm{cal} / \mathrm{mol} \\
& (298-1,000 \mathrm{~K})
\end{aligned}
$$




$$
\begin{aligned}
& \text { Fontana }(1947) \text { and }(1958) \text { measured the following: } \\
& \begin{aligned}
\mathrm{UCl}_{3}(\mathrm{c})+\left[1 / 2 \mathrm{UO}_{2}^{2+}+2 \mathrm{H}^{+}\right] \text {in } 0.5 \mathrm{~m} \mathrm{HClO} \\
\\
{\left[3 / 2 \mathrm{U}^{4+}+3 \mathrm{Cl}^{-}+\mathrm{H}_{2} \text { o] in } 0.5 \mathrm{~m} \mathrm{HClO} ; \Delta \mathrm{H}_{1}=-69.07 \pm 0.5 \mathrm{kcal} / \mathrm{mol}\right.}
\end{aligned}
\end{aligned}
$$

With the values for the $\Delta H f^{\prime}$ 's for $U^{4+}\left(0.5 \mathrm{~m} \mathrm{HClO} O_{4}\right)$ and $\mathrm{UO}_{2}{ }^{2+}$ (0.5m $\mathrm{HClO}_{4}$ ) from Fuger and Detting (1976) and the assumption that the enthalpy of formation of the $\mathrm{Cl}^{-}$in $0.5 \mathrm{~m} \mathrm{HClO}_{4}$ is the same as in $0.5 \mathrm{~m}$ $\mathrm{HCl}, \Delta \mathrm{Hf}^{\circ} \mathrm{UCl}_{3}(\mathrm{c})=-207.3 \pm 1.3 \mathrm{kcal} / \mathrm{mol}$ is calculated.

However, since Fontana made a whole series of calorimetric oxidation reduction measurements on $\mathrm{UCl}_{3}(c), \mathrm{UCl}_{4}(c)$, and $\mathrm{U}^{4+} \rightarrow \mathrm{UO}_{2}{ }^{2+}$ (see Fuger and Detting (1976)), another way of treating the above measurements would be to rearrange his reactions and obtain the $\triangle \mathrm{H}_{\text {soln }} \cdot \mathrm{UCl}_{3}(\mathrm{c})$ :

$$
\mathrm{UCl}_{3}(\mathrm{c}) \rightarrow\left[\mathrm{U}^{3+}+3 \mathrm{Cl}^{-}\right] \text {in } 0.5 \mathrm{~m} \mathrm{HClO} \mathrm{m}_{4} ; \Delta \mathrm{H}_{2}=-28.97 \pm 0.5 \mathrm{kcal} / \mathrm{mol}
$$

Assuming $\triangle H f^{\circ} U^{3+}$ (in $\left.0.5 m \mathrm{HClO}_{4}\right) \approx \Delta \mathrm{Hf}^{\circ} \mathrm{U}^{3+}($ aq, std. state), one obtains $\Delta \mathrm{HF}^{\circ} \mathrm{UCl}_{3}(\mathrm{c})=-206.5 \pm 1.3 \mathrm{kcal} / \mathrm{mol}$.

Another approach, which minimizes the assumptions regarding the value to be used for the formation of $\mathrm{Cl}^{-}$in $0.5 \mathrm{~m} \mathrm{HClO}_{4}$ and ties $\Delta \mathrm{Hf}^{\circ} \mathrm{UCl}_{3}(\mathrm{c})$ to $\Delta \mathrm{Hf}^{\circ} \mathrm{UCl}_{4}$ (c) is through the rearrangement of Fontana 's' reactions to:

$$
\begin{aligned}
\mathrm{UCl}_{3}(\mathrm{c})+\mathrm{HCl}\left(\text { in } 0.5 \mathrm{~m} \mathrm{HClO}_{4}\right) \rightarrow \mathrm{UCl}_{4}(\mathrm{c}) & +1 / 2 \mathrm{H}_{2}(\mathrm{~g}) ; \\
\Delta \mathrm{H}_{3} & =+3.01 \pm 0.6 \mathrm{kcal} / \mathrm{mol}
\end{aligned}
$$

Although, again the partial $\triangle \bar{H} f$ of $\mathrm{HCl}$ is to be used, the solution now involves only one mole of $\mathrm{HCl}$, an introduction of only $\sim 0.1 \mathrm{kcal}$ uncertainty. The resultant $\Delta \mathrm{Hf}^{\circ} \mathrm{UCl}_{3}(\mathrm{c})=-207.0 \pm 0.9 \mathrm{kcal} / \mathrm{mol}$. 
The experimental calorimetric results of Barkelerw given by MacWood (1958) result in:

$$
\mathrm{UCl}_{3}(\mathrm{c})+\mathrm{Cl}_{2}(\mathrm{~g})-\mathrm{UCl}_{4}(\mathrm{c}) ; \Delta \mathrm{H}_{4}=-38.1 \mathrm{kcal} / \mathrm{mol}
$$

and $\Delta \mathrm{Hf}^{\circ} \mathrm{UCl}_{3}(\mathrm{c})=-205.4=2.0 \mathrm{kcal} / \mathrm{mol}$.

MacWood (1958) also tabulates the $\mathrm{X}$ 's from Altman (1944) and Gregory (1945) for the $\mathrm{UCl}_{4}$ hydrogen reduction equilibrium (673 to $823 \mathrm{~K})$. The third law $\Delta \mathrm{H}^{\circ}$ values for the reaction:

$$
\mathrm{UCl}_{4}(\mathrm{c})+1 / 2 \mathrm{H}_{2}(\mathrm{~g})-\mathrm{UCl}_{3}(\mathrm{c})+\mathrm{HCl}(\mathrm{g})
$$

are :

$$
\begin{array}{ll}
\text { Altman } & \Delta \mathrm{H}^{\circ}{ }_{5}=14.36 \pm 0.1 \mathrm{kcal} / \mathrm{mol} \mathrm{UCl}_{4}(\mathrm{c}) \\
\text { Gregory } & \Delta \mathrm{H}^{\circ}{ }_{5}=14.38 \pm 0.3 \mathrm{kcal} / \mathrm{mol} \mathrm{UCl}_{4} \text { (c) }
\end{array}
$$

The value obtained for $\Delta \mathrm{HF}^{\circ} \mathrm{UCl}_{3}(\mathrm{c})$ from the data of Altman and Gregory is $-207.0=0.7$ in excellent agreement with the calorimetric value from Fontana's results. However, as Maciood (1958) points out, if a value for $S^{\circ}=40.5 \mathrm{cal} / \mathrm{mol} \cdot \mathrm{K}$ is used for $\mathrm{UCl}_{3}(\mathrm{c})$, then the 3rd law $\Delta \mathrm{H}^{\circ}=16.21 \mathrm{kcal} / \mathrm{mol}$ and $\Delta \mathrm{Hf}^{\circ} \mathrm{UCl}_{3}$ (c) from Altman and Gregory is $-205.2 \mathrm{kcal} / \mathrm{mol}$ in better agreement with the calorimetric value of -205.4 from Barkelew and Maciood. At present, the value $-207.0 \pm 1.0$ is accepted.

A value of $-29.5 \pm 0.6 \mathrm{kcal} / \mathrm{mol}$ (Fuger (1976)) for $\Delta \mathrm{H}^{\circ}$ soln $\mathrm{UCl}_{3}(\mathrm{c})$ at infinite dilution can be estimated from the experimental $\Delta \mathrm{H}_{\text {solr. }} \mathrm{PuCl}_{3}$ (c) and $\mathrm{AmCl}_{3}(\mathrm{c})$. This value with the $\Delta \mathrm{Hf}^{\circ} \mathrm{U}^{3+}$ (aq, std. State) results in $\mathrm{AHF}^{\circ} \mathrm{UCl}_{3}(\mathrm{c})=-207.2 \pm 1.1$ in support of $-207.0=1.0 \mathrm{kcal} / \mathrm{mol}$. 
There are other measurements pertaining to $\mathrm{UCl}_{3}(\mathrm{c})$.

Hardy-Grens (1964) reported pressure measurements for the decomposition of $\mathrm{UCl}_{3}(\mathrm{c})$. The assumed reaction is:

$$
4 / 3 \mathrm{UCl}_{3}(\mathrm{c}) \rightarrow \mathrm{UCl}_{4}(g)+1 / 3 \mathrm{U}(\mathrm{c})
$$

The reported $\Delta G^{\circ}(1030$ to $1173 \mathrm{~K})$ is $52,900-27.9 \mathrm{~T} \mathrm{cal} / \mathrm{mol} \mathrm{UCl}_{4}(\mathrm{~g})$ with $\Delta H_{298}^{\circ}=57.7 \mathrm{kcal} / \mathrm{mol}$ (assuming $\Delta \mathrm{C}_{\mathrm{p}}=-6 \mathrm{cal} / \mathrm{mol} \cdot \mathrm{K}$ ) and $\Delta \mathrm{S}^{\circ}{ }_{298}=35.8$ $\mathrm{cal} / \mathrm{mol} \cdot \mathrm{K}$, resulting in $-188.3 \mathrm{kcal} / \mathrm{mol}$ for $\Delta \mathrm{Hf}^{\circ} \mathrm{UCl}_{3}(\mathrm{c})$ and $\mathrm{S}^{\circ} \mathrm{UCl}_{3}(\mathrm{c})$ $=51 \mathrm{cal} / \mathrm{mol} \cdot \mathrm{K}$.

Similarly Shchukarev et al. (1956) reported, in the temperature range 863 to $1063 \mathrm{~K}$ :

$$
\Delta G=51,000-27.5 \mathrm{~T} \mathrm{cal} / \mathrm{mol}
$$

This results in $\Delta \mathrm{H}_{298}=55.0 \mathrm{kcal} / \mathrm{mol} \mathrm{UCl}_{4}(\mathrm{~g})$ and $\Delta \mathrm{Hf}^{\circ}=-186.3$ $\mathrm{kcal} / \mathrm{mol}$ for $\mathrm{UCl}_{3}(\mathrm{c})$.

These two sets of measurements are in reasonable agreement with one another but differ with both the calorimetric values and the $\mathrm{UCl}_{4}-\mathrm{H}_{2}$ reduction equilibria values. It may be that the measurements made do not pertain to the disproportionation process. The tabulated $\Delta G f^{\circ}$ is obtained from the accepted $\Delta H f^{\circ}$ and $\Delta S f^{\circ}$. 
$\mathrm{UCl}_{4}(\mathrm{c})$

The low temperature heat capacities (15-355 K) have been measured by Ferguson et a1. (1944a). The $\mathrm{C}_{\mathrm{p}}{ }^{0},\left(\mathrm{H}-\mathrm{H}_{0}\right) \mathrm{T}$ and $\mathrm{S}^{\circ}$ at $298 \mathrm{~K}$ are taken from Katz and Rabinowitch's (1951) tabulated values. It is appropriate at this point to point out that the $S^{\circ} \mathrm{UC}_{4}$ at $298.15 \mathrm{~K}\left(47.1_{4}\right)$ has been listed in various places as $47.4 \mathrm{cal} / \mathrm{mol} \cdot \mathrm{K}$ [for example Rand and Kubaschewski (1963) and Rossini et al. (1952)]. There is no evidence that a reevaluation of the low temperature $C_{p}$ and $S^{\circ}$ was made. It would appear to be an error in transcriptiun.

Ginnings and Corruccini (1947) measured the heat content of $\mathrm{UCl}_{4}(\mathrm{c})$ in the range $700 \mathrm{~K}$ to $273 \mathrm{~K}$. Popov et al. (1959a) measured the $C_{p}$ from $450 \mathrm{~K}$ to $920 \mathrm{~K}$ (above the melting point). A reasonable presentation of the high temperature measurements has been made by Rand and Kubaschewski (1963):

$$
\begin{aligned}
\mathrm{UCl}_{4}(\mathrm{c}) \quad \mathrm{C}_{\mathrm{P}}= & 27.2+8.57 \times 10^{-3} \mathrm{~T}-0.79 \times 10^{5} \mathrm{~T}^{-2} \mathrm{cal} / \mathrm{mol} \cdot \mathrm{K} \\
& (400-800 \mathrm{~K}) \\
\mathrm{UCl}_{4}(1) \quad \mathrm{C}_{\mathrm{p}}= & 25.8+14.4 \times 10^{-3} \mathrm{~T} \quad \mathrm{cal} / \mathrm{mol} \cdot \mathrm{K} \\
& (890-920 \mathrm{~K})
\end{aligned}
$$

In combination with the vapor pressure measurements (see $\mathrm{UCl}_{4}(g)$ ) the following is accepted:

at the melting point, $863 \mathrm{~K}$ (Meller (1948)):

$$
\begin{aligned}
& \mathrm{UCl}_{4}(\mathrm{c})-\mathrm{UCl}_{4}(\mathrm{l}) \\
& \Delta \mathrm{H}=10.9 \mathrm{kcal} / \mathrm{mol} \\
& \Delta \mathrm{S}=12.6 \mathrm{cal} / \mathrm{mol} \cdot \mathrm{K}
\end{aligned}
$$

$\mathrm{UCl}_{4}(c)$ is a key compound in the evaluation of a consistent set of thermodynamic data for the uranium compounds, and until 1971 the 
$\Delta \mathrm{Hf}^{\circ}$ had been considered to be firmly established as $-251 \mathrm{kcal} / \mathrm{mol}$. [See Rand and Kubaschewski (1963), Rossini et al. (1952), Brewer et al. (1945)]. However, an inconsistency noted by Rand and Kubaschewski existed in the paths to $\Delta \mathrm{Hf}^{\circ} \mathrm{HO}_{2}{ }^{2+}$ (aq, std. state) and the various forms of $\mathrm{UO}_{3}(c)$. These inconsistencies can now be traced primarily to the $\triangle \mathrm{Hf}^{\circ}$ 's of $\mathrm{UCl}_{4}(\mathrm{c})$ and $\mathrm{UO}_{2} \mathrm{Cl}_{2}(\mathrm{c})$.

These early measurements and subsequent ones in support of the above mentioned value for $\Delta \mathrm{Hf}^{\circ}$ have been recalculated and are listed below. They are given no further consideration for the selection of $\Delta H f^{\circ}$ $\mathrm{UC}_{4}(\mathrm{c})$.

These values ${ }^{*}$ were obtained from measurements of $U(c)$ and $\mathrm{UCl}_{4}(\mathrm{c})$ in excess $\mathrm{HCl}$ so that:

$$
\begin{aligned}
& \mathrm{U}(\mathrm{c})+4 \mathrm{HCl}(\mathrm{aq}) \rightarrow \mathrm{UCl}_{4}(\mathrm{aq} ; \text { in excess } \mathrm{HCl})+2 \mathrm{H}_{2}(\mathrm{~g}) ; \Delta \mathrm{H}_{1} \\
& \mathrm{UCl}_{4}(\mathrm{c}) \rightarrow \mathrm{UCl}_{4}(\mathrm{aq} \text {, in } \mathrm{HCl}) ; \Delta \mathrm{H}_{2}
\end{aligned}
$$

and by difference:

$$
\begin{aligned}
& \mathrm{U}(\mathrm{c})+4 \mathrm{HCl}(\mathrm{aq}) \rightarrow \mathrm{UCl}_{4}(\mathrm{c})+2 \mathrm{H}_{2}(\mathrm{~g}) ; \Delta \mathrm{H}_{3} \\
& \Delta \mathrm{H}_{3}=\Delta \mathrm{H}_{1}-\Delta \mathrm{H}_{2}=\Delta \mathrm{Hf}^{\circ} \mathrm{UCl}_{4}(\mathrm{c})-4 \Delta \mathrm{Hf} \mathrm{HCl}(\mathrm{aq})
\end{aligned}
$$

The measurements of Barkelew were for oxidation in $\mathrm{HCl}-\mathrm{FeCl}_{3}$ soln., but by difference $\Delta \mathrm{H}_{3}$ is for the same reaction. 
Inves tigat or

Smith et a l. (1969)

Argue et a1. (1961)

Barkelew [MacWood (1946)]

Biltz anc' Fendius (1928)
$T K$ of measurement

298

298

273

273
Conc. HCl,

$\mathrm{HCl} \cdot \mathrm{nH}_{2} \mathrm{O}$

8.13

8.13

$\star$

8 .
$\Delta \mathrm{HF}^{\circ} \mathrm{UCl}_{4}$ (c) $\mathrm{kca} 1 / \mathrm{mol}$

$-251.0$

$-250.5 \pm 0.6$

$-249.8^{*}$

$-248.2^{* \star}$

Fitzgibbon et a1. (1971) redetermined the $\angle \mathrm{Hf}^{\circ} \mathrm{UCl}_{4}$ (c) by two independent paths, and obtained significantly different results from those tabulated above. Their measurements were confirmed by Cordfunke et al. (1976); the resultant newly established $\Delta \mathrm{Hf}^{\circ} \mathrm{UCl}_{4}(\mathrm{c})=$ $-243.5 \pm 0.6 \mathrm{kcal} / \mathrm{mol}$ has resolved many of the earlier inconsistencies in the uranium network of key values. Measurements by Fitzgibbon et al. also offer a reasonable explanation for the more negative values arrived at earlier.

One of Fitzgibbon's paths is a repeat of the above; i.e., reactions (1) and (2) for which $\Delta \mathrm{H}_{1}=-137.5 \pm 0.5 \mathrm{kcal} / \mathrm{mol}$ when $\mathrm{m}_{\mathrm{HCl}}=4.35$, or $\mathrm{HCl}\left(12.76 \mathrm{H}_{2} 0\right)$ and $\Delta \mathrm{H}_{1}=-136.2 \pm 1.0 \mathrm{kcal} / \mathrm{mol}$ when $\mathrm{m}_{\mathrm{HCl}}=6.83$, or $\left.\mathrm{HCl}: 8.13 \mathrm{H}_{2} \mathrm{O}\right)$, and $\Delta \mathrm{H}_{2}=-45.7 \pm 0.5$ and $-39.3 \pm 0.5 \mathrm{kcal} / \mathrm{mol}$, respectively.

Using the differentials $\Delta \overline{\mathrm{H}} \mathrm{HCl}\left(12.76 \mathrm{H}_{2} \mathrm{O}\right)=-37.856 \mathrm{kcal} / \mathrm{mol}$ and $\Delta \overline{\mathrm{H}} \mathrm{HCl}\left(8.13 \mathrm{H}_{2} 0\right)=-36.671 \mathrm{kcal} / \mathrm{mol}$, values of $-243.22 \pm 0.70$ and $-243.58 \pm 1.1 \mathrm{kcal} / \mathrm{mol}$ are obtained for $\Delta \mathrm{Hf}^{\circ} \mathrm{UCl}_{4}(\mathrm{c})$.

Barkelew used a $12 \mathrm{M} \mathrm{HCl}-\mathrm{FeCl}_{3}$ solution and experimentally determined the $\Delta \bar{H}$ HCl in this medium at $273 \mathrm{~K}$ as $-33.0 \mathrm{kcal} / \mathrm{mol}$; certain auxiliary components needed revising so that $\triangle \bar{H} f \mathrm{HC} l$ for use in the Barkelew $\mathrm{HCl}-\mathrm{FeCl}_{3}$ medium is $-32.7 \mathrm{kcal} / \mathrm{mol}$.

Earlier evaluations had $\Delta \mathrm{Hf}^{\circ}=-251$, in exact agreement with Barke lew (MacWood); an erroneous interpretation of $\Delta \mathrm{Hf}^{\circ} \mathrm{HCl}$ and the experimental $\triangle H \operatorname{mix}$ had been made. 
The $\Delta H^{\prime}$ 's for the individual reactions, particularly (1), are significantly less negative than the earlier measurements. It would appear, as explained by Fitzgibbon et al., that the earlier measurements for the reaction of $U(c)$ with $\mathrm{HCl}(\mathrm{aq})$ were not for process (1). Probably not all dissolved oxygen had been eliminated; nor had a scavenger been used $\left(\mathrm{SiF}_{2}{ }^{2-}\right.$ in the acid) to prevent the formation of insoluble residues from the reaction of $U(c)$ in $\mathrm{HCl}$ solutions.

The other path, which confirms the above values is dependent upon $\mathrm{UO}_{2}(\mathrm{c})$. Fitzgibbon's experimental measurements, and those of Cordfunke et al. (1976) who repeated the measurements are cited in the following Table 6 . 


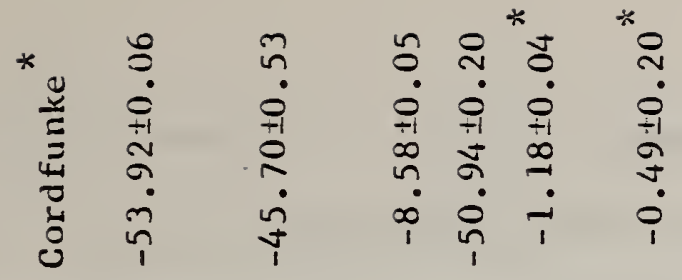

$$
\begin{aligned}
& \stackrel{\ddot{0}}{\dot{0}}
\end{aligned}
$$

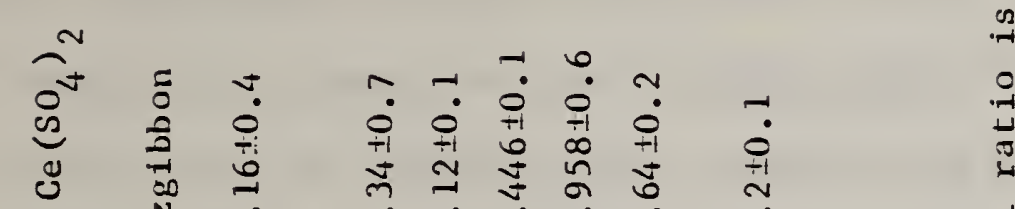

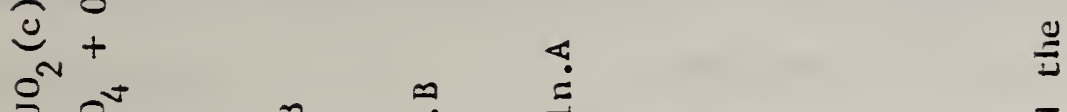

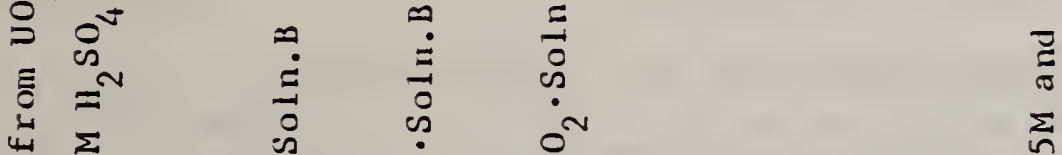

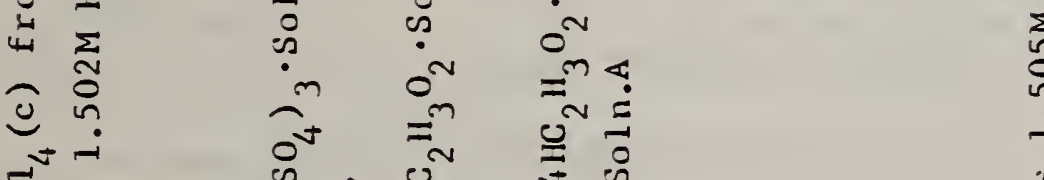

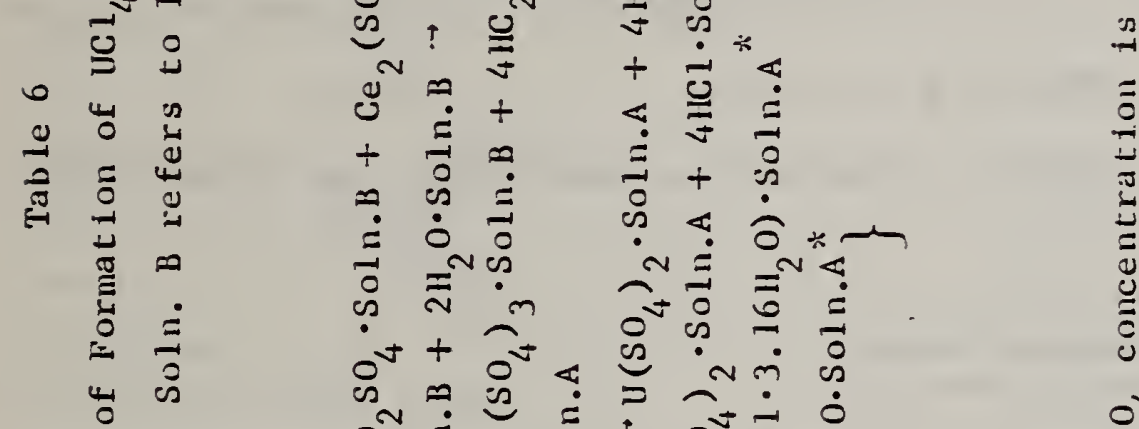

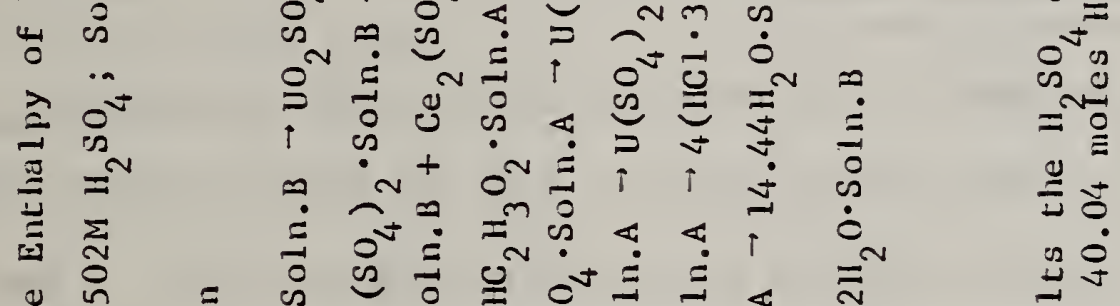

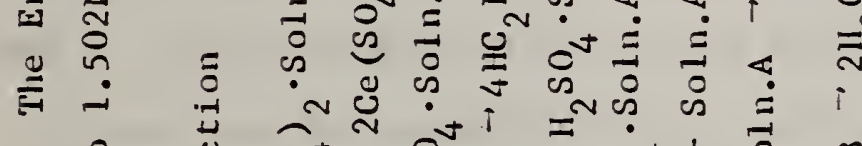

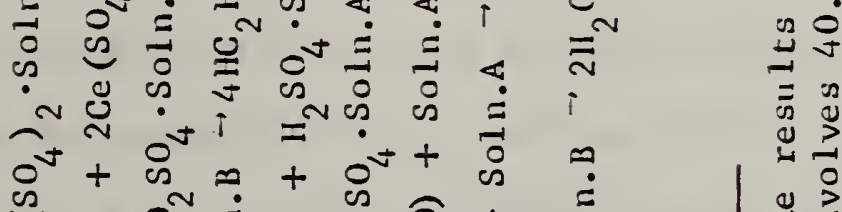

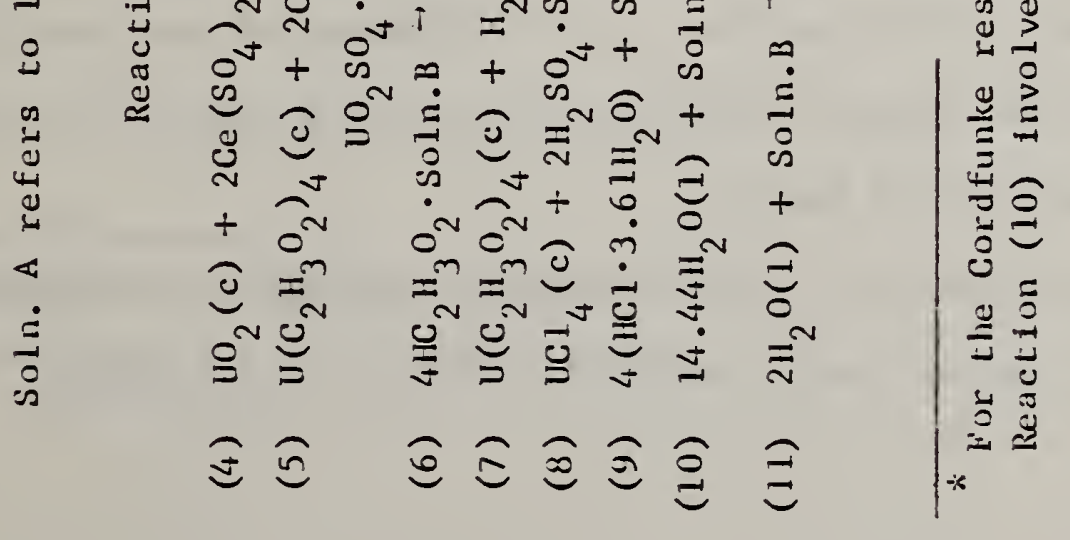


The summation results in:

$$
\mathrm{UO}_{2}(\mathrm{c})+4 \mathrm{HCl}(\mathrm{aq})-\mathrm{UCl}_{4}(\mathrm{c})+2 \mathrm{H}_{2} \mathrm{O}(\mathrm{l}) ; \Delta \mathrm{H}_{12}
$$

and $\Delta \mathrm{H}_{12}=23.37 \pm 0.9$ and $33.55 \pm 0.60 \mathrm{kcal} / \mathrm{mol}$, respectively. With $\Delta \mathrm{Hf}^{\circ} \mathrm{UO}_{2}(\mathrm{c})=-259.3 \pm 0.2$ based on the combustion work of Huber and Holley (1969) and the integral values for $\Delta H f^{\circ} \mathrm{HCl}(\mathrm{aq}), \Delta \mathrm{Hf}^{\circ}=$ $-243.95 \pm 1.1$ (Fitzgibbon) and $-243.27 \pm 0.65 \mathrm{kcal} / \mathrm{mol}$ (Cordfunke).

A weighted average from these four values results in the selected $\Delta \mathrm{HF}^{\circ} \mathrm{UCl}_{4}(\mathrm{c})=-243.5 \pm 0.6 \mathrm{kcal} / \mathrm{mol}$.

These two paths to $\mathrm{Hff}^{\circ} \mathrm{UCl}_{4}(\mathrm{c})$, one independent of other uranium compounds and one dependent upon $\Delta \mathrm{Hf}^{\circ} \mathrm{UO}_{2}(\mathrm{c})$, are mutually consistent; i.e., the $\Delta \mathrm{Hf}^{\circ} \mathrm{UCl}_{4}(c)$, independent of other uranium compounds supports a $\Delta \mathrm{Hf}^{\circ} \mathrm{UO}_{2}(\mathrm{c})=-259.3 \pm 0.2 \mathrm{kcal} / \mathrm{mol}$.

The Gibbs energy of formation has been calculated from the $\Delta \mathrm{Hf}^{\circ}$ and $\Delta S f^{\circ}$. $\mathrm{UCl}_{4}$ in Various Aqueous Media

The concern here is with the bulk $\Delta H_{\text {soln }}$, that is, the $\Delta H_{\text {soln }}$ of $\mathrm{UCl}_{4}(c)$ in various aqueous media to form the real solution, which in HCl may be highly complexed and in dilute $\mathrm{HCl}$ and $\mathrm{HClO}_{4}$, a partly hydrolyzed one, correcting only for the presence of the foreign silicate ion when present, temperature (if not at $298.15 \mathrm{~K}$ ) and possible impurities if known.

In all measurements cited here the concentration of the $\mathrm{UCl}_{4}$ in solution is below $.01 \mathrm{~m}$. There is at present insufficient 
experimental information to correlate the $\Delta \mathrm{H}_{\mathrm{Soln}} \mathrm{UCl}_{4}$ as a function of $\mathrm{m}_{\mathrm{UCl}_{4}}$.

1. Measurements in $\mathrm{HCl}$

In Fuger and Detting (1976) the measurements were corrected and extrapolated from $\mathrm{HCl}$ and $\mathrm{HClO}_{4}$ solutions in order to obtain the $\Delta H f^{\circ}, \Delta G f^{\circ}$, and $S^{\circ}$ for $U^{4+}$ (aq, std. state). For convenience they are repeated here (uncorrected for hydrolysis) along with additional measurements .

\section{Investigator}

Biltz and Fendius (1928)

Kilner (see Brewer et al. (1958))

Smith et al. (1969)

Fitzgibbon et al. (1971)

Argue et al. (1961)

Maltsev et a1. (1960)

Fitzgibbon et a1. (1971)

Hearne and White (1957)

Fuger and Brown (1970)

Argue et a 1. (1961)
Conc. $\mathrm{m}$, moles $\mathrm{HCl} / \mathrm{kg} \mathrm{H}_{2} \mathrm{O} \quad \Delta \mathrm{H}_{\mathrm{soln}} \mathrm{kcal} / \mathrm{mol}$

7.2

7.2

6.90

6.82

6.82

5.53

4.35

2.08

1.02

1.02
$-39.4^{*}$

$-36.2$

$-40.0$

$-38.9$

$-42.7$

$-43.47^{x+1}$

$-45.3$

$-51.53$

$-54.46$

$-57.0$

\footnotetext{
Measurements at $273 \mathrm{~K}$, uncorrected.

** Measurements at $293 \mathrm{~K}$, uncorrected.
} 
2. Measurements in $\mathrm{HClO}_{4}$

Inves tigator

Argue et al. (1961)**

Fontana (1947)

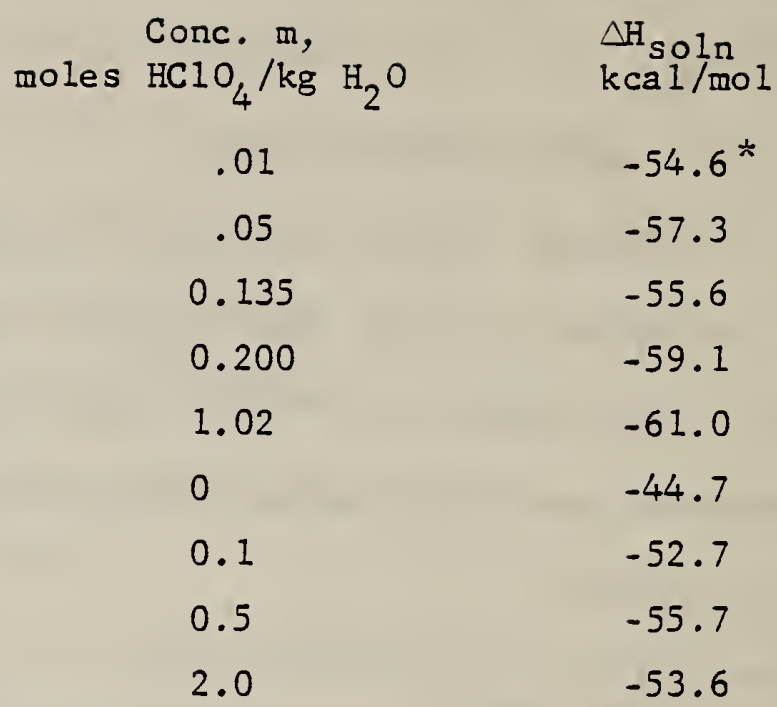

3. Measurements in Acid-Salt Mixtures

Investigator

$$
\begin{aligned}
& \text { Fontana (1947) } \\
& \text { [ concentration } \mathrm{UCl}_{4} \sim 5 \times 10^{-3} \mathrm{~m} \text { ] } \\
& \text { Hearne and White }(1957) \\
& \text { [ concentration } \mathrm{UCl}_{4} \sim 5 \times 10^{-4} \text { ] }
\end{aligned}
$$

Solvent

$0.1 \mathrm{~m} \mathrm{HClO}$,

$0.4 \mathrm{~m} \mathrm{IiClO}$

$-54.22$

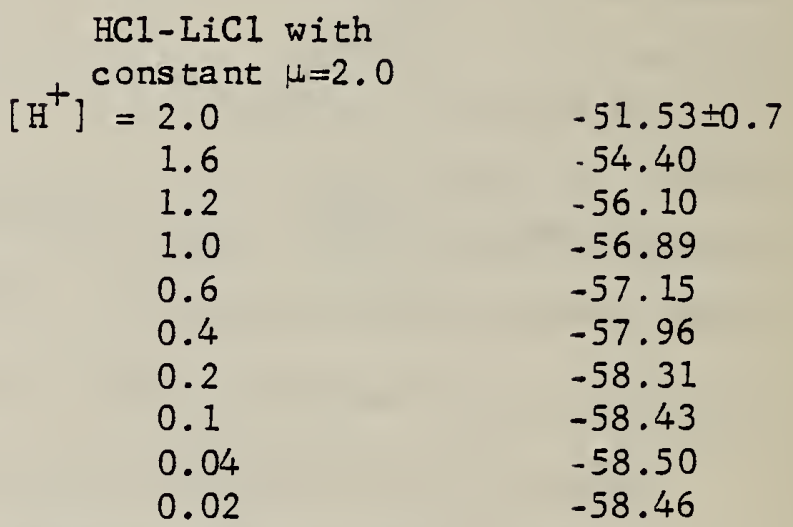

The final smoothed values recommended for $\mathrm{AH}_{\text {soln }}$ of $\mathrm{UCl}_{4}$ (c) as a function of $\mathrm{m}$ of $\mathrm{HCl}$ and $\mathrm{HClO}_{4}$ are given in Tables 7 and 8 .

\footnotetext{
* Corrected for polymerization of $U(I V)$.

Measurements by Argue are for molar concentrations.
} 
Table 7

Recommended Values of $\mathrm{\Delta H}_{\mathrm{Soln}} \mathrm{UCl}_{4}$ (c) in $\mathrm{HCl}$

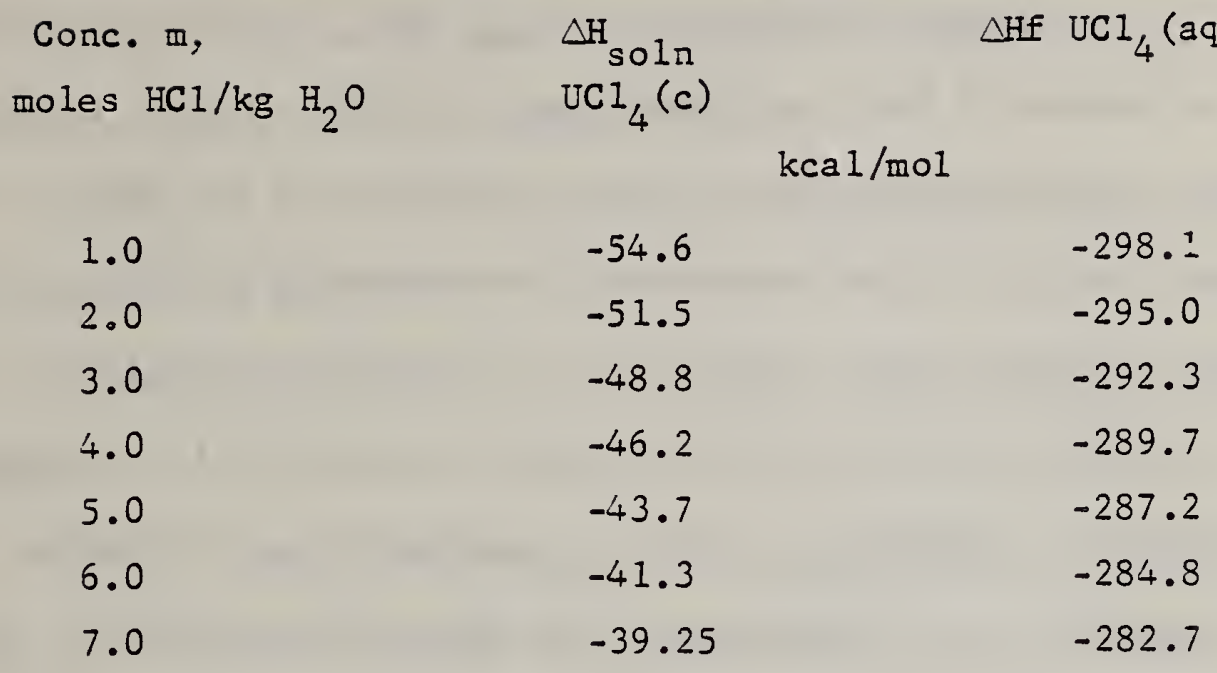

Table 8

Recommended Values of $\Delta \mathrm{H}_{\text {soln }} \mathrm{UCl}_{4}$ (c) in $\mathrm{HClO}_{4}$

Conc. m

moles $\mathrm{HOIO}_{4} / \mathrm{kg} \mathrm{H} \mathrm{H}_{2} \mathrm{O}$

0

0.1

0.5

1.0

2.0

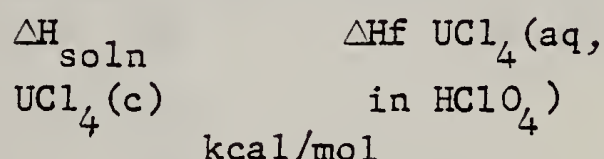

$-44.7$

$-288.5^{*}$

$-52.7$

$-296.2$

$-55.7$

$-299.2$

$-55.1$

$-298.6$

$-53.6$

This represents the 'rea $I^{\prime} \Delta \mathrm{H}_{S O l n}$ in $\mathrm{H}_{2} \mathrm{O}$, i.e. the hydrolyzed solution, not to be confused with the $\Delta \mathrm{H}^{\circ}$ soln $=(-141.3-4 \times 39.933)+243.5=-57.5$ $\mathrm{kcal} / \mathrm{mol}$ for the ideal unhydrolyzed solution $\left[\mathrm{U}^{+4}+4 \mathrm{Cl}^{-}\right]$. The difference between the two $\triangle H^{\prime} s$ soln. is a measure of $\Delta H_{\text {hydrolysis }}{ }^{\circ}$ 
$\underline{\mathrm{UC} 1_{4}(\mathrm{~g})}$

The vapor pressure measurements of Choporov and Chudinov (1968) (650-750 K; Knudsen effusion) on $\mathrm{UCl}_{4}(\mathrm{c})$ are in good agreement with the evaluation of Rand and Kubaschewski (1963); a readjustment; however, of the parameters of the $\Delta G$ expressions for $\mathrm{UCl}_{4}(1)$ (which retains the fit of the experimental measurements of Young and Grady (1958), Gregory (1948), and Jenkins and Anders on (1948)) has been made in order to obtain slightly better agreement with the measurements of Popov et al (1959a) who, from $C_{p}$ measurements, calculated the $\triangle H=$ $11.9 \mathrm{kcal} / \mathrm{mol}$ of all transformations between 834 and $882 \mathrm{~K}$ (including fusion).

The adjusted expressions are:

$$
\mathrm{UC}_{4}(\mathrm{c}) \rightarrow \mathrm{UC}_{4}(\mathrm{~g})
$$

$$
\Delta G_{1}=51,900-93.0 \mathrm{~T}+13.8 \mathrm{~T} \log \mathrm{T} \mathrm{cal} / \mathrm{mol} \text { (298-863 K) }
$$

at $298 \mathrm{~K}$ :

$$
\begin{gathered}
\Delta G^{\circ}{ }_{1}=34.3 \mathrm{kcal} / \mathrm{mol} \\
\Delta \mathrm{H}^{\circ}{ }_{1}=50.1 \mathrm{kcal} / \mathrm{mol} \\
\Delta S^{\circ}{ }_{1}=52.9 \mathrm{cal} / \mathrm{mol} \cdot \mathrm{K} \\
\mathrm{UCl}_{4}(1) \rightarrow \mathrm{UCl}_{4}(\mathrm{~g})
\end{gathered}
$$

$\Delta G_{2}=47,000-134.8 \mathrm{~T}+29.9 \mathrm{~T} \mathrm{log} \mathrm{T} \mathrm{cal} / \mathrm{mol}(863-1063 \mathrm{~K})$ at $1063 \mathrm{~K}$ :

$$
\begin{aligned}
& \Delta G=0 \\
& \Delta H=33.2 \mathrm{kcal} / \mathrm{mol} \\
& \Delta S^{\circ}=31.2 \mathrm{cal} / \mathrm{mol} \cdot \mathrm{K}
\end{aligned}
$$

The calculated tabulated values for $\Delta \mathrm{Hf}^{\circ}, \Delta G \mathrm{f}^{\circ}$ and $\mathrm{S}^{\circ}$ for $\mathrm{UV} 1_{4}(\varepsilon)$ are obtained from the sublimation process.

The earlier measurements are cited by Rand and Kubaschewskj. 
$\underline{\mathrm{UCl}_{5}(\mathrm{c}) \text { and } \mathrm{UCl}_{6}(\mathrm{c})}$

The low temperature thermal functions of $\mathrm{UCl}_{6}(\mathrm{c}), 0-350 \mathrm{~K}$, from the specific heat measurements of Fergus on and Rand (1945), have been tabulated by Katz and Rabinowitch (1951).

$\mathrm{S}^{\circ} \mathrm{UCl}_{5}(\mathrm{c})$ at $298.15 \mathrm{~K}$ has been estimated from the measured values for $\mathrm{UCl}_{4}(c)$ and $\mathrm{UCl}_{6}(c)$.

The enthalpies of formation of $\mathrm{UCl}_{5}(\mathrm{c})$ and $\mathrm{UCl}_{6}(\mathrm{c})$ are discussed together.

MacWood (1958), reporting on the experimental results of Barkelew, cites the $\Delta \mathrm{H}^{\prime} \mathrm{s}$ at $273 \mathrm{~K}$ for the oxidation of $\mathrm{UCl}_{4}(\mathrm{c})(\Delta \mathrm{H}=-24.1 \pm 0.1$ $\mathrm{kcal} / \mathrm{mol}), \mathrm{UCl}_{5}(\mathrm{c})(\Delta \mathrm{H}=-33.9 \pm 0.1 \mathrm{kcal} / \mathrm{mol})$ and $\mathrm{UCl}_{6}(\mathrm{c})(\Delta \mathrm{H}=-44.6$ $\pm 0.1 \mathrm{kcal} / \mathrm{mol}$ ) in $12 \mathrm{~N} \mathrm{HCl}, 10 \% \mathrm{FeCl}_{3}$ solutions, so that:

$$
\begin{aligned}
& \mathrm{UCl}_{4}(\mathrm{c})+\mathrm{FeCl}_{3}(\mathrm{aq}) \rightarrow \mathrm{UCl}_{5}(\mathrm{c})+\mathrm{FeCl}_{2}\left(\mathrm{a}_{1}\right) ; \Delta \mathrm{H}_{1}=9.8 \pm 0.15 \mathrm{kcal} / \mathrm{mol}(\mathrm{l}) \\
& \mathrm{UCl}_{5}(\mathrm{c})+\mathrm{FeCl}_{3}(\mathrm{soln})-\mathrm{UCl}_{6}(\mathrm{c})+\mathrm{FeCl}_{2}(\mathrm{soln}) ; \Delta \mathrm{H}_{2}=10.7 \pm 0.15 \mathrm{kcal} / \mathrm{mol}
\end{aligned}
$$

Using the relationship:

$$
\mathrm{FeCl}_{2}(\mathrm{soln})+\mathrm{Cl}_{2}(\mathrm{~g})-\mathrm{FeCl}_{3}(\mathrm{soln}) ; \Delta \mathrm{H}_{3}=-20.2 \pm 0.5 \mathrm{kcal} / \mathrm{mol}
$$

which incorporates the Barkelew experimental components and pertains to the specific medium of a $12 \mathrm{~N} \mathrm{HCl}, 10 \% \mathrm{FeCl}_{3}$ soln. at $273 \mathrm{~K}$, the following relationships are obtained:

$$
\mathrm{UCl}_{4}(\mathrm{c})+1 / 2 \mathrm{Cl}_{2}(\mathrm{~g}) \rightarrow \mathrm{UCl}_{5}(\mathrm{c}) ; \Delta \mathrm{H}_{1 \mathrm{a}}=-10.4 \pm 0.6 \mathrm{kcal} / \mathrm{mol}
$$

and

$$
\mathrm{UCl}_{5}(\mathrm{c})+1 / 2 \mathrm{Cl}_{2}(\mathrm{~g}) \rightarrow \mathrm{UCl}_{6}(\mathrm{c}) ; \Delta \mathrm{H}_{2 \mathrm{a}}=-9.4 \pm 0.6 \mathrm{kcal} / \mathrm{mol}
$$


More recently Gross et al. (1971) reported the direct chlorination of $\mathrm{U}(\mathrm{c})$ with $\mathrm{Cl}_{2}(1)$, so that:

$$
\mathrm{U}(\mathrm{c})+5 / 2 \mathrm{Cl}_{2}(\mathrm{~g}) \rightarrow \mathrm{UCl}_{5}(\mathrm{c}) ; \Delta \mathrm{H}_{4}=-247.8 \pm 1.0 \mathrm{kcal} / \mathrm{mol}
$$

which results in $\Delta \mathrm{H}_{1 \mathrm{a}}=-4.3 \pm 1.2 \mathrm{kcal} / \mathrm{mol}$.

Obviously there is a major disagreement in the relationships for $\mathrm{UCl}_{5}(c)$ and $\mathrm{UCl}_{6}(c)$. If, from Gross et al., $\Delta \mathrm{Hf}^{\circ} \mathrm{UCl}_{5}(\mathrm{c})=$ $-247.8 \mathrm{kcal} / \mathrm{mol}$ one would expect $\Delta \mathrm{H}_{2 \mathrm{a}} \approx-4$ and $\Delta \mathrm{Hf}^{\circ} \mathrm{UCI}_{6}(\mathrm{c}) \approx-252$ $\mathrm{kcal} / \mathrm{mol}$, as opposed to $\triangle \mathrm{Hf}^{\circ} \mathrm{UCl}_{5}(\mathrm{c})=-253.9$ and $\triangle \mathrm{Hf}^{\circ} \mathrm{UCl}_{6}(\mathrm{c})=$ -263.3 kcal/mol from the MacWood-Barkelew measurements. Although the Gross et al. measurements appear to be definitive for $\mathrm{UCI}_{5}(\mathrm{c})$, the overall picture they present appears unreasonable, as compared to the other halides.

The Barkelew measurements for $\Delta H$ of oxidation of $U(c)$ in this medium are known to be in error; however, some of the other measurements appear reasonable and lead to calculated values for $\Delta H f^{\circ}$ that are in agreement (within $2 \mathrm{kcal} / \mathrm{mol}$ ) with the presently accepted values, such as $\mathrm{UCl}_{3}(\mathrm{c}), \mathrm{UBr}_{4}(\mathrm{c})$, $\mathrm{UOC} 1_{2}(\mathrm{c})$ and $\mathrm{UOBr}_{2}(\mathrm{c})$. It may be that $\mathrm{AH}_{3}$ is erroneous, and that a better value is $\approx-19 \mathrm{kcal} / \mathrm{mol}$ for these conditions. See Rand and Kubaschewski (1963) for the variation of $\Delta \mathrm{H}_{3}{ }^{*}$ with $\mathrm{HCl}$ concentration. Use of $-19 \mathrm{kcal} / \mathrm{mol}$ for $\Delta \mathrm{H}_{3}$ results in: $\Delta \mathrm{H}_{\mathrm{la}}=-9.2 \mathrm{kcal} / \mathrm{mol}$ and $\Delta \mathrm{Hf}^{\circ} \mathrm{UCl}_{5}(\mathrm{c})=-252.7 \mathrm{kcal} / \mathrm{mol}$; and $\Delta \mathrm{H}_{2 \mathrm{a}}=-8.2 \mathrm{kcal} / \mathrm{mol}$ and $\Delta \mathrm{Hf}^{\circ} \mathrm{UCl}_{6}(\mathrm{c})=-260.9 \mathrm{kcal} / \mathrm{mol}$. The se values have been rounded. Further work is necessary on the $\mathrm{UCl}_{4}-\mathrm{UCl}_{5}-\mathrm{UCl}_{6}$ relationships.

* Use of $\Delta \mathrm{H}_{3} \approx-19 \mathrm{kcal} / \mathrm{mol}$ would result in $\Delta \mathrm{HF}^{\circ} \mathrm{UCl}_{3}(\mathrm{c})=-206.6$ $\mathrm{kcal} / \mathrm{mol}$ from the MacWood-Barkelew investigation, in better agreement with the selected $\triangle H^{\circ}{ }^{\circ}=-207.0$. 
The Gibbs energies of formation have been calculated from the selected $\Delta H f^{\circ}$ 's and the calculated $\Delta S f^{\circ} ' s$.

$\underline{\mathrm{UC} 1_{6}(\mathrm{~g})}$

Rand and Kubaschewski (1963) reviewed the vapor pressure data through $196 \mathrm{I}$ and reported $\Delta \mathrm{H}^{\circ}$ sub $298.15 \mathrm{~K}$ to be $18.8 \mathrm{kca} \mathrm{I} / \mathrm{mol}$ and $\Delta S^{\circ}=35.1 \mathrm{ca} 1 / \mathrm{mol} \cdot \mathrm{K}$.

The $\Delta G f^{\circ} \mathrm{UCl}_{6}(g)$ is derived from the $\Delta G^{\circ}$ subl $1^{\circ}$

$\underline{\mathrm{U}_{2} \mathrm{Cl}_{10}(\mathrm{~g})}$

Gruen and McBeth (1969) studied the reaction of $\mathrm{UCl}_{4}$ (c) with $\mathrm{Cl}_{2}(\mathrm{~g})(450-650 \mathrm{~K})$ spectrophotometrically; the uranium pentachloride was found to vaporize as a dimer molecule.

For the reaction:

$$
\begin{gathered}
2 \mathrm{UCI}_{4}(\mathrm{c})+\mathrm{Cl}_{2}(\mathrm{~g}) \rightarrow \mathrm{U}_{2} \mathrm{Cl}_{10}(\mathrm{~g}) ; \\
\Delta G=15,130-15.4 \mathrm{~T} \mathrm{cal} / \mathrm{mol}(450-650 \mathrm{~K})
\end{gathered}
$$

The Uranium Pentachloride-Aluminum Chloride Vapor Complex

Gruen and McBeth (1969) studied the reaction of $\mathrm{UCl}_{4}$ (c) with

$\mathrm{AlCl}_{3}$ (c) and $\mathrm{Cl}_{2}$ (g) spectrophotometrica $11 \mathrm{y}$; they report:

$$
\begin{gathered}
\mathrm{UCl}_{4}(\mathrm{c})+1 / 2 \mathrm{Al}_{2} \mathrm{Cl}_{6}(\mathrm{~g})+1 / 2 \mathrm{Cl} 1_{2}(\mathrm{~g}) \rightarrow \mathrm{UCl}_{5} \cdot \mathrm{AlCl}_{3}(\mathrm{~g}) \\
\Delta G=8,910-10.7 \mathrm{~T} \mathrm{cal} / \mathrm{mol}(440-630 \mathrm{~K})
\end{gathered}
$$

and

$$
\begin{aligned}
& \mathrm{UCl}_{4}(\mathrm{c})+\mathrm{Al}_{2} \mathrm{Cl} 1_{6}(\mathrm{~g}) \rightarrow \mathrm{UCl}_{4} \cdot \mathrm{Al}_{2} \mathrm{Cl}_{6}(\mathrm{~g}) \\
& \Delta \mathrm{G}=15,780-15.3 \mathrm{~T} \mathrm{caI} / \mathrm{mol}(600-800 \mathrm{~K})
\end{aligned}
$$




\subsection{U-C1-O Compounds}

$\mathrm{U} \propto \mathrm{C} 1(\mathrm{c})$ and $\operatorname{UOBr}(\mathrm{c})$

Katz and Rabinowitch (1951) tabulate the K's of Gregory (1945) for the supposed equilibrium of the $\mathrm{H}_{2}$ reduction of $\mathrm{UOX}_{2}$, where $\mathrm{X}=$ $\mathrm{Cl}$ or $\mathrm{Br}$. It was assumed that the products were $\operatorname{UOX}(\mathrm{c})$ and $\mathrm{HX}(\mathrm{g})$. No analyses of the products were made.

The $K$ 's lead to the following for:

$$
\mathrm{UOX}{ }_{2}(\mathrm{c})+1 / 2 \mathrm{H}_{2}(\mathrm{~g}) \rightarrow \mathrm{UOX}(\mathrm{c})+\mathrm{HX}(\mathrm{g})
$$

$\mathrm{X}$

$\Delta \mathrm{H}_{\mathrm{T}}$ $\mathrm{kcal} / \mathrm{mol} \mathrm{HX}$

C1

10.6

10.1
$\Delta G_{T}$

$\mathrm{kcal} / \mathrm{mol} \mathrm{HX}$

6.0

6.1
$\Delta S_{T}$ $\mathrm{cal} / \mathrm{mol} \cdot \mathrm{K}$

6.9

6.0
$T$

673

If it is assumed that the $\Delta C_{p}$ 's are negligible, the resultant $\Delta H f^{\circ}$ 's for $\operatorname{UOCl}(\mathrm{c})$ and $\operatorname{UOBr}(\mathrm{c})$ are -222 and $-213 \mathrm{kcal} / \mathrm{mol}$, respectively; however, the resultant calculated $S^{\circ}$ 's are $11 \mathrm{cal} / \mathrm{mol} \cdot \mathrm{K}$ for $\operatorname{UOCl}(\mathrm{c})$ and $12 \mathrm{cal} / \mathrm{mol} \cdot \mathrm{K}$ for $\mathrm{UOBr}(\mathrm{c})$, obviously impossible values. Reasonable values for $S^{\circ} \operatorname{UOCI}(\mathrm{c})$ and $S^{\circ} \operatorname{UOBr}(\mathrm{c})$ are $\sim 24$ and $\sim 27 \mathrm{cal} / \mathrm{mol} \cdot \mathrm{K}$, respectively (based on a comparison of the measured $S^{\circ}$ 's for $U(c)$, $\mathrm{UO}_{2}(\mathrm{c}), \mathrm{UCl}_{3}(\mathrm{c}), \mathrm{UCl}_{4}(\mathrm{c}), \mathrm{U} \propto 1_{2}, \mathrm{UO}_{2} \mathrm{Cl}_{2}$ and $\left.\mathrm{UOBr}_{2}(\mathrm{c})\right)$.

If it is assumed that the measured $K^{\prime}$ 's are reasonable, but the $T$ dependency is in error, then, with the estimated $S^{\circ}$ 's for UOC1 and $\mathrm{UOBr}$ (and assuming $\Delta \mathrm{C}_{\mathrm{p}} \approx 0$ ) one obtains $\Delta \mathrm{S}=20 \mathrm{cal} / \mathrm{mol} \cdot \mathrm{K}$ and $\Delta H=19.5 \mathrm{kcal} / \mathrm{mol}$ for the UOCl(c) equilibrium and $\Delta S=21 \mathrm{cal} / \mathrm{mol} \cdot \mathrm{K}$ and $\Delta H=20.2 \mathrm{kcal} / \mathrm{mol}$ for the $\mathrm{UOBr}(\mathrm{c})$ equilibrium. These $\Delta H^{\prime} \mathrm{s}$ result in $\triangle \mathrm{Hf}^{\circ} \mathrm{UOCl}(\mathrm{c})=-213 \mathrm{kcal} / \mathrm{mol}$ and $\triangle \mathrm{Hf}^{\circ} \mathrm{UOBr}(\mathrm{c})=-203 \mathrm{kcal} / \mathrm{mol}$ 。 However, these $\Delta H^{\circ}$ values still appear unreasonable in comparis on 
with the relationships derived for the $\operatorname{PuOCl}(c)-\operatorname{PuCl}_{3}(c), \operatorname{PuOBr}(c)-$ $\mathrm{PuBr}_{3}(\mathrm{c})$, and $\mathrm{AmOCl}(\mathrm{c})-\mathrm{AmCl}_{3}$ (c) systems from Fuger (1976). No recommendations are made at this time.

$\underline{\mathrm{UOCI}} \mathrm{C}_{2}(\mathrm{c})$

Greenberg and Westrum (1956b) measured the heat capacity from 11.7 to $348 \mathrm{~K}$ (also some measurements from 5 to $10 \mathrm{~K}$ of 1 ower precision). Thermal anomalies were not observed. The extrapolation below $10^{\circ} \mathrm{K}$ was made assuming the absence of magnetic transformation below $5 \mathrm{~K}$. Their tabulated values are accepted.

Rand and Kubaschewski (1963) evaluated the earlier measurements $(700$ to $800 \mathrm{~K})$ on the equilibria:

$$
2 \mathrm{UOCl}_{2}(\mathrm{c}) \rightarrow \mathrm{UO}_{2}(\mathrm{c})+\mathrm{UCl}_{4}(\mathrm{~g})
$$

and arrived at $\Delta H_{1}=57.1 \mathrm{kcal} / \mathrm{mol} \mathrm{UCl}_{4}$, with perfect agreement on $\Delta S^{\circ}$ from the experimental $\Delta S_{1}$ at $750 \mathrm{~K}(46.4 \mathrm{cal} / \mathrm{mol} \cdot \mathrm{K})$ and that obtained from the calorimetric $S^{\circ}$ 's for $\operatorname{UOCl}_{2}(c)$ and $\mathrm{UO}_{2}(c)$, and the calculated $\mathrm{S}^{\circ} \mathrm{UCl}_{4}(\mathrm{~g})$ obtained from the $\Delta \mathrm{S}^{\circ} \mathrm{subl} U \mathrm{UCl}_{4}$ (c) and a $\Delta C_{0}$ $=-6 \mathrm{cal} / \mathrm{mol} \cdot \mathrm{K}$. These earlier measurements will not be cited here, or reinterpreted. The resultant $\Delta \mathrm{Hf}^{\circ} \mathrm{UOCl}_{2}(\mathrm{c})=-254.9 \mathrm{kcal} / \mathrm{mol}$.

Recently Knacke et al. (1972) reported measurements on the same equilibria (in the range 700 to $1023 \mathrm{~K}$ ), which result (with a $\left.\Delta c_{p}=-6 \mathrm{cal} / \mathrm{mol} \cdot \mathrm{K}\right)$ in $\Delta H^{\circ}{ }_{1}=57.3 \mathrm{kcal} / \mathrm{mol}$, and $\Delta S^{\circ}{ }_{1}=52.4$ $\mathrm{cal} / \mathrm{mol} \cdot \mathrm{K}$, also in perfect agreement with the independently calculated $\Delta S^{\circ}$. This $\Delta H^{\circ}$ results in $\Delta \mathrm{Hf}^{\circ} \mathrm{UOCI}_{2}(\mathrm{c})=-255.0 \mathrm{kcal} / \mathrm{mol}$. 
Barkelew, as cited in MacWood (1958), calorimetrically determined the $\Delta \mathrm{HF}^{\circ}$ 's of many of the uranium-halogen containing compounds; however, his determination of $\mathrm{HHf}^{\circ} \mathrm{UCl}_{4}(\mathrm{c})$ is seriously in error because of the reaction of $\mathrm{U}(\mathrm{c})$ in $\mathrm{HCl}$; the $\Delta \mathrm{Hf}^{\circ}$ 's of $\mathrm{UCl}_{5}(\mathrm{c})$ and $\mathrm{UCl}_{6}(\mathrm{c})$ agreement with better determinations. Where possible, little weight is given to the determination, even if it is in agreement with better deteminations, but calculations will continue to be made of the $\Delta H f^{\circ}$ 's from the Barkelew data, possibly giving alternative ways of handling his data, in order to apply this knowledge to compounds where other data are scanty or non-existent.

Barkelew's measurements on $\mathrm{UOCl}_{2}$ are viewed in this regard. Since the measurement of the oxidation of $U(c)$ in a $12 \mathrm{~N} \mathrm{HC1,}$ $10 \% \mathrm{FeCl}_{3}$ is seriously in error, Barkelew's $\Delta \mathrm{H}=-16.7 \mathrm{kcal} / \mathrm{mol}$ for the oxidation of $\mathrm{UOCl}_{2}$ (c) in this medium is combined with the oxidation of $\mathrm{UCl}_{4}(\mathrm{c})$ in the same medium, $\Delta H=-24.1 \mathrm{kcal} / \mathrm{mol}$. Since the final solutions are the same, $\mathrm{UO}_{2} \mathrm{Cl}_{2}$ and $\mathrm{FeCl}_{2}$ forming in the medium:

$$
\mathrm{UCl}_{4}(\mathrm{c})+\mathrm{H}_{2} \mathrm{O}(\mathrm{aq}) \rightarrow \mathrm{UOCl}_{2}(\mathrm{c})+2 \mathrm{HCl}(\mathrm{aq}) ;{\Delta \mathrm{H}_{2}}_{2}=-7.4 \mathrm{kcal} / \mathrm{mol}
$$

Barkelew's values for $\Delta \overline{\mathrm{H}}$ 's of $\mathrm{HCl}$ and $\mathrm{H}_{2} \mathrm{O}(\mathrm{aq})$ in the $12 \mathrm{~N} \mathrm{HCl}, 10 \%$ $\mathrm{FeCl}_{3}$ medium (which are partly experimental) have been corrected for the presently accepted $\Delta \mathrm{Hf}^{\circ} \mathrm{HCl}\left(3.49 \mathrm{H}_{2} \mathrm{O}\right)=-36.05 \mathrm{kcal} / \mathrm{mol}$ and $\Delta \mathrm{Hf}^{\circ}$ $\mathrm{H}_{2} \mathrm{O}(1)=-68.315 \mathrm{kcal} / \mathrm{mol}$ and recorrected to $273 \mathrm{~K}$, incorporating the experimental determinations of $\Delta H_{\operatorname{mix}}$ and $\Delta H_{d i l n}$ to obtain for 
$\triangle \overline{\mathrm{H}} \mathrm{f}$ 's $\mathrm{HCl}$ and $\mathrm{H}_{2} \mathrm{O}$ in the medium at $273 \mathrm{~K},-32.7$ and $-69.45 \mathrm{kcal} / \mathrm{mol}$, respectively. These $\Delta H \mathrm{H}^{\prime} \mathrm{s}$ and -243.6 for $\Delta \mathrm{Hf} \mathrm{UCl}_{4}$ (c) (at $273 \mathrm{~K}$ ) result in $\Delta \mathrm{Hf}^{\circ} \mathrm{UOCl}_{2}(\mathrm{c})=-255.0$ at $273 \mathrm{~K}$ and $-254.9 \mathrm{kcal} / \mathrm{mol}$ at $298 \mathrm{~K}$. The agreement here indicates that the Barkelew-MacWood data on the reaction for $\mathrm{UOCl}_{2}(c)$ can be considered reasonable and can be used in combination with the $\Delta \mathrm{H}_{\text {reaction }}$ of $\mathrm{UOBr}_{2}(\mathrm{c})$ to obtain $\triangle \mathrm{Hf}^{\circ} \mathrm{UOBr}_{2}(\mathrm{c})$.

The Gibbs energy of formation is derived from the $\Delta S f^{\circ}$ and the $\triangle H f^{\circ}$. 
$\underline{\mathrm{UO}_{2} \mathrm{Cl}_{2}(\mathrm{c})}$

The low temperature heat capacities $(6-350 \mathrm{~K})$ have been measured by Greenberg and Westrum (1956a). The smoothed thermodynamic functions are accepted. Prins (1973) determined the high-temperature enthalpy from 392 to $696 \mathrm{~K}$ relative to $298 \mathrm{~K}$. The results are expressed as:

$$
\begin{gathered}
\mathrm{H}_{\mathrm{T}}-\mathrm{H}_{298}=22.93 \mathrm{~T}+5.562 \times 10^{-3} \mathrm{~T}^{2}+0.4643 \times 10^{5} \mathrm{~T}^{-1}-7,494 \mathrm{cal} / \mathrm{mol} \\
(298-700 \mathrm{~K})
\end{gathered}
$$

These functions join the low temperature results smoothly.

The recent measurements of Cordfunke at al.(1976) have clarified the situation regarding the $\Delta \mathrm{Hf}^{\circ} \mathrm{UO}_{2} \mathrm{Cl}_{2}(\mathrm{c})$. Two different cycles existed prior to this time for obtaining $\Delta H f^{\circ}$, both involving $\Delta H f^{\circ}$ $\mathrm{UCl}_{4}(c)$. Rand and Kubaschewski (1963) obtained $\Delta \mathrm{HF}^{\circ}=-302.9 \mathrm{kcal} / \mathrm{mol}$ (based on $\Delta \mathrm{HF}^{\circ} \mathrm{UCl}_{4}(\mathrm{c})=-251.3$ ) from the Shchukarev et al. (1958a) path which at that time was the only available one: a complete recalculation using presently accepted auxiliary $\triangle \mathrm{Hf}^{\circ}$ 's and $\triangle \mathrm{Hf}^{\circ} \mathrm{UCl}_{4}(\mathrm{c})$ $=-243.5 \mathrm{kcal} / \mathrm{mol}$ results in $\Delta \mathrm{Hf}^{\circ} \mathrm{UO}_{2} \mathrm{Cl}_{2}(\mathrm{c})=-292.0 \pm 2.0 \mathrm{kcal} / \mathrm{mol}$. The more recent cycle ${ }^{* *}$ from Khanaev and Khripin (1970) results in $-297.0 \pm 1.0 \mathrm{kcal} / \mathrm{mol}$.

\footnotetext{
* More recently Cordfunke et al. (1978) reported measurements in the range 366 to $649 \mathrm{~K}$ relative to $298 \mathrm{~K}$ :$$
\mathrm{H}_{\mathrm{T}}-\mathrm{H}_{298}=27.55 \mathrm{~T}+2.178 \times 10^{-3} \mathrm{~T}^{2}+2.729 \times 10^{5} \mathrm{~T}^{-1}-9323 \mathrm{cal} / \mathrm{mol}
$$$$
\text { At } 500 \mathrm{~K} \text { and } 700 \mathrm{~K}, \mathrm{H}_{\mathrm{T}}-\mathrm{H}_{2} \text { g are } 1 \% \text { and } 0.2 \% \text { higher than those of }
$$$$
\text { Prins (1973). }
$$

** Another value for $\Delta \mathrm{Hf}^{\circ} \mathrm{UO}_{2} \mathrm{Cl}_{2}$ (c) can be derived, $=-291.5 \mathrm{kcal} / \mathrm{mol}$, if one uses the $\Delta \mathrm{Hf}^{\circ} \mathrm{Na}_{3} \mathrm{UO}_{4}$ (c) from the mass spectrometric studies of Battles et al. (1972) in the thermochemical cycle from O'Hare et al.(1972) involving $\mathrm{Na}_{3} \mathrm{UO}_{4}(\mathrm{c})$ and $\mathrm{UO}_{2} \mathrm{Cl}_{2}(\mathrm{c})$. Since this $\triangle \mathrm{Hf}^{\circ}$ $\mathrm{Na}_{3} \mathrm{UO}_{4}(\mathrm{c})$ has a high uncertainty, a better approach is to obtain $\triangle \mathrm{Hf}^{\circ} \mathrm{UO}_{2} \mathrm{Cl}_{2}$ (c) from the other thermochemical cycles and to obtain $\triangle \mathrm{Hf}^{\circ} \mathrm{Na}_{3} \mathrm{UO}_{4}$ (c) from the $\mathrm{O}^{\prime}$ Hare measurements as has been done by Cordfunke and $0^{\prime}$ Hare (1977).
} 
Cordfunke et al. determined the $\Delta \mathrm{Hf}^{\circ}$ relative to $\Delta \mathrm{Hf}^{\circ} \mathrm{UO}_{3}(\mathrm{c}, \gamma)$ and determined $\Delta \mathrm{Hf}^{\circ} \mathrm{UO}_{2} \mathrm{Cl}_{2}(\mathrm{c})=-297.1 \pm 0.3$ and also repeated the "Shchukarev" cycle and obtained $-297.9 \pm 0.9 \mathrm{kcal} / \mathrm{mol}$.

The thermochemical cycles studied are presented, beginning with the Cordfunke "yUO ${ }_{3}$ " cycle, which is the most straightforward of the four available cycles. The measurements have been made in excess 5.545 molal HCl solutions.

$$
\begin{array}{r}
y-\mathrm{UO}_{3}(\mathrm{~s})+2 \mathrm{HCl}(\mathrm{aq}, \text { excess }) \rightarrow \mathrm{UO}_{2} \mathrm{Cl}_{2}(\text { in } \mathrm{HCl})+\mathrm{H}_{2} \mathrm{O}(\mathrm{in} \mathrm{HCl}) ; \\
\Delta \mathrm{H}_{1}=-15.53 \pm 0.07 \mathrm{kcal} / \mathrm{mol}
\end{array}
$$

so that:

$$
\begin{array}{r}
\mathrm{UO}_{3}(\mathrm{c}, \gamma)+2 \mathrm{HCl}(\mathrm{aq}, \text { excess }) \rightarrow \mathrm{UO}_{2} \mathrm{Cl}_{2}(\mathrm{c})+\mathrm{H}_{2} \mathrm{O}(\text { in } \mathrm{HCl}) ; \\
\Delta_{3}=1.53 \pm 0.09 \mathrm{kcal} / \mathrm{mol}
\end{array}
$$

With the differentials, $\Delta \overline{\mathrm{H} f} \mathrm{HCl}\left(10.01 \mathrm{H}_{2} \mathrm{O}\right)$ and $\Delta \overline{\mathrm{H}} \overline{\mathrm{H}} \mathrm{H}_{2} \mathrm{O}$ in $\mathrm{HCl} \cdot 10.01 \mathrm{H}_{2} 0$ ) $=-37.291 \pm 0.01$ and $-68.440 \pm 0.001 \mathrm{kcal} / \mathrm{mol}$, respectively, $\Delta \mathrm{Hf}^{\circ} \mathrm{UO}_{2} \mathrm{Cl}_{2}(\mathrm{c})$ $=-297.12 \pm 0.3 \mathrm{kcal} / \mathrm{mol}$.

The second of Cordfunke's cycles, the "Shchukarev cycle", and the original Shchukarev results are tabulated.

TABLE 9

The "Shchukarev cycle" for the Enthalpy of Formation of $\mathrm{UO}_{2} \mathrm{Cl}_{2}$ (c)

\section{Reaction}

(4) $\mathrm{UCl}_{4}(\mathrm{c})+2 \mathrm{FeCl}_{3}\left(\mathrm{soln}_{0}\right)+2 \mathrm{H}_{2} \mathrm{O}\left(\mathrm{soln}_{0}\right)$

$-\mathrm{UO}_{2} \mathrm{Cl}_{2}\left(\mathrm{soln}_{\bullet}\right)+2 \mathrm{FeCl}_{2}\left(\mathrm{soln} \mathrm{n}_{0}\right)+$ $4 \mathrm{HCl}$ ( $\mathrm{soln}$.)

(5) $\mathrm{UO}_{2} \mathrm{Cl}_{2}(\mathrm{c})-\mathrm{UO}_{2} \mathrm{Cl}_{2}(\mathrm{soln}$.)

(6) $2 \mathrm{FeCl}_{3}$ (c) $-2 \mathrm{FeCl}_{3}$ (soln.)

(7) $2 \mathrm{FeCl}_{2}$ (द) $\rightarrow 2 \mathrm{FeCl}_{2}$ (soln.) $\triangle \mathrm{H} \mathrm{kcal}$, mol

(Cordfunke) (Shchukarev)

The solution refers to 1.98 mass percent of $\mathrm{HC} 1$,.$\pm \dot{e} \cdot \mathrm{HCl}\left(100.6 \mathrm{H}_{2} 0\right)$

containing 0.5 mass percent of $\mathrm{FeCl}_{3}$, i.e. $\mathrm{FeCl}_{3}\left(\mathrm{I} \mathrm{OOOH} \mathrm{H}_{2} \mathrm{O}\right)$. 
From the Cordfunke Measurements:

$$
\begin{aligned}
& \mathrm{UCl}_{4}(\mathrm{c})+2 \mathrm{FeCl}_{3}(\mathrm{c})+2 \mathrm{H}_{2} \mathrm{O}(\mathrm{soln} .) \rightarrow 2 \mathrm{FeCl}_{2}(\mathrm{c})+4 \mathrm{HCl}(\mathrm{soln} .)+ \\
& \mathrm{UO}_{2} \mathrm{Cl}_{2}(\mathrm{c}) ;{\Delta \mathrm{H}_{8}}_{8}=-48.45 \pm 0.45 \mathrm{kcal} / \mathrm{mol}
\end{aligned}
$$

Using auxiliary values for $\Delta \mathrm{Hf}^{\circ} \mathrm{FeCl}_{3}(\mathrm{c}), \Delta \mathrm{Hf}^{\circ} \mathrm{FeCl}_{2}(\mathrm{c}) \Delta \overline{\mathrm{H} f}$ $\mathrm{HC} 1\left(100.6 \mathrm{H}_{2} \mathrm{O}\right)$ and $\Delta \overline{\mathrm{H} f} \mathrm{H}_{2} \mathrm{O}$ in $\mathrm{HCl} 100.6 \mathrm{H}_{2} \mathrm{O}$ ) from Parker et al. (1976), $\Delta \mathrm{Hf}^{\circ} \mathrm{UO}_{2} \mathrm{Cl}_{2}(\mathrm{c})=-297.89 \pm 0.9^{*} \mathrm{kcal} / \mathrm{mol}$.

From the Shchukarev measurements:

$$
\begin{aligned}
\mathrm{UCl}_{4}(\mathrm{c})+2 \mathrm{FeCl}_{3}(\mathrm{c})+2 \mathrm{H}_{2} \mathrm{O}\left(\mathrm{soln} \mathrm{n}_{0}\right)-\mathrm{UO}_{2} \mathrm{Cl}_{2}(\mathrm{c})+2 \mathrm{FeCl}_{2}(\mathrm{soln} .) \\
+4 \mathrm{HCl}\left(\mathrm{soln} \mathrm{n}_{\odot}\right) ; \Delta \mathrm{H}_{8 \mathrm{a}}=-81.20 \pm 0.55 \mathrm{kcal} / \mathrm{mol}
\end{aligned}
$$

The value for $\Delta \mathrm{Hf}^{\circ} \mathrm{FeCl}_{2}$ (soln.) $=-101.2 \mathrm{kcal} / \mathrm{mol}$ from Wagman et al. (1969) used to obtain the $\Delta \mathrm{HF}^{\circ} \mathrm{UO}_{2} \mathrm{Cl}_{2}(\mathrm{c})=-292.0$ cited previously was probably not appropriate for this solution; a larger uncertainty $( \pm 2.0 \mathrm{kcal} / \mathrm{mol})$ was therefore assigned to the calculated $\Delta \mathrm{Hf}^{\circ}$. Also Shchukarev's value for $\Delta \mathrm{H}_{6}$ differs considerably from that reported by Cordfunke, although the measurements for reactions (4) and (5) are in reasonable accord. If the measurements of Shchukarev for $\Delta \mathrm{H}_{4}$ and $\Delta \mathrm{H}_{5}$ are combined with Cordfunke's values for $\Delta \mathrm{H}_{6}$ and $\Delta \mathrm{H}_{7}$, $\Delta \mathrm{H}_{8}=-47.96 \pm 0.8 \mathrm{kcal} / \mathrm{mol}$ is obtained, which results in $\Delta H f^{\circ}=-297.67$ $\pm 1.0 \mathrm{kcal} / \mathrm{mol}$, in good agreement with the two Cordfunke values and that derived from the Khanaev and Khripin work cited earlier.

\footnotetext{
Cordfunke et al. (1976) at the same time measured the $\triangle \mathrm{HF}^{\circ} \mathrm{UCl}_{4}(\mathrm{c})$ $=-243.27 \pm 0.65$, relative to $\Delta \mathrm{Hf}^{\circ} \mathrm{UO}_{2}(\mathrm{c})$. This value was used to be consistent with Cordfunke's cycle.
} 
A detailed analysis of the Khanaev and Khripin measurement is given under the discussion for $\mathrm{UF}_{3}(c)$ where the summation equations are :

$$
\begin{aligned}
\mathrm{UO}_{2} \mathrm{Cl}_{2}(\mathrm{c})+3 \mathrm{FeCl}_{2}(\mathrm{c})+ & 3 \mathrm{HF}(\mathrm{aq})+\mathrm{HCl}(\mathrm{aq}) \rightarrow 2 \mathrm{H}_{2} \mathrm{O}(\mathrm{liq})+3 \mathrm{FeCl}_{3}(\mathrm{c}) \\
& +\mathrm{UF}_{3}(\mathrm{c}) ; \Delta \mathrm{H}_{9}=+29.54 \pm 0.32 \mathrm{kcal} / \mathrm{mol}
\end{aligned}
$$

and

$$
\begin{aligned}
\mathrm{FeCl}_{2}(\mathrm{c})+\mathrm{UCl}_{4}(\mathrm{c})+3 \mathrm{HF}(\mathrm{aq})-\mathrm{FeCl}_{3}(\mathrm{c})+\mathrm{UF}_{3}(\mathrm{c})+3 \mathrm{HCl}(\mathrm{aq}) ; \\
\Delta \mathrm{H}_{10}=-5.564 \pm 0.20
\end{aligned}
$$

By difference, reaction ( 8 ) is obtained with $\Delta \mathrm{H}_{8}=-35.104 \pm 0.50$ $\mathrm{kcal} / \mathrm{mol}$. However, here the $\mathrm{H}_{2} \mathrm{O} / \mathrm{HCl}$ ratio is 3.91 and the integral $\triangle \mathrm{Hf}^{\circ} \mathrm{HCl}(\mathrm{aq})=-36.449 \mathrm{kcal} / \mathrm{mol}$ is needed, resulting in the earlier mentioned $\Delta H f^{\circ}=-296.98 \pm 1.0 \mathrm{kcal} / \mathrm{mol}$.

$\Delta \mathrm{Hf}^{\circ} \mathrm{UO}_{2} \mathrm{Cl}{ }_{2}(\mathrm{c})=-297.2_{3} \pm 0.3$ is the selected value.

$\Delta G f^{\circ}$ has been calculated from $\Delta H f^{\circ}$ and $\Delta S f^{\circ}$. 
$\mathrm{UO}_{2} \mathrm{Cl}_{2}$ (in $\mathrm{HCl}$ solutions)

There are scattered values in the literature for the $\Delta H_{\text {soln }}$ of $\mathrm{UO}_{2} \mathrm{Cl}_{2}(\mathrm{c})$ in $\mathrm{HCl}$ solutions. The following table summarizes the available measurements. In all cases the concentration of the $\mathrm{UO}_{2} \mathrm{Cl}_{2}$, although different in each case, is below $1 \times 10^{-3}$ molal.

\section{Table 10}

The Enthalpy of Solution of $\mathrm{UO}_{2} \mathrm{Cl}_{2}$ in $\mathrm{HCl}$

$$
\underset{\operatorname{mol}\left(\mathrm{KgH}_{2} \mathrm{O}\right)^{-1} \quad \mathrm{kcal} / \mathrm{mol}}{\Delta \mathrm{H}_{\mathrm{soln}}}
$$

Fitzgibbon et al (1971)
Cordfunke et al (1976)
Prins (1973)
Fitzgibbon et al (1971)
O'Hare and Hoekstra (1974)
Shchukarev et al (1958a)
Cordfunke et al (1976)
O'Hare et al (1972)
O'Hare and Hoekstra (1973)

Cordfunke (1975)
6.82

5.55

5.55

4.35

1.0

$$
\begin{gathered}
0.552 \\
\left(0.5 \% \mathrm{FeCl}_{3}\right)
\end{gathered}
$$

0.552 $\left(0.5 \% \mathrm{FeCl}_{3}\right)$

\subsection{5} (containing $\mathrm{NaCl}$ )

11 $5.6 \times 10^{-4}$
$-15.34 \pm 0.5$

$-17.06 \pm 0.1$

$-17.30 \pm 0.23$

$-18.75 \pm 0.5$

$-22.18 \pm 0.15^{*}$

$-25.44 \pm 0.07$

$-24.56 \pm 0.17$

$-24.27 \pm 0.07$

$-24.19 \pm 0.09$

$-26.03 \pm 0.03$

Lipilina and Samoilov (1954) measured the $\Delta_{\text {soln }}$ of the trihydrate (using one mole of the salt in 50 moles $H_{2}$ ) as a function of the HCl concentration. The experimental $\Delta H^{\prime}$ 's have been corrected for 
the dilution of $3 \mathrm{H}_{2} \mathrm{O}(\mathrm{aq})$. These results are tabulated.

\section{Table 11}

The Enthalpy of Solution of $\mathrm{UO}_{2} \mathrm{Cl}_{2} \cdot 3 \mathrm{H}_{2} \mathrm{O}(\mathrm{c})$ in $\mathrm{HCl}$

$\begin{array}{ccc}\mathrm{m}_{\mathrm{HCl}} & \begin{array}{c}\Delta \mathrm{H}_{\exp } \\ \mathrm{kca} l / \mathrm{mol}\end{array} & \begin{array}{c}\Delta \mathrm{H} \text { corrected } \\ \mathrm{kca} 1 / \mathrm{mol}\end{array} \\ 0.80 & -8.86 & -8.86 \\ 0.97 & -8.75 & -8.74 \\ 1.55 & -7.78 & -7.75 \\ 1.98 & -6.95 & -6.91 \\ 4.44 & -2.80 & -2.56\end{array}$

In addition Prins measured $\Delta H_{\text {soln }}$ in 5.55 molal HCl (concentration of $\mathrm{UO}_{2} \mathrm{Cl}_{2} \sim .03 \mathrm{~mol} \cdot \mathrm{kg}^{-1}$ ) $=-2.41 \pm 0.01 \mathrm{kcal} / \mathrm{mol}$, which corrected for the $3 \mathrm{H}_{2} \mathrm{O}(\mathrm{aq})$ formed $=-2.04 \pm .01 \mathrm{kcal} / \mathrm{mol}$.

As can be seen from the tabulated results the data on the $\Delta H_{\text {soln }}$ $\mathrm{UO}_{2} \mathrm{Cl}_{2}$ (c) below one molal HCl are discordant; the measurements $(\mathrm{m}=$ 4.4 to 0.8 ) for $\mathrm{UO}_{2} \mathrm{Cl}_{2} \cdot 3 \mathrm{H}_{2} \mathrm{O}(\mathrm{c})$ appear to be reasonable (the concentration of the $\mathrm{UO}_{2} \mathrm{Cl}_{2}$, though, is much greater). From a smoothed plot of the $\mathrm{UO}_{2} \mathrm{Cl}_{2} \cdot 3 \mathrm{H}_{2} \mathrm{O}$ data we ojtain at $\mathrm{m}=4.40 \Delta \mathrm{H}_{\mathrm{soln}}=-2.65 \mathrm{kcal} / \mathrm{mol}$. From the $\mathrm{UO}_{2} \mathrm{Cl}_{2}(\mathrm{c})$ data $(\mathrm{m}=4.35$ to 6.82$)$ we obtain $\Delta \mathrm{H}_{\mathrm{soln}}=-18.65$ $\mathrm{kcal} / \mathrm{mol}$ for $\mathrm{m}=4.4$ If the difference in the concentrations of $\mathrm{UO}_{2} \mathrm{Cl}_{2}$ (in $\mathrm{HCl}$ ) is ignored, a $\Delta \mathrm{H}_{\text {hydration }}=-16.0 \mathrm{kcal} / \mathrm{mol}$ is obtained for:

$$
\mathrm{UO}_{2} \mathrm{Cl}_{2}(\mathrm{c})+3 \mathrm{H}_{2} \mathrm{O}(1)-\mathrm{UO}_{2} \mathrm{Cl}_{2} \cdot 3 \mathrm{H}_{2} \mathrm{O}(\mathrm{c})
$$

If, however, it is assumed that $\Delta_{L}\left(\varphi_{L} 1.11 \mathrm{~m}-\varphi_{L} \mathrm{~m}<0.001\right)=+0.5$ $\mathrm{kcal} / \mathrm{mol}$, estimated on the basis of the behavior of $\mathrm{BaCl}_{2}$ (Parker et al $(1971)), \Delta H=-15.5 \mathrm{kcal} / \mathrm{mol}$. This confirms the $\Delta \mathrm{H}_{\text {hydration }}=$ $-15.3 \pm 0.23$ from Prins (1973) measurements. In view of this confirmation, 
all measurements on $\mathrm{UO}_{2} \mathrm{Cl}_{2}(\mathrm{c})$ and $\mathrm{UO}_{2} \mathrm{Cl}_{2} \cdot 3 \mathrm{H}_{2} \mathrm{O}(\mathrm{c})$ have been merged to obtain a set of smoothed values for $\Delta \mathrm{H}_{\text {soln }} \mathrm{UO}_{2} \mathrm{Cl}_{2}(\mathrm{c})$ as a function of the $\mathrm{HCl}$ concentration ( $\mathrm{Table} 12$ ). The $\mathrm{UO}_{2} \mathrm{Cl}_{2} \cdot 3 \mathrm{H}_{2} \mathrm{O}(\mathrm{c})$ measurements were converted using the $\Delta H$ hydration $=15.3$ and $\Delta \varphi_{L}=0.5 \mathrm{kcal} / \mathrm{mol}$. The corresponding values for the $\Delta \mathrm{Hf}^{\prime} \mathrm{s}$ of $\mathrm{UO}_{2} \mathrm{C}_{2}\left(\mathrm{~m}<10^{-3}\right.$ and $\left.\mathrm{m}=1.11\right)$ are also given in Table $\mathbb{E}$. This approach supports the Cordfunke and Shchukarev measurements in the dilute region and is in agreement with a $\Delta \mathrm{H}^{\circ}=26.3 \mathrm{kcal} / \mathrm{mol}$.

Table 12 The Recomended $\Delta \mathrm{H}_{\mathrm{SOIn}} \mathrm{UO}_{2} \mathrm{Cl}_{2}(\mathrm{c})$ in $\mathrm{HC} 1$

\begin{tabular}{|c|c|c|c|}
\hline $\begin{array}{c}\mathrm{m} \\
\mathrm{HC} 1\end{array}$ & $\begin{array}{c}\triangle \mathrm{H} \text { soln } \\
\mathrm{UO}_{2} \mathrm{Cl}_{2}(\mathrm{c}) \\
\mathrm{m} \mathrm{UO}_{2} \mathrm{Cl}_{2}<10^{-3}\end{array}$ & $\begin{array}{c}\triangle \mathrm{Hf} \\
\mathrm{UO}_{2} \mathrm{Cl}_{2} \\
\mathrm{~m}<10 \\
\mathrm{kcal} / \mathrm{mol}\end{array}$ & $\begin{array}{c}\Delta \mathrm{Hf} \\
\mathrm{UO}_{2} \mathrm{Cl}_{2} \\
\mathrm{~m}=1.11\end{array}$ \\
\hline $10^{-3}$ & -26.0 & -323.2 & -322.7 \\
\hline 0.5 & -25.2 & -322.4 & -321.9 \\
\hline 1.0 & -24.3 & -321.5 & -321.0 \\
\hline 1.5 & -23.4 & -320.6 & -320.1 \\
\hline 2.0 & -22.6 & -319.8 & -319.3 \\
\hline 2.5 & -21.7 & -318.9 & -318.4 \\
\hline 3.0 & -20.9 & -318.1 & -317.6 \\
\hline 3.5 & -20.1 & -317.3 & -316.8 \\
\hline 4.0 & -19.3 & -316.5 & -316.0 \\
\hline 4.5 & -18.6 & -315.8 & -315.3 \\
\hline 5.0 & -17.8 & -315.0 & -314.5 \\
\hline 5.5 & -17.1 & -314.3 & -313.8 \\
\hline 6.0 & -16.4 & -313.6 & -313.1 \\
\hline 6.5 & -15.7 & -312.9 & -312.4 \\
\hline 7.0 & -15.1 & -312.3 & -311.8 \\
\hline
\end{tabular}

The Heat Capacity of Aqueous $\mathrm{UO}_{2} \mathrm{Cl}_{2}$ Solutions

Kapustinskii and Lipilina (1955) measured the specific heat of various aqueous solutions in the concentration range $m=0.9$ to 0.14 
mols $\left(\mathrm{kg} \mathrm{H}_{2} \mathrm{O}\right)^{-1}$. A graph of $\varphi_{C}$ (the apparent molal heat capacity) vs. $\mathrm{m}^{1 / 2}$ results in the following tabulated values:

m $\mathrm{UO}_{2} \mathrm{Cl}_{2}$

0.2

0.3

0.4

0.5

0.6

0.7

0.8

0.9

1.0
$0_{\mathrm{C}} \mathrm{cal} / \mathrm{mol} \cdot \mathrm{K}$

$-33.0$

$-28.0$

$-23.0$

$-10.5$

$-14.0$

$-10.0$

$-7.0$

$-3.0$

0 
$\mathrm{UO}_{2} \mathrm{Cl}_{2} \cdot \mathrm{H}_{2} \mathrm{O}(\mathrm{c})$ and $\mathrm{UO}_{2} \mathrm{Cl}_{2} \cdot 3 \mathrm{H}_{2} \mathrm{O}(\mathrm{c})$

The $\mathrm{S}^{\circ}$ 's at $298 \mathrm{~K}$ have been estimated from the known $\mathrm{S}^{\circ} \mathrm{UO}_{2} \mathrm{Cl}_{2}(\mathrm{c})$, the estimated contributions of the additional $\mathrm{H}_{2} \mathrm{O}$ and the Gibbs energies of formation.

There are two self contained sets of measurements on the $\Delta H^{\prime} s$ solution of the two hydrates and the anhydrous $\mathrm{UO}_{2} \mathrm{Cl}_{2}(\mathrm{c})$, those of Prins (1973) [measurements in 5N HC1], and those of Shchukarev et al (1959b) [measurements in $\mathrm{H}_{2}$ O]. The following summarizes the measurements and the calculated enthalpies of dehydration for:

$$
\mathrm{UO}_{2} \mathrm{Cl}_{2} \cdot \mathrm{nH}_{2} \mathrm{O}(\mathrm{c}) \rightarrow \mathrm{UO}_{2} \mathrm{Cl}_{2}(\mathrm{c})+\mathrm{nH}_{2} \mathrm{O}(\mathrm{I} \text { iq })
$$

\begin{tabular}{|c|c|c|c|c|}
\hline$d r$ & $\begin{array}{l}\text { Prins } \\
\Delta \mathrm{H}_{\text {soln }} \\
\text { (in } 5 \mathrm{~N} \mathrm{HCl} \text { ) }\end{array}$ & $\begin{array}{l}\text { Shchukarev et al } \\
\text { (1959 b); } \Delta \mathrm{H}_{\text {soln }} \\
\left.\text { (in } \mathrm{H}_{2} \mathrm{O}\right) \\
\text { /mol }\end{array}$ & \multicolumn{2}{|c|}{$\begin{array}{c}\Delta \mathrm{H}_{\text {dehydration }} \\
\text { kcal/mol }\end{array}$} \\
\hline 3 & $-2.41 \pm 0.01$ & $-10.00 \pm 0.11$ & $15.26 \pm 0.23^{*}$ & $13.86 \pm 0.17$ \\
\hline 1 & $-10.19 \pm 0.3$ & $-13.32 \pm 0.23$ & $7.24 \pm 0.38 *$ & $10.54 \pm 0.26$ \\
\hline 0 & $-17.30 \pm 0.23$ & $-23.86 \pm 0.13$ & - & - \\
\hline
\end{tabular}

As is obvious the results are not in agreement. Other information, though, is available which supports the Prins measurements. A detailed analysis is given elsewhere of the measurements of $\mathrm{AH}_{\text {soln }}$ of $\mathrm{UO}_{2} \mathrm{Cl}_{2}$ (c) in varying concentrations of $\mathrm{HCl}$ [from different laboratories], and the Lipilina and Samoilov (1954) measurements of the $\Delta \mathrm{H}_{\text {soln }}$ of the trihydrate in $\mathrm{HCl}$ solutions over the range $\mathrm{m}_{\mathrm{HC} 1}=0.8$ to 4.4 , where the molal concentration of $\mathrm{UO}_{2} \mathrm{Cl}_{2}$ is 1.1 (a much higher concentration of $\mathrm{UO}_{2} \mathrm{Cl}_{2}$ than for the measurements on the anhydrous). Exclusive

\footnotetext{
* Corrected for the formation of $\mathrm{H}_{2} \mathrm{O}(\mathrm{aq})$ in $5 \mathrm{~N} \mathrm{HCl}, \mathrm{H}_{2} \mathrm{O}(\mathrm{liq})-\mathrm{H}_{2} \mathrm{O}(\mathrm{aq})$; $\Delta \mathrm{H}=-0.125 \mathrm{kcal} / \mathrm{mol}$.
} 
of the Prins measurements they also result in a $\Delta H$ dehydration = 15.1 to $15.6 \mathrm{kcal} / \mathrm{mol}$, confirming the Prins (1973) relationship for the trihydrate complete dehydration. In addition, the individual measurements from Prins are in agreement with other $\Delta \mathrm{H}_{\text {soln }}$ measurements.

Now, $\Delta \mathrm{H}_{3}$ can also be obtained:

$$
\mathrm{UO}_{2} \mathrm{Cl}_{2} \cdot 3 \mathrm{H}_{2} \mathrm{O}(\mathrm{c}) \rightarrow \mathrm{UO}_{2} \mathrm{Cl}_{2} \cdot \mathrm{H}_{2} \mathrm{O}(\mathrm{c})+2 \mathrm{H}_{2} \mathrm{O}(1)
$$

which from Prins' measurements is $=8.02 \pm 0.3 \mathrm{kcal} / \mathrm{mol}$ and from Shchukarev's measurements is $=3.32 \pm 0.25 \mathrm{kcal} / \mathrm{mol}$. Cordfunke (1965) represents his vapor pressure measurements for:

$$
\mathrm{UO}_{2} \mathrm{Cl}_{2} \cdot 3 \mathrm{H}_{2} \mathrm{O}(\mathrm{c}) \rightarrow \mathrm{UO}_{2} \mathrm{Cl}_{2} \cdot \mathrm{H}_{2} \mathrm{O}(\mathrm{c})+2 \mathrm{H}_{2} \mathrm{O}(\mathrm{g})
$$

as

$$
\log P_{\text {atm }}=-3,406 \pm 32 / T+8.497 \pm 0.10
$$

This converts to:

$$
\Delta G_{4}^{\circ}=31,170-77.76 \mathrm{~T} \mathrm{cal} / \mathrm{mol}
$$

with $\Delta H_{4}^{\circ}=31.2 \pm 0.3 \mathrm{kcal} / \mathrm{mol}$ and $\Delta S_{4}^{\circ}=77.8 \mathrm{cal} / \mathrm{mol} \cdot \mathrm{K}$. Converting to equation (3) using for $\mathrm{H}_{2} \mathrm{O}(\mathrm{l}) \rightarrow \mathrm{H}_{2} \mathrm{O}(\mathrm{g}), \Delta \mathrm{H}^{\circ}=10.52 \pm 0.01 \mathrm{kcal} / \mathrm{mol}$ and $\Delta S^{\circ}=+28.4 \mathrm{cal} / \mathrm{mol} \cdot \mathrm{K}$, we obtain $\Delta H_{3}^{\circ}=+10.6 \mathrm{kcal} / \mathrm{mol}$ and $\Delta S_{3}^{\circ}=21.0 \mathrm{cal} / \mathrm{mol} \cdot \mathrm{K}$. Obviously this derived value for $\Delta H$ does not confirm either the Prins measurements or Shchukarev's; the $\Delta S^{\circ}$ for the decomposition of a hydrate should be $\approx 33-36 \mathrm{cal} / \mathrm{mol} \cdot \mathrm{H}_{2} \mathrm{O}(\mathrm{g}) \cdot \mathrm{K}$ and $\approx 5-8 \mathrm{cal} / \mathrm{mol} \cdot \mathrm{H}_{2} \mathrm{O}(\mathrm{I}) \cdot \mathrm{K}$. The derived $\Delta \mathrm{S}_{3}^{\circ}$ is $5-8 \mathrm{cal} / \mathrm{mol} \cdot \mathrm{K}$ too high. If the assumption is made that the measured pressure is 
reasonably correct, i.e., $\log \mathrm{P}_{\text {atm }}=-2.93$, then $\Delta \mathrm{G}_{4}{ }_{4}=7.98 \pm 0 . ! \mathrm{kcal}$ and with the estimate $\Delta \mathrm{S}_{4}^{\circ}=71 \mathrm{cal} / \mathrm{mol} \cdot \mathrm{K}, \Delta \mathrm{H}_{4}=29.1 \mathrm{kcal}$ and $\Delta \mathrm{H}_{3}=$ $8.1 \mathrm{kcal}$, in excellent agreement with the Prins determination.

The Prins' values for the dehydrations result in $\Delta \mathrm{Hf}^{\circ} \mathrm{UO}_{2} \mathrm{Cl}_{2} \cdot 3 \mathrm{H}_{2} \mathrm{O}(\mathrm{c})$ $=-517.4 \pm 0.4 \mathrm{kcal} / \mathrm{mol}$ and $\Delta \mathrm{Hf}^{\circ} \mathrm{UO}_{2} \mathrm{Cl}_{2} \cdot \mathrm{H}_{2} \mathrm{O}(\mathrm{c})=-372.8 \pm 0.5 \mathrm{kcal} / \mathrm{mol}$.

With an estimate of $46 \pm 2 \mathrm{cal} / \mathrm{mol} \cdot \mathrm{K}$ for $\mathrm{S}^{\circ} \mathrm{UO}_{2} \mathrm{Cl}_{2} \cdot \mathrm{H}_{2} \mathrm{O}(\mathrm{c}), \Delta \mathrm{Sf}^{\circ}$ $\mathrm{UO}_{2} \mathrm{Cl}_{2} \cdot \mathrm{H}_{2} \mathrm{O}(\mathrm{c})=-124.0 \mathrm{cal} / \mathrm{mol} \cdot \mathrm{K}$ which in combination with $\Delta \mathrm{Hf}^{\circ}$ $\mathrm{UO}_{2} \mathrm{Cl}_{2} \cdot \mathrm{H}_{2} \mathrm{O}(\mathrm{c})^{\circ}=-372.8 \pm 0.5 \mathrm{kcal} / \mathrm{mol}$ results in $\Delta G \mathrm{f}^{\circ}=-335.8 \pm 0.8$ $\mathrm{kcal} / \mathrm{mol}$.

The experimental $\Delta G_{4}^{\circ}=7.98 \pm 0.1 \mathrm{kcal} / \mathrm{mol}$, results in $\Delta G f^{\circ}$ $\mathrm{UO}_{2} \mathrm{Cl}_{2} \cdot 3 \mathrm{H}_{2} \mathrm{O}(\mathrm{c})=-453.0 \pm 0.8 \mathrm{kcal} / \mathrm{mol}$. The calculated $\mathrm{S}^{\circ} \mathrm{UO}_{2} \mathrm{Cl}_{2} \cdot 3 \mathrm{H}_{2} \mathrm{O}(\mathrm{c})$ $=65.4 \mathrm{cal} / \mathrm{mol} \cdot \mathrm{K}$ is rounded to $65 \pm 2 \mathrm{cal} / \mathrm{mol} \cdot \mathrm{K}$.

The experimental vapor pressure measurements of Cordfunke (1965), with modifications, have been used to obtain the following equation:

$$
\begin{gathered}
\mathrm{UO}_{2} \mathrm{Cl}_{2} \cdot 3 \mathrm{H}_{2} \mathrm{O}(\mathrm{c})-\mathrm{UO}_{2} \mathrm{Cl}_{2} \cdot \mathrm{H}_{2} \mathrm{O}(\mathrm{c})+2 \mathrm{H}_{2} \mathrm{O}(\mathrm{g}) \\
\Delta G^{\circ}=29,040-70.6 \mathrm{~T} \mathrm{cal} / \mathrm{mol}
\end{gathered}
$$

so that:

$$
\log P_{a t m}=-3,170 / T+7.71
$$


$\underline{\mathrm{UO}_{2} \mathrm{Cl}_{2}(\mathrm{~g})}$

Cordfunke and Prins (1974) chlorinated $\mathrm{U}_{3} \mathrm{O}_{8}(\mathrm{c})(1140-1330 \mathrm{~K})$. Volatile $\mathrm{UO}_{2} \mathrm{Cl}_{2}$ is formed. The transpiration method was used to measure the pressure of $\mathrm{UO}_{2} \mathrm{Cl}_{2}(\mathrm{~g})$ formed.

The equilibrium:

$$
\mathrm{U}_{3} \mathrm{O}_{8}(\mathrm{c})+3 \mathrm{Cl}_{2}(\mathrm{~g}) \rightarrow 3 \mathrm{UO}_{2} \mathrm{Cl}_{2}(\mathrm{~g})+\mathrm{O}_{2}(\mathrm{~g})
$$

can be expressed by:

$$
\Delta G_{\mathrm{T}}{ }^{\circ}=142,300=1600-(67.8 \pm 1.3) \mathrm{T} \mathrm{cal} / \mathrm{mol} \mathrm{O}_{2}(1140-1330 \mathrm{~K})
$$

A $\Delta C_{p}=-10 \mathrm{cal} / \mathrm{mol} \cdot \mathrm{K}$ is assumed so that at $298 \mathrm{~K}, \Delta \mathrm{H}=151.5$ $\mathrm{kcal} / \mathrm{mol}$ and $\Delta S=82 \mathrm{cal} / \mathrm{mol} \cdot \mathrm{K}$, resulting in $\Delta \mathrm{Hf}^{\circ}=-234 \pm 3 \mathrm{kcal} / \mathrm{mol}$ and $S^{\circ}=87 \pm 4 \mathrm{cal} / \mathrm{mol} \cdot \mathrm{K}$. The $S$ appears 1 ow and is not tabulated as a recommended value.

The results of Sietz cited by Kangro (1963) are not in agreement. 
$\mathrm{UOCl}_{3}(\mathrm{c})$ and $\mathrm{UOBr}_{3}(\mathrm{c})$

An estimate is given for $\operatorname{UOCl}_{3}(c) S^{\circ}=41 \pm 2$ based on the measured $S^{\circ}$ for $\mathrm{UCl}_{3}(c), \mathrm{UCl}_{4}(\mathrm{c}), \mathrm{U} \propto 1_{2}(c)$, and $\mathrm{UO}_{2} \mathrm{Cl}_{2}(\mathrm{c})$.

Similarly for $\mathrm{UOBr}_{3}(\mathrm{c})$ from the above pattern and the measured $\mathrm{UOBr}_{2}(\mathrm{c}), \mathrm{S}^{\circ}=49 \pm 3 \mathrm{cal} / \mathrm{mol}$ is estimated.

Shchukarev et al. have determined the $\Delta \mathrm{H}$ 's of reaction of $U \propto \mathrm{Cl}_{3}(\mathrm{c})$ $=-28.55 \pm 0.13(1958 \mathrm{a})$ and $\operatorname{UOBr}_{3}(c)=-45.42 \pm 0.21 \mathrm{kcal} / \mathrm{mol}(1958 \mathrm{~b})$ in $2 \% \mathrm{HCl}, 0.5 \% \mathrm{FeCl}_{3}$ solution, as well as $\mathrm{UCl}_{4}(\mathrm{c})$. [See discussion on $\left.\mathrm{UO}_{2} \mathrm{Cl}_{2}(\mathrm{c}) \cdot\right]$

The reactions of $\mathrm{UCCl}_{3}(\mathrm{c})$ and $\mathrm{UOBr}_{3}(\mathrm{c})$ involve oxidation to the (VI) state, e.g.,

$$
\mathrm{UOCl}_{3}(\mathrm{c})+\mathrm{FeCl}_{3}(\mathrm{aq})+\mathrm{H}_{2} \mathrm{O}(\mathrm{aq}) \rightarrow \mathrm{UO}_{2} \mathrm{Cl}_{2}(\mathrm{aq})+2 \mathrm{HCl}(\mathrm{aq})+\mathrm{FeCl}_{2}(\mathrm{aq})
$$

as does the reaction of $\mathrm{UCl}_{4}(c)$, so that

$$
\begin{array}{r}
\mathrm{UOCl}_{3}(\mathrm{c})+\mathrm{FeCl}_{2}(\mathrm{c})+2 \mathrm{HCl}(\mathrm{aq}) \rightarrow \mathrm{UCl}_{4}(\mathrm{c})+\mathrm{FeCl}_{3}(\mathrm{c})+\mathrm{H}_{2} \mathrm{O}(\mathrm{aq})^{*} ; \quad(1) \\
\Delta \mathrm{H}_{1}=30.90 \pm 0.22 \mathrm{kcal} / \mathrm{mol}
\end{array}
$$

and $\triangle \mathrm{Hf}^{\circ} \mathrm{UOCl}_{3}(\mathrm{c})=-277.5 \pm 0.8 \mathrm{kcal} / \mathrm{mol}$.

The difference between Shchukarev's measurements on $\mathrm{UOCl}_{3}(\mathrm{c})$ and $\mathrm{UOBr}_{3}(\mathrm{c})$ yie $\mathrm{UOCl}_{3}(\mathrm{c})+3 \mathrm{HBr}(\mathrm{aq})-\mathrm{UOBr}_{3}(\mathrm{c})+3 \mathrm{HCl}(\mathrm{aq}) ; \Delta \mathrm{H}_{2}=16.87 \pm 0.25 \mathrm{kcal} / \mathrm{mol}$

and $\triangle \mathrm{HF}^{\circ} \mathrm{UOBr}_{3}(\mathrm{c})=-228.2 \pm 0.84 \mathrm{kcal} / \mathrm{mol}$

The value for $\mathrm{UOCl}_{3}(c)$ appears to be reasonable; however, the value for $\mathrm{UOBr}_{3}(\mathrm{c})$ appears questionable; one would expect, if $\Delta \mathrm{Hf}^{\circ}$ $\mathrm{UOCl}_{3}(\mathrm{c})$ is correct, $\triangle \mathrm{Hf}^{\circ} \mathrm{UOBr}_{3}(\mathrm{c}) \approx-238 \mathrm{kcal} / \mathrm{mol}$. Since there is

\footnotetext{
As in the case of $\mathrm{UO}_{2} \mathrm{Cl}_{2}$ (c) the Cordfunke et al. (1976) measurements on $\mathrm{FeCl}_{2}(\mathrm{c})-\mathrm{FeCl}_{3}(\mathrm{c})$ are used.
} 
no other information at present to resolve this, the uncertainties have been enlarged to $\pm 5 \mathrm{kcal} / \mathrm{mol}$.

$\underline{\left(\mathrm{UO}_{2}\right)_{2} \mathrm{Cl}_{3}(\mathrm{c})}$

Cordfunke et al. (1977) have prepared a new oxide-chloride by two different methods, one the thermal decomposition of $\mathrm{UO}_{2} \mathrm{C}_{2}{ }_{2}(=)$ in vacuum at $\sim 723 \mathrm{~K}$, and the other by heating mixtures of $\mathrm{UO}_{2}(\mathrm{c})$ and $\mathrm{UO}_{2} \mathrm{Cl}_{2}$ (c) (in a molar ratio of $1: 3$ ) $773 \mathrm{~K}$. They have characterized this black-brown solid as $\left(\mathrm{UO}_{2}\right)_{2} \mathrm{Cl}_{3}(\mathrm{c})$ with an orthorhombic unit cell and have determined its $\triangle \mathrm{H}$ solution in $1.505 \mathrm{M} \mathrm{H}_{2} \mathrm{SO}_{4},(-46.025$ $\pm 0.8 \mathrm{kcal} / \mathrm{mol}$ ).

Previously Cordfunke $a \mathrm{al}$. (1976) had determined the $\Delta \mathrm{H}_{\text {soln }}$ of $\mathrm{UCl}_{4}(\mathrm{c})(-50.94 \pm 0.20)$ and $\left.\mathrm{HCl}: 10.01 \mathrm{H}_{2} \mathrm{O}\right)(-0.245 \pm 0.01)$ and Cordfunke and Ouweltjes (1977) had determined the $\Delta \mathrm{H}_{\mathrm{SOln}}$ of $\mathrm{UO}_{3}(\mathrm{c}, \gamma)$ $(-20.13 \pm 0.04 \mathrm{kca} 1 / \mathrm{mol})$, all in $1.505 \mathrm{M} \mathrm{H}_{2} \mathrm{SO}_{4}$.

A summation (after correction for dilution effects to the same final solutions) results in:

$$
\begin{array}{r}
3 \mathrm{UO}_{3}(\mathrm{c}, y)+\mathrm{UCl}_{4}(\mathrm{c})+2 \mathrm{HCl}(\mathrm{aq})^{*}-2\left(\mathrm{UO}_{2}\right)_{2} \mathrm{Cl}_{3}(\mathrm{c})+\mathrm{H}_{2} \mathrm{O}(1) ; \\
\Delta \mathrm{H}=-19.64 \pm 0.3 \mathrm{kcal} / \mathrm{mol} \mathrm{UC1} \mathrm{UC}_{4}
\end{array}
$$

The recommended value is derived from this reaction.

The integral $\Delta \mathrm{Hf}^{\circ} \mathrm{HCl} 10.01 \mathrm{H}_{2} \mathrm{O}$ 
$\mathrm{UO}_{2}(\mathrm{OH}) \mathrm{Cl} \cdot 2 \mathrm{H}_{2} \mathrm{O}(\mathrm{c})$

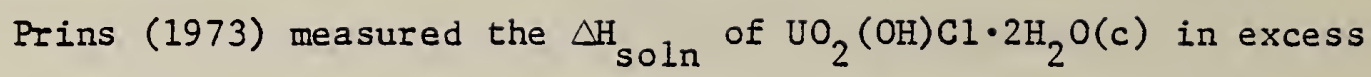
$\mathrm{HCl}\left(10.01 \mathrm{H}_{2} \mathrm{O}\right)=-2.04 \pm 0.07 \mathrm{kcal} / \mathrm{mol}$. With his $\Delta \mathrm{H}_{\mathrm{SOln}} \mathrm{UO}_{2} \mathrm{Cl}_{2} \cdot 3 \mathrm{H}_{2} \mathrm{O}(\mathrm{c})$ $=-2.4 \pm 0.01 \mathrm{kcal} / \mathrm{mol}$, one obtains the relationship:

$\mathrm{UO}_{2}(\mathrm{OH}) \mathrm{Cl} \cdot 2 \mathrm{H}_{2} \mathrm{O}(\mathrm{c})+\mathrm{HCl}(\mathrm{aq}) \rightarrow \mathrm{UO}_{2} \mathrm{Cl}_{2} \cdot 3 \mathrm{H}_{2} \mathrm{O}(\mathrm{c}) ; \Delta \mathrm{H}=0.37 \pm 0.07 \mathrm{kcal} / \mathrm{mol}$ from which $\Delta H f^{\circ}=-480.5 \pm 0.4 \mathrm{kcal} / \mathrm{mol}$. 


\section{$3.105 \quad \mathrm{U}-\mathrm{Cl}-\mathrm{F}$ Compounds}

$\mathrm{UF}_{3} \mathrm{Cl}(\mathrm{c}), \mathrm{UF}_{2} \mathrm{Cl}_{2}(\mathrm{c})$, and $\mathrm{UFCl}_{3}(\mathrm{c})$

The tabulated values for $\mathrm{S}^{\circ}, \mathrm{C}_{\mathrm{p}}{ }^{\circ}$ and $\mathrm{H}-\mathrm{H}_{0}$ are obtained from the thermal functions estimated by Maslov (1964) on the basis of $\mathrm{UF}_{4}$ (c) and $\mathrm{UCl}_{4}(\mathrm{c})(0-350 \mathrm{~K})$.

No enthalpy or Gibbs energy of formation data are available. 
$\mathrm{UBr}_{3}(\mathrm{c})$

Krestov (1972) has estimated the $C_{p}$ as a function of the temperature as:

$$
\mathrm{C}_{\mathrm{p}}=24.1+6.3 \times 10^{-3} \mathrm{~T} \mathrm{cal} / \mathrm{mol} \cdot \mathrm{K} \quad(298-1000 \mathrm{~K}) .
$$

MacWood (1958) cites the measurements of Altman (1944) and Gregory (1945) in the range $648-798 \mathrm{~K}$ on the $\mathrm{H}_{2}$ reduction equilibrium:

$$
\mathrm{UBr}_{4}(\mathrm{c})+1 / 2 \mathrm{H}_{2}(\mathrm{~g})-\mathrm{UBr}_{3}(\mathrm{c})+\mathrm{HBr}(\mathrm{g})
$$

From the $K^{\prime} s$ as a function of $T$, a second law $\Delta H^{\circ}{ }_{1}=16.0 \mathrm{kcal} / \mathrm{mol}$ $\left(\triangle \mathrm{Hf}^{\circ} \mathrm{UBr}_{3}(\mathrm{c})=-167.0 \mathrm{kcal} / \mathrm{mol}\right)$ is obtained which is in agreement with the calorimetric determinations cited below, so that this $\Delta H^{\circ}$ in conjunction with the $\Sigma\left(\mathrm{H}-\mathrm{H}_{298}\right)_{\mathrm{T}}, \Sigma\left(\mathrm{S}-\mathrm{S}_{298}\right)_{\mathrm{T}}$ and the $\mathrm{K}$ 's are used to obtain $\mathrm{S}^{\circ} \mathrm{UBr}_{4}(\mathrm{c})-\mathrm{S}^{\circ} \mathrm{UBr}_{3}(\mathrm{c})=11.0 \mathrm{cal} / \mathrm{mol}$, resulting in $\mathrm{S}^{\circ} \mathrm{UBr}_{3}(\mathrm{c})$ $=46 \pm 2 \mathrm{cal} / \mathrm{mol} \cdot \mathrm{K}$.

MacWood (1958) reporting on the measurements of Barkelew cites the $\triangle \mathrm{H}^{\prime} \mathrm{s}$ for reaction of $\mathrm{UBr}_{3}(\mathrm{c})(=-49.5 \mathrm{kcal} / \mathrm{mol})$ and $\mathrm{UCl}_{3}(\mathrm{c})(=-42.0$ kcal/mol) in solutions of $12 \mathrm{~N} \mathrm{HCl}, 10 \% \mathrm{FeCl}_{3}$. In both of these solutions the uranium is oxidized to the hexavalent state so that one can write:

$$
\mathrm{UBr}_{3}(\mathrm{c})+3 \mathrm{HCl}(\mathrm{aq}) \rightarrow \mathrm{UCl}_{3}(\mathrm{c})+3 \mathrm{HBr}(\mathrm{aq}) ; \Delta \mathrm{H}_{2}=-7.5 \mathrm{kcal} / \mathrm{mol}
$$

with $\Delta \overline{\mathrm{H}} \mathrm{f}^{\circ} \mathrm{HCl}(\mathrm{aq})=-32.7$ and $\Delta \overline{\mathrm{H}} \mathrm{HBr}(\mathrm{aq})=-22.0 \mathrm{kcal} / \mathrm{mol}$ which are consistent with Barkelew's experimental components, $\triangle H f^{\circ} \operatorname{UBr}_{3}(c)=$ $-167.4 \mathrm{kcal} / \mathrm{mol}$.

One can also use the measurement of $\mathrm{UBr}_{4}(\mathrm{c})$ in the same media $(\Delta H=-33.1 \mathrm{kca} 1 / \mathrm{mol})$ to obtain the relationship:

$$
\begin{array}{r}
\mathrm{UBr}_{3}(\mathrm{c})+\mathrm{HBr}(\mathrm{aq})+\mathrm{FeCl}_{3}(\mathrm{aq})-\mathrm{UBr}_{4}(\mathrm{c})+\mathrm{FeCl}_{2}(\mathrm{aq})+\mathrm{HCl}(\mathrm{aq}) ; \\
\Delta \mathrm{H}_{3}=-16.4 \mathrm{kcal} / \mathrm{mol}
\end{array}
$$


With the Barkelew relationship ( $\triangle \mathrm{H}=-20.2 \mathrm{kcal} / \mathrm{mol})$ cited previously (see $\mathrm{UCl}_{5}(c)$ and $\mathrm{UCl}_{6}(c)$ ) for the $\mathrm{FeCl}_{2}-\mathrm{FeCl}_{3}$ relationship, $\triangle \mathrm{Hf}{ }^{\circ}$ $\mathrm{UBr}_{3}(\mathrm{c})=-165.8 \mathrm{kcal} / \mathrm{mol}$. This provides a crosscheck. As cited previously, the high temperature equilibrium studies result in $\Delta \mathrm{HF}^{\circ}=-167.0 \mathrm{kcal} / \mathrm{mol}$. The selected value is $\Delta \mathrm{Hf}^{\circ}=$ $-167.0 \pm 1.0 \mathrm{kca} 1 / \mathrm{mol}$.

The Gibbs energy of formation is derived from the selected $\Delta \mathrm{Hf}^{\circ}$ and $\Delta S f^{\circ}=-20.6 \mathrm{cal} / \mathrm{mol} \cdot \mathrm{K}$. 
Rand and Kubaschewski (1963), using the information given by Katz and Rabinowitch (1951) on the vapor pressure of $\mathrm{UBr}_{3}(c, 1)$ (measurements by Altman and by Webster), obtained the following:

$$
\begin{aligned}
& \mathrm{UBr}_{3}(\mathrm{c}) \rightarrow \mathrm{UBr}_{4}(\mathrm{~g}) \\
& \Delta G=75,100-91.8 \mathrm{~T}+13.8 \mathrm{~T} \log \mathrm{T} \mathrm{ca} 1 / \mathrm{mol} \\
& \text { (298 to } 1000 \mathrm{~K} \text { ) } \\
& \text { at } 298 \mathrm{~K}: \Delta \mathrm{H}=73.4 \mathrm{kcal} / \mathrm{mol} \\
& \Delta S=51.6 \mathrm{ca} 1 / \mathrm{mol} \cdot \mathrm{K} \\
& \Delta G=58.0 \mathrm{kcaI} / \mathrm{mol} \\
& \mathrm{UBr}_{3}(1) \rightarrow \mathrm{UBr}_{3}(\mathrm{~g}) \\
& \Delta G=68,600-112.8 \mathrm{~T}+23.0 \mathrm{~T} \log \mathrm{T} \mathrm{cal} / \mathrm{mol} \\
& \text { (1000 to } 1810 \mathrm{~K} \text { ) } \\
& \Delta G=0 \text { at } 1810 \mathrm{~K} \\
& \text { and } \\
& \Delta \mathrm{H}=50.5 \mathrm{kca} 1 / \mathrm{mol} \\
& \Delta S=27.9 \mathrm{ca} 1 / \mathrm{mol} \cdot \mathrm{K} \\
& \mathrm{UBr}_{3}(\mathrm{c}) \rightarrow \mathrm{UBr}_{3}(1) \\
& \Delta \mathrm{H}=10.5 \mathrm{kca} 1 / \mathrm{mol} \\
& \Delta S=10.5 \mathrm{ca} 1 / \mathrm{mol} \cdot \mathrm{K}
\end{aligned}
$$

These values are accepted. 
$\underline{\mathrm{UBr}_{4}(\mathrm{c})}$

$\mathrm{S}^{\circ}$ has been estimated as $57.0 \pm 2.0 \mathrm{cal} / \mathrm{mol}$. Krestov (1972) has estimated the $\mathrm{C}_{\mathrm{p}} \mathrm{UBr}_{4}$ (c) as:

$$
\mathrm{C}_{\mathrm{p}}=28.5+.0071 \mathrm{~T} \mathrm{cal} / \mathrm{mol} \cdot \mathrm{K}(298-792 \mathrm{~K})
$$

From the discussion on $\operatorname{UBr}_{4}(\mathrm{~g})$ we have, at the melting point, $792 \mathrm{~K}$ :

$$
\begin{aligned}
& \Delta \mathrm{H}_{\text {fusion }}=11.6 \mathrm{kcal} / \mathrm{mol} \\
& \Delta \mathrm{S}_{\text {fusion }}=14.6 \mathrm{cal} / \mathrm{mol} \cdot \mathrm{K} \\
& \mathrm{C}_{\mathrm{p}}(1)=41 \mathrm{cal} / \mathrm{mol} \cdot \mathrm{K}
\end{aligned}
$$

Fuger and Brown (1973) measured $\triangle \mathrm{H}^{\prime} \mathrm{s}$ of soln. of $\mathrm{UBr}_{4}$ (c) and $\mathrm{UCl}_{4}(\mathrm{c}$ ) in $1 \mathrm{M} \mathrm{HCl}$ solutions, i.e., $\mathrm{HCl}\left(54.4 \mathrm{H}_{2} \mathrm{O}\right)$ of $-63.24 \pm 0.09$ and $-54.46 \pm 0.23$ $\mathrm{kcal} / \mathrm{mol}$, respectively. From these measurements the following is obtained :

$$
\mathrm{UBr}_{4}(\mathrm{c})+4 \mathrm{HCl}(\mathrm{aq}) \rightarrow \mathrm{UCl}_{4}(\mathrm{c})+4 \mathrm{HBr}(\mathrm{aq}) ; \Delta \mathrm{H}_{1}=-8.78 \pm 0.25 \mathrm{kcal} / \mathrm{mol}
$$

It is assumed that the formation of $\mathrm{HBr}$ in a $1 \mathrm{M} \mathrm{HCl}$ solution is equivalent to the formation of an additional mole of $\mathrm{HBr}$ in an $\mathrm{HBr}$ $1 M$ solution. Using differential $\triangle \bar{H} f^{\prime} ' s$, then for $\mathrm{HCl}$ and $\mathrm{HBr}$ of -39.284 and $-28.53 \mathrm{kcal} / \mathrm{mol}$, respectively, $\Delta \mathrm{Hf}^{\circ}$ of $\mathrm{UBr}_{4}(\mathrm{c})=-191.70$ $\pm 0.7 \mathrm{kcal} / \mathrm{mol}$.

Shchukarev et al (1959a) measured the $\Delta \mathrm{H}$ for the reaction of $\mathrm{UBr}_{4}$ (c) wit $2 \% \mathrm{HCl}, 0.5 \% \mathrm{FeCl}_{3}$ solution as $-53.27 \pm 0.36 \mathrm{kcal} / \mathrm{mol}$. In an earlier report (1958a) they measured the $\triangle \mathrm{H}$ for reaction of $\mathrm{UCl}_{4}$ (c) as $-45.50 \pm 0.10$ $\mathrm{kcal} / \mathrm{mol}$ in a similar solution. These reactions involve oxidation to $\mathrm{UO}_{2} \mathrm{Cl}_{2}$ (in $\mathrm{HCl}$ ) as :

$$
\begin{aligned}
\mathrm{UBr}_{4}(\mathrm{c})+2 \mathrm{FeCl}_{3}(\mathrm{aq})+2 \mathrm{H}_{2} \mathrm{O}(1) \rightarrow \mathrm{UO}_{2} \mathrm{Cl}_{2}(\mathrm{aq})+2 \mathrm{FeCl}_{2}(\mathrm{aq}) \\
+4 \mathrm{HBr}(\mathrm{aq})
\end{aligned}
$$


By difference, though, one obtains $\Delta \mathrm{H}_{1}=-7.77 \pm 0.37 \mathrm{kcal} / \mathrm{mol}$ and with the same assumptions as earlier regarding the use of the differentials and with $\triangle \overline{\mathrm{HF}} \mathrm{HCl}\left(100 \mathrm{H}_{2} \mathrm{O}\right)$ and $\overline{\mathrm{H}} f \mathrm{HBr}\left(100 \mathrm{H}_{2} \mathrm{O}\right)=$ -39.489 and $-28.692 \mathrm{kcal} / \mathrm{mol}$, respectively, $\Delta \mathrm{Hf}^{\circ} \mathrm{HBr}_{4}(\mathrm{c})=-192.5_{4} \pm 0.8$.

Similarly, Vdovenko et al (1973) obtain $\triangle \mathrm{H}$ for $\mathrm{UBr}_{4}(\mathrm{c})$ to be $-54.32 \pm 0.1$, and $-45.34 \pm 0.1$ for $\mathrm{UCl}_{4}(\mathrm{c})$, from which $\Delta \mathrm{H}_{1}=-8.98 \pm 0.14$ and $\Delta H f^{\circ}=-191.4 \pm 0.6 \mathrm{kcal} / \mathrm{mol}$.

MacWood (1958), reporting on the measurements of Barkelew (1946) cites the $\triangle \mathrm{H}^{\prime} \mathrm{s}$ at $273 \mathrm{~K}$ of the reaction of $\mathrm{UCl}_{4}(\mathrm{c})$ and $\mathrm{UBr}_{4}(\mathrm{c})$ in $12 \mathrm{~N}$ $\mathrm{HCl}, 10 \% \mathrm{FeCl}_{3}$ solutions, from which $\Delta \mathrm{H}_{1}=-9.0 \mathrm{kcal} / \mathrm{mol}$. With their values for $\Delta \bar{H}{ }^{\prime}$ 's of $\mathrm{HCl}$ and $\mathrm{HBr}=-32.7$ and $-22.0 \mathrm{kcal} / \mathrm{mol}$, respectively (these values for the differentials at $273 \mathrm{~K}$ incorporate the Barkelew experimental components), $\Delta H f^{\circ}=-191.8 \pm 2.0 \mathrm{kcal} / \mathrm{mol}$.

A weighted average results in $\Delta \mathrm{Hf}^{\circ}=-191.7 \pm 0.6 \mathrm{kcal} / \mathrm{mol}$. The $\Delta \mathrm{Sf}^{\circ}=-27.77 \mathrm{cal} / \mathrm{mol} \cdot \mathrm{K}$ and the $\Delta \mathrm{Hf^{ \circ }}$ results in $\Delta \mathrm{Gf} \mathrm{f}^{\circ}=$ $-183.4 \pm 0.9 \mathrm{kcal} / \mathrm{mol}$. 
$\underline{\mathrm{UBr}} 4 \mathrm{~g})$

Rand and Kubaschewski (1963) reviewed the vapor pressure data on the crystal and liquid and using an estimated $\Delta C_{p}=-6 \mathrm{cal} / \mathrm{mol} \cdot \mathrm{K}$ obtained for the sublimation process, (from the excellent agreement in the measurements of Thompson and Schelberg ( $573 \mathrm{~K}-723 \mathrm{~K}$; effusion) and Nottorf and Powe 11 (723-773; gas saturation) given by Katz and Rabinowitch (1951)):

$$
\begin{gathered}
\operatorname{UBr}_{4}(\mathrm{c}) \rightarrow \mathrm{UBr}_{4}(\mathrm{~g}) \\
\Delta G^{\circ}=49,400-92.7 \mathrm{~T}+13.8 \mathrm{~T} \text { log } \mathrm{T} \mathrm{cal} / \mathrm{mol}
\end{gathered}
$$

These results lead to, at $298.15 \mathrm{~K}$ :

$$
\begin{aligned}
\Delta H^{\circ} & =47.6 \mathrm{kcal} / \mathrm{mol} \\
\Delta G^{\circ} & =31.9 \mathrm{kca} 1 / \mathrm{mol} \\
\Delta S^{\circ} & =52.6 \mathrm{ca} 1 / \mathrm{mol} \cdot \mathrm{K}
\end{aligned}
$$

These values are accepted in the absence of newer data.

A similar equation, with $\Delta_{p}=-11$ for the vaporization process

$$
\mathrm{UBr}_{4}(1) \rightarrow \mathrm{UBr}_{4}(\mathrm{~g})
$$

results in $\Delta \mathrm{H}_{\text {fusion }}$ at the melting point, $792 \mathrm{~K},=13.2 \mathrm{kcal} / \mathrm{mol}$ and a $\Delta S_{\text {fusion }}=16.5 \mathrm{cal} / \mathrm{mol} \cdot \mathrm{K}$.

In view of the large $\Delta S_{\text {fusion }}$ a reexamination of the vapor pressure data was made using the measurements of Gregory (815-1033 K; boiling point), and Nottorf and Powell (798-898; gas saturation) as given by Mueller (1948). The measurements (although there is some scatter) are in agreement, and with $\Delta_{p}=-13 \mathrm{cal} / \mathrm{mol} \cdot \mathrm{K}$, the following is obtained:

$$
\Delta G^{\circ}=43,300-131.9 \mathrm{~T}+29.9 \mathrm{~T} \text { log } \mathrm{T} \mathrm{cal} / \mathrm{mol}
$$


$\Delta G^{\circ}=0$ at $1040 \mathrm{~K}, \Delta H=29.8 \mathrm{kcal} / \mathrm{mol}$ and $\Delta S=28.6 \mathrm{cal} / \mathrm{mol} \cdot \mathrm{K}$.

At $792 \mathrm{~K}$ (melting point):

$$
\begin{aligned}
\Delta H & =11.6 \mathrm{kcal} / \mathrm{mol} \\
\Delta \mathrm{S} & =14.6 \mathrm{ca} 1 / \mathrm{mol} \cdot \mathrm{K}
\end{aligned}
$$

$\mathrm{UBr}_{5}(\mathrm{c})$

$$
\text { Krestov's (1972) estimated } C_{p}=36.0+8.0 \times 10^{-3} \mathrm{~T} \mathrm{cal} / \mathrm{mol} \cdot \mathrm{K}
$$

is accepted. The $\mathrm{S}^{\circ}$ was estimated as $70 \pm 3 \mathrm{cal} / \mathrm{mol} \cdot \mathrm{K}$. These values result in a reasonable fit of the Blair and Ihle (1973) thermal decomposition measurements of $\mathrm{UBr}_{5}(\mathrm{c})$ to a third law plot.

The thermal decomposition of $\mathrm{UBr}_{5}(\mathrm{c})$ was studied in the range $298-400 \mathrm{~K}$.

$$
\mathrm{UBr}_{5}(\mathrm{c}) \rightarrow \mathrm{UBr}_{4}(\mathrm{c})+1 / 2 \mathrm{Br}_{2}(\mathrm{~g})
$$

The decomposition is reversible below $353 \mathrm{~K}$. Above this temperature the compound decomposes irreversibly into $\mathrm{UBr}_{4}$ (c) and $\mathrm{Br}_{2}$ (1). From the vapor pressure measurements below $383 \mathrm{~K}$ a third law $\Delta H^{\circ}=6.0$ $\mathrm{kca} 1 / \mathrm{mol}\left(\Delta \mathrm{HF}^{\circ}=-194.0 \mathrm{kcal} / \mathrm{mol}\right)$. A second law $\Delta \mathrm{H}=5.4 \mathrm{kcal} / \mathrm{mol}$ $\left(\Delta \mathrm{HF}^{\circ}=-193.4 \mathrm{kcal} / \mathrm{mol}\right)$. The average $\Delta \mathrm{HF}^{\circ} \mathrm{UBr}_{5}(\mathrm{c})=-193.7 \pm 2.0$ $\mathrm{kcal} / \mathrm{mol}$ is selected. The $\Delta G \mathrm{f}^{\circ}$ is calculated from the $\Delta H \mathrm{f}^{\circ}$ and the estimated $\triangle S f^{\circ}$. 


\section{$3.107 \quad \mathrm{U}-\mathrm{Br}-\mathrm{O}$ Compounds}

$\mathrm{UOBr}(\mathrm{c})$

See $U \propto C 1(c)$

$\underline{\mathrm{UOBr}} \mathrm{T}_{2}(\mathrm{c})$

The $\mathrm{S}^{\circ}, \mathrm{C}_{\mathrm{p}}{ }^{\circ}$, and $\mathrm{H}-\mathrm{H}_{0}$ are from Greenberg and Westrum's (1956b) tabulation from their heat capacity measurements from $5 \mathrm{~K}$ to $339 \mathrm{~K}$.

Meller (1948) reported the vapor pressure measurements of $\mathrm{UBr}_{4}(\mathrm{~g})$ over $\mathrm{UOBr}_{2}$ (c) from the results of Gregory. For the range 710 to $960 \mathrm{~K}$,

$$
\log P(\mathrm{~atm})=-10,870 / \mathrm{T}+8.32
$$

$\Delta \mathrm{H}=49.7 \mathrm{kcal} / \mathrm{mol} \mathrm{UBr}_{4}$ at the mean temperature for:

$$
2 \mathrm{UOBr}_{2}(\mathrm{c}) \rightarrow \mathrm{UBr}_{4}(\mathrm{~g})+\mathrm{UO}_{2}(\mathrm{c})
$$

which, with $\Delta C_{p}=-6 \mathrm{cal} / \mathrm{mol} \cdot \mathrm{K}$ results in $\Delta H_{1}=52.9 \mathrm{kcal} / \mathrm{mol}$ and $\Delta H f^{\circ}=-228.2 \mathrm{kcal} / \mathrm{mol}$. However, the $\Delta S_{I}^{\circ}=38.1 \mathrm{cal} / \mathrm{mol} \cdot \mathrm{K}$ at the mean temperature results in a $\Delta S^{\circ}$ at $298 \mathrm{~K}=44 \mathrm{cal} / \mathrm{mol} \cdot \mathrm{K}$, whereas the value calculated from the $\mathrm{S}^{\circ}$ 's of $\mathrm{UO}_{2}(\mathrm{c}), \mathrm{UOBr}_{2}(\mathrm{c})$ and $\mathrm{UBr}_{4}(\mathrm{~g})$ [obtained from $\Delta S^{\circ}$ subl and an estimate for $S^{\circ} \operatorname{UBr}_{4}\left(\right.$ c)] results in $\Delta S_{1}^{\circ}$ $=53 \mathrm{cal} / \mathrm{mol} \cdot \mathrm{K}$. The difference in $\Delta S^{\circ}$ is too great to be rationalized; the $\mathrm{S}^{\circ} \mathrm{UBr}_{4}(\mathrm{~g})$ accepted here does not appear to be appreciably too high since $110 \mathrm{cal} / \mathrm{mol} \cdot \mathrm{K}$ is reasonable with regard to $\mathrm{S}^{\circ} \mathrm{UCl}_{4}(\mathrm{~g})$ obtained from $\Delta S^{\circ}$ subl $\mathrm{UCl}_{4}(c)$ which is in excellent agreement with the value obtained from the comparable $U O C 1_{2}$ (c) decomposition to $\mathrm{UCl}_{4}(\mathrm{~g})$ 
In addition, using the $\Delta \mathrm{Hf}^{\circ} \mathrm{UOBr}_{2}(\mathrm{c})=-228.2 \mathrm{kcal} / \mathrm{mol}$ for

$$
2 \mathrm{UOBr}_{2}(\mathrm{c}) \rightarrow \mathrm{UO}_{2}(\mathrm{c})+\mathrm{UBr}_{4}(\mathrm{c}),
$$

$\Delta \mathrm{H}_{2}=5.4 \mathrm{kcal} / \mathrm{mol} \mathrm{UBr}_{4}(\mathrm{c})$ which indicates a lower stability for $\mathrm{UOBr}_{2}$ (c) than for $\mathrm{UCCl}_{2}$ (c). Again this does not seem reasonable.

For these reasons the Gregory data has been rearranged by:

1. Assuming that his pressure measurements are reasonable, with $\log P(a t m)=-4.47$ at $850 \mathrm{k}$ (obtained from his equation).

2. Assuming $\Delta S^{\circ}{ }_{1}$ at $850 \mathrm{~K} \approx 47 \mathrm{cal} / \mathrm{mol} \cdot \mathrm{K}$ (using the $\Delta S^{\circ}{ }_{1}$ at $298 \mathrm{~K}$ $53 \mathrm{cal} / \mathrm{mol} \cdot \mathrm{K}$ and $\left.\Delta \mathrm{C}_{\mathrm{p}}{ }^{0}=-6 \mathrm{cal} / \mathrm{mol} \cdot \mathrm{K}\right)$.

3. Recalculating $\Delta \mathrm{H}_{1}$ at $850 \mathrm{~K}$ to be $57.3 \mathrm{kcal} / \mathrm{mol}$ from the above listed values for $\log P$ and $\Delta S^{\circ}$ results in $\Delta \mathrm{H}^{\circ}{ }_{1}$ at $298 \mathrm{~K}=60.6 \mathrm{kcal} / \mathrm{mol}$.

The resultant $\Delta \mathrm{Hf}^{\circ} \mathrm{UOBr}{ }_{2}(\mathrm{c})=-232.0 \mathrm{kcal} / \mathrm{mol}$.

The Barkelew (1946) measurements on the oxidation reactions of (1) $\mathrm{UOBr}_{2}$ (c) and (2) $\mathrm{UOCl}_{2}$ (c) in a $12 \mathrm{~N} \mathrm{HCl}, 10 \% \mathrm{FeCl}_{3}$ aqueous solution at $273 \mathrm{~K}$ are now considered. As indicated in the discussion on $U \propto \mathrm{Cl}_{2}(\mathrm{c})$ the values obtained for the $\Delta \mathrm{Hf}^{\circ} \mathrm{UOC1_{2 }}(\mathrm{c})$ from the Barkelew data are in reasonable agreement with the preferred data, although the sample of $\mathrm{UOCl}_{2}(c)$ used was not of high purity.

The $\triangle \mathrm{H}$ of oxidation of $\mathrm{UOBr}_{2}(\mathrm{c})$ in a $12 \mathrm{~N} \mathrm{HCl}, 10 \% \mathrm{FeCl}_{3}$ aqueous solution $=-16.3 \mathrm{kcal} / \mathrm{mol}$. This reaction was paired with the comparable reaction of $\mathrm{UOCl}_{2}(\mathrm{c}), \Delta \mathrm{H}=-16.7 \mathrm{kcal} / \mathrm{mol}$, te obtain $\Delta \mathrm{H}_{3}$ at $273 \mathrm{~K}=$ $-0,4 \mathrm{kcal} / \mathrm{mol}$ for

$$
\mathrm{UOCl}_{2}(\mathrm{c})+2 \mathrm{HBr}(\mathrm{aq}) \rightarrow \mathrm{UOBr}_{2}(\mathrm{c})+2 \mathrm{HCl}(\mathrm{aq}) .
$$

As for the differential $\triangle \bar{H} f \mathrm{HCl}(\mathrm{aq})$, the Barkelew value for the differential $\triangle \bar{H} f$ of $\mathrm{HBr}(\mathrm{aq})$ in a $12 \mathrm{~N} \mathrm{HCl}, \mathrm{FeCl}_{3}$ aqueous solution has 
been recalculated equal to $-22.03 \mathrm{kcal} / \mathrm{mol}$ at $273 \mathrm{~K}$ (this value incorporated Barkelew's experimental components), so that $\Delta H^{\circ}$ at $273 \mathrm{~K}$ $=-234.2$ for $\mathrm{UOBr}_{2}(\mathrm{c})$ and $\Delta \mathrm{Hf}^{\circ}$ at $298 \mathrm{~K}=-234.1 \mathrm{kcal} / \mathrm{mol}$.

None of these values by themselves can be considered good.

However, the recalculations have brought them, from very different paths, into reasonable agreement.

$\triangle \mathrm{Hf}^{\circ} \mathrm{UOBr}_{2}(\mathrm{c})$ has been taken to be $-232.7 \pm 2.0 \mathrm{kcal} / \mathrm{mol}$. This value results in $\Delta \mathrm{H}_{3}=14.4 \mathrm{kcal} / \mathrm{mol} \mathrm{UBr}_{4}(\mathrm{c})$.

The $\triangle G f^{\circ}$ is calculated from the $\Delta H f^{\circ}$ and $S^{\circ}$. 
$\mathrm{UO}_{2} \mathrm{Br}_{2} \cdot \mathrm{nH}_{2} \mathrm{O}(\mathrm{c})(\mathrm{n}=0,1,3)$

The entropy for $\mathrm{UO}_{2} \mathrm{Br}_{2}$ (c) at $298 \mathrm{~K}$ is estimated on the basis of the values for $\mathrm{UOCl}_{2}(\mathrm{c}), \mathrm{UOBr}_{2}(\mathrm{c})$, and $\mathrm{UO}_{2} \mathrm{Cl}_{2}(\mathrm{c})$; those for the hydrates using a contribution to $\mathrm{S}^{\circ}$ of $9.4 \mathrm{cal} / \mathrm{mol} \cdot \mathrm{K}$ per mole of $\mathrm{H}_{2} \mathrm{O}$.

Recently Cordfunke et al. (1978) determined the enthalpy of $\mathrm{UO}_{2} \mathrm{Br}_{2}(\mathrm{c})$ in the range 345 to $454 \mathrm{~K}$ relative to $298 \mathrm{~K}$. The results are expressed as:

$$
\begin{gathered}
\mathrm{H}_{\mathrm{T}}-\mathrm{H}_{298}=24.92 \mathrm{~T}+4.534 \times 10^{-3} \mathrm{~T}^{2}-7833 \mathrm{ca} 1 / \mathrm{mol} \\
(298-460 \mathrm{~K})
\end{gathered}
$$

The values for the $\Delta H f^{\circ}$ 's are obtained from the recent measurements of Prins et al. (1978) on the $\Delta \mathrm{H}^{\prime} \mathrm{s}$ of solution of $\mathrm{UO}_{3}(\mathrm{c}, \gamma), \mathrm{UO}_{2} \mathrm{Br}_{2} \cdot 0.024 \mathrm{H}_{2} \mathrm{O}(\mathrm{c})$ $\mathrm{UO}_{2} \mathrm{Br}_{2} \cdot 1.05 \mathrm{H}_{2} \mathrm{O}(\mathrm{c})$ and $\mathrm{UO}_{2} \mathrm{Br}_{2} \cdot 2.92 \mathrm{H}_{2} \mathrm{O}(\mathrm{c})$ in excess $\mathrm{HBr}\left(14.63 \mathrm{H}_{2} \mathrm{O}\right)$. The $\Delta H^{\prime}$ 's are given, corrected to the appropriate hydrates.

$$
\begin{array}{lc}
\text { Compound } & \begin{array}{c}
\Delta \mathrm{H}_{\mathrm{soln}} \\
\mathrm{kcal} / \mathrm{mol}
\end{array} \\
\mathrm{UO}_{3}(\mathrm{c}, \gamma) & -17.88 \pm 0.05 \\
\mathrm{UO}_{2} \mathrm{Br}_{2}(\mathrm{c}) & -25.38 \pm 0.10 \\
\mathrm{UO}_{2} \mathrm{Br}_{2} \cdot \mathrm{H}_{2} \mathrm{O}(\mathrm{c}) & -17.61 \pm 0.15 \\
\mathrm{UO}_{2} \mathrm{Br}_{2} \cdot 3 \mathrm{H}_{2} \mathrm{O}(\mathrm{c}) & -10.43 \pm 0.20
\end{array}
$$

The $\triangle \mathrm{Hf}^{\circ} \mathrm{UO}_{2} \mathrm{Br}_{2}(\mathrm{c})=-271.84 \pm 0.32$ is obtained from the summation: $\mathrm{UO}_{3}(\mathrm{c}, \gamma)+2 \mathrm{HBr}(\mathrm{aq}) \rightarrow \mathrm{UO}_{2} \mathrm{Br}_{2}(\mathrm{c})+\mathrm{H}_{2} \mathrm{O}(\mathrm{aq}) ; \Delta \mathrm{H}_{5}=7.50 \pm 0.11 \mathrm{kcal} / \mathrm{mol}$ using the differentials, $\Delta \overline{\mathrm{H}}^{\circ} \mathrm{HBr}(\mathrm{aq})=-27.60 \mathrm{kcal} / \mathrm{mol}$ and $\Delta \overline{\mathrm{H}} \mathrm{f}^{\circ} \mathrm{H}_{2} \mathrm{O}(\mathrm{aq})$ $=-68.361 \mathrm{kcal} / \mathrm{mol}$.

For the $\Delta H^{\prime} s$ of hydration:

$$
\begin{aligned}
& \mathrm{UO}_{2} \mathrm{Br}_{2}(\mathrm{c})+\mathrm{H}_{2} \mathrm{O}(1) \rightarrow \mathrm{UO}_{2} \mathrm{Br}_{2} \cdot \mathrm{H}_{2} \mathrm{O}(\mathrm{c}) ; \Delta_{6}=-7.82 \pm 0.18 \mathrm{kcal} / \mathrm{mol} \\
& \mathrm{UO}_{2} \mathrm{Br}_{2}(\mathrm{c})+3 \mathrm{H}_{2} \mathrm{O}(1) \rightarrow \mathrm{UO}_{2} \mathrm{Br}_{2} \cdot 3 \mathrm{H}_{2} \mathrm{O}(\mathrm{c}) ; \Delta \mathrm{H}_{7}=-15.09 \pm 0.22 \mathrm{kcal} / \mathrm{mol}
\end{aligned}
$$


from which $\Delta \mathrm{Hf}^{\circ} \mathrm{UO}_{2} \mathrm{Br}_{2} \cdot \mathrm{H}_{2} \mathrm{O}(\mathrm{c})=-347.97 \pm 0.34 \mathrm{kcal} / \mathrm{mol}$ and $\Delta \mathrm{Hf}^{\circ}$ $\mathrm{UO}_{2} \mathrm{Br}_{2} \cdot 3 \mathrm{H}_{2} \mathrm{O}(\mathrm{c})=-491.88 \pm 0.36 \mathrm{kcal} / \mathrm{mol}$.

The $\Delta \mathrm{H}^{\prime} \mathrm{s}$ of hydration for $\mathrm{UO}_{2} \mathrm{Br}_{2}(\mathrm{c})$ and $\mathrm{UO}_{2} \mathrm{Cl}_{2}(\mathrm{c})$ appear to be essentially the same.

The earlier measurements of Shchukarev et al. (1958a) on $\Delta \mathrm{H}_{\text {soln }}$ $\mathrm{UO}_{2} \mathrm{Cl}_{2}(\mathrm{c})=-25.44 \pm 0.07$ and (1958b) on $\Delta \mathrm{H}_{\text {soln }} \mathrm{UO}_{2} \mathrm{Br}_{2}(\mathrm{c})=-31.23 \pm 0.2$ $\mathrm{kcal} / \mathrm{mol}$ in $2 \% \mathrm{HCl}, 0.5 \% \mathrm{FeCl}_{3}$ aqueous solutions lead to:

$$
\begin{gathered}
\mathrm{UO}_{2} \mathrm{Cl}_{2}(\mathrm{c})+2 \mathrm{HBr}(\mathrm{aq}) \rightarrow \mathrm{UO}_{2} \mathrm{Br}_{2}(\mathrm{c})+2 \mathrm{HCl}(\mathrm{aq}) ; \\
\Delta \mathrm{H}_{8}=5.79 \pm 0.5^{*} \mathrm{kcal} / \mathrm{mol}
\end{gathered}
$$

which, with the differentials for the formation of $\mathrm{HX}\left(100 \mathrm{H}_{2} \mathrm{O}\right), \Delta \overline{\mathrm{H}} f \mathrm{HCl}$ $=-39.489$ and $\Delta \overline{\mathrm{H}} \mathrm{HBr}=-28.689 \mathrm{kcal} / \mathrm{mol}$, results in $\Delta \mathrm{Hf}^{\circ} \mathrm{UO}_{2} \mathrm{Br}_{2}=$ $-269.8 \mathrm{kcal} / \mathrm{mol}$, in poor agreement with the Prins et al. results.

From the Shchukarev et al. (1959b) $\Delta \mathrm{H}_{\text {soln }}$ measurements of the anhydrous $\mathrm{UO}_{2} \mathrm{Br}_{2}(\mathrm{c})$ and the two hydrates in $\mathrm{H}_{2} \mathrm{O}, \Delta \mathrm{H}_{6}=-8.9 \mathrm{kcal} / \mathrm{mol}$ and $\Delta \mathrm{H}_{7}=-11.8 \mathrm{kcal} / \mathrm{mol}$, also in poor agreement with the Prins et al. results.

The Shchukarev et al. (1958a, 1958b, 1959b) measurements on the $\mathrm{UO}_{2} \mathrm{Br}_{2} \cdot \mathrm{nH}_{2} \mathrm{O}$ system are suspect and are rejected for the following reasons:

1. The $\Delta \mathrm{H}_{\text {soln }} \mathrm{FeCl}_{3}$ (c) in a solution of $2 \% \mathrm{HCl}$ by Shchukarev et al. (1958a) has been found to be in error.

2. The $\Delta \mathrm{H}$ 's of hydration of $\mathrm{UO}_{2} \mathrm{Cl}_{2}$ (c) to the two hydrates from Shchukarev et al. (1959b) appear to be incorrect. See $\mathrm{UO}_{2} \mathrm{Cl}_{2} \cdot \mathrm{H}_{2} \mathrm{O}(\mathrm{c})$ and $\mathrm{UO}_{2} \mathrm{Cl}_{2} \cdot 3 \mathrm{H}_{2} \mathrm{O}(\mathrm{c})$.

3. A comparison of the $\Delta \mathrm{H}$ 's of solution of $\mathrm{UO}_{2} \mathrm{Br}_{2}$ in a solution of $2 \% \mathrm{HCl}, 0.5 \% \mathrm{FeCl}_{3}$ (1958b) and in $\mathrm{H}_{2} \mathrm{O}(1)$ (1959b)

\footnotetext{
"See $\mathrm{UO}_{2} \mathrm{Cl}_{2}$ (c) discussion on the "Shchukarev" cycle. 
with those for $\mathrm{UO}_{2} \mathrm{Cl}_{2}(\mathrm{c})$ indicates an inconsistency which may be caused by erroneous measurements on $\mathrm{UO}_{2} \mathrm{Br}_{2}(c)$.

The Prins measurements, in contrast, offer a consistent picture on the behavior of $\mathrm{UO}_{2} \mathrm{Cl}_{2} \cdot \mathrm{nH}_{2} \mathrm{O}(\mathrm{c})$ and $\mathrm{UO}_{2} \mathrm{Br}_{2} \cdot \mathrm{nH}_{2} \mathrm{O}(\mathrm{c})$.

The $\Delta G f^{\circ}$ 's have been calculated from the $\Delta H f^{\circ}$ 's and the $\Delta S f^{\circ}$ 's.

$\underline{\mathrm{UOBr}}{ }_{3}(\mathrm{c})$

See $\mathrm{UOCl}_{3}(\mathrm{c})$

$\underline{\mathrm{UO}_{2}(\mathrm{OH}) \mathrm{Br} \cdot 2 \mathrm{H}_{2} \mathrm{O}(\mathrm{c})}$

Prins et al. (1978) measured the $\Delta H_{\text {soln }}=-6.67 \pm 0.01 \mathrm{kcal} / \mathrm{mol}$ of $\mathrm{UO}_{2}(\mathrm{OH}) \mathrm{Br} \cdot 2 \mathrm{H}_{2} \mathrm{O}(\mathrm{c})$ in $\mathrm{HBr}\left(14.63 \mathrm{H}_{2} \mathrm{O}\right)$. Combining this with their measurement for $\Delta \mathrm{H}_{\text {soln }}$ of $\mathrm{UO}_{3}(c, \gamma)$ in $\mathrm{HBr}\left(14.63 \mathrm{H}_{2} \mathrm{O}\right)=-17.88 \pm 0.05$ one obtains:

$$
\mathrm{UO}_{3}(\mathrm{c}, \gamma)+\mathrm{HBr}(\mathrm{aq})+2 \mathrm{H}_{2} \mathrm{O}(\mathrm{aq}) \rightarrow \mathrm{UO}_{2}(\mathrm{OH}) \mathrm{Br} \cdot 2 \mathrm{H}_{2} \mathrm{O}(\mathrm{c}) ; \Delta \mathrm{H}=-11.2 \mathrm{I} \pm 0.05
$$
and $\Delta \mathrm{Hf}^{\circ}=-468.0_{3} \pm 0.3 \mathrm{kcal} / \mathrm{mol}$.

The differential $\Delta \overline{\mathrm{H}} f$ 's to be used are $\Delta \overline{\mathrm{H} f} \mathrm{HBr}\left(14.63 \mathrm{H}_{2} \mathrm{O}\right)=-27.60$ and $\triangle \overline{\mathrm{H}}$. $\mathrm{H}_{2} \mathrm{O}(\mathrm{aq})=-68.361 \mathrm{kcal} / \mathrm{mol}$. 


\section{$3.108 \mathrm{U}-\mathrm{Br}-\mathrm{Cl}$ Compounds}

$\mathrm{UCl}_{3-\mathrm{x}} \mathrm{Br}(\mathrm{c})(\mathrm{x}=1,2)$ and $\mathrm{UCl}_{4-x} \mathrm{Br}(\mathrm{c})(\mathrm{x}=1,2,3)$

MacWood (1958) reports the $\mathrm{K}^{\prime} \mathrm{s}$ for: (1) the $\mathrm{H}_{2}$ reduction of various $\mathrm{UCl}_{4-\mathrm{x}} \mathrm{Br}(\mathrm{c})$ in the range $650-750 \mathrm{~K}$ from the results of Gregory (1945) and (2) the exchange equilibria with $\operatorname{HBr}(\mathrm{g})$ in the range 600-773 $\mathrm{K}$ from the results of Altman (1944). Examples of these equilibria are:

$$
\text { 1. } \mathrm{UCl}_{4-\mathrm{x}} \mathrm{Br}(\mathrm{c})+1 / 2 \mathrm{H}_{2}(\mathrm{~g}) \rightarrow \mathrm{UCl}_{4-\mathrm{x}^{\mathrm{Br}}} \mathrm{x}-1(\mathrm{c})+\mathrm{HBr}(\mathrm{g})
$$

and

$$
\begin{aligned}
& \mathrm{UCl}_{4-x} \mathrm{Br} x(\mathrm{c})+1 / 2 \mathrm{H}_{2}(\mathrm{~g})-\mathrm{UCl}_{3-\mathrm{x}} \mathrm{Br}(\mathrm{c})+\mathrm{HCl}(\mathrm{g}) \\
& \text { 2. } \mathrm{UCl}_{4-\mathrm{x}} \mathrm{Br} x \\
& \mathrm{Cr}_{\mathrm{x}}(\mathrm{c})+\mathrm{HBr}(\mathrm{g}) \rightarrow \mathrm{UCl}_{3-\mathrm{x}} \mathrm{Br} \mathrm{x}+1
\end{aligned}
$$

These $K^{\prime}$ 's and the $\Delta H^{\prime}$ 's calculated from the $\Delta H f^{\circ}$ 's selected here were used to obtain the $S^{\circ}$ 's for the various III and IV mixed halides. They are to be considered approximate values.

MacWood also reports the measurements of Barkelew on the $\Delta H^{\prime} s$ of solution in a $12 \mathrm{~N} \mathrm{HCl} 10 \% \mathrm{FeCl}_{3}$ solution of the mixed halides (III and IV) as well as $\mathrm{UCl}_{3}(c), \mathrm{UCl}_{4}(\mathrm{c}), \mathrm{UBr}_{3}(\mathrm{c})$, and $\mathrm{UBr}_{4}$ (c) from which the $\Delta H f^{\circ}$ 's can be obtained by summation reactions. Examples follow, as well as the measured $\Delta H^{\prime}$ s of solution. 


$$
\begin{aligned}
& \mathrm{UCl}_{2} \mathrm{Br}(\mathrm{c})+\mathrm{HCl}(\mathrm{aq})-\mathrm{UCl}_{3}(\mathrm{c})+\mathrm{HBr}(\mathrm{aq}) ; \\
& \Delta \mathrm{H}=\Delta \mathrm{H}_{\text {soln }} \quad \mathrm{UCl}_{2} \mathrm{Br}-\Delta \mathrm{H}_{\text {soln }} \quad \mathrm{UCl}_{3}(\mathrm{c})
\end{aligned}
$$

and

$$
\begin{aligned}
& \mathrm{UClBr}_{3}(\mathrm{c})+\mathrm{HBr}(\mathrm{aq}) \rightarrow \mathrm{UBr}_{4}(\mathrm{c})+\mathrm{HCl}(\mathrm{aq}) ; \\
& \Delta \mathrm{H}=\Delta \mathrm{H}_{\text {soln }} \mathrm{UClBr}_{3}(\mathrm{c})-\Delta \mathrm{H}_{\text {soln }} \mathrm{UBr}_{4}(\mathrm{c})
\end{aligned}
$$

$$
\begin{aligned}
& \mathrm{UCl}_{3}(\mathrm{c}) \\
& \mathrm{UCl}_{2} \mathrm{Br}(\mathrm{c}) \\
& \mathrm{UC} \mathrm{Br}_{2}(\mathrm{c}) \\
& \mathrm{UBr}_{3}(\mathrm{c}) \\
& \mathrm{UCl}_{4}(\mathrm{c}) \\
& \mathrm{UCl}_{3} \mathrm{Br}(\mathrm{c}) \\
& \mathrm{UCl}_{2} \mathrm{Br}_{2}(\mathrm{c}) \\
& \mathrm{UClBr}_{3}(\mathrm{c}) \\
& \mathrm{UBr}_{4}(\mathrm{c})
\end{aligned}
$$$$
\begin{gathered}
\Delta \mathrm{H}_{\text {soln }} \mathrm{kcal} / \mathrm{mol} \\
-42.0 \\
-44.2 \\
-48.2 \\
-49.5 \\
-24.1 \\
-25.7 \\
-29.2 \\
-31.8 \\
-33.1
\end{gathered}
$$ 
$\underline{U I_{3}(c)}$

Krestov (1972) has estimated the $C_{p}$ as a function of temperature

$$
\mathrm{C}_{\mathrm{p}}=25.1+5.8 \times 10^{-3} \mathrm{~T} \mathrm{cal} / \mathrm{mol} \cdot \mathrm{K}(298-800 \mathrm{~K})
$$

MacWood (1958) tabulated the decomposition pressure measurements (523-666 K) of MacWoui et a1. (1944) for:

$$
U I_{4}(c) \rightarrow U I_{3}(c)+I / 2 I_{2}(g)
$$

From the values for $\Delta H f^{\circ} \mathrm{UI}_{3}(\mathrm{c})$ listed below, $\Delta H f^{\circ}=-111.7 \pm 1.0$ kcal is selected. The resultant $\Delta H^{\circ}{ }_{1}=19.7 \pm 0.5 \mathrm{kcal} / \mathrm{mol}$ is used in combination with the above pressure measurements and $\Delta\left(\mathrm{H}-\mathrm{H}_{298}\right) \mathrm{T}$ and $\Delta\left(S-S_{298}\right)_{T}$ to obtain $\Delta S_{1}=21.8 \pm 1.0 \quad \mathrm{cal} / \mathrm{mol} \cdot \mathrm{K}$ and $\Delta\left(\mathrm{S}^{\circ} \mathrm{UI}_{4}(\mathrm{c})-\mathrm{S}^{\circ} \mathrm{UI} \mathrm{I}_{3}(\mathrm{c})\right)$ $=10 \mathrm{cal} / \mathrm{mol} \cdot \mathrm{K} . \mathrm{S}^{\circ} \mathrm{UI}_{3}(\mathrm{c})=53 \pm 2$ appears reasonable in comparison with the measured $S^{\circ} \mathrm{UCl}_{3}(\mathrm{c})$ and $\Delta S^{\circ}(\mathrm{Cl}-\mathrm{I})$. This value for $\mathrm{S}^{\circ} \mathrm{UI}_{3}(\mathrm{c})$ in conjunction with the estimated $C_{p}$ equation completes the tabulated thermal functions.

The second law value for $\Delta \mathrm{H}^{\circ}{ }_{1}$ from the above decomposition pressure measurements is $18.5 \pm 1.0 \mathrm{kcal} / \mathrm{mol}$ which results in $\Delta H f^{\circ}=$ $-113.0 \pm 1.2 \mathrm{kcal} / \mathrm{mol}$.

MacWood (1958) reporting on the measurements of Barkelew (1946) cites the $\Delta H^{\prime}$ 's reaction of $U_{3}(c)=-56.5$ and $U I_{4}(c)=-44.2 \mathrm{kcal} / \mathrm{mol}$, respectively, with a solvent of $12 \mathrm{~N}$ HCl saturated with $I_{2}(c)$. In these final solutions the uranium is considered to be in (IV) state. Then for the relationship:

$$
\mathrm{UI}_{4}(\mathrm{c})-\mathrm{UI}_{3}(\mathrm{c})+1 / 2 \mathrm{I}_{2}(\mathrm{c}) ; \Delta \mathrm{H}_{2}=12.3 \pm 0.6 \mathrm{kcal} / \mathrm{mol}
$$

and $\Delta H f^{\circ}=-111.7 \pm 1.0 \mathrm{kcal} / \mathrm{mol}$. 
Tveekrem and Chandrasekharaiah (1968) from cell measurements obtained $\Delta G_{643 \mathrm{~K}}^{\circ}=-98.8 \pm 0.4 \mathrm{kcal} / \mathrm{mol}$ for:

$$
U(c)+3 / 2 I_{2}(g) \rightarrow U I_{3}(c)
$$

The third law $\Delta H^{\circ}=-131.5 \pm 1.0$ and $\Delta \mathrm{Hf}^{\circ}=-110.2 \pm 1.0 \mathrm{kcal} / \mathrm{mol}$.

The $\Delta S f^{\circ}=-0.6 \mathrm{cal} / \mathrm{mol} \cdot \mathrm{K}$ results in $\Delta G f^{\circ}=-111.5 \pm 1.2 \mathrm{kcal} / \mathrm{mol}$. $\mathrm{UI}_{4}(\mathrm{c})$

The $S^{\circ}$ has been estimated as $63 \pm 2 \mathrm{cal} / \mathrm{mol}$ based on a comparison of the differences in measured entropies of chlorides and iodides for the polyvalent halides.

Popov et a1. (1959a) have measured the $C_{p}$ of $U I_{4}(c)$ and (1) from $373 \mathrm{~K}$ to $873 \mathrm{~K}$.

Rand and Kubaschewski (1963) used these measurements to obtain for $\mathrm{UI}_{4}(\mathrm{c})$ :

$$
C_{p}=34.8+2.38 \times 10^{-3} \mathrm{~T}-4.72 \times 10^{5} \mathrm{~T}^{-2} \mathrm{cal} / \mathrm{mol} \cdot \mathrm{K} \quad(380-720 \mathrm{~K})
$$

The results of Popov et al., for the phase changes have been accepted. (See the discussion of the vapor pressure data for $\mathrm{UI}_{4}$ (c) and (1) under $\left.\mathrm{UI}_{4}(\mathrm{~g})_{.}\right)$The total $\triangle \mathrm{H}$ for the phase changes of $\mathrm{UI}_{4}(\mathrm{c})$ to $\mathrm{UI}_{4}(1)$ (m.p. $\approx 779 \mathrm{~K}$ ) is $9.2 \mathrm{kcal} / \mathrm{mol}$. For $\mathrm{UI}_{4}(1): \mathrm{C}_{\mathrm{p}}=39.6$ $\mathrm{cal} / \mathrm{mol} \cdot \mathrm{K} \quad(820-870 \mathrm{~K})$.

The selected $\mathrm{C}_{\mathrm{P}}{ }^{\circ}$ at $298 \mathrm{~K}$ is obtained from the extrapolation of the measurements below $473 \mathrm{~K}$. Smoothed tabulated functions are given here incorporating the estimated $\mathrm{S}^{\circ} 298^{\circ}$

The measurements of Fuger and Brown (1973) on the enthalpies of solution of $\mathrm{UI}_{4}(\mathrm{c})(-69.29 \pm 0.3 \mathrm{kcal} / \mathrm{mol})$ and $\mathrm{UCl}_{4}(\mathrm{c})(-54.46 \pm 0.23$ 
$\mathrm{kcal} / \mathrm{mol})$ in $1 \mathrm{M} \mathrm{HCl}$, i.e., $\mathrm{HCl}\left(54.4 \mathrm{H}_{2} \mathrm{O}\right)$ lead to:

$$
\mathrm{UI}_{4}(\mathrm{c})+4 \mathrm{HCI}(\mathrm{aq}) \rightarrow \mathrm{UCl}_{4}(\mathrm{c})+4 \mathrm{HI}(\mathrm{aq}) ; \Delta \mathrm{H}_{1}=-14.83 \pm 0.38 \mathrm{kcal} / \mathrm{mol}
$$

With the assumption that the differential $\Delta \overline{\mathrm{H}} f \mathrm{HI}(\mathrm{aq})$ in $\mathrm{HCl}$ is the same as in an HI solution $=13.265 \mathrm{kcal} / \mathrm{mol}$ and using $\Delta \overline{\mathrm{H}} f \mathrm{HCl}=$ $-39.284, \Delta \mathrm{Hf}^{\circ}=-124.55 \pm 0.07 \mathrm{kcal} / \mathrm{mol}$.

In addition, from their measurements in $6 \mathrm{M} \mathrm{HCl}$ (i.e. $\mathrm{HCl}\left(8 \cdot 13 \mathrm{H}_{2} \mathrm{O}\right)$ ) $\left(8.13 \mathrm{H}_{2} \mathrm{O}\right)$ of $\mathrm{UI}_{4}(\mathrm{c})=-57.41 \pm 0.07$ and $\mathrm{UBr}_{4}(\mathrm{c})=-49.17 \pm 0.20$, there is:

$$
\mathrm{UI}_{4}(\mathrm{c})+4 \mathrm{HBr}(\mathrm{aq}) \rightarrow \mathrm{UBr}_{4}(\mathrm{c})+4 \mathrm{HI}(\mathrm{aq}) ; \Delta \mathrm{H}_{2}=-8.24 \pm 0.21
$$

With the same assumption, i.e., that the differentials, $\Delta \bar{H} f$ 's of $\mathrm{HBr}=-26.103$ and $\mathrm{HI}=-11.202$ in $\mathrm{HCl}$ are equivalent to the differentials in their own respective solutions, $\Delta \mathrm{Hf}^{\circ}=-123.51 \pm 0.7 \mathrm{kcal} / \mathrm{mol}$. The average $\Delta \mathrm{Hf}^{\circ}=-124.0 \pm 0.7 \mathrm{kcal} / \mathrm{mol}$ is accepted.

The calculated $\Delta S f^{\circ}=-4.52 \pm 2.0 \mathrm{cal} / \mathrm{mol} \cdot \mathrm{K}$ and the $\Delta \mathrm{Hf}^{\circ}=-124.0$ \pm 0.7 results in $\Delta G f^{\circ}=-122.7 \pm 0.9 \mathrm{kcal} / \mathrm{mol}$. 
$\underline{\mathrm{UI}} \mathrm{I}_{4}(\mathrm{~g})$

The vapor pressure of $\mathrm{UI}_{4}(\mathrm{c})$ has been measured by Thompson and Schelberg (as given by Katz and Rabinowitch (1951)); 573-683 K; effusion method and that of $\mathrm{UI}_{4}(1)$ by Gregory (1946); 823-923 K; boiling point measurements against a known pressure of $I_{2}(g)$ to prevent decomposition of $\mathrm{UI}_{4}$. These have been reviewed by Rand and Kubaschewski (1963); however, the calculated values obtained for $\Delta \mathrm{H}_{\text {fusion }}(16.9 \mathrm{kcal} / \mathrm{mol})$ and $\Delta \mathrm{S}_{\text {fusion }}(21.6 \mathrm{cal} / \mathrm{mol} \cdot \mathrm{K})$ at the melting point, $779 \pm 3 \mathrm{~K}$, (Gregory (1946)) are unreasonable.

Popov et al.'s (1959a) $\mathrm{C}_{\mathrm{p}}$ measurements on $\mathrm{UI}_{4}(\mathrm{c})$ and (1) indicate a total $\Delta H=9.2 \mathrm{kcal} / \mathrm{mol}$ and $\Delta S=12.1 \mathrm{cal} / \mathrm{mol}{ }^{\circ} \mathrm{K}$ for the phase changes $\left(\Delta \mathrm{H}_{\text {trans }}=3.53 \pm 0.1 \mathrm{kcal} / \mathrm{mol}\right.$ at $\sim 723 \mathrm{~K}, \Delta \mathrm{H}_{\text {fusion }}=5.64 \pm 0.2$ at the melting point) which are reasonable although possibly low. This indicates that either one or both sets of vapor pressure measurements are in error.

If the $\mathrm{UI}_{4}(\mathrm{c})$ measurements are correct, $\mathrm{S}^{\circ} \mathrm{UI}_{4}(\mathrm{~g}) \approx 125 \mathrm{cal} / \mathrm{mol} \cdot \mathrm{K}$ at $298 \mathrm{~K}$. If the $\mathrm{UI}_{4}(1)$ measurements are correct, then Gregory's (1946) measurements can be described (with $\Delta \mathrm{C}_{\mathrm{p}}=-15 \mathrm{cal} / \mathrm{mol} \cdot \mathrm{K}$ ) by:

$$
\begin{array}{cl}
\mathrm{UI}_{4}(1) \rightarrow \mathrm{UI}_{4}(\mathrm{~g}) & \text { (1) } \\
\Delta \mathrm{G}_{1}=47,770-150.67 \mathrm{~T}+34.54 \mathrm{~T} \log \mathrm{T} \mathrm{cal} / \mathrm{mol} ; & (792-1000 \mathrm{~K})
\end{array}
$$

and at $900 \mathrm{~K}$ :

$$
\begin{aligned}
\Delta \mathrm{H}_{1} & =34.3 \mathrm{kcal} / \mathrm{mol} \\
\Delta G_{1} & =4.00 \mathrm{kcal} / \mathrm{mol} \\
\Delta S_{1} & =33.7 \mathrm{cal} / \mathrm{mol} \cdot \mathrm{K}
\end{aligned}
$$

Using $\Delta\left(\mathrm{S}-\mathrm{S}_{298}\right)_{900}$ from the $\mathrm{ThI}_{4}$ system $=-21.3 \mathrm{cal} / \mathrm{mol} \cdot \mathrm{K}$ (Wagman et al. (1977)), results in $\Delta S^{\circ}{ }_{1}$ at $298 \mathrm{~K}=55 \mathrm{cal} / \mathrm{mol} \cdot \mathrm{K}$ and $\mathrm{S}^{\circ} \mathrm{UI}_{4}(\mathrm{~g})$ $=118 \mathrm{cal} / \mathrm{mol} \cdot \mathrm{K}$, which appears more reasonable, in a correlation of 
the $\mathrm{S}^{\circ}$ 's for the Th-U halides, than $125 \mathrm{cal} / \mathrm{mol} \cdot \mathrm{K}$. For the vaporization, the expression for $\Delta G_{1}$ is accepted. The extrapolated boiling point is $1020 \mathrm{~K}$ with $\Delta S_{\text {vap }}=31.9 \mathrm{cal} / \mathrm{mol} \cdot \mathrm{K}$. For the sublimation,

$$
\mathrm{UI}_{4}(\mathrm{c}) \rightarrow \mathrm{UI}_{4}(\mathrm{~g}),
$$

with $\Delta \mathrm{H}_{2}=34.3 \mathrm{kcal} / \mathrm{mol}$ at $900 \mathrm{~K}$ and the comparable $\Delta\left(\mathrm{H}-\mathrm{H}_{298}\right)_{900}=$ $-16.00 \mathrm{kcal} / \mathrm{mol}$ from the $\mathrm{ThI}_{4}$ system (Wagman et al. (1977)) one obtains at $298 \mathrm{~K}$ :

$$
\begin{aligned}
\Delta \mathrm{H}^{\circ}{ }_{2} & =50.3 \mathrm{kcal} / \mathrm{mol} \\
\Delta S^{\circ}{ }_{2} & =55.0 \mathrm{cal} / \mathrm{mol} \cdot \mathrm{K} \\
\Delta G^{\circ}{ }_{2} & =33.9 \mathrm{kcal} / \mathrm{mol}
\end{aligned}
$$

The tabulated values are obtained from these values.

An approximate equation then for this process is:

$$
\Delta G_{2}=52,400-101.9 \mathrm{~T}+16.1 \mathrm{~T} \log \mathrm{T} \mathrm{cal} / \mathrm{mol} ;(550-700 \mathrm{~K})
$$




\section{$3.110 \quad \mathrm{U}-\mathrm{I}-\mathrm{C} 1-\mathrm{Br}$ Compounds}

$\mathrm{UC}_{3} I(c)$ and $\mathrm{UBr}_{3} I(c)$

MacWood (1958), reporting on the measurements of Barkelew, cites the reactions of $\mathrm{UCl}_{3} \mathrm{I}(\mathrm{c})(\Delta \mathrm{H}=-28.0 \mathrm{kcal} / \mathrm{mol}), \mathrm{UCl}_{3}(\mathrm{c})(\Delta \mathrm{H}=-35.7$ $\mathrm{kcal} / \mathrm{mol})$ and $\mathrm{UBr}_{3} \mathrm{I}(\mathrm{c})(\Delta \mathrm{H}=-36.7 \mathrm{kcal} / \mathrm{mol})$ with a solvent of $12 \mathrm{~N}$ $\mathrm{HCl}$ saturated with $I_{2}(c)$ at $273 \mathrm{~K}$. Since the resultant final onlutions are considered to contain the $U(I V)$ species, a summation results in:

$$
\mathrm{UCl}_{3}(\mathrm{c})+1 / 2 \mathrm{I}_{2}(\mathrm{c})-\mathrm{UCl}_{3} \mathrm{I}(\mathrm{c}) ; \Delta \mathrm{H}_{1}^{*}=-7.7 \mathrm{kcal} / \mathrm{mol}
$$

The calculated $\Delta \mathrm{Hf}^{\circ}=-214.7 \pm 2.0 \mathrm{kcal} / \mathrm{mol}$.

$$
\mathrm{UCl}_{3} \mathrm{I}(\mathrm{c})+3 \mathrm{HBr}(\mathrm{aq})-\mathrm{UBr}_{3} \mathrm{I}(\mathrm{c})+3 \mathrm{HCl}(\mathrm{aq}) ; \Delta \mathrm{H}_{2}{ }^{*}=+8.7 \mathrm{kcal} / \mathrm{mol}
$$

With $\triangle \overline{\mathrm{H} f} \mathrm{HCl}(\mathrm{aq})=-32.7 \mathrm{kcal} / \mathrm{mol}$ and $\Delta \overline{\mathrm{H} f} \mathrm{HBr}(\mathrm{aq})=-22.0 \mathrm{kca} 1 / \mathrm{mol}$ which pertain to the particular solutions used by Barkelew and incorporates the experimental components measured by Barkelew, $\Delta H f^{\circ}$ $\mathrm{UBr}_{3} I(\mathrm{c})=-173.9 \pm 2.0 \mathrm{kcal} / \mathrm{mol}$.

These values are accepted.

MacWood (1958) cites the measurements of Davidson et al. (1945) for the $I_{2}$ pressure (effusion method) over $\mathrm{UCl}_{3} I(c)$ and $\mathrm{UBr}_{3} I(c)$.

$$
\begin{gathered}
\mathrm{UCl}_{3} \mathrm{I}(\mathrm{c})-\mathrm{UCl}_{3}(\mathrm{c})+1 / 2 \mathrm{I}_{2}(\mathrm{~g}) \\
(472-575 \mathrm{~K}) \\
\mathrm{UBr}_{3} \mathrm{I}(\mathrm{c}) \rightarrow \mathrm{UBr}_{3}(\mathrm{c})+1 / 2 \mathrm{I}_{2}(\mathrm{~g}) \\
(551-655 \mathrm{~K})
\end{gathered}
$$

With the accepted $\Delta \mathrm{Hf}^{\circ} \mathrm{UCl}_{3} \mathrm{I}(\mathrm{c}), \Delta \mathrm{H}_{3}=15.16 \mathrm{kcal} / \mathrm{mol}$ at $298 \mathrm{~K}$ and with a $\Delta_{p}=-2$ cal/mol $\cdot K$ the equilibrium $K$ 's can be fit to:

$$
\Delta G_{3}^{\circ}=15,760+4.51 \mathrm{Tlog} \mathrm{T}-31.5 \mathrm{~T} \mathrm{cal} / \mathrm{mol}
$$

The $\triangle C_{p}$ for this is negligible. 
This results in $\Delta G_{3}^{\circ}=9.8 \mathrm{kcal} / \mathrm{mol}$ and $\Delta S_{3}^{\circ}=18 \mathrm{cal} / \mathrm{mol} \cdot \mathrm{K}$, from which the tabulated values for $\Delta G f^{\circ}$ and $S^{\circ}$ for $U C I_{3} I(c)$ are obtained. Similarly $\Delta \mathrm{H}_{4}^{\circ}=14.0 \mathrm{kcal} / \mathrm{mol}$ at $298 \mathrm{~K}$. Here, however, a similar treatment of the $K^{\prime} s$ results in a $\Delta S^{\circ}{ }_{4} \approx 13 \mathrm{cal} / \mathrm{mol}$ which is too low (i.e., the calculated $\mathrm{S}^{\circ} \mathrm{UBr}_{3} I(\mathrm{c})=64 \mathrm{cal} / \mathrm{mol} \cdot \mathrm{K}$, too high a value); no improvement is made by adjusting the $\Delta_{p}$. In the absence of more information on this system, no recommendation is made for $\mathrm{S}^{\circ}$ or $\triangle G f^{\circ}$ for $\mathrm{UBr}_{3} I(c)$. 


\subsection{U-X Compounds with $\mathrm{N}$}

$3.201 \quad \mathrm{U}-\mathrm{NH}_{4}-\mathrm{F}-\mathrm{O}$ Compounds

$\left(\mathrm{NH}_{4}\right)_{3} \mathrm{UO}_{2} \mathrm{~F}_{5}(\mathrm{c})$ and $\mathrm{NH}_{4}\left[\left(\mathrm{UO}_{2}\right)_{2} \mathrm{~F}_{5}\right](\mathrm{c})$

Mukhametshina et al. (1974b) from a series of reactions in 2M

HC1 reported:

$$
3 \mathrm{NH}_{4} \mathrm{~F}(\mathrm{c})+\mathrm{UO}_{2} \mathrm{~F}_{2}(\mathrm{c}) \rightarrow\left(\mathrm{NH}_{4}\right)_{3} \mathrm{UO}_{2} \mathrm{~F}_{5}(\mathrm{c}) ; \Delta \mathrm{H}_{1}=-17.74 \pm 0.27 \mathrm{kca} 1 / \mathrm{mol}
$$

which, using $\Delta \mathrm{Hf}^{\circ} \mathrm{NH}_{4} \mathrm{~F}(\mathrm{c})^{*}=-111.7 \pm 0.2 \mathrm{kcal} / \mathrm{mol}$, results in $\Delta \mathrm{Hf}^{\circ}=$ $-748.0 \pm 0.7 \mathrm{kcal} / \mathrm{mol}$.

Similarly, Suponitskii et al. (1974) obtained:

$$
\mathrm{NH}_{4}(\mathrm{c})+2 \mathrm{UO}_{2} \mathrm{~F}_{2}(\mathrm{c}) \rightarrow \mathrm{NH}_{4}\left(\mathrm{UO}_{2}\right)_{2} \mathrm{~F}_{5}(\mathrm{c}) ; \Delta \mathrm{H}_{2}=-12.99 \pm 0.50 \mathrm{kcal} / \mathrm{mol}
$$

which results in $\Delta \mathrm{Hf}^{\circ}=-915.1 \pm 0.8 \mathrm{kcal} / \mathrm{mol}$.

The above values are accepted, in preference to those which can be derived from the decomposition pressure measurements of Sudarikov et al. (1970) on $\left(\mathrm{NH}_{4}\right)_{3} \mathrm{UO}_{2} \mathrm{~F}_{5}(\mathrm{c})$, the ammonium dioxopentafluorouranate (VI) and the intermediate compound, $\mathrm{NH}_{4}\left[\left(\mathrm{UO}_{2}\right)_{2}{ }_{2}{ }_{5}\right](\mathrm{c})$, the ammonium tetraoxopentafluordiuranate (VI).

*. This is compatible with the coDATA selections. It is derived from the following:

(1) Higgins and Westrum (1961) measured the $\Delta \mathrm{H}^{\prime} \mathrm{s}$ soln $\mathrm{NH}_{3}(\mathrm{~g})=$ $-42.53 \pm 0.06$ and $\mathrm{NH}_{4} \mathrm{~F}(\mathrm{c})=-14.31 \pm 0.03 \mathrm{kcal} / \mathrm{mol}$ in $\mathrm{HF}(1)$ so that .

$\mathrm{NH}_{3}(\mathrm{~g})+\mathrm{HF}(\mathrm{l}) \rightarrow \mathrm{NH}_{4} \mathrm{~F}(\mathrm{c}) ; \Delta \mathrm{H}=-28.22 \pm 0.07 \mathrm{kcal} / \mathrm{mol}$

From Johnson et a 1. (1973) $\Delta \mathrm{Hf}^{\circ} \mathrm{HF}(1)=-72.55 \pm 0.06 \mathrm{kcal} / \mathrm{mol}$, so that $\triangle H f^{\circ} \mathrm{NH}_{4} \mathrm{~F}(\mathrm{c})=-111.75 \pm 0.06$;

(2) Armstrong et al. (1959) obtained:

$\mathrm{NF}_{3}(\mathrm{~g})+4 \mathrm{NH}_{3}(\mathrm{~g}) \rightarrow 3 \mathrm{NH}_{4} \mathrm{~F}(\mathrm{c})+\mathrm{N}_{2}(\mathrm{~g}) ; \Delta \mathrm{H}=-259.5 \pm 1.0 \mathrm{kcal} / \mathrm{mol}$ which using $\Delta \mathrm{Hf}^{\circ} \mathrm{NF}_{3}(\mathrm{~g})=-31.60 \pm 0.1 \mathrm{kcal} / \mathrm{moi}$ (evaluated from sources in JANAF (1971)) results in $\triangle \mathrm{Hf}^{\circ} \mathrm{NH}_{4} \mathrm{~F}(\mathrm{c})=-111.67 \pm 0.4 \mathrm{kcal} / \mathrm{mol}$. 
The decomposition pressures are described by:

$$
\begin{gathered}
\left(\mathrm{NH}_{4}\right)_{3} \mathrm{UO}_{2} \mathrm{~F}_{5}(\mathrm{c})-0.5 \mathrm{NH}_{4}\left[\left(\mathrm{UO}_{2}\right)_{2} \mathrm{~F}_{5}\right](\mathrm{c})+2.5 \mathrm{NH}_{3}(\mathrm{~g})+2.5 \mathrm{HF}(\mathrm{g}) \\
\log \mathrm{P}(\mathrm{atm})=8.01-4.468 \times 10^{3} / \mathrm{T}(516-538 \mathrm{~K}) \\
\Delta G^{\circ}{ }_{3}=102.3-176.4 \times 10^{-3} \mathrm{~T} \mathrm{kcal} / \mathrm{mol} \mathrm{U}
\end{gathered}
$$

and

$$
\begin{gathered}
0.5 \mathrm{NH}_{4}\left[\left(\mathrm{UO}_{2}\right)_{2} \mathrm{~F}_{5}\right](\mathrm{c}) \rightarrow \mathrm{UO}_{2} \mathrm{~F}_{2}(\mathrm{c})+0.5 \mathrm{NH}_{3}(\mathrm{~g})+0.5 \mathrm{HF}(\mathrm{g}) \\
\log \mathrm{P}(\mathrm{atm})=6.927-4.878 \times 10^{3} / \mathrm{T}(647-703 \mathrm{~K}) \\
\Delta G_{4}^{\circ}=22.3-30.3 \times 10^{-3} \mathrm{~T} \mathrm{kcal} / \mathrm{mol} \mathrm{U}
\end{gathered}
$$

Assuming the $\Delta_{p}$ 's for these decompositions are negligible and with the use of:

$$
\mathrm{NH}_{4} \mathrm{~F}(\mathrm{c}) \rightarrow \mathrm{NH}_{3}(\mathrm{~g})+\mathrm{HF}(\mathrm{g}) ; \Delta \mathrm{H}_{5}=35.40 \pm 0.20 \mathrm{kcal} / \mathrm{mol}
$$

we obtain $\Delta \mathrm{H}_{1}=-\Delta \mathrm{H}_{3}-\Delta \mathrm{H}_{4}+3 \Delta \mathrm{H}_{5}=-18.4 \pm 6.0 \mathrm{kcal} / \mathrm{mol}$ and $\Delta \mathrm{H}_{2}=$ $-2 \Delta \mathrm{H}_{4}+\Delta \mathrm{H}_{5}=-9.2 \pm 2.0 \mathrm{kcal} / \mathrm{mol}$.

Since the temperature range for these decomposition measurements is short, these results are not unreasonable. If the measured pressures are used with the preferred values for $\Delta H f^{\circ}$, the following relations result for the decompositions:

$$
\begin{aligned}
& \Delta G_{3}=99,700-171.6 \mathrm{~T} \mathrm{cal} / \mathrm{mol} \\
& \log \mathrm{P}(\mathrm{atm})=7.80-4.36 \times 10^{3} / \mathrm{T}
\end{aligned}
$$

and

$$
\begin{gathered}
\Delta G_{4}=24,200-33.1 \mathrm{~T} \mathrm{cal} / \mathrm{mol} \\
\log P(\mathrm{~atm})=7.53-5.29 \times 10^{3} / \mathrm{T}
\end{gathered}
$$

Approximate $S^{\circ}$ values of $86 \pm 5$ and $90 \pm 5 \mathrm{cal} / \mathrm{mol} \cdot \mathrm{K}$ are calculated for $\mathrm{NH}_{4}\left(\mathrm{UO}_{2}\right)_{2} \mathrm{~F}_{5}(\mathrm{c})$ and $\left(\mathrm{NH}_{4}\right)_{3} \mathrm{UO}_{2} \mathrm{~F}_{5}(\mathrm{c})$, respectively. 
$\underline{\mathrm{NH}_{4}\left[\left(\mathrm{UO}_{2}\right)_{2} \mathrm{~F}_{5}\right] \cdot 3 \mathrm{H}_{2} \mathrm{O}(\mathrm{c}) \text { and } \mathrm{NH}_{4}\left[\left(\mathrm{UO}_{2}\right)_{2} \mathrm{~F}_{5}\right] \cdot 4 \mathrm{H}_{2} \mathrm{O}(\mathrm{c})}$

Tsvetkov et al (1971) measured the vapor pressure of the hexagonal tetrahydrate $\mathrm{NH}_{4}\left[\left(\mathrm{UO}_{2}\right)_{2} \mathrm{~F}_{5}\right] \cdot 4 \mathrm{H}_{2} \mathrm{O}(\mathrm{c})$ and the orthorhombic trihydrate. They reported the following:

$$
\begin{aligned}
& \mathrm{NH}_{4}\left[\left(\mathrm{UO}_{2}\right){ }_{2} \mathrm{~F}_{5}\right] \cdot 3 \mathrm{H}_{2} \mathrm{O}(\mathrm{c}) \rightarrow \mathrm{NH}_{4}\left[\left(\mathrm{UO}_{2}\right)_{2} \mathrm{~F}_{5}\right](\mathrm{c})+3 \mathrm{H}_{2} \mathrm{O}(\mathrm{g}) \\
& \log \mathrm{P}(\mathrm{atm})=7.02 \pm 0.54-2,684 \pm 181 / \mathrm{T}(303-372 \mathrm{~K})
\end{aligned}
$$

and

$$
\begin{gathered}
\mathrm{NH}_{4}\left[\left(\mathrm{UO}_{2}\right)_{2} \mathrm{~F}_{5}\right] \cdot 4 \mathrm{H}_{2} \mathrm{O}(\mathrm{c}) \rightarrow \mathrm{NH}_{4}\left[\left(\mathrm{UO}_{2}\right)_{2} \mathrm{~F}_{5}\right] \cdot 3 \mathrm{H}_{2} \mathrm{O}(\mathrm{c})+\mathrm{H}_{2} \mathrm{O}(\mathrm{g}) \\
\log \mathrm{P}(\mathrm{atm})=6.84 \pm 1.10-2,533 \pm 350 / \mathrm{T}(303-338 \mathrm{~K})
\end{gathered}
$$

These vapor pressure equations lead to the following:

$$
\begin{array}{ll}
\Delta \mathrm{H}^{\circ}=12.3 \pm 0.8 \mathrm{kcal} / \mathrm{mol} \mathrm{H} \mathrm{O}(\mathrm{g}) & 11.6 \pm 1.6 \mathrm{kcal} / \mathrm{mol} \mathrm{H}_{2} \mathrm{O}(\mathrm{g}) \\
\Delta \mathrm{S}^{\circ}=32.2 \pm 2.5 \mathrm{cal} / \mathrm{mol} \mathrm{H} \mathrm{H}_{2} \mathrm{O}(\mathrm{g}) & 31.3 \pm 4.5 \mathrm{cal} / \mathrm{mol} \mathrm{H}_{2} \mathrm{O}(\mathrm{g}) \\
\Delta G^{\circ}=2.7 \pm 1.0 \mathrm{kcal} / \mathrm{mol} \mathrm{H} \mathrm{H}_{2} \mathrm{O}(\mathrm{g}) & 2.3 \pm 1.6 \mathrm{kcal} / \mathrm{mol} \mathrm{H} \mathrm{O}_{2} \mathrm{O}(\mathrm{g})
\end{array}
$$

In both cases $\Delta S^{\circ}$ appears low. Normally a $\Delta S$ of $35-36 \mathrm{cal} / \mathrm{mol}$ $\mathrm{H}_{2} \mathrm{O}(\mathrm{g})$ would be expected. The $\Delta \mathrm{G}^{\circ}$ 's have been accepted and have been used with the estimated $\Delta S^{\circ}=35 \pm 2 \mathrm{cal} / \mathrm{mol} \mathrm{H}_{2} \mathrm{O}(\mathrm{g})$ to obtain $\Delta \mathrm{H}^{\circ}{ }_{1}=$ $13.1 \pm 1.3 \mathrm{kca} 1 / \mathrm{mol} \mathrm{H}_{2} \mathrm{O}(\mathrm{g})$ and $\Delta \mathrm{H}_{2}^{\circ}=12.7 \pm 1.7 \mathrm{kca} / \mathrm{mol} \mathrm{H} \mathrm{H}_{2} \mathrm{O}(\mathrm{g})$. These lead to the following approximate formation properties:

$$
\text { trihydrate }
$$

$\triangle H f^{\circ}$

$\triangle G f$

$\mathrm{S}$
$-1128$

$-1015$

$116 \pm 10$ tetrahydrate

$-1198 \mathrm{kca} 1 / \mathrm{mol}$

$-1072 \mathrm{kcal} / \mathrm{mol}$

$126 \pm 10 \mathrm{ca} 1 / \mathrm{mol} \cdot \mathrm{K}$ 
3.300 U-X Compounds and the Alka li Metals, M (M=Li, Na, K, Rb, or Cs)

$3.301 \quad U-F-M$ Compounds

$\mathrm{MUF}_{6}(\mathrm{c})(\mathrm{M}=\mathrm{Na}(\xi), \mathrm{K}, \mathrm{Rb}$, and $\mathrm{Cs})$

Kudryashov et al. (1978a) measured the enthalpy of oxidation of the alkali metal uranium $(V)$ hexafluorides, $M_{6}(c)$ in aqueous solutions containing $0.8 \% \mathrm{H}_{2} \mathrm{O}_{2}$ (i.e. $\ddot{\mathrm{r}}_{2} \mathrm{O}_{2}\left(250 \mathrm{H}_{2} \mathrm{O}\right)$ ), $1.72 \% \mathrm{~K}_{2} \mathrm{CO}_{3}+2.5 \% \mathrm{KOH}$ (i.e. $\mathrm{KOH}\left(12 \mathrm{OH}_{2} 0\right)$ ), and the reaction of $\mathrm{UCl}_{4}(\mathrm{c})$ in the same media $\left(\mathrm{HH}_{2}=-175.4 \pm 0.3 \mathrm{kcal} / \mathrm{mol}\right)$.

$$
\begin{aligned}
& \mathrm{MUF}_{6}(\mathrm{c})+\left[3 \mathrm{~K}_{2} \mathrm{CO}_{3}+4 \mathrm{KOH}+1 / 2 \mathrm{H}_{2} \mathrm{O}_{2}\right](\mathrm{aq}) \rightarrow {\left[\mathrm{K}_{4} \mathrm{UO}_{2}\left(\mathrm{CO}_{3}\right)_{3}+6 \mathrm{KF}\right.} \\
&+\left.\mathrm{MOH}+2 \mathrm{H}_{2} \mathrm{O}\right](\mathrm{aq}) ; \Delta \mathrm{H}_{1} \\
& \mathrm{UCl}_{4}(\mathrm{c})+\left[3 \mathrm{~K}_{2} \mathrm{CO}_{3}+2 \mathrm{KOH}+\mathrm{H}_{2} \mathrm{O}_{2}\right](\mathrm{aq}) \rightarrow\left[\mathrm{K}_{4} \mathrm{UO}_{2}\left(\mathrm{CO}_{3}\right)_{3}+4 \mathrm{KCl}\right. \\
&\left.+2 \mathrm{H}_{2} \mathrm{O}\right](\mathrm{aq}) ; \Delta \mathrm{H}_{2}
\end{aligned}
$$

With their measured $\Delta H_{\text {soln }} \mathrm{KCl}(\mathrm{c})(3.96 \pm 0.01 \mathrm{kcal} / \mathrm{mol})$ and their $\Delta H^{\prime} \mathrm{s}$ of solution MF(c) tabulated below, the following composite is obtained from which the tabulated $\Delta H^{\circ}{ }^{\prime}$ 's are derived:

\begin{tabular}{|c|c|c|c|}
\hline $\mathrm{MUF}_{6}$ & $\frac{\Delta \mathrm{H}_{1}}{\mathrm{kca} 1}$ & $\begin{array}{c}\Delta H_{\mathrm{soln}} \mathrm{MF}(\mathrm{c}) \\
\mathrm{kca} 1 / \mathrm{mol}\end{array}$ & $\mathrm{\triangle H}_{3}$ \\
\hline $\mathrm{Na}(\hat{\Sigma})$ & $-117.0 \pm 0.3$ & $+0.05 \pm 0.01$ & $-94.59 \pm 0.6$ \\
\hline K & $-114.1 \pm 0.1$ & $-4.08 \pm 0.01$ & $-101.62 \pm 0.5$ \\
\hline $\mathrm{Rb}$ & $-111.8 \pm 0.8$ & $-6.34 \pm 0.10$ & $-106.18 \pm 0.7$ \\
\hline Cs & $-109.6 \pm 0.5$ & $-8.77 \pm 0.06$ & $-110.81 \pm 0.7$ \\
\hline
\end{tabular}

$$
\mathrm{UCl}_{4}(\mathrm{c})+0.5 \mathrm{H}_{2} \mathrm{O}_{2}(\mathrm{aq}) *+\mathrm{MF}(\mathrm{c})+5 \mathrm{KF}(\mathrm{c}) \rightarrow \mathrm{MUF}_{6}(\mathrm{c})+\mathrm{KOH}(\mathrm{aq}) *+4 \mathrm{KCl}(\mathrm{c})
$$

The values used for $\triangle H f \mathrm{KOH}\left(12 \mathrm{OH}_{2} \mathrm{O}\right)=-115.077 \mathrm{kcal} / \mathrm{mol}$ and $\Delta \mathrm{Hf}$ $\mathrm{H}_{2} \mathrm{O}_{2}(250 \mathrm{H} \mathrm{O})=-45.69 \mathrm{kcal} / \mathrm{mol}$ are adjusted from Wagman et al. (1973, etc.) to be compatible with CODATA selections. 
$\mathrm{NaUF}_{7}(\mathrm{c})$ and $\mathrm{Na}_{2} \mathrm{UF}_{8}(\mathrm{c})$

Katz (1964, 1966) measured the vapor pressure of $\mathrm{UF}_{6}(\mathrm{~g})$ (gas evolution) over $\mathrm{UF}_{6} \cdot \mathrm{NaF}(\mathrm{c})$ and $\mathrm{UF}_{6} \cdot 2 \mathrm{NaF}(\mathrm{c})$ and reported (1966):

$$
\begin{gathered}
2\left(\mathrm{UF}_{6} \cdot \mathrm{NaF}(\mathrm{c}) \rightarrow \mathrm{UF}_{6}(\mathrm{~g})+\mathrm{UF}_{6} \cdot 2 \mathrm{NaF}(\mathrm{c})\right. \\
\log \mathrm{P}(\mathrm{atm})=8.18-3.4 \times 10^{3} / \mathrm{T} \quad(340-400 \mathrm{~K}) \\
\Delta G_{1}=15,900-37.4 \mathrm{~T} \mathrm{cal} / \mathrm{mol}
\end{gathered}
$$

and (1964):

$$
\begin{gathered}
\mathrm{UF}_{6} \cdot 2 \mathrm{NaF}(\mathrm{c}) \rightarrow \mathrm{UF}_{6}(\mathrm{~g})+2 \mathrm{NaF}(\mathrm{c}) \\
\log \mathrm{P}(\mathrm{atm})=6.37-4.18 \times 10^{3} / \mathrm{T}(500-573 \mathrm{~K}) \\
\Delta G_{2}=19,100-29.1 \mathrm{~T} \mathrm{cal} / \mathrm{mol}
\end{gathered}
$$

Cathers et al. (1958) reported the existence of $\mathrm{UF}_{6} \cdot 3 \mathrm{NaF}(\mathrm{c})$ and measured the $\mathrm{UF}_{6}(g)$ vapor pressure over it by the transpiration method (626 to $873 \mathrm{~K}$ ) as did Groves (1961).

However, Katz (1964) found no evidence for $\mathrm{UF}_{6} \cdot 3 \mathrm{NaF}$ and indicated that the measurements by Cather et al. (1958) were on $\mathrm{UF}_{6} \cdot 2 \mathrm{NaF}(\mathrm{c})$. Malm et al. (1966) prepared $\mathrm{UF}_{6}{ }^{\circ \mathrm{NaF}}$ and measured the $\mathrm{UF}_{6}$ vapor pressure at $373 \mathrm{~K} \sim 35 \mathrm{~mm}$, in fair agreement with Katz's measurements.

Tentatively the measurements of Katz for the systems specified a re accepted and, with an estimated $\Delta C_{\mathrm{p}} \approx-11 \mathrm{cal} / \mathrm{mol} \cdot \mathrm{K}, \Delta H_{1}=16.6$ and $\Delta \mathrm{H}_{2}=21.5 \mathrm{kcal} / \mathrm{mol} \mathrm{UF}_{6}$ from which the tabulated $\Delta \mathrm{Hf}^{\circ}{ }^{\prime} \mathrm{s}$ are obtained. 
$3.302 \quad U-F-O-M$ Compounds

$\mathrm{M}_{3} \mathrm{UO}_{2} \mathrm{~F}_{5}(\mathrm{c})(\mathrm{M}=\mathrm{Na}, \mathrm{K}, \mathrm{Rb}, \mathrm{Cs})$

Mukhametshina et al. (1974b) measured the $\Delta H^{\prime}$ 's of solution of $\mathrm{MF}(\mathrm{c}), \mathrm{UO}_{2} \mathrm{~F}_{2}(\mathrm{c})$, and $\mathrm{M}_{3} \mathrm{UO}_{2} \mathrm{~F}_{5}$ (c) in $2 \mathrm{M} \mathrm{HCl}$. These measurements lead to the following:

$$
\begin{aligned}
& 3 \mathrm{MF}(\mathrm{c})+\mathrm{UO}_{2} \mathrm{~F}_{2}(\mathrm{c}) \rightarrow \mathrm{M}_{3} \mathrm{UO}_{2} \mathrm{~F}_{5}(\mathrm{c}) ; \Delta \mathrm{H} \\
& \mathrm{M} \quad \triangle \mathrm{H} \mathrm{kcal} / \mathrm{mol} \\
& \mathrm{M}_{3} \mathrm{UO}_{2} \mathrm{~F}_{5}(\mathrm{c}) \\
& \mathrm{Na} \quad-7.58 \pm 0.27 \\
& \mathrm{~K} \quad-28.82 \pm 0.26 \\
& \mathrm{Rb} \quad-32.95 \pm 0.66 \\
& \text { Cs } \quad-34.86 \pm 1.38
\end{aligned}
$$

The selected values are based on these relationships.

$\mathrm{M}\left(\mathrm{UO}_{2}\right)_{2} \mathrm{~F}_{5}(\mathrm{c})(\mathrm{M}=\mathrm{Na}, \mathrm{K}, \mathrm{Rb}, \mathrm{Cs})$

Suponitskii et a . (1974) from a series of $\Delta H^{\prime}$ 's of solution of these compounds in $2 \mathrm{M}$ HCl obtained the following enthalpies for formation from $\mathrm{MF}(\mathrm{c})$ and $\mathrm{UO}_{2} \mathrm{~F}_{2}(\mathrm{c})$ :

$$
\begin{array}{cc}
\mathrm{MF}(\mathrm{c})+ & \left.2 \mathrm{UO}_{2} \mathrm{~F}_{2}(\mathrm{c}) \rightarrow \mathrm{M}_{2} \mathrm{UO}_{2}\right)_{2} \mathrm{~F}_{5}(\mathrm{c}) ; \Delta \mathrm{H} \\
\mathrm{M} & \Delta \mathrm{H} \mathrm{kcal} / \mathrm{mol} \\
\mathrm{Na}\left(\mathrm{UO}_{2}\right)_{2} \mathrm{~F}_{5} \\
\mathrm{~K} & -8.15 \pm 0.22 \\
\mathrm{Rb} & -18.64 \pm 0.24 \\
\mathrm{Cs} & -23.28 \pm 0.62 \\
\end{array}
$$

The selected values are based on these results. 
$\underline{\mathrm{M}_{5}\left(\mathrm{UO}_{2}\right)_{2} \mathrm{~F}_{9}(\mathrm{c})(\mathrm{M}=\mathrm{K}, \mathrm{Rb}, \mathrm{Cs})}$

Mukhametshina et al (1974a), from a series of $\Delta H^{\prime} s$ of solution of these compounds in $\mathrm{HC} 1$ reported, for the enthalpies of reaction of alkali metal fluorides with $\mathrm{UO}_{2} \mathrm{~F}_{2}(c)$ :

$$
\begin{array}{cc}
5 \mathrm{MF}(\mathrm{c})+2 \mathrm{UO}_{2} \mathrm{~F}_{2}(\mathrm{c}) & \rightarrow \mathrm{M}_{5}\left(\mathrm{UO}_{2}\right)_{2} \mathrm{~F}_{9}(\mathrm{c}) ; \Delta \mathrm{H} \\
\mathrm{M} & \Delta \mathrm{H} \\
& \mathrm{kcal} / \mathrm{mo} 1 \\
& \mathrm{M}_{5}\left(\mathrm{UO}_{2}\right)_{2} \mathrm{~F}_{9}(\mathrm{c}) \\
\mathrm{K} & -52.76 \pm 1.2 \\
\mathrm{Rb} & -63.38 \pm 1.5 \\
\mathrm{Cs} & -68.16 \pm 2.25
\end{array}
$$

The selected values are based on these tabulated numbers. 
$3.303 \quad \mathrm{U}-\mathrm{CI}-\mathrm{M}$ Compounds

$\mathrm{MUCl}_{5}(\mathrm{c})(\mathrm{M}=\mathrm{K}, \mathrm{Rb}, \mathrm{Cs})$

The following summarizes the $\Delta H^{\prime}$ 's for the formation of MUC $1_{5}$ (c) from the components salts $\left(\mathrm{MCl}\right.$ (c) and $\mathrm{UCl}_{4}$ (c)) from measurements in $2 \% \mathrm{HCl}, 0.5 \% \mathrm{FeCl}_{3}$ solutions: they are accepted.

$$
\mathrm{MCl}(\mathrm{c})+\mathrm{UCl}_{4}(\mathrm{c}) \rightarrow \mathrm{MUCl}_{5}(\mathrm{c}) ; \Delta \mathrm{H}
$$

$\triangle \mathrm{H} \mathrm{kcal} / \mathrm{mol} \mathrm{MUOl}_{5}$

$$
\mathrm{K} \quad \mathrm{Rb} \quad \mathrm{Cs}
$$

Martynova et a 1 (1968) $-5.5 \pm 0.5$

Vdovenko et al. (1974) $\quad-6.8 \pm 0.6 \quad-10.5 \pm 0.8 \quad-13.6 \pm 0.8$

$\mathrm{M}_{2} \mathrm{UCl}_{6}(\mathrm{c})(\mathrm{M}=\mathrm{Li}, \mathrm{Na}, \mathrm{NaK} / 2, \mathrm{~K}, \mathrm{Rb}, \mathrm{Cs})$

The following summarizes the $\Delta H^{\prime}$ 's for the formation of

$\mathrm{M}_{2} \mathrm{UCl}_{6}(\mathrm{c})$ from the component salts $\left(\mathrm{MCl}(\mathrm{c})\right.$ and $\left.\mathrm{UCl} 1_{4}\right)$ ):

$2 \mathrm{MCl}$ (c) $+\mathrm{UCl}_{4}(\mathrm{c})-\mathrm{M}_{2} \mathrm{UCl}_{6}(\mathrm{c}) ; \Delta \mathrm{H}$

$\Delta \mathrm{H} \mathrm{kal} / \mathrm{mol} \mathrm{M}_{2} \mathrm{UCl}_{6}$

$\begin{array}{llllll}\mathrm{M}=\mathrm{Li} & \mathrm{Na} & \mathrm{NaK} / 2 & \mathrm{~K} & \mathrm{Rb} & \mathrm{Cs}\end{array}$

Martynova et a1. (1968)

$-1.5 \pm 0.6-6.0 \pm 0.6-9.8 \pm 0.6$

[measurements in $2 \% \mathrm{HCl}$,

$\left.0.5 \% \mathrm{FeCl}_{3}\right]$

Vdovenko et al. (1974) $1.1 \pm 0.6-1.7 \pm 0.7$

$-9.4 \pm 0.5-16.1 \pm 0.6-24.1 \pm 0.8$

[measurements in $2 \% \mathrm{HCl}$,

$\left.0.5 \% \mathrm{FeCl}_{3}\right]$

Fuger and Brown (1971)

[measurements in $1 \mathrm{M} \mathrm{HC} 1$ ]

$-26.7 \pm 0.3$

[measurements in $6 \mathrm{M} \mathrm{HCl]}$

The selected values were obtained from the average $\Delta H$. 
$\underline{\mathrm{Rb}_{4} \mathrm{UCl}_{8}(\mathrm{c})}$

The results of Vdovenko et al. (1974), from measurements in $2 \%$ $\mathrm{HCl}, 0.5 \% \mathrm{FeCl}_{3}$ solutions lead to:

$4 \mathrm{RbCl}(\mathrm{c})+\mathrm{UCl}_{4}(\mathrm{c}) \rightarrow \mathrm{Rb}_{4} \mathrm{UCl}_{8}(\mathrm{c}) ; \Delta \mathrm{H}=-16.5 \pm 0.8 \mathrm{kcal} / \mathrm{mol} \mathrm{Rb}_{4} \mathrm{UCl}_{8}(\mathrm{c})$ This is the basis for the selected value.

$\mathrm{CsU}_{2} \mathrm{Cl}_{9}(\mathrm{c})$

The results of Vdovenko et al. (1974) from measurements in $2 \% \mathrm{HCl}$, $0.5 \% \mathrm{FeCl}_{3}$ solutions lead to:

$$
\mathrm{CsCl}(\mathrm{c})+2 \mathrm{UCl}_{4}(\mathrm{c}) \rightarrow \mathrm{CsU}_{2} \mathrm{Cl}_{9}(\mathrm{c}) ; \Delta \mathrm{H}=-13.1 \pm 1.4 \mathrm{kcal} / \mathrm{mol} \mathrm{CsU}_{2} \mathrm{Cl}_{9}
$$

This is the basis for the selected value. 
$\mathrm{MUCl}_{6}(\mathrm{c})(\mathrm{M}=\mathrm{Na}(\alpha$ and 3$), \mathrm{K}, \mathrm{Rb}$, and $\mathrm{Cs})$

Kudryashov et al. (1978b) measured the enthalpy of oxidation of the alkali metal uranium (V) hexachlorides, $\mathrm{MUCl}_{6}$, in $2 \% \mathrm{HCl}, 0.5 \%$ $\mathrm{FeCl}_{3}$ aqueous solutions:

$$
\mathrm{IUCl}_{6}(\mathrm{c})+\left[\mathrm{FeCl}_{3}+2 \mathrm{H}_{2} \mathrm{O}\right](\mathrm{aq}) \rightarrow\left[\mathrm{UO}_{2} \mathrm{Cl}_{2}+\mathrm{FeCl}_{2}+4 \mathrm{HCl}+\mathrm{MCl}\right](\mathrm{aq}) ; \Delta \mathrm{H}_{1}
$$

With their measured $\Delta H^{\prime}$ 's of solution for $\mathrm{FeCl}_{3}(\mathrm{c})(-32.55 \pm 0.1 \mathrm{kcal} / \mathrm{mol})$, $\mathrm{FeCl}_{2}(\mathrm{c})(-18 \cdot 7 \pm 0.2 \mathrm{kcal} / \mathrm{mol})$ and $\mathrm{MCl}(\mathrm{c})$ cited below and the results of Vdovenko et al. (1973) for the reaction of $\mathrm{UCl}_{4}$ (c) in the same media :

$$
\begin{gathered}
\mathrm{UCl}_{4}(\mathrm{c})+\left[2 \mathrm{FeCl}_{3}+2 \mathrm{H}_{2} \mathrm{O}\right](\mathrm{aq}) \rightarrow\left[\mathrm{UO}_{2} \mathrm{Cl}_{2}+2 \mathrm{FeCl}_{2}+4 \mathrm{HCl}\right](\mathrm{aq}) ; \\
\Delta \mathrm{H}_{2}=-45.3 \pm 0.1 \mathrm{kcal} / \mathrm{mol}
\end{gathered}
$$

the following summary reaction is obtained:

\begin{tabular}{|c|c|c|c|}
\hline $\mathrm{MUCl}_{6}(\mathrm{c})$ & $\Delta \mathrm{H}_{1}$ & $\begin{array}{l}\triangle \mathrm{HHCl}(\mathrm{c}) \\
\mathrm{kcal} / \mathrm{mol}\end{array}$ & $\Delta \mathrm{H}_{3}$ \\
\hline $\mathrm{Na}(\alpha)$ & $-61.6=0.5$ & $1.19 \pm 0.02$ & $3.6 \pm 0.6$ \\
\hline $\mathrm{Na}(\beta)$ & $-61.4 \pm 0.4$ & $1.19 \pm 0.02$ & $3.4=0.5$ \\
\hline $\mathrm{K}$ & $-51.7 \pm 0.3$ & $4.37 \pm 0.02$ & $-3.0=0.5$ \\
\hline $\mathrm{Rb}$ & $-45.0=0.2$ & $4.08 \div 0.02$ & $-10.1 \pm 0.4$ \\
\hline Cs & $-41.9 \pm 0.2$ & $4.01 \pm 0.02$ & $-13.2 \pm 0.4$ \\
\hline
\end{tabular}

$$
\mathrm{UCl}_{4}(\mathrm{c})+\mathrm{FeCl}_{3}(\mathrm{c})+\mathrm{MCl}(\mathrm{c}) \rightarrow \mathrm{FeCl}_{2}(\mathrm{c})+\mathrm{MUCl}_{6}(\mathrm{c}) ; \Delta \mathrm{H}_{3}
$$

The $\Delta \mathrm{Hf}^{\circ}$ 's are obtained from $\Delta \mathrm{H}_{3}$. 


\section{$3.304 \quad \mathrm{U}-\mathrm{Br}-\mathrm{M}$ Compounds \\ $\underline{\mathrm{M}_{2} \mathrm{UBr}_{6}(\mathrm{c}) \quad(\mathrm{M}=\mathrm{Rb}, \mathrm{Cs})}$}

The results of Vdovenko et al. (1973), from the $\Delta H^{\prime}$ s of solution of the components in $0.5 \% \mathrm{FeCl}_{3}, 2 \% \mathrm{HCl}$ lead to:

$$
2 \mathrm{RbBr}(\mathrm{c})+\mathrm{UBr}_{4}(\mathrm{c}) \rightarrow \mathrm{Rb}_{2} \mathrm{UBr}_{6}(\mathrm{c}) ; \Delta \mathrm{H}_{1}=-14.86 \pm 0.15 \mathrm{kcal} / \mathrm{mol} \mathrm{Rb}_{2} \mathrm{UBr}_{6}
$$

$$
2 \mathrm{CsBr}(\mathrm{c})+\mathrm{UBr}_{4}(\mathrm{c}) \rightarrow \mathrm{Cs}_{2} \mathrm{UBr}_{6}(\mathrm{c}) ; \Delta_{2}=-23.02 \pm 0.15 \mathrm{kcal} / \mathrm{mol} \mathrm{Cs}_{2} \mathrm{UBr}_{6}
$$

These are accepted. 
III. Tables of Values for $\Delta \mathrm{Hf}^{\circ}, \Delta \mathrm{Gf}{ }^{\circ}, \mathrm{S}^{\circ}, \mathrm{C}_{\mathrm{p}}{ }^{\circ}$, and $\mathrm{H}-\mathrm{H}_{0}$ at $298.15 \mathrm{~K}$ and $\Delta \mathrm{Hf}^{\circ}$ at $\mathrm{O} \mathrm{K}$ for the Uranium-Halogen Containing Compounds

The values are consistent with the CODATA key values for thermodynamics and the IAEA series, "The Chemical Thermodynamics of Actinide Elements and Compounds".

Included in the tabular summary are values for the non-halogen containing uranium compounds which were necessary for this evaluation.

The compounds covered are listed in the standard order of arrangement except for those containing the alkali metals which are arranged by compound class of the uranium-halogen compound with the a $1 \mathrm{kali}$ me tal.

See Section I - 2.5 and Section I - 2.4 for the conventions used for the Table headings, the chemical formulae and physical states. 
Note Added in Proof

There are significant new results that necessitate modification of the values selected for certain uranium fluorides. These adjusted values are included in the tabulation.

The calorimetric measurements of Cordfunke, (private communication, June 1980) , esult in:

$$
\begin{aligned}
& \Delta \mathrm{Hf}^{\circ} \mathrm{UF}_{3}(\mathrm{c})=-360.6 \pm 1.0 \mathrm{kcal} / \mathrm{mol} \\
& \Delta \mathrm{Hf}^{\circ} \mathrm{UF}_{4}(\mathrm{c})=-459.1 \pm 1.0 \mathrm{kcal} / \mathrm{mol}
\end{aligned}
$$

These values are based on two different measurement paths. The paths are:

1. The direct fluorinations of $\mathrm{UF}_{3}(\mathrm{c})$ and $\mathrm{UF}_{4}(\mathrm{c})$ to $\mathrm{UF}_{6}(\mathrm{c})$.

2. Solution measurements of $\mathrm{UF}_{3}(c), \mathrm{UF}_{4}(c)$, and $\mathrm{UO}_{3}(c, \gamma)$ and and $\mathrm{U}_{3} \mathrm{O}_{8}(\mathrm{c})$ in a $\mathrm{H}_{2} \mathrm{SO}_{4}, \mathrm{Ce}\left(\mathrm{SO}_{4}\right)_{2}, \mathrm{H}_{3} \mathrm{BO}_{3}$ aqueous medium.

The above values are accepted and result in the adjustment of the values for $U F(g), U F_{2}(g), U F_{3}(g), U F_{4}(g)$ and $U F_{4} \cdot 2 \cdot 5 H_{2} \mathrm{O}(\mathrm{c})$ as well, since they are all dependent upon the $\Delta \mathrm{Hf}^{\circ} \mathrm{UF}_{4}$ (c).

The values for $\mathrm{UF}_{4.25}(\mathrm{c}), \mathrm{UF}_{4.5}(\mathrm{c}), \mathrm{UF}_{5}(, \alpha)$ and $\mathrm{UF}_{5}(\mathrm{c}, \mathrm{B})$ and $\mathrm{UF}_{5}(\mathrm{~g})$ are also dependent upon $\mathrm{UF}_{4}(\mathrm{c})$; however, there are indications from solution calorimetric measurements in progress by O'Hare (private communication, June 1980) on $\mathrm{UF}_{5}(c, \alpha)$ and $\mathrm{UF}_{5}(c, \beta)$ that their $\Delta \mathrm{Hf}^{\circ}$ 's should be more positive, rather than more negative as required by the above cited $\Delta \mathrm{Hf}^{\circ} \mathrm{UF}_{4}(\mathrm{c})$ and the Agron (1958) data.

Until the situation regarding $\mathrm{UF}_{5}(c, \alpha)$ and $(c, \beta)$ is clarified, the values for these two compounds and for $\mathrm{UF}_{4.25}, \mathrm{UF}_{4.5}(\mathrm{c})$, and $\mathrm{UF}_{5}(g)$ are maintained as in Section II, but with larger uncertainties. 
In addition, Westrum (private communication, June 1980) measured the low temperature heat capacity for $\mathrm{UF}_{3}(\mathrm{c})$ resulting in $\mathrm{S}^{\circ}=$ $29.50 \pm 0.10$ and $\mathrm{C}_{\mathrm{p}}{ }^{\circ}=22.73 \pm 0.10 \mathrm{cal} / \mathrm{mol} \cdot \mathrm{K}$ which replace the estimated $S^{\circ}=30.0 \pm 1.0$ and $C_{p}{ }^{\circ}=23.4 \pm 1.0 \mathrm{cal} / \mathrm{mol} \cdot \mathrm{K}$. 


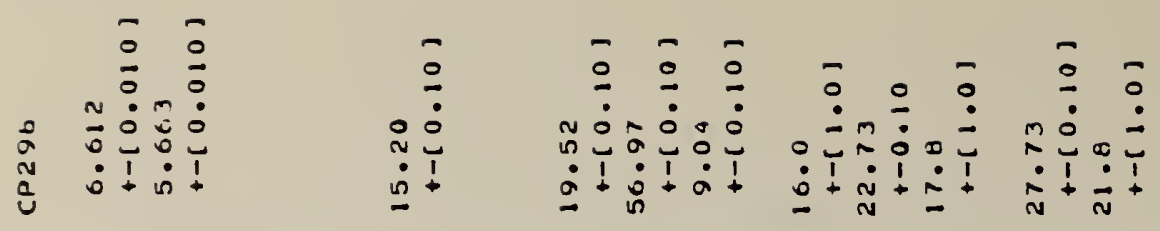

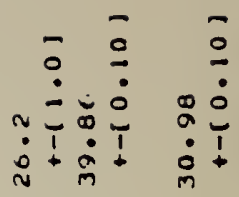

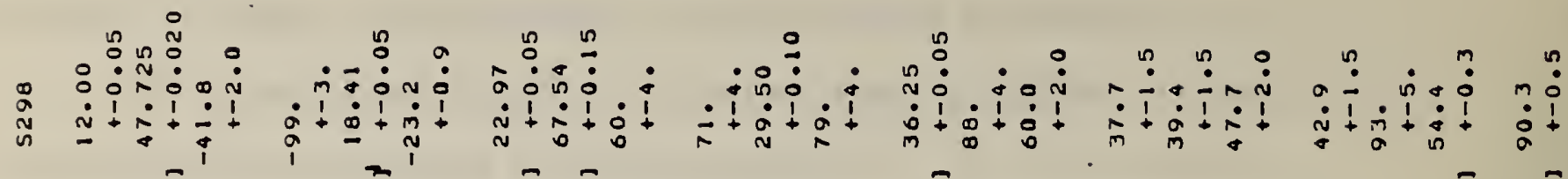

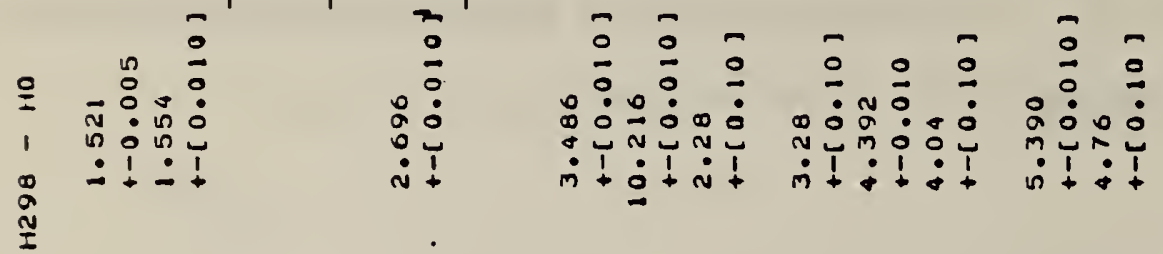

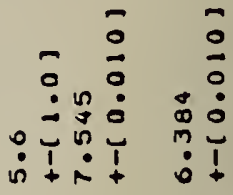

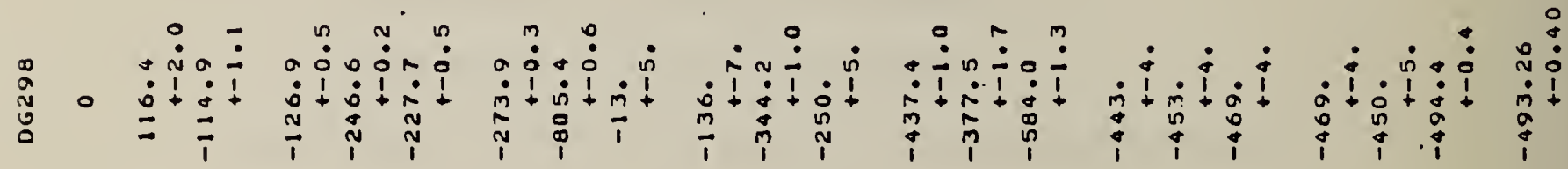

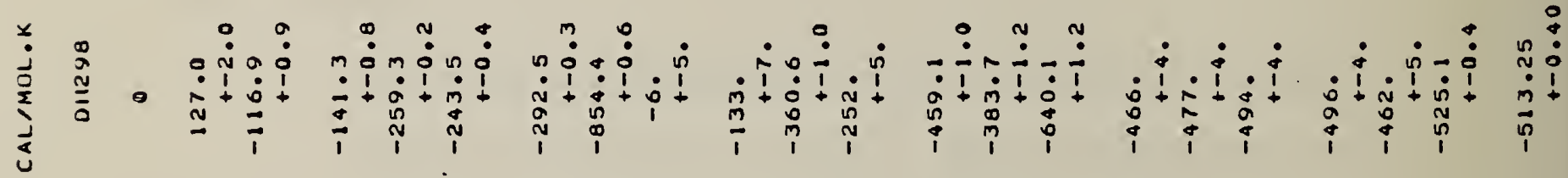

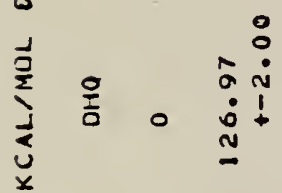

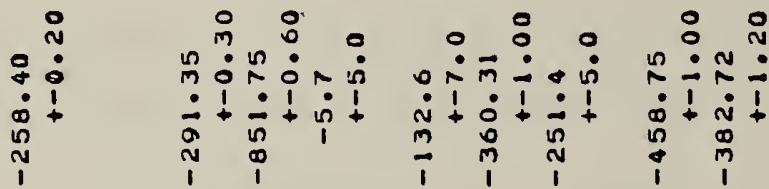

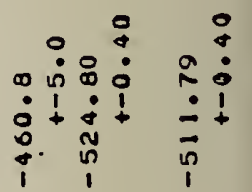

$\geq 5$

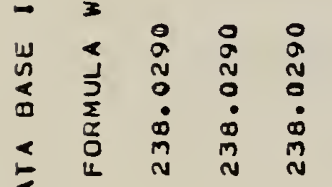

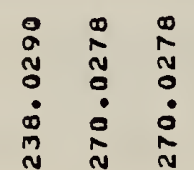

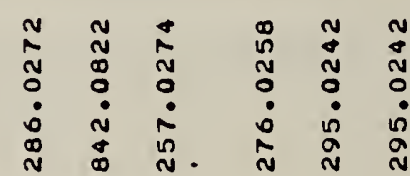

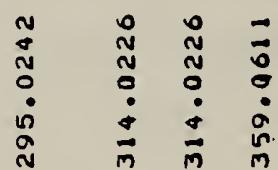

$\begin{array}{ll}\overrightarrow{0} & \stackrel{N}{N} \\ \vdots & \stackrel{0}{0} \\ \text { in } & \frac{m}{n}\end{array}$

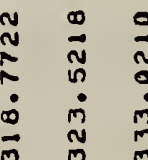

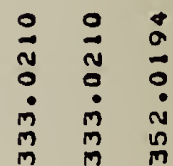

$\stackrel{+}{a}$

z

高

s

竞

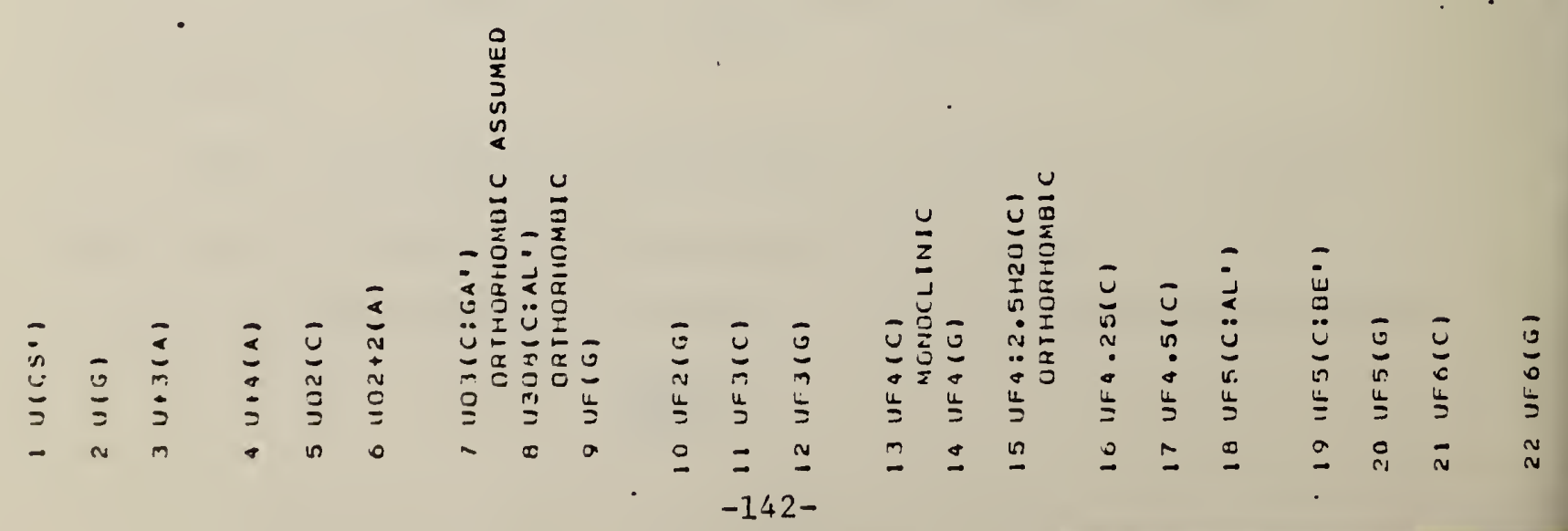

s

$\frac{a}{\tilde{c}}$ 


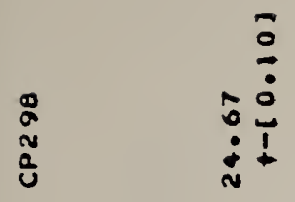

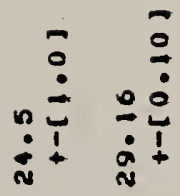

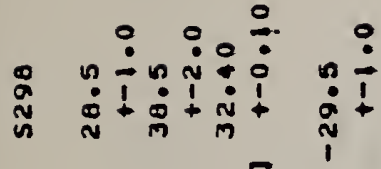

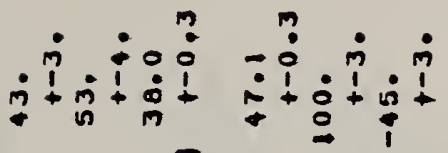

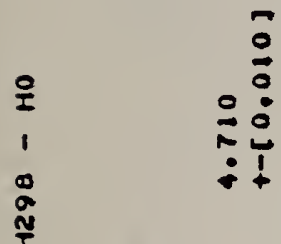

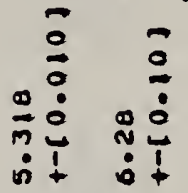

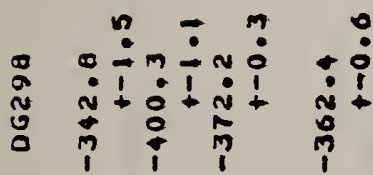

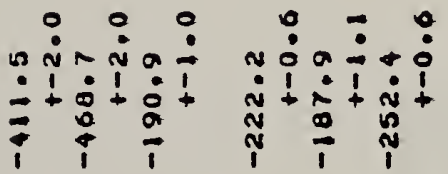

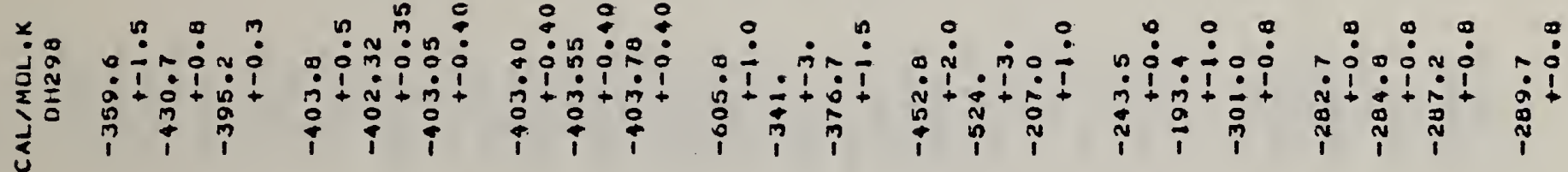

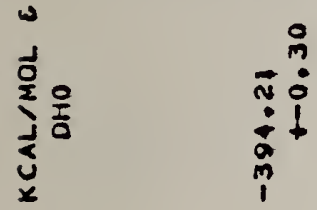

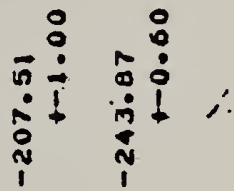

$z$

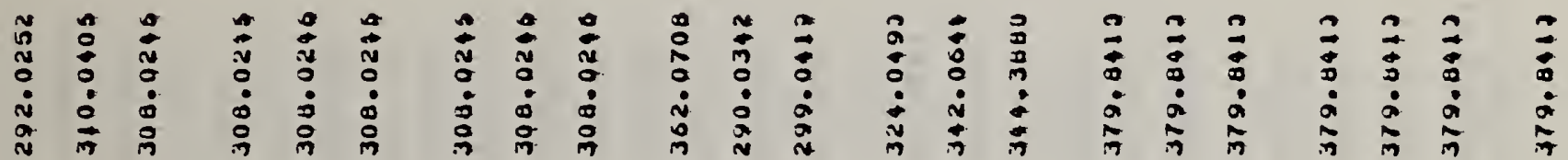

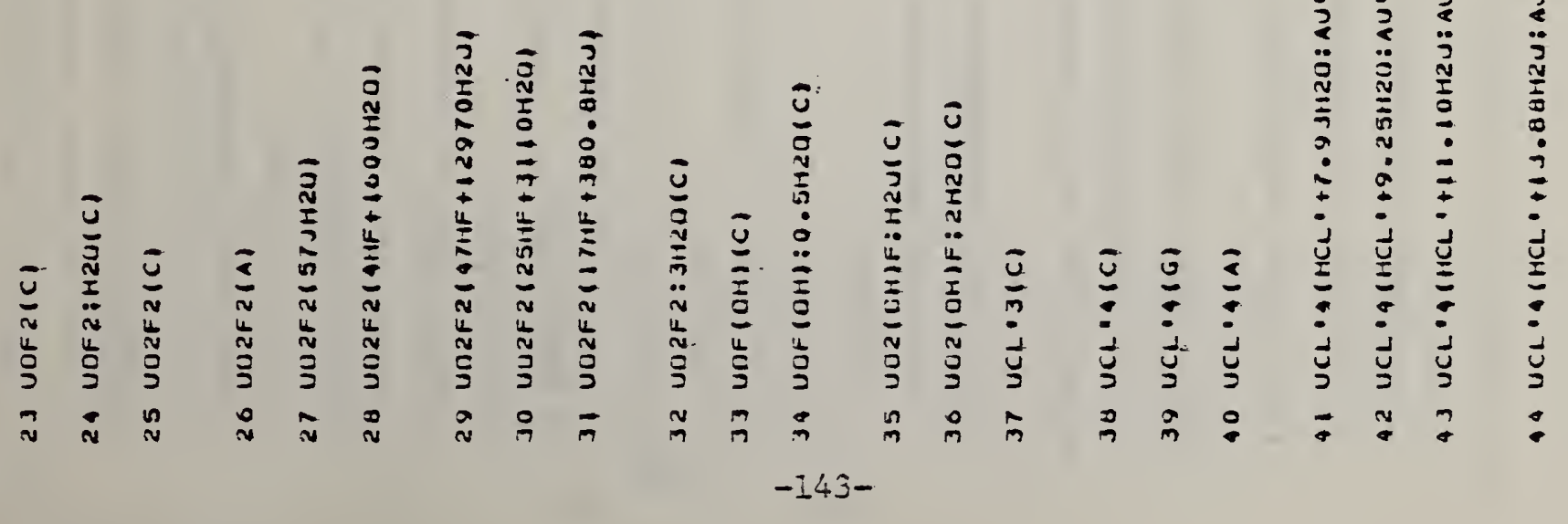




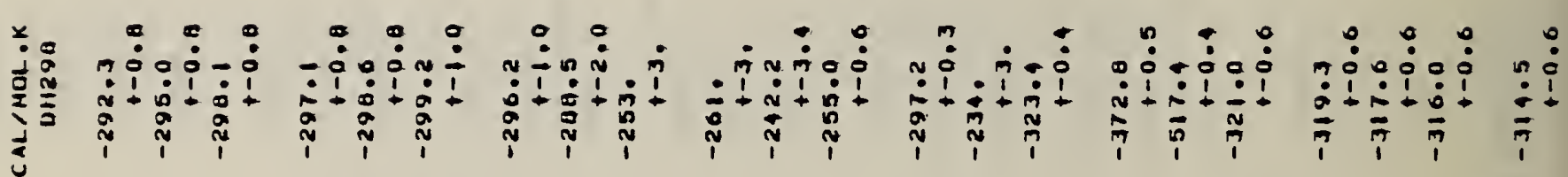


0
2
2
2

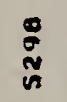

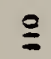

1
$\stackrel{2}{N}$
$\stackrel{2}{N}$

$\underset{3}{3}$

$\sum_{\substack{3 \\ 0}}^{\frac{1}{2}}$

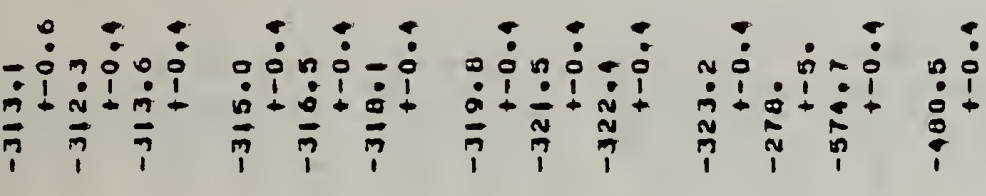

$\frac{\substack{x \\ \frac{1}{2}}}{\frac{1}{2}}$

II

ड़े

z

章

3

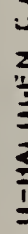

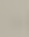

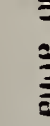

$\stackrel{3}{3}$

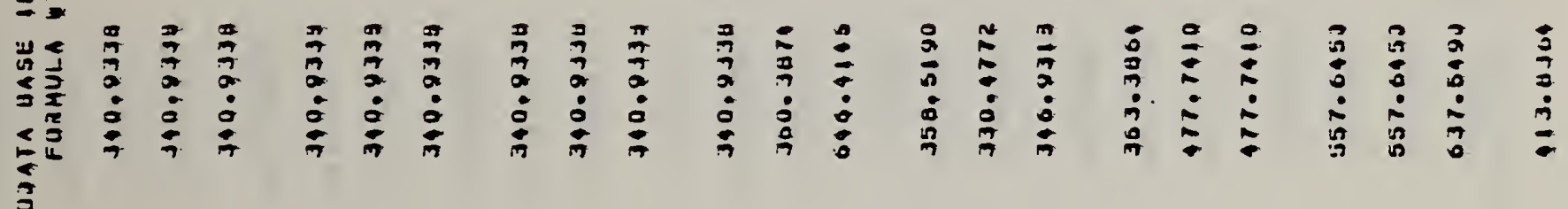

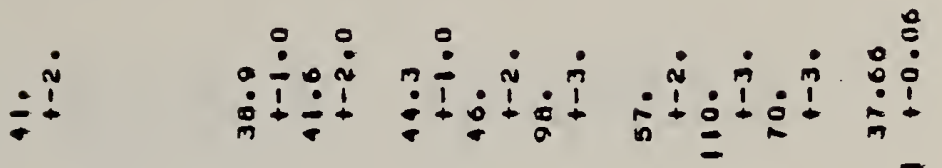

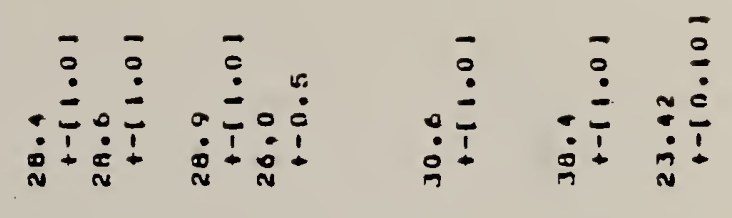

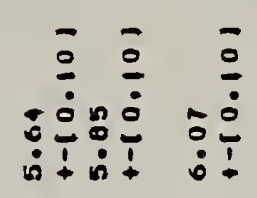

:

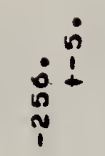

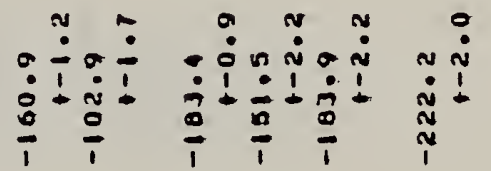

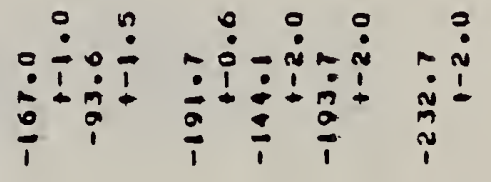

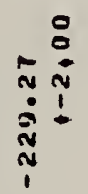

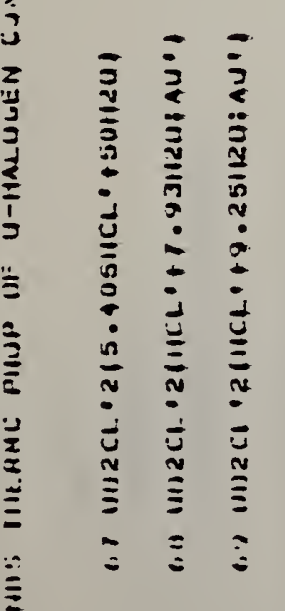

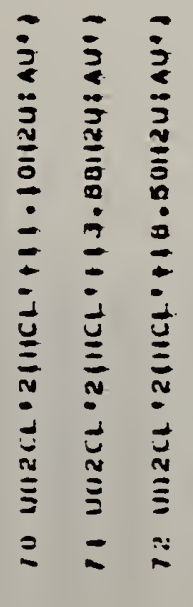

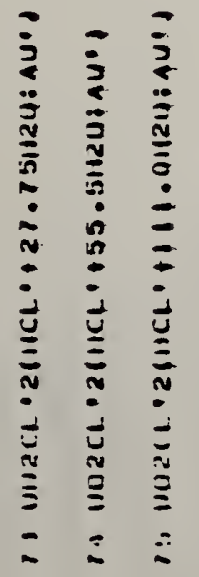

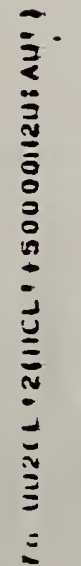

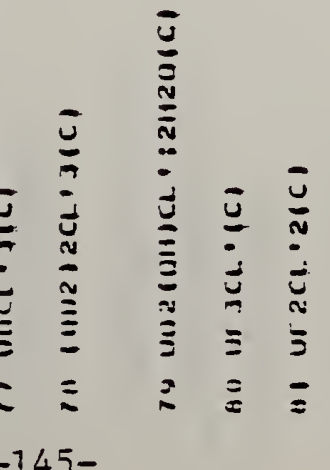

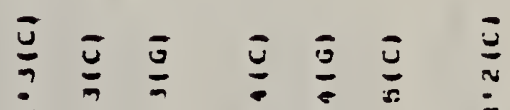




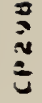

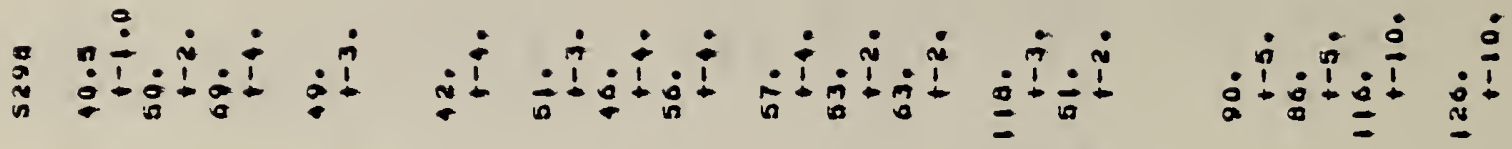

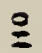

1
0
0

กิด

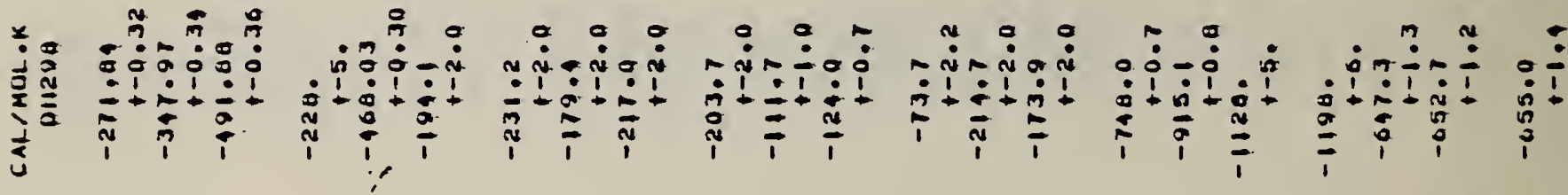

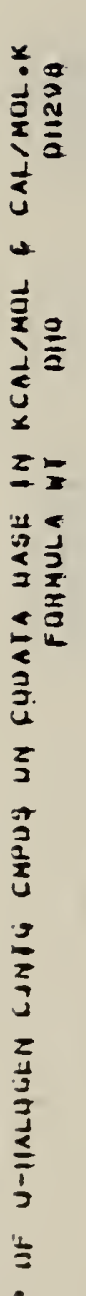

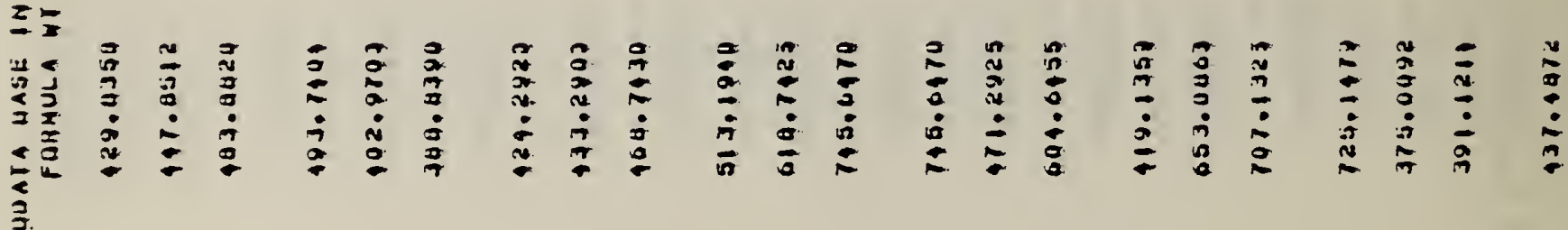

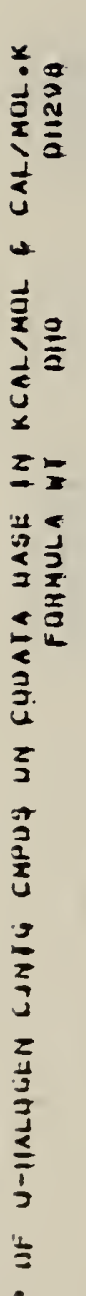

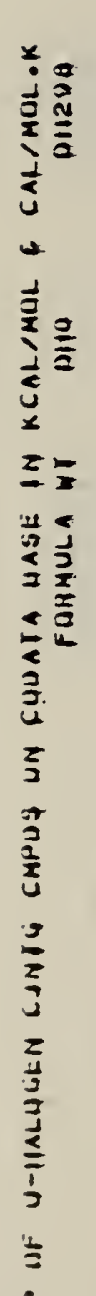

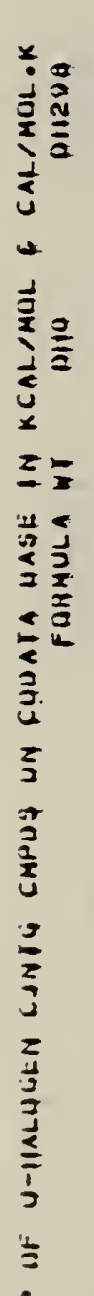

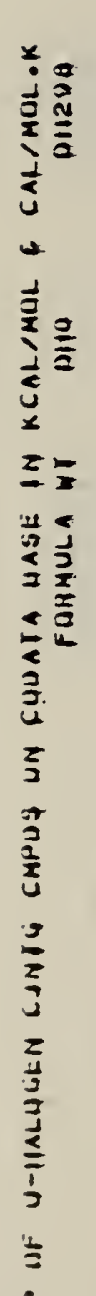

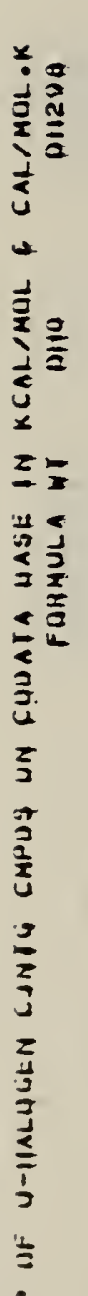

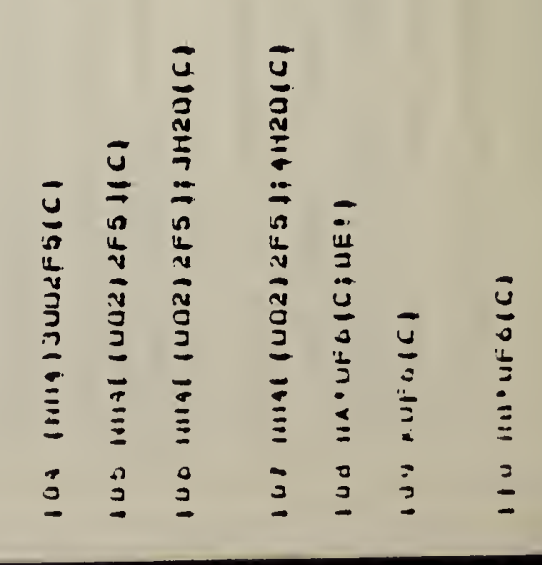




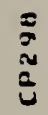

$\dot{0}$
$\dot{n}$

$\stackrel{9}{2}$
1
0
2
2

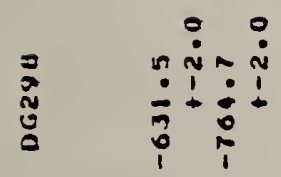

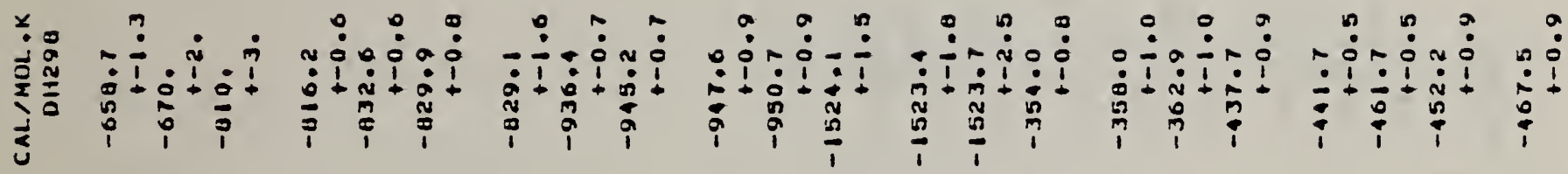

4

$\sum_{\substack{\frac{1}{2} \\ \frac{1}{2}}}^{\frac{1}{2}}$

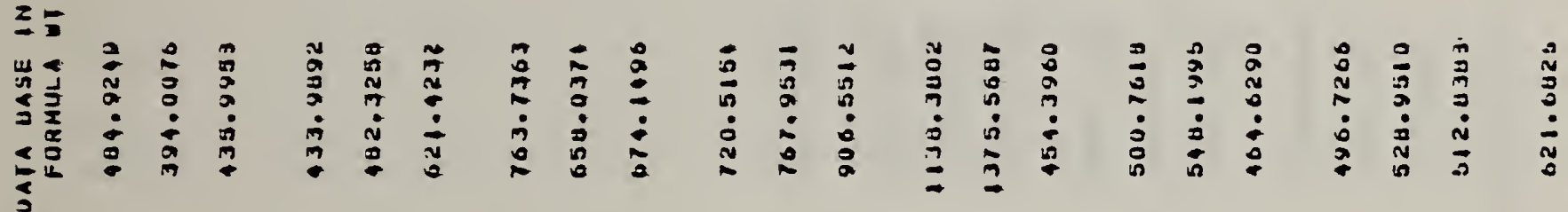

కృ

2

尔

3

$\Xi$ 


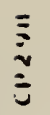

疋

$\stackrel{9}{=}$

:

$a$
ปै
2

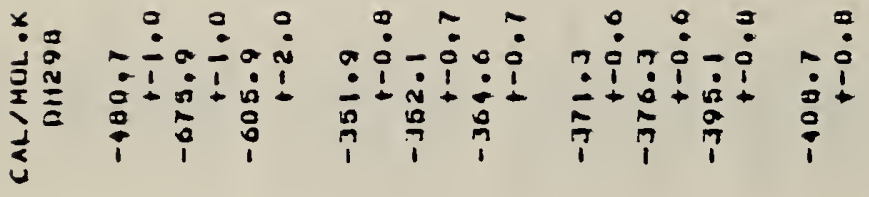

2

$\sum_{\substack{x \\ x}}^{\frac{1}{2}} \frac{1}{a}$

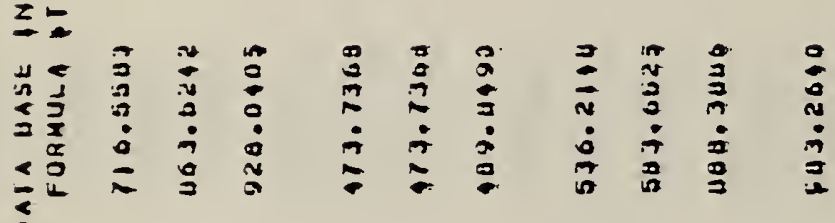

ป

Z

ปै

3

$z$

$\frac{5}{3}$

$\frac{1}{3}$

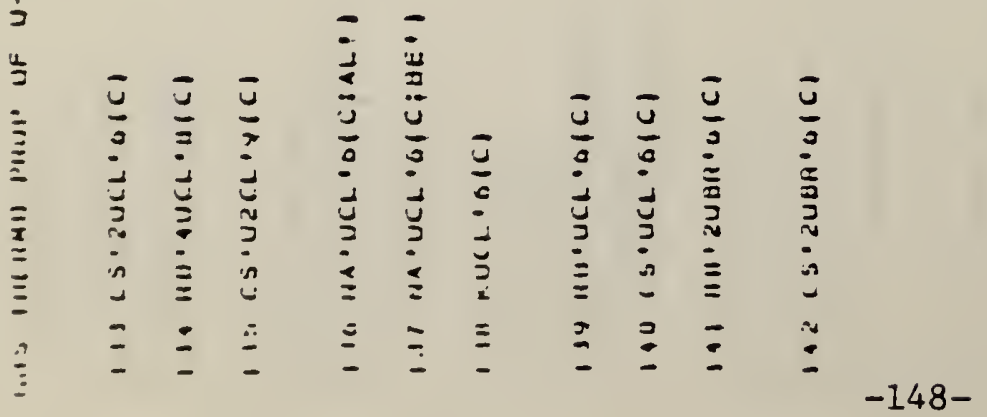


Iy Bibliograbhy

ngron: P. A.; Paper 5?, Gin in Katz: J. I. and Rabinowiteh: E. PAS., U.S. AEC TIJ

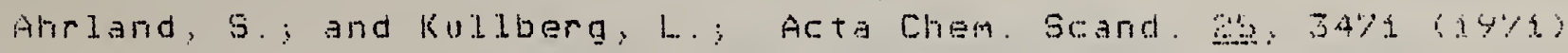

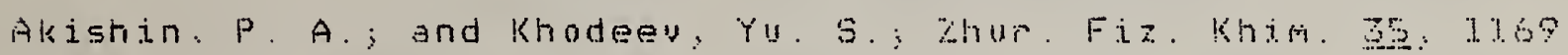
(. i. 96 i)

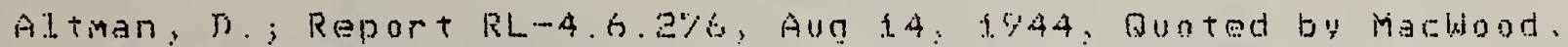
G.; Paper 58, 543 in Katz, T. J.; and kabinowitch, F eds. U. 5. 8. 54.5 in Katz, J. J.; and Rabinowitch, E., eds. U. S. AlEC Tib$5290,(1950)$

Arque, G. R.; Mercer: E. E.; and Cobble, J. W. J Phye Chem. bE: (2041(196)

Armstrong, G. T. : Mirantz, S.; and Coyle: T. J. Am. Chem. Soc. Q1. $3798(1959)$

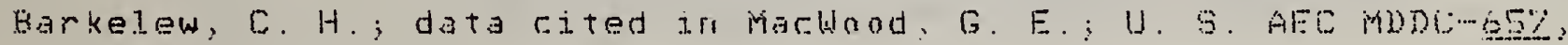
$7 \xi p(1946)$

Eattles, S. E.; Shinn: W. A. : and Bi. ackburn: P. E. : J. Chom. Thermoduram. 4.425 (4972)

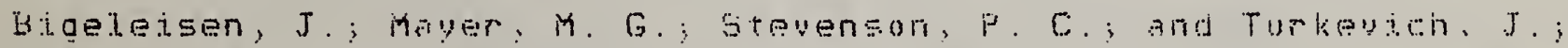
Chem. Phys. is, 440 (i948)

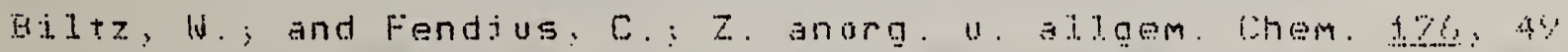
(1928)

bitair, A.; and Inie, H.; J. Inorg. and Nuclear Clom. $35.3 y \%$ (1973)

Grewer, L.; Bromley, L. A.: Gilles, P. W. ; and Lotaren, L... Paper 35. Zis in katz, J. J.; and Rabinowitrh, E., eds., U. S. Ate

$110-5290(1958)$

Frickwedde, F. G.; quoted in Katz, J. J.; and Rabinowitch, E.;

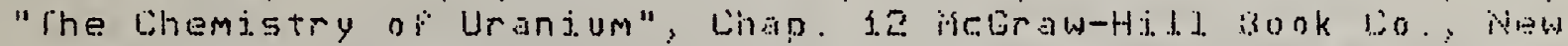
York (195.)

Brickwedde. F. G.; Hoge, H. J.; and Scott: R. B.: J. Chem. Pros. 1ㅇ․ $429(1948)$

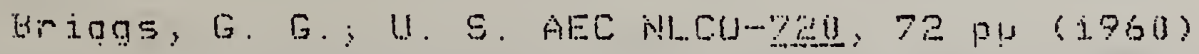

Curke, T. G.; Simith: D. F.; and Nielsen. A. H.; T. Ghem. Phys. Do. (it?5)

Burns, J. H. B Obarne: O. W.; and destrum, E. F. Jr. J Ghem.

Phus. 33: 387 (1960) 
Eathers, G. I.; Bennett, M. R. : and Jolley, R. I..; Ind. Fng. Chem. S10 $1709(1558)$

Chooorow, D. Ya.; and Chudinoy, E. T.; Soyiet Radiochemistry sul: $208(2968)$

Classen, H. H.; J. Chem. Phys. 30, 960 (1959)

Classen. H. H.; Weinstork, E.: and ialin, J. G.; I. Chem. Phys. ㄹ․ 426 (1956)

Clements, R. $\dot{m}$; and Barrow, R. F.; Chem. Commun. 1960, 2\%

CODATA Task Group on Fundamental Constante CODATA Bulletin ivo. II (Der. 9973 )

CUDATA Recommended Key Ualues for Thermodynamics 1975, CODATA Bu11. No.4Z, (Jan. $19 \%$ b), and Codata Special Report No. (Sept. 19, Codata, Paris

CODATa Rerommended Key Values for Thermodynamics á9\%, Cubala Bul1. No. Ze $(A p r i t 1978)$, Codata, Paris

Eook, 0. A.; and Eastman, E. 0.; U. S. AlC AECD gego, 3op Gopt. $1944)$

Cordfunke. E. H. P. Paper Si bo/7, 483-495, in Proceedings of the Symposiluin on Thermudynamics with Embingsis on Nuchear miateriaj.s and Atomic Transport in Solids. Vol. 1.1, oroanized by IAEA in

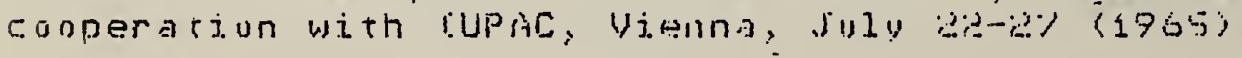

Cordfunke, E. H. P.; unpublished results, Priyate cominuication

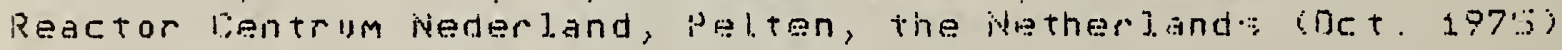

Cordfunke, E. H. P.; and Aling, P.; Trans. Faraday Soc. bi. bu (1965)

Cordfunke, E. H. P.; and O'Hare, P. A. G.; The Chemical Thermodunamics of ACtinjde Elements und Coinounds. Part 3 . in sicelidaneous Actinide Comnounds, IAEA, Vienna, (i\%"'7)

Cordfunke, E. H. F.; and Duwelt jes, w.; Priuate Communication,

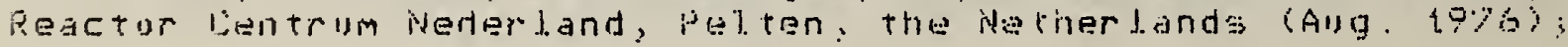
(3lso J. Chem. Thermodynam. 9.71 (x.9\%))

Cordfunke: E. H.P.; and Duweltjes, W. Private Communication Reactor lientruin vedertand. Pelten, the Netherlands (mareh by 7 )

Lordfunke, E. H. P.; Ouwelt jes, W.; and Prins, G.: J. Chem. Thermodunam. 241 ( 9976$)$

Cordfunke, E. H. P. Prins, G.; J. Tnorg. and Muclear Chem. Zs:

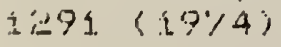


Cordfunke: E. H. F. Prins: C.; wan Vlagderen: P. I Inarg and Nuclear Lhem. $30,218 \%(197 \%)$

Dayidson, P.; Hackood, G.; and Streeter, I. Renort RL-4.t. 93

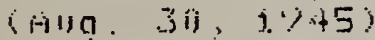

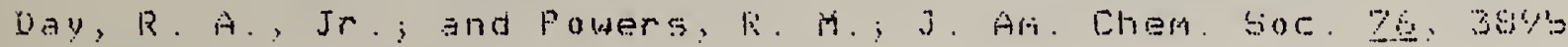
$(2954)$

Day, R. A., Ji.; Wilhite, R. N.; and fismiton, F, j). $T$. Am. Chem. Soc. $77,3180-3.80$ (1955)

Domange, L.; and Wohthuter, if ; Compt. rend. 228. 1591 (1944)

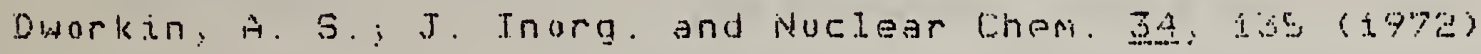

Egan, J. J.; 谁Coy, W.; and Eracker, J.: Thermodyn. Nucl. Mat' Ie. IAFA, Vi enna (1\%心e?

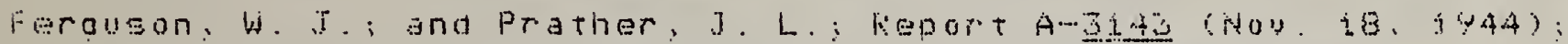
eited in Katz, J. J. ; and Rabinowitch. E.; "The Chemistry of

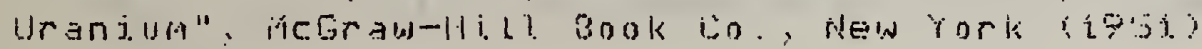

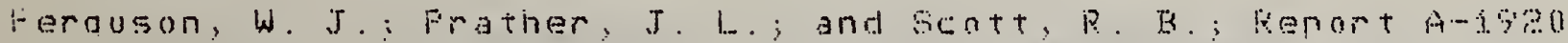
(ifay 3,1944 ); cited in katz: J. J.; and kabjowateh; E. "fire Chemistru of Uranjum": MeGraw-Hili Bank Co.. New York (19yi)

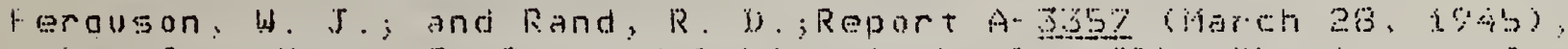
taken from Katz, J. J.; and liabinowitch, E.; "The chemistry of IJ anjum", MeGraw-iti.1! Book Lo.. Now York (1)5I)

Fitzaibbon: G. C.; Newton, T. H.; and Holley, C. E.; Calorinetry Coriferences? Seatt].e (Ju]y i\%,

Fitzgibbon, G. C.; Pryone; D.; and Holley, C. E. J J.; J. Chem. Ena.

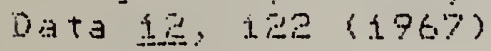

Fitzoibban, G. C.; Payone, D.: and Holley; C. F.; Jr. J Ghem. Ther-

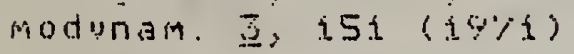

Fontana, E. J.; in Papers 35 and $36, K a t z, J$. J.; जut Rabinowiteh, E., edE.; U.S. AEC TID -5290 : (1.958)

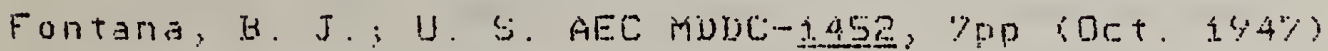

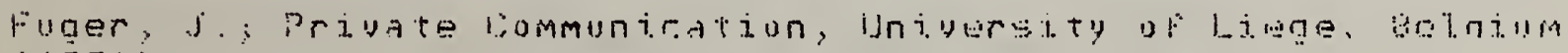
(1976)

Fuaer, J.: and Brown: D. J.: J. Chem. Soc. A19\%0: 763

Fuger, J.; and Brown: D. J.; J. Chem. Gor. A197i, O4t

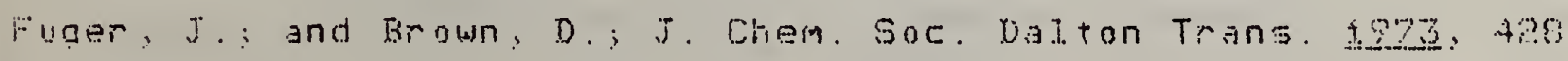


Fuger, I.; and betting, F. L. F The Chemical Thermodunamies of Artin-

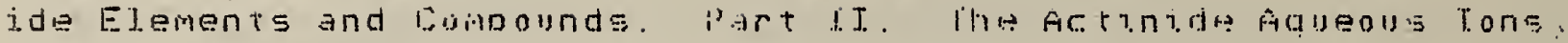

IAEA, Vienna ( $197(i)$

Gagarinskil, Yu. V.; and Khanaes, E. I.; Zhur. Neorg. Khin. 19. 11i $(1767)$

Gaqarinskij, Yu. V. : and Mashirev, U. F.: Rusa. I. Inorg. Ghem. 4: $565(1.759)$

Galkin, M. P.; Veryatin, U. D.; and Smirnos, Yu. U.; Soviet J. At. Energy 王, 257 (1964)

Garvin, D.; Parker, V. E.; Wagman, D. D.; and Evans, W. H. : A Combined Least sums and least squares Approach to the livaluation nf lhermody-

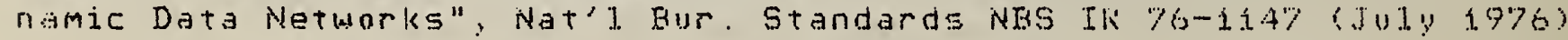

Gaunt, J.; Trans. Faraday Soc. 4 g, fied (1953)

Ginnings, D. C.; and Corruccini, R. J. J. Research Natl. Bur. Sran... dards 39 , $309(194 \%)$

Girdhar, H. L.; and Westrum, E. F., J. Chem. Eng. Data; 13, 53í (1.968)

Glushko, U. P.; ed.; Termicheskie Konstanty Veshchestu. Vol \&, Part

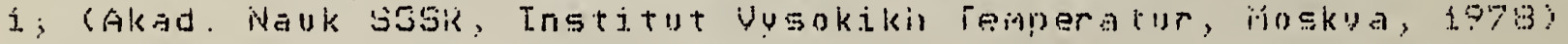

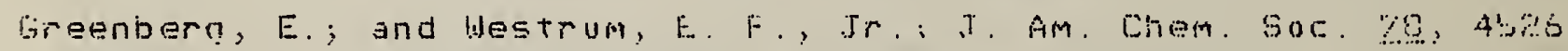
(1956a)

Greenisern, E.; and Westrum, E. F., Jr. : I. Am. Chem. Soc. Zu, 5it4 (1) 1956 b)

Gregory: N.; Report RL-4.6.928 (AUg. 24, 1.95); RL-4.6.936 (0Ct $9 ; 1945) ; R 1-4.6 .940$ (Dec. 13,1945 ), qunted by inacwood, 0 . in

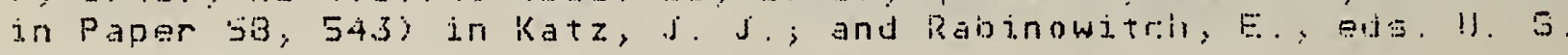

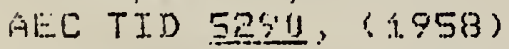

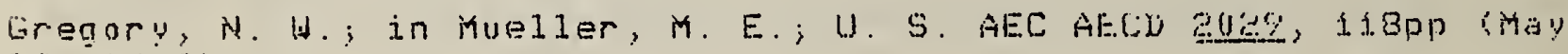
28, 1948$)$

Greqory, N. H.; U. S. AEC AECD 3342, 8pp (AUg is46́)

Gross, P.; Hayman, C.; and Wilson, G. L.; Monatsh. Chem. Iba: 924 (.9.97.1.)

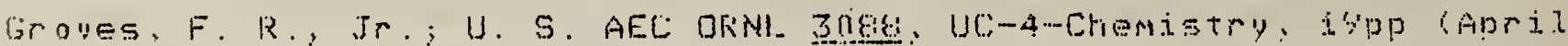
1. 1 , 196í

Gruen, D. M.; and meBeth, R. L.; Inora. Chem. 9. 2605 (1969)

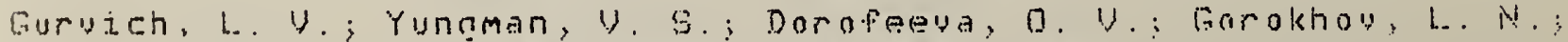

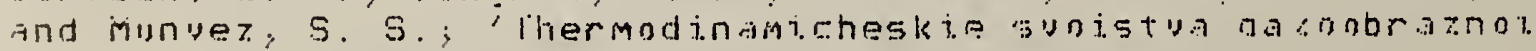
sistemy U-F'. Preprint 1-0018 akademiya Nauk SGSk institut vysokakn lemperatur, 俰sku (iy77) 


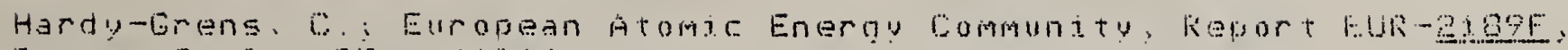
Is 5 ra, Italy, $2000(1964)$

Hayman, H. J. G.; Thermodunamk Symposium in Hedodober Sessan I.

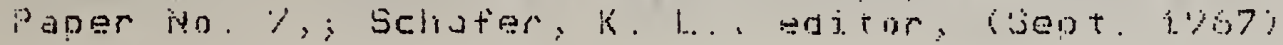

Hearne, J. A.; and white, A. G. T. Chem. Soc. 95y. 206

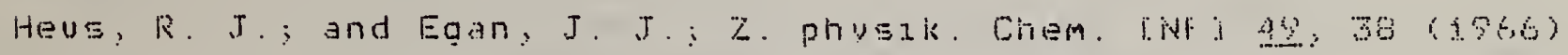

Higgins, T. L.; and Westrum, E. F.; J. Prys. Chem. 65. 830 (996)

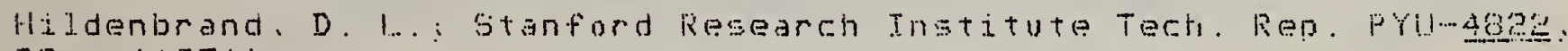
$29 p \mathrm{p}(1976)$

Hoekstra: H. R.; and Sieqel, S.; J. Tnorg. and Nuchear Chem. is. ís (it.

Hoenio: i. L.; J. AM. Ceram. Soc. S4: 391 (19\%1)

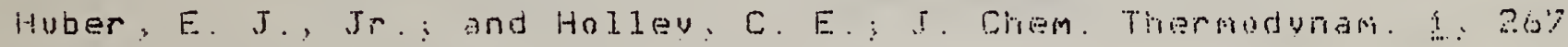
(1969)

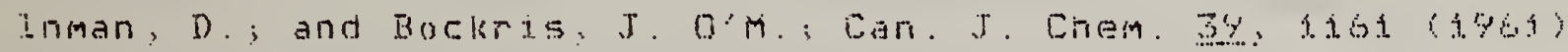

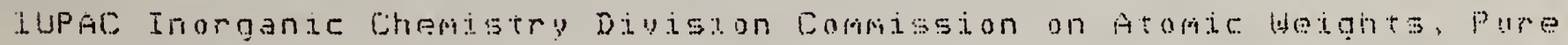
and Applied Chemistry 2 i. 91 igyo)

TANAF Thermochemical. Tables; NSk0s Nho 3\%, U. S. Gouernment Frinting

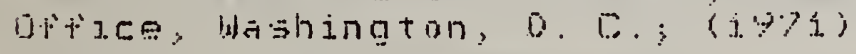

Jenkins, F. A.; and Anderson, O. E.; 1 . Hueller, M. E. : U. S. AE:D ?020, $1180 \mathrm{p}$ (May $23, \pm 348$ )

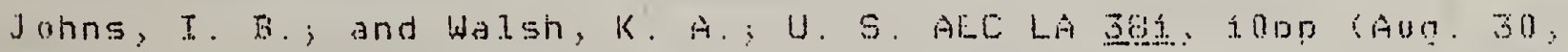
$\{\% 45$ )

Johnson: G. K.; Argonne Nat'? Lab, Private Communacation (Jan is77)

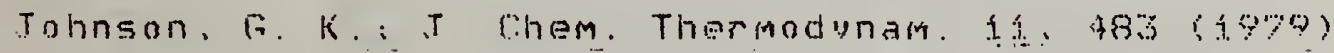

Johnson, G. K.; Smith, P. N.; and Hubbard, W. N.; J. Chem. Thermodunain. $5: 793(1973)$

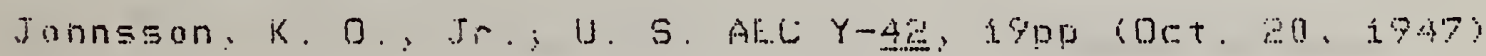

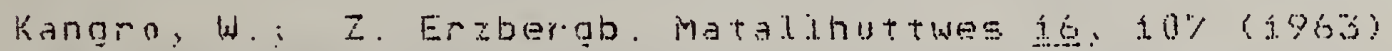

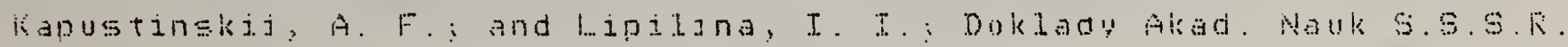

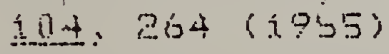

katz, s.; Inoro. Chem. 3. L5?8 (1964)

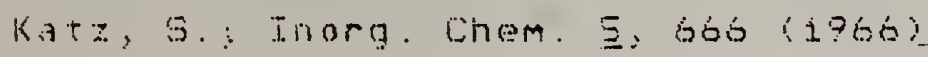


Katz, J. I.; and Rabinowitch, E.; "The Chemistry of Uranium, is ed, idcoratu-ili i. Book Co. (1951)

Kelley, K. K.; Contributions to the data on theoretical metallurny.

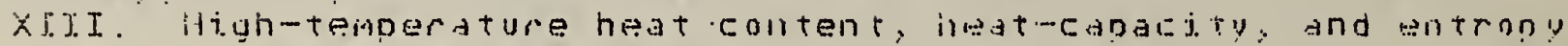
data for the elements and inorganic compounds, U. S. Bur. Mines Bu11. 58ㄹ. 232pp $(1460)$

Kelley, K. K.; and King, E. G.; Contributions to the data ou theoret-

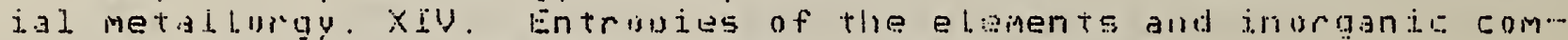
pounds, U. S. Eur. Mines Bull. 592, t49pp (1968)

Khanaey, E. I.; Izuest. Sib. Otd. Akad. Nauk SSski, Ser. Khim. Nauk Q. $123(1968)$

Khanev, F. I.; and Khripin, L. A.; Sopiet Radiochem. is: iso (j970); English translation of Radiokhimiya fie, $1 \% 8$ (1.9\%(0)

Kiquoshi: K.; Nippon Koqaku Zasshi Z2: 57 (i95t)

King, E. G.; and Chrietensen, A. U.; U. S. Bur. Mines, Rept. Inuest. $7709,4 p p(i 96.1)$

Knacke, D.; Lossmann, G.; and muller, F.: Z. anorn. U. allagm. Chem. 371․ $32,(1969)$

Knacke, 0.; Muller, R.; and von Rensen: E. V.; Z. whysik. Chem. E0: $9.1 \quad(1972)$

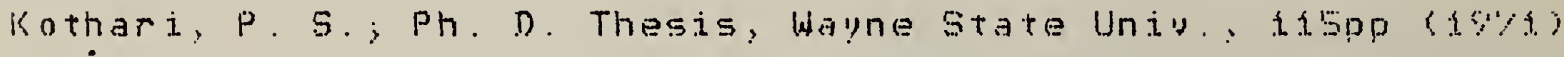

Krestoy, G. A. ; 'Termokhimina Soedinenit Redkozemel'nykh "Aktinoid". nykh EJ.emenion' inskua, Atomidat, (j.972)

Krohn, E. J.; Person: W. E.; and Qverend. J.; J. Chem. Phys. 6s.969 $(1976)$

Kudryashou, U. L.; Sughobova, 1. G.; and Chirkst, D. E. : Radiokhimaya 르. 366 (19\%8b)

Kudryashou, U. L.; Sugloboua, I. G.; and Chirkst, O. E.; Radiokinimiya 르: $373(39 \%$ a)

Kuthlman; MCiN $118(1.9483)$

Lanaer, G.; and Blankenship, F. F.; J. Inarg. and Nuclear Chem. IA 26 (1960)

Lipilina, I. I.; and Samoilou, O. Ya.; Doklady Akad. Nauk SGSk 9y: 9y (1.954)

L.tewellyn; D. R.: T. Chem. Soc. 195: 


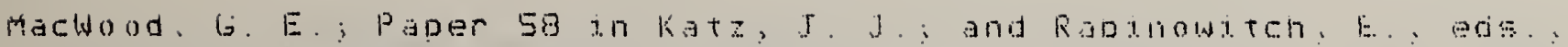

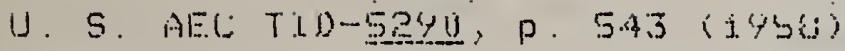

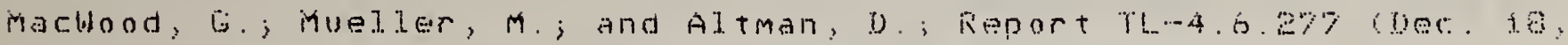
2944 ;

Malm, J. G.; Selig, H.; and sieqel, S.; Inorg. Chem. 5: 130 (1960)

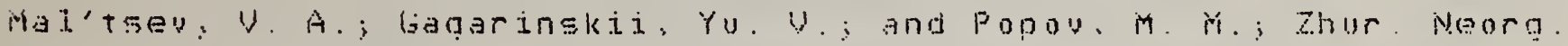
khim. 5. 228 (1960)

Markin, T. L.; tiones: R. J.: and Wheeler, U. J.; Froc Brit. Coram. Soc. S. 51 (1967)

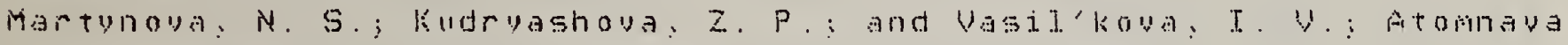
Energiya es: 226 (i968)

Hasi, J.F.; J. Chein. Phys. 1\%, 755 (1949)

Maslow, P. G.; zhur. Hearg. Khtm. 9. 20\%6 (1964)

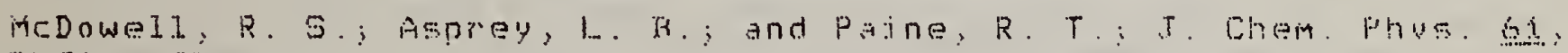
$37.71(19 \%+4)$

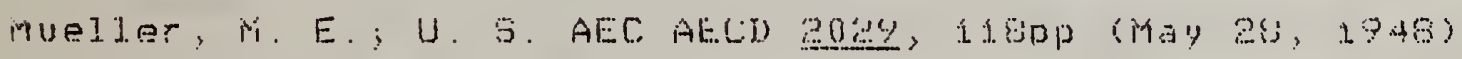

muknametshina, Z. B. : Selazney, U. P. s Suponatskil, Yu. L. : Badrou:

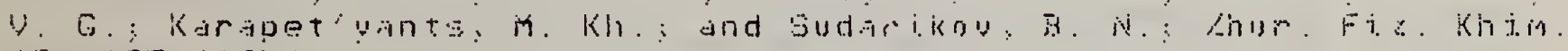
4. $495(19 \% 4$ a)

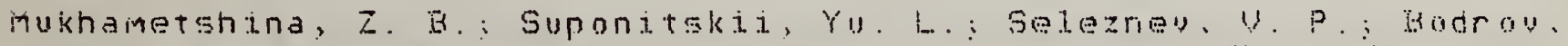

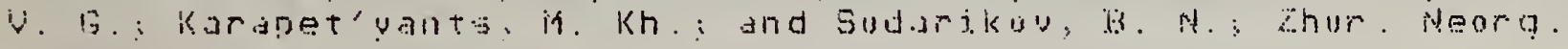

Khim. 19. $4 \% 4$ (1.9\%4b)

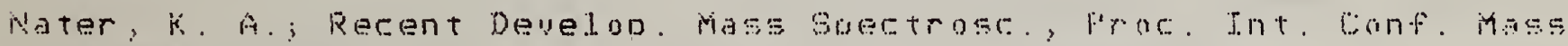
opectrose. 1960; is

Uetting, F. L. : Rand, if. H. : and Ackerpann, R. J. : The Chemeal Tilermodynainjes of Actinjue Elements and bompounds: Par 1 . The hetin. ide Elements, IAEA, Vienria (IO\%)

O'Hare: P. A. G.: Eoerio, J. : and Hoekstra, H. R.: J. Chem. Thermodunam. ?. 945 (19\%)

QHare, F. A. G.: and Hoekstra: H. R. : I. Chem. Thermodumam. 9 : 769 (1973)

UHare: P. A. G.; and Hoekstra, H. P.; i. Chom. Thermodynam. (.1974)

0.Hare, P. A. G.: and Johnson, G. K. : Frivate Cormundeation, fir onne

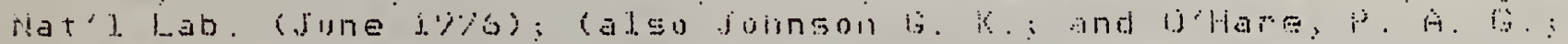
J. Chem. Thermoduriam. if : $57 \%$ (2973)? 
Q'Hare, P. A. G.; Settle, J. L. Feder, H. M. ; and Hubbard. W. M.;

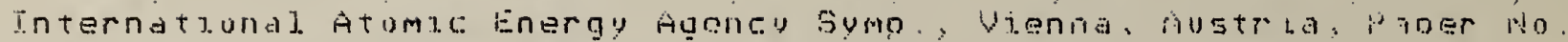
xit $98 / 4$ is: ipp isept. 1967 )

O'Hare, P. A. G.; Shinn, W. A.; Mrazek, F. C.: and Martin, A. E.; I. Chem. Thermoriynam. 4. 40 t (19\%)

Qliver, G. D. ; milton, H. T. : and Grisard, J. W.: J. Am. Chem, Sor. 고.․․․ $283(1953)$

Ostoorne, D. W.; Flotow, H. F.: Fried, S. M.; and halm, J. G.; J. Chem. F'hys. in $1463(19 \% 4)$

Deborne, D. W.; Flotow, H. E.: Fried, i. i.; and iblin, J. G. I. Chem. Phys. 6.5. $46.53(19 \% 5)$

Qseborne: D. W.; Westrum, E. F.: and Lonr. H. R.; J. Am. Chem. Soc.

7.7. $273 \%(.955)$

Parker, U. B.; letter to T. Fuger, June $13,49 \%$

Parker, U. B.; NAS Interim, Thermochem. Props. U Combounds [oid $2 \%$ Hase] and [LUDATA base], (April. i. i.\%aj)

Parker, U. B. "An Anadusis and Tnterbretation of allt" UFb "MemoranGUM for IAEA Authors, (BCt. is, 1976 )

Farker, U. B.; Wagman, D. D.; and Garyin, D.; 'Sejected Thermohem.. 1Cal Data Cumpatible with LOUAla Recinmilundations', Natl. Bur.

Standards NAS IR $75-968$ (1.7\%)

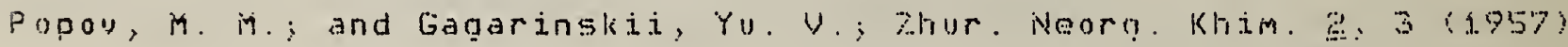

Papou, in. if. : Galchenka, G. L. ; and Senin, M. D. : zhur. Noarq. Khin. I. $124 . \quad(1959 a)$

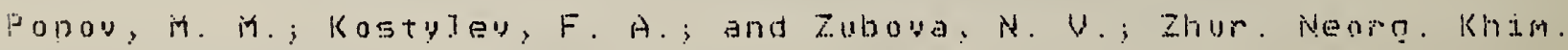
4. $170(3$ (1959)

Popon, M. M.; Kostyley, F. A. : and Karpova, T. F. Z Zhur. Nenrq. Khim. ?., 9 (isb7)

Prins, G.; Reactor Cent. Ned. Rept. No. 186, Lisnp (1973)

Prins, G.; Cordfunke: E.; Ouweltjes, W. Priugte Communication (Fob. 1773)

Rand, 计. H. : Ackermann, R. J.j Gronundo, F. Detting, F. L. : and

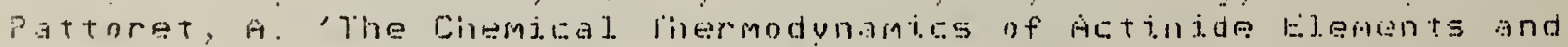
compounds'. Part XT. The Actinide oxides. IAEA, Vienna ito be publisned;

Rand, if. H.; and Kubaschewski: D.: The Thermochemical Properties of

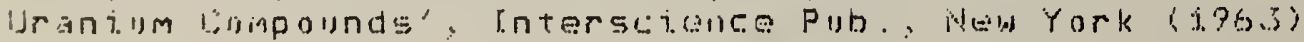


Rasejnd, F. D.; Wagman, D. D. Fuane, W. II, kevine, S.; and jafre.

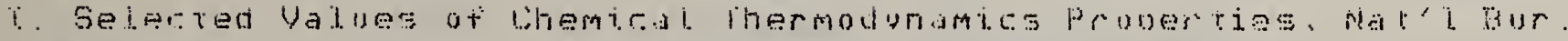
Standards, Cire Sug. U. S. Cout. Printing Office, wish. Ö. C. (iggis)

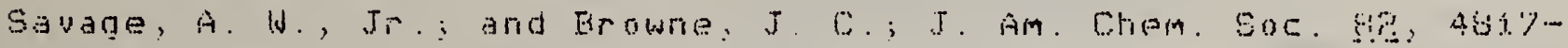
$4621(1960)$

Seip, H. H. Acta Chem. Scand. 12. 1955 (1965)

Settle, J. L.; Feder, H. H. and Hubbard, W. M.; I. Phys. Chem. G\%: $1392(1963)$

Shchukarey, S. A. : Vasil"koya: I. U.; and Efimou, A. I. : zhur. Noorg.

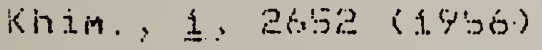

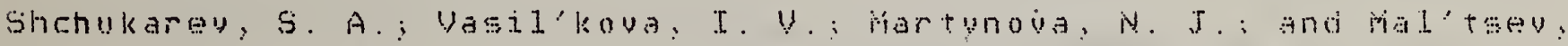

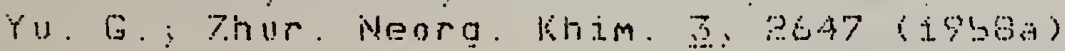

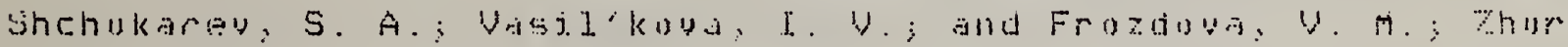
Neora. Khim. 3. 26́: (19581)

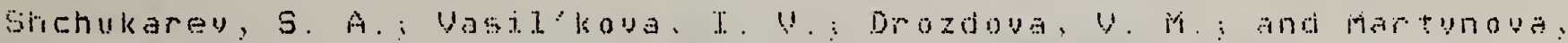

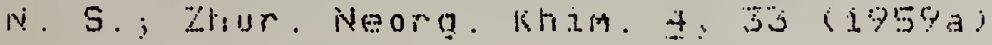

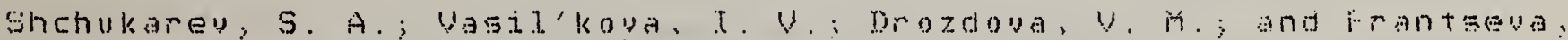
K. E.; Zhur. Neora. Khim. 4, 39 (1959b)

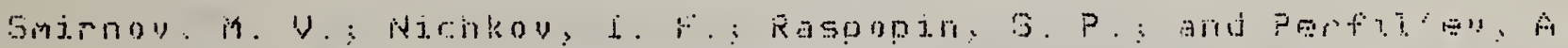

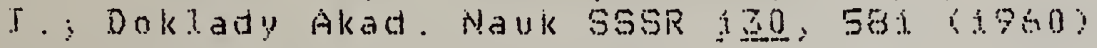

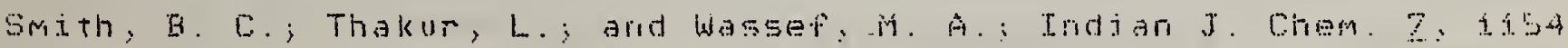
(.969)

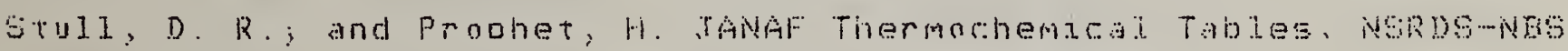
37 (.Jung $1.9 \%$ í.)

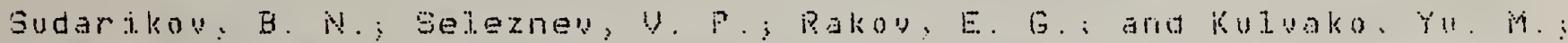

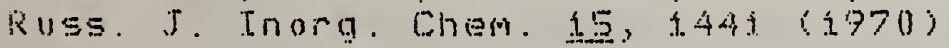

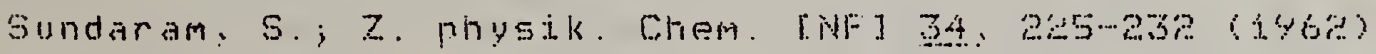

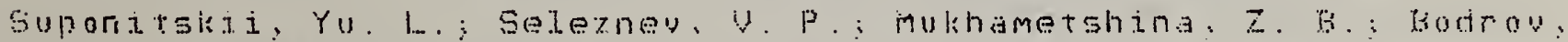

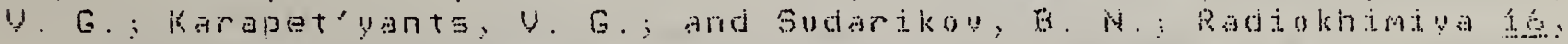
$08(1974)$

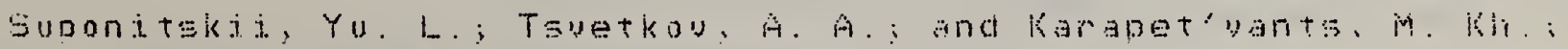
Ruse. J. Hhys. Chem. 45, 556 (i)\%,

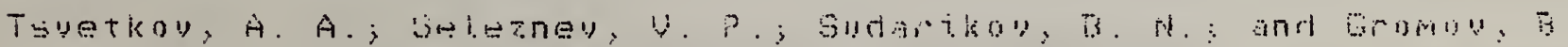

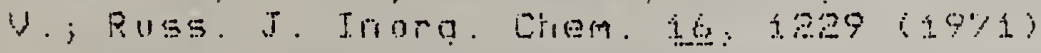

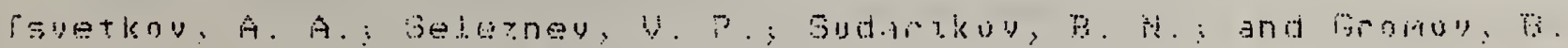

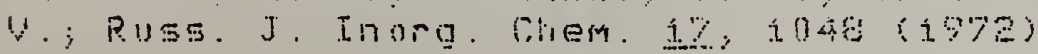


Tsuetkov. A. A.; Seleznev, U. P.; Sudarikov, B. N.; and Gromou, E. 1) ; Russ. I. Inorg. Chem. Lis. 5 (1973)

Tumanov, Y. N.; Ruse. J. Inora. Chem. 13, 782 (tsb8)

Tyeekrem, J. O.; and Chandrasekharaiah. M. S.; T. Elertrocheri. Sor. 1. $15,102.4(1968)$

Udouenko, Y. in.; Romanoy, G. A.; and Gheherbakoy, U. A.; Radiokhimiva 5. $531(1063)$

Udovenko, V. M.; Rorianov, G. A.; and Solntseva, L. V.; Radiokhimiya Q. $727(1967)$

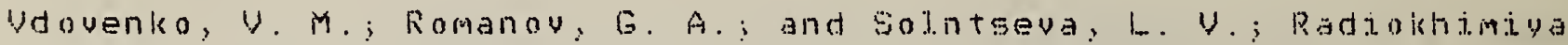
1. $466(1969)$

Wovenko, U. M.; Komanou, G. A.; Malinin, G. U.; and Sointseya, L. V.; Soujet Radiochem. I2, 7 is (1970a)

Udovenko, U. M. K Komanow, G. A.; and Solntseva, L. V. ; Soviet Radiochem. 1 e, 730 (19\%(0)

Udovenko, U. i. ; Suglobova, T. G; and Chiokst, D. F.; Radiokhumiya 15. (1) $50(1973)$

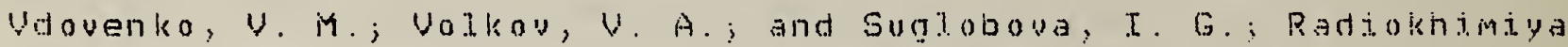
16. $363.3(1974)$

Vidauskii, L. in.; Lyakhova, N. I.; and Ippolitoua, E. A. : Zhur.

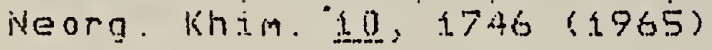

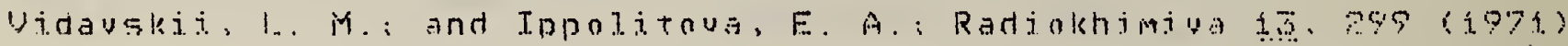

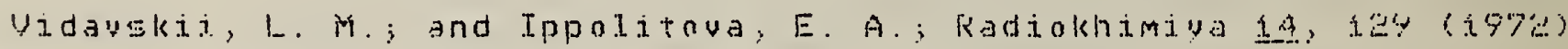

Wacker, P. F.; and Cheney, K. K.; J. Kes. Nath. Gur. Standards ziy. $317(194 \%)$

Wagan, D. D. et al, NES Technical 270

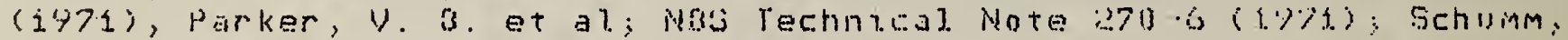
R. H., et al ; NaS Technical Note 270-" (x)y3); U. G. Government Printing Dtrice (Washington. D.C.)

Wagman, D. D.; Schumm, R. H.; and Parker, U. E.; 'A Computer-Assisted

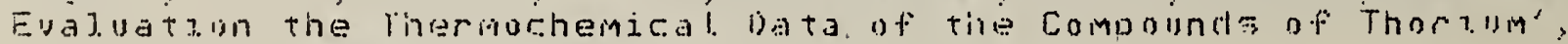
Wat'l Tur. Standards NISIR 77-t300 (AUQ. \{977)

Weinstack, B.; and Crist, R. H.; J. Chem. Phys. 1.5, 436 (is4s) westrum, E. F.; and Gronwald, F.; J. Am. Chem. Sor. 31. d17\%; 1959$)$ Hestrum, E. F.: IAEA Symposium on Thermodynamics, Vienna: Aistria II, 497 (1.960) 
Westrum, E. F.; and Huntzicker, I. T.; T. Chem. Thermounam. 3 : bs (1.971)

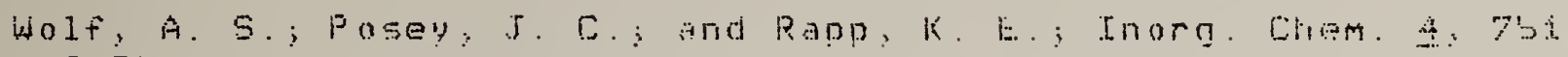
(1955)

Young, H. S.; and Grady, H. F.; Paper pe in Katz, J. I. : and Rabin-

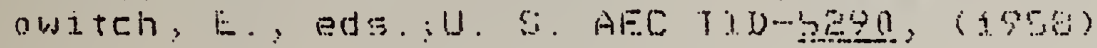

Zunoy, K. F.; 'Heats of Formatzon of Lower Actinide Flunrades from

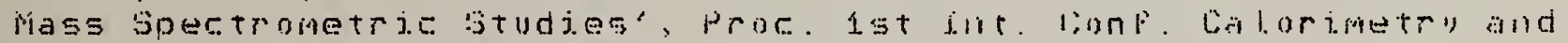
Thermodynamics, Warsaw $\mathrm{p}$. 493: (Aug. 3i-Sept. 4, 1969) 

V. Appendix: Thermal Functions for Some Uranium-Halogen Containing Compounds 



\begin{tabular}{|c|c|c|c|c|}
\hline \multirow[b]{2}{*}{$\mathrm{T} \mathrm{K}$} & \multicolumn{3}{|c|}{ UF (g) } & \multirow[b]{2}{*}{$\begin{array}{c}-\left(\mathrm{G}-\mathrm{H}_{298}\right) / \mathrm{T} \\
\mathrm{cal} / \mathrm{mol} \cdot \mathrm{K}\end{array}$} \\
\hline & $\begin{array}{c}\mathrm{Cp}_{\mathrm{p}} \\
\mathrm{cal} / \mathrm{mol} \cdot \mathrm{K}\end{array}$ & $\begin{array}{c}\mathrm{H}-\mathrm{H}_{0} \\
\mathrm{ca} 1 / \mathrm{mol}\end{array}$ & $\begin{array}{c}\mathrm{S}^{\circ} \\
\mathrm{ca} \mathrm{I} / \mathrm{mol} \cdot \mathrm{K}\end{array}$ & \\
\hline $\begin{array}{l}100 \\
200 \\
298.15 \\
300 \\
500 \\
1000 \\
1500 \\
2000\end{array}$ & $\begin{array}{r}7.01 \\
7.99 \\
9.04 \\
9.05 \\
10.11 \\
10.76 \\
10.93 \\
11.01\end{array}$ & $\begin{array}{r}696 \\
1439 \\
2278 \\
2294 \\
4229 \\
9492 \\
14919 \\
20405\end{array}$ & $\begin{array}{l}51.83 \\
56.94 \\
60.34 \\
60.39 \\
65.31 \\
72.58 \\
76.98 \\
80.14\end{array}$ & $\begin{array}{l}67.65 \\
61.14 \\
60.34 \\
60.34 \\
61.41 \\
65.37 \\
68.55 \\
71.07\end{array}$ \\
\hline & & $\mathrm{UF}_{2}(\mathrm{~g})$ & & \\
\hline $\begin{array}{l}100 \\
200 \\
298.15 \\
300 \\
500 \\
1000 \\
1500 \\
2000\end{array}$ & $\begin{array}{r}9.48 \\
11.93 \\
16.00 \\
16.06 \\
18.33 \\
16.83 \\
17.35 \\
18.10\end{array}$ & $\begin{array}{r}858 \\
1908 \\
3279 \\
3309 \\
6887 \\
15552 \\
24060 \\
32937\end{array}$ & $\begin{array}{r}58.48 \\
65.66 \\
71.18 \\
71.28 \\
80.37 \\
92.45 \\
99.34 \\
104.44\end{array}$ & $\begin{array}{l}82.69 \\
72.52 \\
71.18 \\
71.18 \\
73.16 \\
80.18 \\
85.49 \\
89.62\end{array}$ \\
\hline & & $U F_{3}(g)$ & & \\
\hline 100 & 12.61 & 1009 & 63.11 & 93.46 \\
\hline 200 & 15.41 & 2411 & 72.72 & 80.89 \\
\hline 298.15 & 17.76 & 4044 & 79.33 & 79.33 \\
\hline 300 & 17.79 & 4077 & 79.44 & 79.33 \\
\hline 500 & 20.27 & 7929 & 89.23 & 81.46 \\
\hline 1000 & 21.49 & 18457 & 103.78 & 89.36 \\
\hline 1500 & 22.05 & 29348 & 112.60 & 95.74 \\
\hline 2000 & 22.58 & 40504 & 119.02 & 100.78 \\
\hline
\end{tabular}




\begin{tabular}{rrrrr} 
& \multicolumn{5}{c}{$\mathrm{UF}_{3}(\mathrm{c})$} \\
& $\mathrm{Cp}$ & $\mathrm{H}-\mathrm{H}_{298}$ & $\mathrm{~S}^{\circ}$ & $-\left(\mathrm{G}-\mathrm{H}_{298}\right) / \mathrm{T}$ \\
& $\mathrm{cal} / \mathrm{mol} \cdot \mathrm{K}$ & $\mathrm{cal} / \mathrm{mol}$ & $\mathrm{ca} 1 / \mathrm{mol} \cdot \mathrm{K}$ & $\mathrm{ca} 1 / \mathrm{mol} \cdot \mathrm{K}$ \\
298.15 & 23.38 & 0 & 30 & 30 \\
300 & 23.39 & 43. & 30.145 & 30. \\
400 & 24.12 & 2419. & 36.974 & 30.927 \\
500 & 24.85 & 4867. & 42.434 & 32.700 \\
600 & 25.58 & 7389. & 47.029 & 34.715 \\
700 & 26.31 & 9983. & 51.027 & 36.766 \\
800 & 27.04 & 12651. & 54.588 & 38.775 \\
900 & 27.77 & 15391. & 57.815 & 40.714 \\
1000 & 28.5 & 18205. & 60.779 & 42.574
\end{tabular}




\begin{tabular}{|c|c|c|c|c|}
\hline \multirow[b]{2}{*}{$\mathrm{T} \mathrm{K}$} & \multicolumn{3}{|c|}{$U F_{4}(g)$} & \multirow[b]{2}{*}{$\begin{array}{r}-\left(\mathrm{G}-\mathrm{H}_{298}\right) / \mathrm{T}^{\mathrm{a}} \\
\mathrm{cal} / \mathrm{mol} \cdot \mathrm{K}\end{array}$} \\
\hline & $\begin{array}{c}\mathrm{CP}_{\mathrm{P}} \\
\mathrm{cal} / \mathrm{mol} \cdot \mathrm{K}\end{array}$ & $\begin{array}{l}\mathrm{H}-\mathrm{H}_{0} \\
\mathrm{ca} 1 / \mathrm{mol}\end{array}$ & $\begin{array}{c}\mathrm{S}^{\mathrm{a}^{a}} \\
\mathrm{ca} \mathrm{l} / \mathrm{mol} \cdot \mathrm{K}\end{array}$ & \\
\hline 298.15 & 21.815 & 4764 & $80.176+8.2$ & $80.176+8.2$ \\
\hline 300 & 21.852 & 4804 & $80.311+8.2$ & $80.177+8.2$ \\
\hline 400 & 23.304 & 7070 & $86.818+8.2$ & $81.054+8.2$ \\
\hline 500 & 24.114 & 9434 & $92.113+8.2$ & $82.753+8.2$ \\
\hline 600 & 24.598 & 11882 & $96.556+0.2$ & $84.693+8.2$ \\
\hline 700 & 24.906 & 14358 & $100.373+8.2$ & $86.667+8.2$ \\
\hline 800 & 25.114 & 16860 & $103.713+8.2$ & $88.593+8.2$ \\
\hline 900 & 25.259 & 19379 & $106.680+8.2$ & $90.441+8.2$ \\
\hline 1000 & 25.365 & 21910 & $109.347+8.2$ & $92.201+8.2$ \\
\hline 1100 & 25.444 & 24451 & $111.768+8.2$ & $93.871+8.2$ \\
\hline 1200 & 25.505 & 26998 & $113.985+8.2$ & $95.456+8.2$ \\
\hline 1300 & 25.553 & 29551 & $116.028+8.2$ & $96.961+8.2$ \\
\hline 1400 & 25.591 & 32109 & $117.923+8.2$ & $98.392+8.2$ \\
\hline 1500 & 25.622 & 34669 & $119.690+8.2$ & $99.753+8.2$ \\
\hline & & (g) & & \\
\hline 298.15 & 26.222 & 5597 & $90.055+3.0$ & $90.055+3.0$ \\
\hline 300 & 26.270 & 5646 & $90.218+3.0$ & $90.056+3.0$ \\
\hline 400 & 28.222 & 8380 & $98.069+3.0$ & $91.113+3.0$ \\
\hline 500 & 29.342 & 11263 & $104.498+3.0$ & $93.167+3.0$ \\
\hline 600 & 30.022 & 14233 & $109.913+3.0$ & $95.519+3.0$ \\
\hline 700 & 30.460 & 17259 & $114.576+3.0$ & $97.916+3.0$ \\
\hline 800 & 30.756 & 20321 & $118.664+3.0$ & $100.259+3.0$ \\
\hline 900 & 30.965 & 23407 & $122.298+3.0$ & $102.510+3.0$ \\
\hline 1000 & 31.117 & 26512 & $125.570+3.0$ & $104.655+3.0$ \\
\hline 1100 & 31.231 & 29629 & $128.541+3.0$ & $106.693+3.0$ \\
\hline 1200 & 31.319 & 32757 & $131.262+3.0$ & $108.629+3.0$ \\
\hline 1300 & 31.388 & 35892 & $133.772+3.0$ & $110.468+3.0$ \\
\hline 1400 & 31.443 & 39034 & $136.100+3.0$ & $112.217+3.0$ \\
\hline 1500 & 31.487 & 42181 & $138.271+3.0$ & $113.882+3.0$ \\
\hline
\end{tabular}

$\mathrm{S}$ and $-\left(\mathrm{G}-\mathrm{H}_{298}\right) / \mathrm{T}$ values for $\mathrm{UF}_{4}(\mathrm{~g})$ are increased by $8.2 \mathrm{cal} / \mathrm{mol} \cdot \mathrm{K}$ to be consistent with equilibrium data; similarly $3.0 \mathrm{cal} / \mathrm{mol} \cdot \mathrm{K}$ are added for $\mathrm{UF}_{5}(\mathrm{~g})$. 


\begin{tabular}{|c|c|c|c|c|}
\hline \multirow[b]{2}{*}{$T K$} & \multicolumn{3}{|c|}{$\mathrm{UF}_{6}(\mathrm{~g})$} & \multirow[b]{2}{*}{$\begin{array}{c}-\left(\mathrm{G}-\mathrm{H}_{298}\right) / \mathrm{T} \\
\mathrm{cal} / \mathrm{mol} \cdot \mathrm{K}\end{array}$} \\
\hline & $\begin{array}{c}\mathrm{Cp}_{\mathrm{p}} \\
\mathrm{cal} / \mathrm{mol} \cdot \mathrm{K}\end{array}$ & $\begin{array}{l}\mathrm{H}-\mathrm{H}_{0} \\
\mathrm{ca} 1 / \mathrm{mol}\end{array}$ & $\begin{array}{c}\mathrm{S}^{\circ} \\
\mathrm{ca} 1 / \mathrm{mol} \cdot \mathrm{K}\end{array}$ & \\
\hline 298.15 & 30.985 & 6384.4 & 90.233 & 90.233 \\
\hline 300 & 31.044 & 6441.7 & 90.425 & 90.233 \\
\hline ¿̇̃o & 33.436 & 9677.4 & 99.717 & 91.484 \\
\hline 500 & 34.797 & 13095.1 & 107.337 & 93.916 \\
\hline 600 & 35.620 & 16619.1 & 113.760 & 96.702 \\
\hline 700 & 36.149 & 20209.4 & 119.293 & 99.543 \\
\hline 800 & 36.506 & 23843.2 & 124.145 & 102.322 \\
\hline 900 & 36.757 & 27507.0 & 128.460 & 104.991 \\
\hline 1000 & 36.941 & 31192.4 & 132.343 & 107.535 \\
\hline 1100 & 37.078 & 34893.7 & 135.871 & 109.953 \\
\hline 1200 & 37.184 & 38607.0 & 139.102 & 112.249 \\
\hline 1300 & 37.267 & 42329.8 & 142.081 & 114.431 \\
\hline 1400 & 37.333 & 46059.9 & 144.846 & 116.506 \\
\hline 1500 & 37.387 & 49796.0 & 147.423 & 118.482 \\
\hline 1600 & 37.431 & 53537.0 & 149.838 & 120.367 \\
\hline 1700 & 37.468 & 57282.0 & 152.108 & 122.168 \\
\hline 1800 & 37.499 & 61030.3 & 154.251 & 123.892 \\
\hline 1900 & 37.525 & 64781.5 & 156.279 & 125.543 \\
\hline 2000 & 37.547 & 68535.1 & 158.204 & 127.129 \\
\hline
\end{tabular}




\begin{tabular}{|c|c|c|c|c|}
\hline \multirow[b]{2}{*}{$\mathrm{T} \mathrm{K}$} & \multicolumn{3}{|c|}{$\mathrm{UBr}_{3}(\mathrm{c})$} & \multirow[b]{2}{*}{$\begin{array}{r}-\left(\mathrm{G}-\mathrm{H}_{298}\right) / \mathrm{T} \\
\mathrm{cal} / \mathrm{mol} \cdot \mathrm{K}\end{array}$} \\
\hline & $\begin{array}{c}\mathrm{Cp}_{\mathrm{p}} \\
\mathrm{cal} / \mathrm{mol} \cdot \mathrm{K}\end{array}$ & $\begin{array}{l}\mathrm{H}-\mathrm{H}_{298} \\
\mathrm{ca} 1 / \mathrm{mol}\end{array}$ & $\begin{array}{c}\mathrm{S}^{\circ} \\
\mathrm{ca} 1 / \mathrm{mol} \cdot \mathrm{K}\end{array}$ & \\
\hline 298.15 & 25.98 & 0 . & 46.00 & 46.00 \\
\hline 300 & 25.99 & 48. & 46.16 & 46.00 \\
\hline 400 & 26.62 & $25>0$. & 53.72 & 47.03 \\
\hline 500 & 27.25 & 5372. & 59.73 & 48.99 \\
\hline 600 & 27.88 & 8129. & 64.76 & 51.21 \\
\hline 700 & 28.51 & 10948 & 69.10 & 53.46 \\
\hline 800 & 29.14 & 13831. & 72.95 & 55.66 \\
\hline 900 & 29.77 & 16776 . & 76.42 & 57.78 \\
\hline 1000 & 30.40 & 19785. & 79.59 & 59.80 \\
\hline
\end{tabular}

$$
\mathrm{UBr}_{4}(c, 1)
$$

$\mathrm{T} \mathrm{K}$

298.15

300

400

500

600

700

792

792

800

900

1000

1040
$\mathrm{C}_{\mathrm{p}}$

$\mathrm{cal} / \mathrm{mol} \cdot \mathrm{K}$

30.62

30.63

31.34

32.05

32.76

33.47

34.12

41.00

41.00

41.00

41.00

41.00

$$
\mathrm{H}-\mathrm{H}_{298}
$$

ca 1/mol

0.

57.

3155 .

6325.

9565 .

12877.

15986 .

27586 .

27914 .

32014 .

36114 .

37754 .

$\begin{array}{cc}\mathrm{S}^{\circ} & -\left(\mathrm{G}-\mathrm{H}_{298}\right) / \mathrm{T} \\ \mathrm{cal} / \mathrm{mol} \cdot \mathrm{K} & \mathrm{ca} 1 / \mathrm{mol} \cdot \mathrm{K} \\ 57.00 & 57.00 \\ 57.19 & 57.00 \\ 66.10 & 58.21 \\ 73.17 & 60.52 \\ 79.07 & 63.13 \\ 84.18 & 65.78 \\ 88.35 & 68.17 \\ 103.00 & 68.17 \\ 103.41 & 68.52 \\ 108.24 & 72.67 \\ 112.56 & 76.44 \\ 114.17 & 77.86\end{array}$


T K

298.15

300

400

500

600

700

800
$\mathrm{Cp}_{\mathrm{p}}$

$\mathrm{cal} / \mathrm{mol} \cdot \mathrm{K}$

26.83

26.84

27.42

28.00

28.58

29.16

29.74

$$
\mathrm{UI}_{3}(\mathrm{c})
$$

$$
\mathrm{H}-\mathrm{H}_{298}
$$

ca 1/mol

0.

50.

2763.

5534.

8363.

11250.

14195 .

$S^{\circ}$
$\mathrm{ca} 1 / \mathrm{mol} \cdot \mathrm{K}$
53.00
53.17
60.97
67.15
72.30
76.75
80.68

$-\left(\mathrm{G}-\mathrm{H}_{298}\right) / \mathrm{T}$

ca $1 / \mathrm{mol} \cdot \mathrm{K}$

53.00

53.00

54.06

56.08

58.37

60.68

62.94
$U I_{4}(c, 1)$

$T K$

298.15

300

400

500

600

700

779

779

800

870
$\mathrm{Cp}_{\mathrm{p}}$

$\mathrm{cal} / \mathrm{mol} \cdot \mathrm{K}$

30.20

30.27

32.80

34.10

34.92

35.50

35.88

39.60

39.60

39.60
$\mathrm{H}-\mathrm{H}_{298}$

ca $1 / \mathrm{mol}$

0.

56.

3226 .

6577 .

10031.

13553.

16373.

25573.

26404.

29176.

$\begin{array}{cc}\mathrm{S}^{\circ} & -\left(\mathrm{G}-\mathrm{H}_{298}\right) / \mathrm{T} \\ \mathrm{ca} 1 / \mathrm{mol} \cdot \mathrm{K} & \mathrm{ca} 1 / \mathrm{mol} \cdot \mathrm{K} \\ 63.00 & 63.00 \\ 63.19 & 63.00 \\ 72.29 & 64.22 \\ 79.76 & 66.61 \\ 86.06 & 69.34 \\ 91.48 & 72.12 \\ 95.30 & 74.28 \\ 107.11 & 74.28 \\ 108.16 & 75.16 \\ 111.49 & 77.95\end{array}$


NBS-IISA $= \pm 2.3-3$

\begin{tabular}{|c|c|c|c|}
\hline 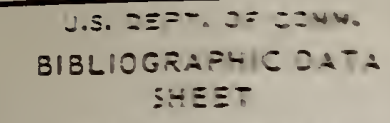 & 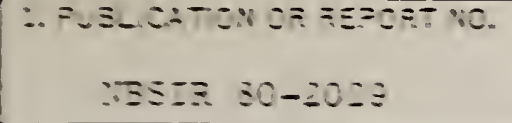 & 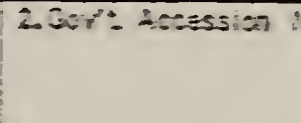 & 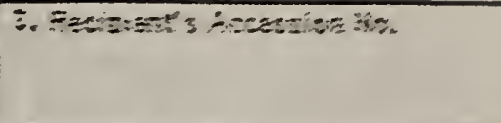 \\
\hline \multirow{2}{*}{\multicolumn{3}{|c|}{ 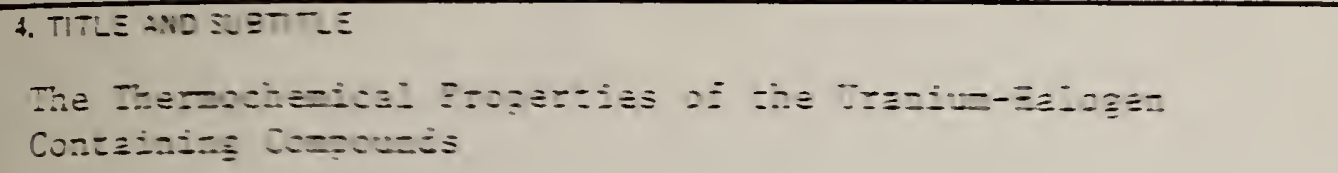 }} & 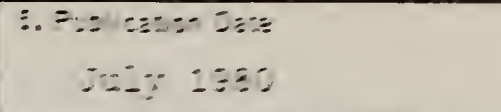 \\
\hline & & & 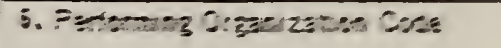 \\
\hline \multicolumn{3}{|l|}{ 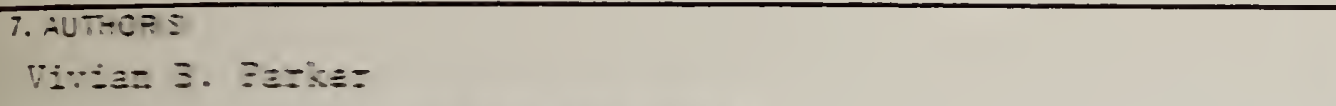 } & 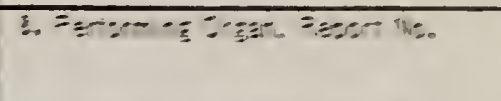 \\
\hline \multicolumn{3}{|c|}{ 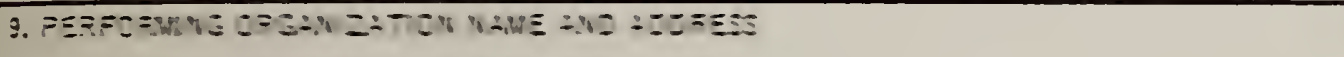 } & 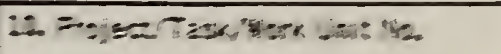 \\
\hline \multicolumn{3}{|c|}{ 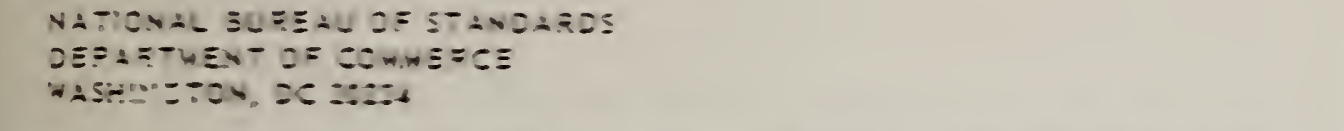 } & $\because 2$ :z-Zac: Grare "K. \\
\hline \multirow{2}{*}{\multicolumn{3}{|c|}{ 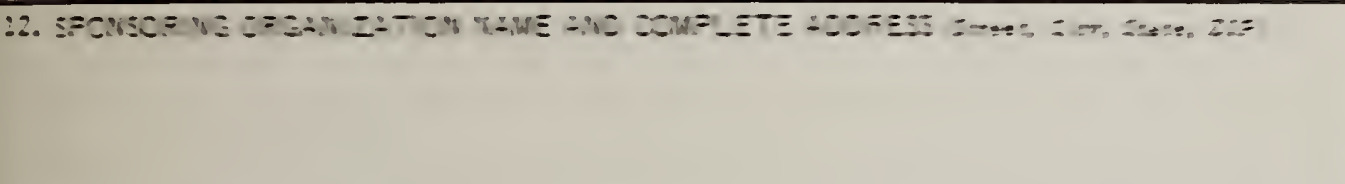 }} & 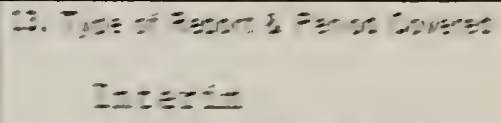 \\
\hline & & & 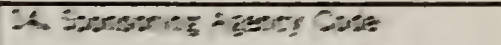 \\
\hline
\end{tabular}

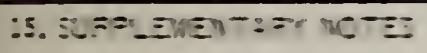

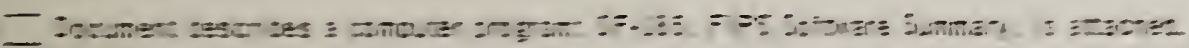

:. -

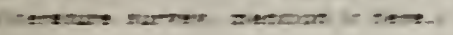

¿

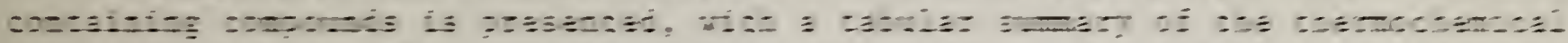

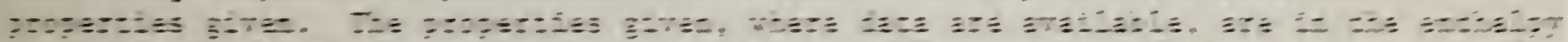

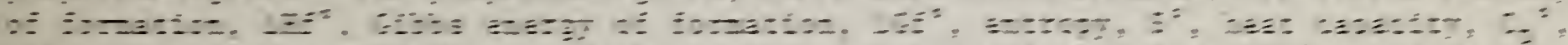

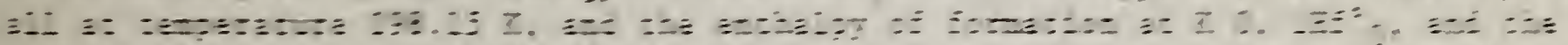

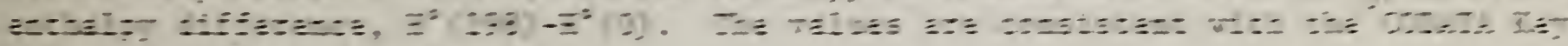

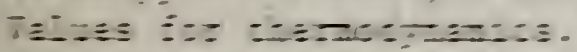

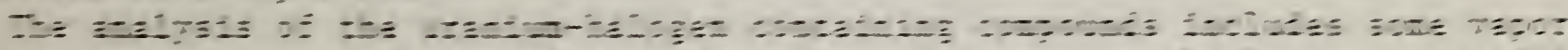

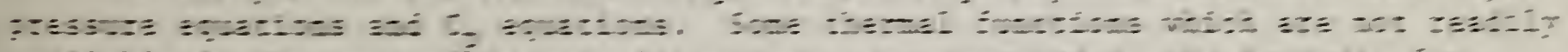

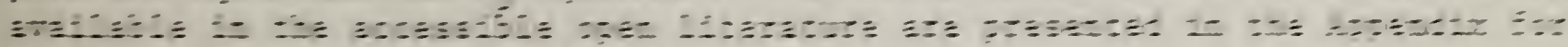

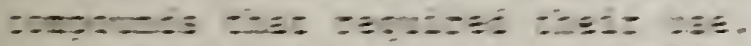

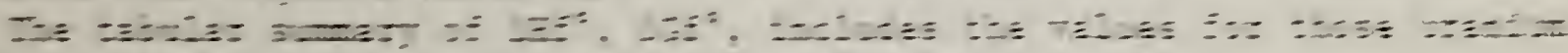

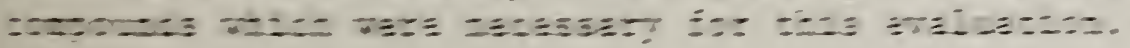

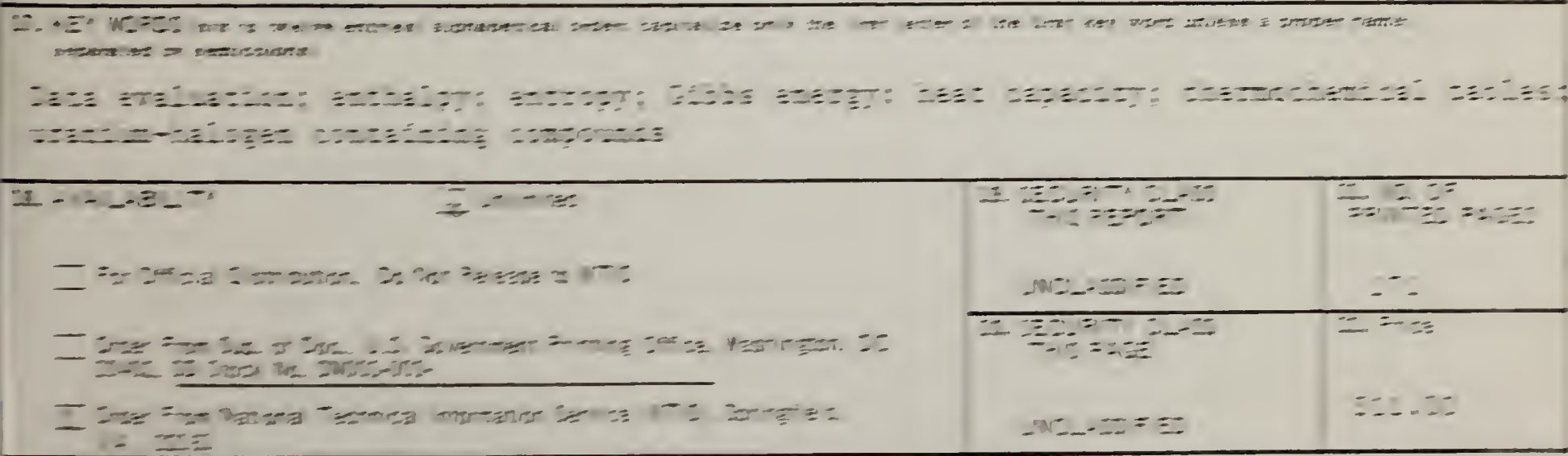




